

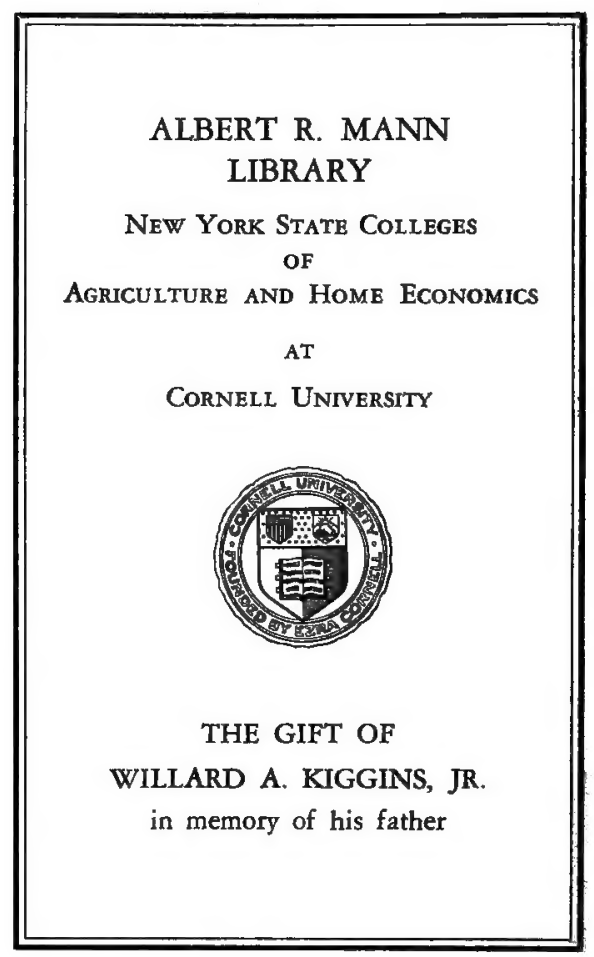




\section{Cornell University Library}

\section{SH 463.H721}

The big game fishes of the United States

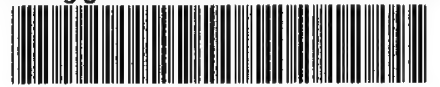

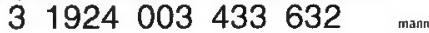




\section{Cornell University Library}

The original of this book is in the Cornell University Library.

There are no known copyright restrictions in the United States on the use of the text.

http://www.archive.org/details/cu31924003433632 
THE AMERICAN SPORTSMAN'S LIBRARY EDITED $B Y$

CASPAR WHITNEY

\section{THE BIG GAME FISHES OF THE UNITED STATES}


Thes 



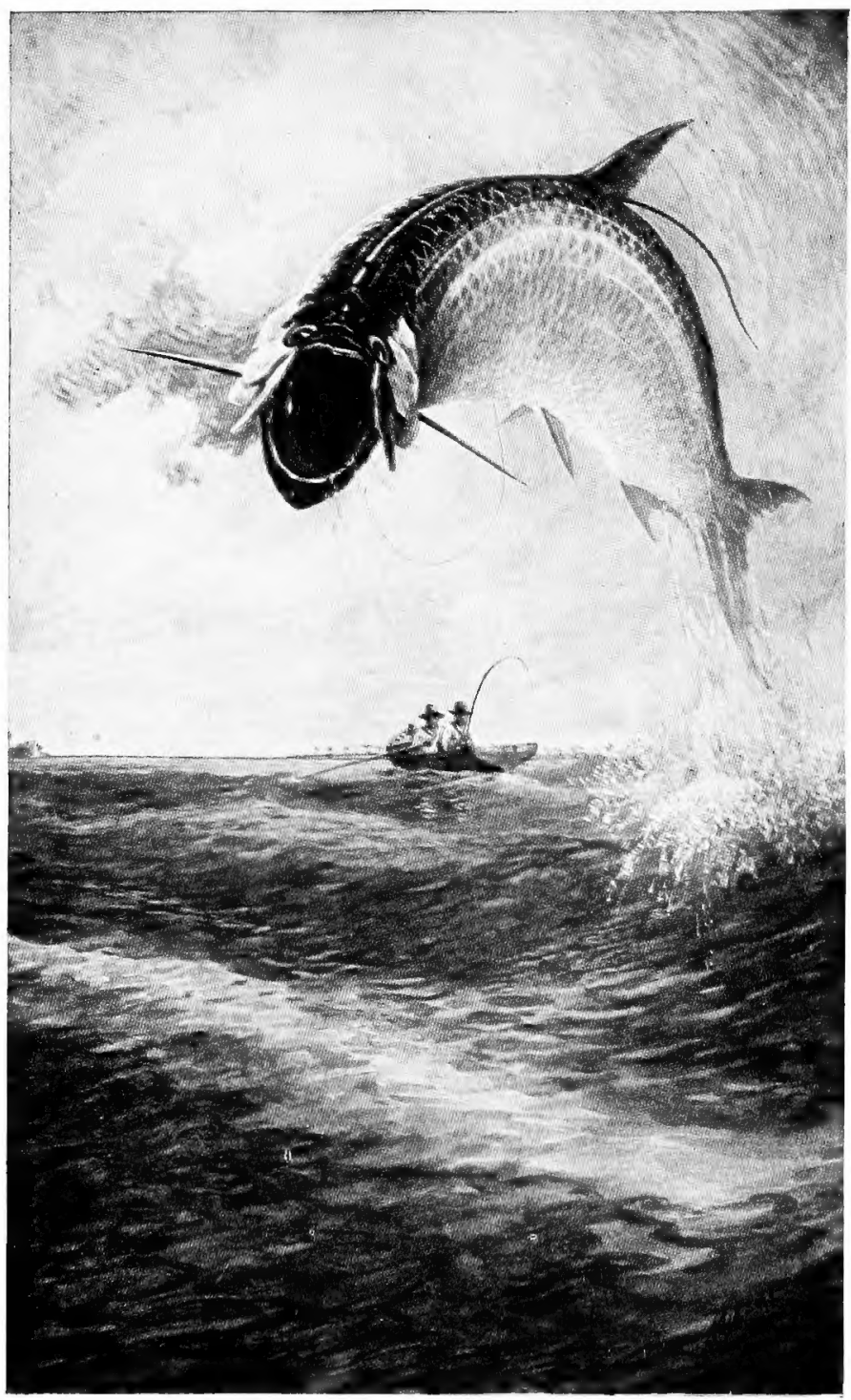






\title{
THE BIG GAME FISHES
}

\section{OF THE UNITED STATES}

BY

\author{
CHARLES FREDERICK HOLDER \\ AUTHOR OF "LIFE OF CHARLES DARWIN," "ALONG THE FLORIDA \\ REEF," "THE ADVENTURES OF TORQUA," "THE TREASURE \\ DIVERS," "LIFE OF LOUIS AGASSIz," ETC.
}

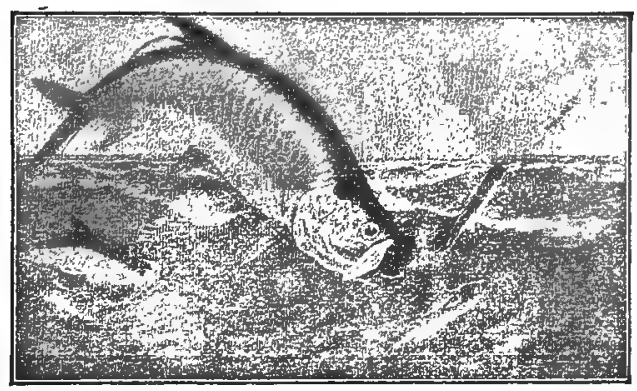

Nerom 1 and

THE MACMILLAN COMPANY

LONDON: MACMILLAN \& CO., LTD. 1903

All rights reserved 


\section{6}

COPYRIGHT, IgO3,

EY THE MACMILLAN COMPANY.

Set up and electrotyped January, Igo3.

Norbood 抻ress

J. 8. Cuphing \& Co. - Berwick \& Smith

Norwood Mass. U.S.A. 


\section{PREFACE}

Angling for the great oceanic game fishes, so far as it relates to the tarpon, tuna, black seabass, and others, is a modern pastime. The time was when the definition of game fish included the reservation that it must be edible, like the salmon or trout; but with the coming of the tarpon or the silver king, and the leaping tuna, preconceived notions were revolutionized. What tiger and lion hunting is to the sportsman, the taking of these ocean giants is to the sea-angler, who often takes his life in his hands, as with all the chances on the side of the fish he plays the great game in the open sea from one to fourteen hours. It is wild and strenuous sport, essentially manly, and nowhere is the true sportsmanlike spirit better exemplified than among its votaries who follow the largest fishes with tackle so light that the layman will often doubt the evidence of his eyes. In all the famous localities where gentlemen fish and sea-angling holds, the highest standard of sport prevails. In California alone there 
are over forty state associations devoted to the protection of fish and game, with a membership of over forty-two hundred. Besides these there are a number of clubs like the Tarpon Club of Aransas Pass, Texas, the Tuna Club of Santa Catalina, the Striped Bass Club of San Francisco, and others, which have so shaped public opinion that unsportsmanlike methods are rapidly becoming things of the past.

Every sea-angler has his peculiar methods, his rods, knots, lines, and hooks, and I may be pardoned for giving my own experiences among the great game fishes referred to in this volume, all of which I have taken many times in years spent, winter and summer, on the Florida Reef, among the Californian islands, and along the seaboard of nearly every state where fishes can be caught. These personal experiences are supplemented by the prevailing methods of the various localities so far as known.

While the volume is addressed to anglers from the sportsman's standpoint, data has been added relating to the structure, habits, measurements, geographical distribution, nomenclature, economic value of the fishes, and such other matter as would interest the sportsman-naturalist. The 
question of tackle and methods is of paramount importance to anglers, and as my own interest has been along the line of experiments with the lightest tackle, lines, and rods for the largest fishes, in the interests of fair play for the splendid game, I have included the reference to this feature in each chapter where the description of the capture of each fish and its peculiarities occurs.

The fishes represent an important and interesting branch of the animal kingdom. They are divided into about two hundred families and twelve thousand species, America alone claiming thirtythree hundred, which have been made the subject of untiring investigation, especially during recent years, by many distinguished specialists, among whom in this country have been Louis Agassiz, Charles L. McKay, Spencer F. Baird, James Carson Brevoort, William O. Ayres, David H. Storer, David Starr Jordan, Theodore Gill, George Brown Goode, Tarleton H. Bean, Samuel Garman, Barton W. Evermann, and many more whose works are found in the United States Government Reports and those of the various institutions of science in this and other countries. Among these may be mentioned the works of Louis and Alex- 
ander Agassiz; " The Fishes," by Garman, in the Memoirs of the Museum of Comparative Zoölogy at Harvard College, vol. xxiv, a most valuable and sumptuous series; "The Fishes of North and Middle America," exhaustive and valuable volumes issued by the Smithsonian, representing a part of the life work of David Starr Jordan and Barton W. Evermann; "Oceanic Ichthyology," a monument - if any was needed - to the splendid abilities of the late Dr. G. Brown Goode and his colleague, Tarleton H. Bean; Jordan and Gilbert's "Synopsis of the Fishes of North America"; "The Aquatic Resources and Fisheries of Porto Rico," by Barton W. Evermann; "The Fisheries and Fishing Industries of the United States," by Dr. G. Brown Goode, and many more; and to them, sportsmen and anglers - always naturalists in the broadest sense, lovers of nature - owe a lasting debt of gratitude for making available technical information regarding the game in which they are particularly interested. Then comes the literature of the gentle art of angling and the angler, the lover of fishes, dating from the time of Athenæus, Oppian, Alian, Rondeletius, Dubravius, Pliny, Plutarch, Aldrovandus, the immortal Du Bartas, and many others, the memoirs 
of the men who have founded a philosophy of their own, and lived by it, under the sign of the fish. It is impossible even to mention all the worthies who have aided in making life happier, brighter, longer for themselves, and shorter for the fishes. There is Walton of blessed memory, with his discourse on fish and fishing; Richard Franck; John Dennys and his "Secrets of Angling," г6г 3; "Salmonia," by Sir John Davy; "Chalk Stream Studies," by Charles Kingsley; Penn's "Miseries of Fishing"; Robert Boyle's "Angling"; and a hundred more, down through the names of Andrew Lang, R. D. Blackmore, Thaddeus Norris, Frank Forrester, Robert B. Roosevelt, Dr. Yale, William C. Prime, Henry P. Wells, William Black, Henry Van Dyke, Dr. Henshall, Dr. Kenworthy, Fred Mather, and many more. The literature of the subject is endless. Dr. Goode, in the prologue to his "Game Fishes," says: "My own library of works on fish and fishing is far from complete, yet it includes over two thousand volumes and pamphlets, and my Bibliography of American Ichthyology, which I hope to publish within the next two years, comprises nearly ten thousand titles of books and papers. A large number of these 
works relate to the scientific investigations of experts and specialists, but it is not too much to say that an equal number are devoted to the art of angling and the capture of fishes." I am indebted to the United States Fish Commission for the outline drawings of fishes in this volume, which have been taken from the originals in the late Dr. G. Brown Goode's Government Report, entitled "The Fisheries and Fishing Industries of the United States."

C. F. H.

Pasadena, California,

January I, 1903 . 


\section{CONTENTS}

CHAPTER

PAGE

I. The Structure of Game Fishes . . . I

II. The White Sea-bass . . . . . . . 14

III. The Gray Snapper . . • . . 33

IV. The Leaping Tuna . . . . . . . 5 I

V. The Barracuda of Florida . • • . 88

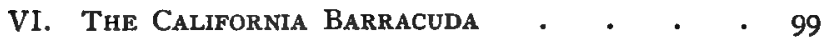

VII. The Black Sea-bass • • • • • . 105

VIII. THE HogFish . . . . . . . . 118

IX. The YellowtaIl • • • • • • • I33

X. The Bluefish . . . . . . . . 152

XI. THE JACK . . . . . . . . 163

XII. The California Sheepshead . . . . 175

XIII. The Channel-bass - . - • • . I87

XIV. The Albacore - • • . • . . 200

XV. The Groupers . . . . . . . 2 II

XVI. ThE TARPON • . . . . . . . 223

XVII. The Blackfish . • • • • • 274

XVIII. The KINGFish • . • • • • $28 \mathrm{r}$

XIX. The Florida Jewfish . . • . . . 298

XX. The Drum • • • • • • • • • 309

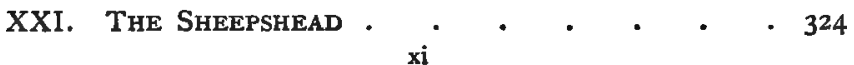


xii

CHAPTER

XXII. The Parrot-fishes . . • • • 333

XXIII. The Dolphin . . . . . . . 342

XXIV. The Mariposas . . . . . . 350

XXV. The Halibut • • • • • • • 359

XXVI. The Leaping Sharks . . • . $37 \mathrm{I}$

XXVII. The Chinook of Monterey . . • $\quad 3^{83}$

XXVIII. Game Fishes of the Colonies • • 397

XXIX. BAIT AND GRounds . . . . . . 408

INDEX $~ \cdot \quad \cdot \quad \cdot \quad \cdot \quad \cdot \quad \cdot \quad \cdot \quad \cdot \quad 425$ 


\section{LIST OF ILLUSTRATIONS}

The Battle Royal (In color) . . . . Frontispiece FACING PAGE

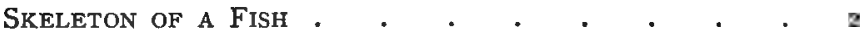

Diagram of External Structural Features . . 3

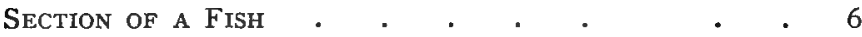

Catch of White Sea-bass . . . . . 24

The Gray Snapper and its Friends . . • . 37

The Leaping Tuna (Iri color) • • • • • • . 54

The leaping Tuna, Santa Catalina . . . . 58

Figures showing Tuna and Tarpon Reels . • • 59

A Rod - Exact Size of Standard Irish Linen Lines

FOR ANGLING . . . . . . . . . 6I

ANGLER'S KNOTS . . . . . . . . . . . 62

Hooks, For Yellowtail, Tuna, or Black SEA-Bass

FISHING • . . . . . . . . , 63

Methods of baiting Tuna Hooks . . . . . 64

Figure showing the Size of ReEL - Figure showing

POSITION OF HANDS . . . . . . . . . 74

Playing the Leaping Tuna . . . . . . $\quad 76$

C. F. Holder and his Record Tuna . . • . 78

The World's Record Tuna . . . . . . 80

The Barracuda (In color) . • . . . . . . 94

LARgEST Fish EVER TAKEN With A ROD By A WOMAN • 106

RECORD Black SEA-bass . . . . . . . I16

SNook; Sergeant-Fish - Yellowtall or White Sea-

BASS AND Bluefish HoOKS . . . . . . 132 
Sea-Lions in Water Where is the Best Yellowtail

Fishing in California . . . . . . . 138

YellowtaIL OR AMBER-FISH - HoOK WITH Wire to CLOSE

THE Mouth OF Fish BAIT - SARdine OR HERring

BAIT FOR YellowtaIL . • . . . . . I40

Hard-tall, "RunNer" - Crevallé, "Cavally," "JaCk"

- Bluefish • • • . . . . . . . I54

SURF-CASTING FOR BLUEFISH (In color) . • • . 157

RED DRum, "ReD-Fish," "ChanNel-bass" - Rig FOR

Grouper, Red SNAPPER, etc. . • . . $\quad$ 188

The Channel-bass (In color) . . . . . . . 190

The LaRgest Tarpon EVER CaUght WITH RoD aND ReEL 224

TARPON FEeding ( $I n$ color) ) . . . . . . . 226

Red Grouper - The little Joker . • . . . 228

Tarpon; Tarpum - Common Mullet; Striped Mullet 232

EDWIN VOM HofE'S TARPon, Which Was THE WORLD'S

RECORD FOR A TIME . . . . . . . 234

ThE Florida JeWFish (In color) . . . . . 302

Spanish Mackerel-Drum; Gray Drum . . . 3I4

SHEEPSHEAD - TRIPLE-TAIL Flasher . . . . . 332

Halibut - Chinook, King or Quinnat Salmon - . 360

The KingFish (In color) . . . . . . . $\quad 386$

California Herring - Surf Smelt . • . . . 412

BaIted Hooks . . . . . . . . . 416

California Smelt-Bull's Eye or Chub Mackerel - 420

CASting From the BeACh FOR Bonito . . . . 422 


\section{THE BIG GAME FISHES OF THE UNITED STATES}




$$
\text { - }
$$




\section{BIG GAME FISHES}

\section{CHAPTER I}

THE STRUCTURE OF GAME FISHES

A Fish may be termed a cold-blooded, gillbreathing, backboned animal, adapted to life in the water, through which it moves by the aid of fins, which correspond to the limbs of other animals. The true fishes are represented by the types treated in this volume, and a glance at the skeleton, divested of skin and flesh, affords the angler an idea of its structure, and the relation of its parts one to another. The skeleton of a typical bony fish like the perch appears to have two backbones, but the central one (68) is the vertebra, made up of sometimes two hundred sections. Each vertebra is hollow on the ends, the space so formed being filled with a glutinous substance, the edges of the bones being connected by ligaments, which allow more or less lateral motion - a vast amount in the eel, very little in 
the tuna. The long bones (12) attached to the backbone are the ribs which form the frame of the abdominal section, while projecting upward from the vertebræ are bones $(c)$ which may be termed braces to the upper and fleshy portion of the fish. The pseudo-backbone above $(74,75)$ is the framework of the top or dorsal fin, certain spinous bones (74) extending downward, embedded or anchored in the flesh forming the base of the dorsal spines (75), which extend upward clear of the body and there connected by a web or membrane, or not, as the case may be, become the dorsal fins (75). Sometimes there is but one, as in the tarpon; again two, as in the perch. The head is a complicated organ made up of many bones; the jaws armed with teeth. The lower jaw has a wide range of movement, and if a fish is hooked here, the mouth is pulled open and the contest is not so interminable' as when it is hooked in the upper jaw, when it can close its mouth upon the hook. In tuna fishing this often makes a vast difference in time; hence some facile anglers claim that the fish should be hooked with a lateral motion instead of an upper; in other words, the lower jaw should be hooked, if possible, when the game is large. 


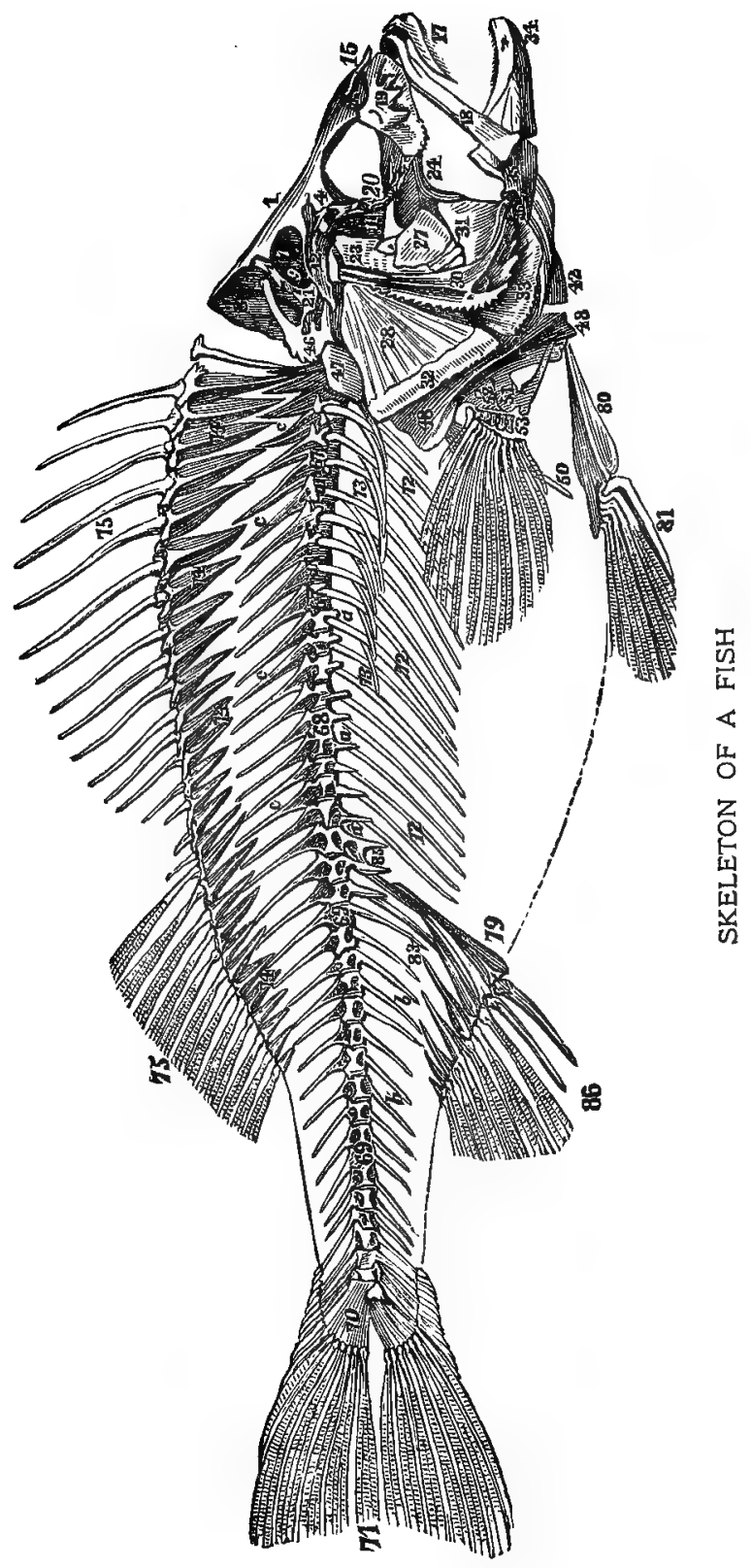




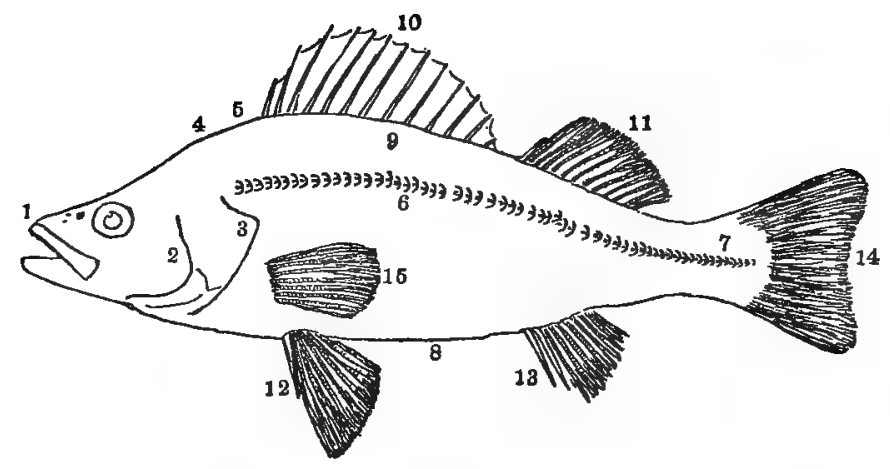

DIAGRAM OF EXTERNAL STRUCTURAL FEATURES

1. Snout

1-4. Profile

2. Cheek-bone (preopercle)

3. Gill-cover (opercle)

4. Nape

5. Shoulder

5-6-7. Lateral line

7. Base of caudal fin
8. Ventral line

9. Dorsal line

10. First dorsal fin

11. Second dorsal fin

12. Ventral fin

13. Anal fin

14. Caudal fin

15. Pectoral fin 
The large bone (28) is the cover, or door, to the gill chamber, which opens and closes convulsively when a fish is landed. The fish smells but does not breathe by its nostrils, the nasal aperture being shown at (I 5).

In the skeleton the arrangement and use of the limbs, or fins, is readily seen. The top or dorsal fins (75) are balancers, upper centre-boards, capable in some fishes of a decided screwlike movement, enabling them to move. It also is an expressive organ, erect when the fish is excited, low or folded at other times, and incapable of movement in certain forms. In the tuna it fits into a scabbard, or notch. The tail, caudal fin ( $7 \mathrm{I}$ ), is the most useful locomotive organ, controlled by powerful muscles and lashed about by the entire sweep of the body; it is readily seen that by it the salmon makes its tremendous leaps and the tuna literally whirls itself into the air, nearly all fishes using it as a screw. The peculiar motions are readily observed in a soft-tailed fish, like the perch, in confinement.

Directly below the second dorsal fin, near the tail, is the anal fin (86) and its bones, held in place by spines (79), which are placed firmly in the muscular tissue. It is these interspinous and 
rib-bones which make fishes so "bony," as in some species, like the shad, they are very long and slender, giving the impression that this popular fish must be very uncomfortable. This anal fin is not a locomotive organ, being merely a balancer to aid in preserving the equilibrium of the fish, a sort of centre-board and a rest when the fish is reclining on the bottom. The limbs which correspond to the locomotive organs of other animals are the pectoral (50) and ventral (8I) fins. The former are the most important next to the tail as locomotive organs. Fishes, as the California sheepshead, the parrot-fishes, tautog, and others, rely upon them to a decided extent, the flapping or waving motion being readily observed; but when rapid and sudden motion is desired, the tail is brought into play, finding its most remarkable development, at least in my estimation, in the California flying-fish, where it twists violently about, hurling the fish into the air with such force that, supported by the broad pectorals and ventrals, the fish becomes an animate aëroplane and soars over the sea, never flying, for over an eighth of a mile. The pectoral fins (50) are modified into forearms, paddles; and many of the corresponding bones among higher 
animals are seen, as a pectoral arch, scapula, clavicle, ulna, and radius. These fins are found in the greatest variety from the long, slender, sabrelike fin of the albacore, to the enormous webbed, winglike organ of the flying-fishes, resembling a true fore limb in the peculiar fish, the periophthalmus, which uses its pectoral fins as feet to hop along the muddy shores out of water, in search of food. Below the pectorals we find the ventral fins (8I), rays, attached to the pelvic bone (80), representing the hind legs of higher animals, though all the bones of the limbs are not present. These fins are of little if any use as swimming organs, but the fish rests upon them when on the bottom, and they are balancers, aiding, as do the others, in preserving the perfect equilibrium of the body while the fish poises. The angler who makes a diversified catch, as is often the case in Florida, will be highly edified by a comparison of these fins in the different fishes, suggestive of their habits and game qualities.

We have taken a superficial glance at the framework of the game fish. It is a marvellous machine, built, framed, fitted, joined, provided with paddles and screws to give it speed, endurance, resisting power; in a word, perfectly adapted 
by nature to its environment. Now to look at its internal economy, not thoroughly, as textbooks are at hand, but merely to afford the angler between strikes a general idea of how his game eats, breathes, and makes so determined and gallant a fight. A section of the fish is shown in Fig. 2. Lifting the gill-covers $(b r)$ near where the fish should be gaffed, we see the gills, blood-red membraneous leaflets supported by cartilaginous arches, separated by slits. These are situated in branchial chambers or breathing rooms on each side of the head, and are the lungs or breathing organs of the fishes, though in some forms the airbladder assumes this function when the fish leaves the water. The fish obtains its oxygen at second hand, using minute particles of air which are held in the water. Storms and winds raise a sea which forces air-bubbles down below the surface, aërating the water in sufficient quantities to support life. To demonstrate this it is but necessary to place a fish in an aquarium and allow the water to run in from below; the fish in a short time languishes and rises to the surface and dies. Introduce the water from above, imitating the action of a wave so that it falls upon the surface with force, carrying down air, which is seen permeating 


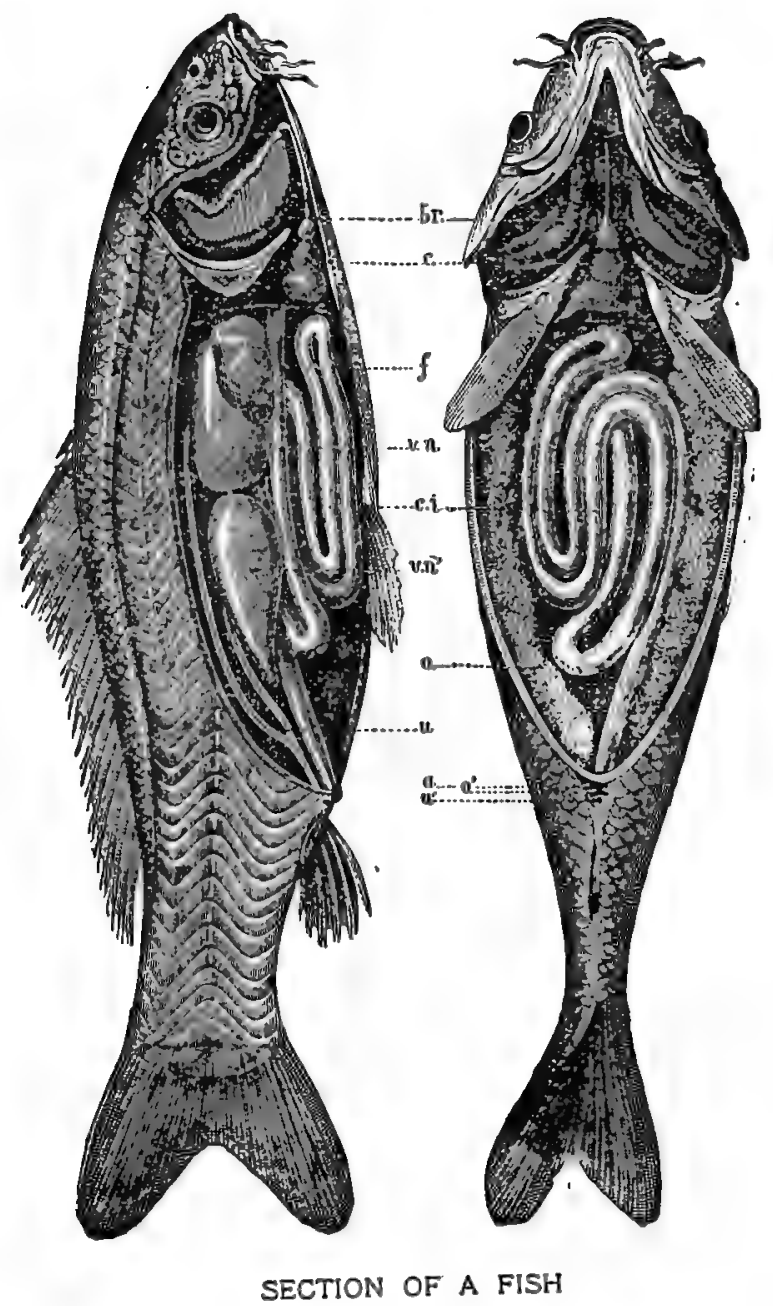



the water in a cloud of minute bubbles, and the fish is immediately at ease. The deep-sea forms obtain the limited oxygen which they need from slow-moving currents which sweep along the bottom of the ocean at the greatest depths, passing from the surface to the abysmal regions laden with oxygen. The gills are permeated with blood-vessels, which give them their rich color, and their office is to take oxygen from the water, the operation being as follows. Watching a fish in confinement, a continued movement of the mouth and gills is observed, an endless opening and shutting; indeed, the fish's mouth is never closed. It is taking in water which passes over the gills, bathing them in an endless stream. As it passes, the gills take up the oxygen contained in the fluid; this is absorbed by the blood, which is being pumped by the heart to the gills for this purpose, as blood in man is pumped to the lungs to receive the oxygen taken in at the nostrils. The water so used is thrown out at the gill openings by the depression of the operculum, or door, or cover of the gill chamber. The passage of blood through man is rapid, and he is warm-blooded; in fishes it moves very slowly, and the temperature of the blood is lower than that of the surrounding 
medium; hence the fishes are said to be coldblooded. But in the tuna, bonito, and others the movements are so energetic that the temperature is higher than that of the water. When a fish is taken out of the water; it gasps and opens its gills, and doubtless is killed in part by too much oxygen, the reverse of the drowning process.

The digestive organs of fishes are simple. The prey is not chewed, the teeth being intended to hold the victim, which is swallowed entire at one or two gulps, though the tuna often crushes its prey. Food is quickly digested, and the capacity of some fishes, as the tuna, bluefish, and others, is remarkable. The mouth and teeth are modified or adapted to the requirements of the fishes. Those which live on oysters, as the sheepshead, have crushing organs. The shark, not a true fish, cuts its food or tears it. The fish is enabled to hold its position at various levels without effort by the aid of its air or swimming bladder (vn), possessed by most individuals. This is a silvery air sac or balloon lying directly beneath the vertebra, longer or shorter according to species, absent in some. It contains gas, principally nitrogen, and by it the fish is enabled to retain a certain specific gravity. 
The brain of the fish is very small, and the latter has limited intelligence. Its powers of smell are fairly well developed, and the hearing is more or less acute; the organs of hearing being small cavities on each side of the head, containing a liquid in which float two ear-stones or otoliths. In some fishes, as the California "groupers," the stones are an inch in length, pearl tinted and flinty, - attractive objects in demand as "headstones" and "good luck stones."

The fish is enveloped in scales, which in the game fishes described overlap each other like shingles. They grow out of the little pockets in the-skin and are moistened or lubricated by a secretion or slime, always noticed in a fish, which exudes beneath them, and particularly along the median line, an undulating line extending from the head to the base of the tail. The game fishes mentioned in this volume all increase by depositing eggs or spawn, the eggs - minute spherical objects - often forming enormous masses. The caviare of commerce is the roe of the sturgeon. The number of eggs is inconceivable. In the cod it is estimated at five millions. This is a wise provision of nature, as fishes feed upon their own kind. Sardines, herrings, and many birds devour 
spawn, and out of every million eggs deposited, a very small percentage, certainly not ten, attain the adult stage. There are great concerted movements at the spawning period. Some fishes pair. The female, as a rule, pays no attention to the eggs or young, and in nearly all instances where nests are constructed, as in the case of the stickleback, the sunfish, Semotilus, lamprey, and many more, it is the male which builds the nest. The Acará carries the eggs and later the young in its mouth.

The spawn is deposited in the open sea, in the case of the tuna, albacore, bonito, and other pelagic fishes; at the surface in bays, as in the case of the flying-fish. Some fishes, as certain California sculpins, attach eggs in great clusters to rocks; others again, as the rock-bass, form a simple nest, while others, as the salmon, deposit the eggs on sandy or gravelly bottom; some, as the blackfish, among weeds or grass. Over the eggs the male distributes the milt which impregnates them, and in a greater or less time the young appear, immediately becoming the prey to a thousand enemies. Some fishes possess the schooling instinct, as the herring, sardine, California barracuda, mullet, and others; the ma- 


\section{The Structure of Game Fisbes}

jority separate. Many young of pelagic fishes attach themselves to large jellyfishes; others to the physalia, and some adults enter the intestinal tube of holothurians.

There are two other methods of reproduction among fishes and the fishlike animals. In some, as the surf-fishes and certain sharks, the young are born alive. The young of twenty or thirty or more surf-fishes school and swim together. Other fishes are ovoviviparous, the eggs being retained in the body until the young are hatched.

In the vast concourse of fishes of the world every possible habit is seen. Originally all were doubtless salt-water forms, but they have entered rivers and streams, and in time have become adapted to their environment. Some fishes, like the salmon, enter fresh water to spawn. Others, like the eel, seem to reverse this. Certain fishes hibernate when water disappears. Others cross overland to reach water, while the strange periophthalmus and another genus leave the water and wander along the shore in search of food.

The fishes are found at various depths of the ocean, some at a depth of several miles being blind. Those living in these abysmal 
regions are adapted by nature to the peculiar conditions. The pressure where they live is sufficient to powder glass; at the surface it is fifteen pounds per square inch, but increases rapidly, so that at a mile below the surface it is almost beyond comprehension.

To overcome this the skeleton of deep-sea forms is cavernous, porous, and the water appears to circulate through them as through a sponge, and although fierce and carnivorous creatures, they are so fragile out of water that when taken from the nets they almost drop in pieces. The most remarkable feature of these fishes and many surface forms is their phosphorescence, many having illuminating organs - torches - of one or more colors, which constitute a part of the illumination of the deep sea, and serve possibly as a signal language by which the sexes are attracted, or predaceous forms lure their prey. I have seen a tuna come up at night, having a train of light several feet in length, but this was due to the luminous animals in the water - the peridinium, salpa, and others.

The game fishes available to the rod fisherman constitute a small proportion of the fishes, 
due to the fact that many are deep-water forms, or so essentially pelagic, like the dolphin - a splendid game fish - that it is beyond the reach of the angler who cannot spend his time in the forechains of some ship. This is exemplified by the statement that nearly all the available large oceanic game fishes of America, except the striped bass, are included in this volume; but as each is a game fish of several sizes, in the course of its career the angler finds endless variety. He can begin with a fly-rod on a two-pound bluefish, and will need his stiff rod on the adult. There are in California and Florida an infinite variety of small fishes, usually neglected, which, if approached with a rod, afford profitable sport. 


\section{CHAPTER II}

THE WHITE SEA-BASS

"If I can but hold him." - IzAAK WALTON.

There is an element of chance in sea-angling found in no other sport. I remember that my old boatman on the St. Lawrence knew every rock and shoal in a thirty-mile row around Grenadier Island and would often indicate a strike in advance. So with trout-fishing, every frequenter of certain streams has the picture of favorite pools photographed on his memory. With the sea-angler the reverse holds. He "grasps the skirt of happy chance" and boldly sails out upon the unknown sea of Fortunatus without pointer or tip, with absolutely nothing except his inherent luck, upon which he stakes his all on this happy day.

The sea-angler is often superstitious. $\mathrm{He}$ has his whims and fancies. He assumes that a lost fish tells its companions; that it is worse than useless to fish on the ebb tide, and doubts 
not that certain people, usually poor gaffers, literally hoodoo the sport. Of all things, he is a believer in signs and omens and especially in luck. A strange fetich, this luck, which every angler woos with more or less success. "What luck?" shouts a friend from a passing boat; and if you have bagged your game, it is, "Joe, hold it up." And Joe holds forth a sixty-pounder, displaying every angle, that the iron may enter the heart of the rival boatman in the other craft, who has not gaffed even a gudgeon that day. But if there is no luck, no sixty-pounder, the angler merely pretends not to hear, and his boatman raises his hands aloft, opening and closing his fingers in a mystic signal which can be interpreted from six to ten or anywhere along the line. Not St. Peter, but Ananias, is his patron saint. What is luck? I have fished for hours by the side of a friend, where rod and bait seemed identical, and either he or I caught all the fish and had all the strikes. The luck was all on one side.

I have seen a lady, fishing with two anglers whose fame had reached halfway around the world, catch all the fish, five splendid white seabass, all over fifty pounds, despite the fact that 
she had never held a rod before. She used the same tackle, the same bait. Her ungallant companions changed the rod, insisted upon exchanging seats, but they failed to change her luck. From the time Deucalion

" Did first the art invent

Of angling, and his people taught the same,"

the uncertainty of fisherman's luck has been proverbial; but perhaps this ephemeral luck, so potent to make or unmake a fishing day, has more in it than appears on the surface. You as well as I have perhaps often noticed that the lucky fisherman is a person of method. If a fisherman becomes possessed with the idea that a two-dollar reel is as potent to take tarpon and tuna as one costing fifteen or twenty dollars, that man is more than likely to attain a reputation as having poor luck. The man who never changes the line from the lower to the upper guides, who uses a line one hundred times, who has a theory that the ebb tide and the afternoon are best for fishing, is more than likely to be unlucky. This old man of the sea, "hard luck," will surely fasten upon such an one. You perhaps have observed that the angler who soon becomes weary of the 
constant waiting that is sometimes the feature of the day's luck, and thrusts his rod beneath his knee to read or drop asleep, is always a victim to poor luck, as by some occult eighth or ninth sense the fish invariably selects this exact moment to strike the bait, and it is always the largest fish which have this artful discernment. This is so infallible a rule, so well known among seaanglers, that I have often changed my luck and forced a record fish to bite by merely dropping my rod into the oarlock, pretending to be engaged in some minor distraction. The moment I was thoroughly involved, my face deep in the folds of a coat, hoping to form a conjunction between cigar and match, the fish would strike; but it was a subterfuge, and before the fish had taken ten feet of line, I was ready for the play. I deduce from this that good luck means good and careful equipment, a good gaffer and boatman, good reels, lines, hooks, and the right kind of bait all the time; in a word, the application to fishing of the same rules which make one famous or successful in any phase of life.

It is worth crossing the continent in June from New York to Avalon to sit on the veranda of the hotels and listen to the tuna anglers, at the 
end of an exciting day, explain why and how the fish got away. It is always ascribed to bad luck. One man played his fish three hours, when his heart gave out on account of a recent attack of grippe. The handle of a cheap reel came off. Ananias, the veteran gaffer, who perchance had never gaffed before, forgot to change the worn line. Another angler caught his line about a button at the end of four hours; and so on. Anglers "smiling at grief," yet heaping agony upon the back of patient luck which brings them all their joys.

I esteem myself a lucky fisherman because of one catch, a white sea-bass which I took one rosy morning at Santa Catalina with very light tackle and in very good company. It came about, as such things do, unexpectedly. We were lying on the sands of a little cove under the shadow of a ridge of Mount Black Jack; the launch was anchored near shore, the boat hauled up on the beach. The little bay was, that rare thing at this island, shallow, the bottom sinking gradually away five, ten, fifteen feet, until sixty or seventy feet from the shore it dropped into the channel. The water was as clear as crystal, the surface as smooth as a disk of steel. Not a breath came 
from the high rocky ridge, and all nature seemed asleep. As my eyes rested on the picture, an ideal place to play a fish, the unexpected happened. Two, three, four, five fins came into view from behind a rocky point just as I had been figuring them, as though some one had given the cue and the finny actors had stepped out from the wings on to the scene, a tragedy in one act. They moved along with great deliberation, the big dorsals waving gently and the tips of the caudal far astern, so that it was an easy matter to construct the entire hidden fish. It was a school of white sea-bass, apparently none of which was under fifty pounds. On they came, not twenty feet from the beach, and, as I rose, their bulky forms were sharply outlined against the dark olive-hued bottom.

My rod and line, baited with flying-fish, was lying in the small boat - note this premonition of coming fisherman's luck. It took but a moment to grasp it, and so deft and agile was the boatman that my bait, as he pulled offshore, crossed the school, dazzling the very eyes of the dignified strollers along this fishes' rialto. One at least resented the intrusion. There was a swirl of waters, a boiling seething as the school 
awoke to the fact that one had fisherman's luck; then followed a brief pause; to swallow a flying-fish one foot in length, is not accomplished at once; and I could see the monster poising, swallowing with convulsive gulp; then feeling the wire leader, it shot ahead, and for an instant I gave the butt to one of the finest white seabass that ever swam, which when hooked, unreeled the line to a new music of the reel. There was no stopping this splendid rush, and with thumb trembling on the pad, the tip bending to the danger point, the boatman backing with one oar, pulling with all his power on the other, to whirl the boat around, my companion breathing advice and caution in low tones, the reel swearing, praying, protesting, ah! it was an exciting moment, one of those critical points in the life of an angler that comes but once and is gone. "If I can but hold him!" Walton whispered on a similar occasion. If! what a world of chance and possibility is tied up in that small word! If the line had only been newer; if the leader had not been rusty; if that knot had been cut out, or if you only had taken a gaffer who did not lose his head, - each and any of these "ifs" might have reversed this day of happy memory. 
But I was in luck, and this catch has lived with me ever since. Possibly the bass has grown a little every year, gained a pound or so in the telling, but it would have done the same had it lived, and far be it from me to deprive so noble and generous a creature of any prerogative; living or dead, it shall grow, at least so long as my gaffer lives.

We have left the fish rushing madly. I had caught many bass, but never in shoal water. They are taken almost invariably in the deep blue water along the rocks, and will often, like a salmon, or almost any fish, plunge down and sulk; but this fellow could not sulk, hence was away, and when I checked it, it dashed around, circling the boat so rapidly in a series of rushes that only by heroic measures was it saved. Twice or more the dash was so impetuous that the rod was quickly passed under the oars of the boatman to save it, he sending the flat-bottom boat around on a pivot in a desperate attempt to keep me facing the fish. Fifteen or more minutes slipped away, the bass making inshore rushes to secure line, with which to reach the deep channel. But the boatman hugged the shore, and by sheer luck I kept the plunger in 
shallow water, where we could feast our eyes on its every move. Its bearing off was splendid, and so powerful was the fish that only the oarsman kept it from going out to sea with skiff and men. Slowly it came in, now stopping, beating the water; now dashing off with all the line gained by strenuous endeavor, shaking its bulky head and every second testing line, rod, and angler. There was no Timoleon in that dancing, whirling craft, to boast of his luck and see it take wings, but three men in good luck, who finally saw the great fish come slowly to the gaff. It circled the boat to the last, and was gaffed, bearing off heavily, bending the slender rod into a bow as it passed the gaffer, still vigorous and full of fight, beating the water with its big tail, hurling the foam over us, literally tossing defiance in our faces as I unreeled the line to permit the gaffer to slide it in, blazing in all the colors of its kind, as he held it up a moment that we might look upon its splendid proportions.

The actual weight of this fish was fifty-two pounds several hours after the capture, and the time occupied in its undoing was nearly half an hour. The bass as it lay on the canvas fish-bag was a picture for an artist; nearly four feet long, 
of a grayish golden color above, merging into silver upon the belly. About the head, the scales were iridescent, flashing all the hues of a peacock, blue and green, a dazzling creature when seen just from the water. The fish was well proportioned, long, fairly slender, a noble fish, and well named Cynoscion nobilis (Ayres), the weakfish of California.

This bass represents a genus well known in American waters, about twenty species having been described. It ranges the coast of California even to Canada, and is most common from south of Magdalena Bay to Santa Barbara; but it is very uncertain in its movements, and equally so in biting. The season may, theoretically, be said to be from May I to July, or even August, but some seasons the fish is very rare and will not bite; again it comes in numbers and affords sport long to be remembered.

On the first of May, I899, with a fellow-angler ten of these fishes, all over fifty pounds in weight, were taken between nine and twelve o'clock, not one hundred feet from the beach in Avalon Bay. A large school entered the bay and remained ten days, affording excellent sport. In our boat, my companion and I each hooked a large fish at the 
same moment. One rushed ahead, the other darted astern, and we were at once involved in a most spirited tug of war, which resulted in the loss of one fish. At one time twenty or thirty small boats were fishing, and sometimes half of these would have bass hooked at the same time; the scene as the big fish towed the boats about, the cries and shouts as lines were parted or rods succumbed, being a most animated one. I recall one rush of a bass hooked by a lady, which towed the boat almost entirely across the bay before the fish could be checked, the game later tipping the scale at eighty pounds.

The large bass I took in the little shallow bay was caught with much lighter tackle than generally used, the line being a number fifteen cuttyhunk, which I commend, as the fish, with proper care, can be caught with even a smaller line, if in moderately shallow water. The only drawback to very light lines is the fact that the sulk: ing fish must be lifted at times, when a little carelessness will break the line. Better lose all than to slay so gamy a creature with a hand-line or anything larger than a twenty-one-thread line. In the matter of rods, a seven- or eight-foot rod weighing from fifteen to eighteen ounces, of split 


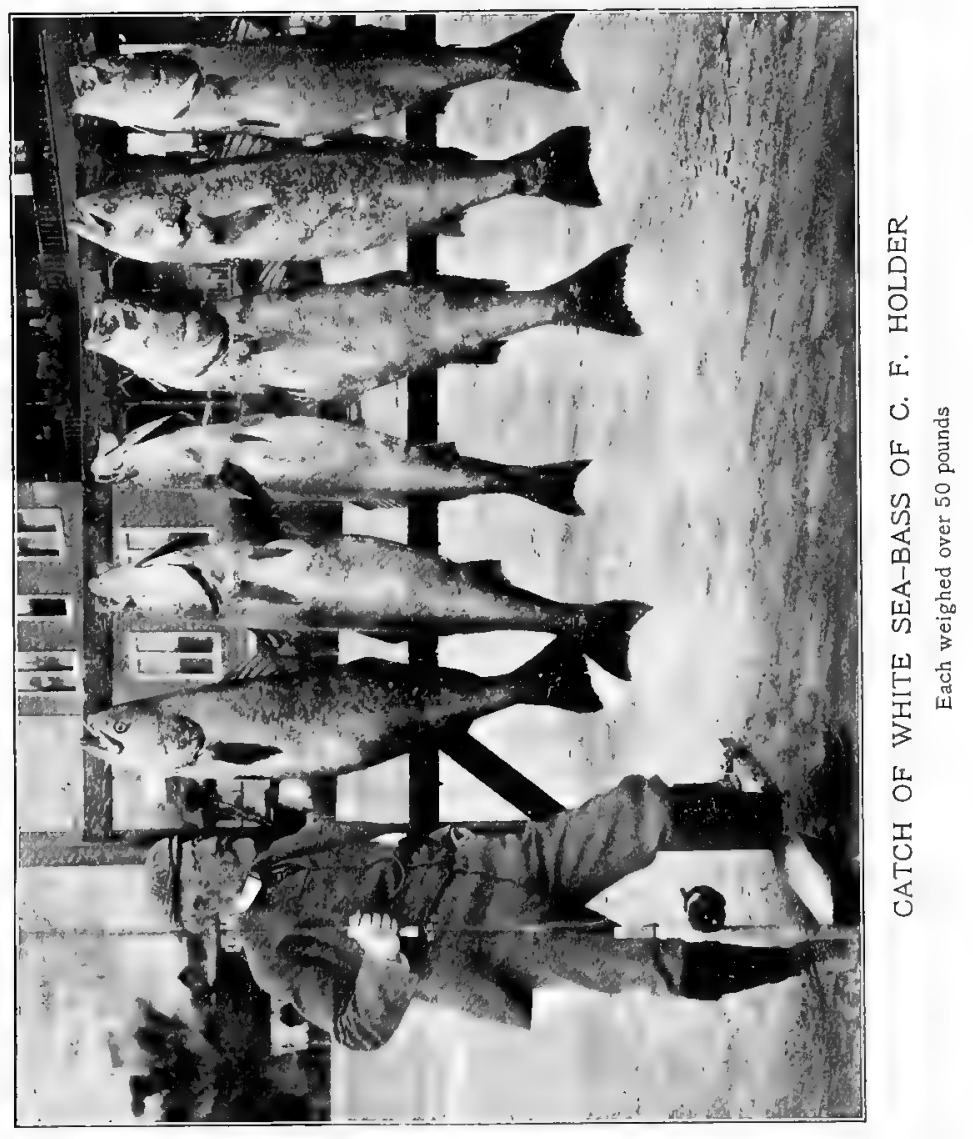




\section{.}




\section{The White Sea-bass}

bamboo, greenheart, or any good wood, is employed. I have used light rods for these fishes, which compare with the striped bass of the East; in fact, the white sea-bass takes the place of the latter as a sport in Southern California, but I have fished with a much lighter rod for my fiftypounders than is used for a striped-bass of this weight at Cuttyhunk and elsewhere. As a matter of fair play, the rod should be seven or eight feet long; and if the water was always shallow, longer ones could be used. At the islands where these fishes most do congregate, the water is often extremely deep and blue a stone's toss from the beach, and a sulking fish two or three hundred feet down must often be considered after a rush; hence the rod must be sufficiently stiff to enable the angler to bring it to the surface. The majority of the catches are made in the bays, in fairly shallow water, and as the well-equipped angler will have several rods he can adapt himself to circumstances. The line should be a number fifteen, or smaller, despite the size of the fish, if the latter is to have the advantage, which of course is essential; and the hook, a 9/o Limerick, or an O'Shaughnessy, or any good hook of this size, with a piano-wire leader a foot in 
length; gut or salmon leader is soon worn off by the fine teeth of this noble Cynoscion. The bait, if a smelt, six inches in length, is impaled through the mouth, the point thrust into the belly of the fish, and the mouth of the latter bound or closed and fastened to the shank of the hook by a silver wire, which should be attached to every hook; it prevents the bait from whirling and the line from untwisting. The leader should bear at least two swivels. Spoons, and all kinds of artificial baits, are useless, at least in my long and continued experience, the fancy of the great bass - and the term bass is a localism - being for very large baits, as the flying-fish or smelt, a prodigious lure for even so large a fish.

In searching for this game the boatman rows along the rocky shores of the islands in perfectly smooth water, not sixty feet from the high massive cliffs which merge into mountains. Often the strike comes within a few feet of the rocks; yet the water may be two hundred feet in depth, so precipitous are the shores, blue water being found at the very portals. Again little bays are entered, the mouths of deep cañons which wind upward, the great bass being fond of such places; and in 
the larger bays, as the Isthmus, the angler can sometimes go ashore and cast from the beach, and land these splendid fishes under ideal conditions.

The method of fishing en règle is to troll slowly, with sardine, smelt, or flying-fish bait, just outside the kelp. The fish comes in small schools, almost always swims on the surface, and can be recognized at once by its dorsal fins above water. It frequents little bays or indentures in the kelp, and I have taken it by lying off and casting forty or fifty feet. Even the tremendous bait, a whole flying-fish, dropped into a school, does not alarm them, as this is the habit of the flying-fishes, to drop with a crash. The solidity of these fishes, the difficulty to move them, can be illustrated by an incident. A boatman took my rod while I was fishing for larger game and cast it into a school, where it was immediately seized by a large bass. The man struck so heavily that the rod broke off just above the butt, the fish not being moved by the shock. Of course the break was entirely unnecessary, but it illustrates the point. I have been most successful in taking this bass by following large schools of sardines upon which they prey. The bass chase them in, tak- 
ing their position beneath them, a huge fish being occasionally seen by the angler down through a funnel of sardines as the line sinks. In May or the latter part of April one or two large schools of sardines enter the bay of Avalon to spawn, and their numbers are so vast and so closely do they lie, that they form an almost solid mass. Into this I cast an empty hook, and when it is out of sight a slight jerk is sufficient to impale a sardine, which becomes the most active of lures. The sardines do not appear to notice the hook, but the struggles of the live bait alarm them so that they form a solid ring about it. Down it sinks until it reaches the lower stratum of the school, when it will be seized by the watchful bass that apparently cannot resist the struggling fish.

The white sea-bass at Santa Catalina average about forty or fifty pounds; small ones being more or less rare. Specimens weighing eighty pounds have been caught with cast or hand lines; the rod record is fifty-six pounds. In the San Francisco market bass weighing sixty, seventy, and eighty pounds are not uncommon, and doubtless the fish attains a maximum weight of one hundred or more pounds. 
The spawning season is in June and July, the young, which are found in San Diego, Newport, and San Pedro (California) waters, are supposed to be different fish, and are known as sea-trout. The young resemble the adults, but have three or four black or dusky stripes. The fins are darker than in the adult, and the pectoral fin bears at its base a blotch of color more or less distinct. The young, or sea-trout, afford excellent sport with an eight-ounce split bamboo. The angler who desires to try them should engage from the bait-catchers very small sardines or smelt, and use a number two Sproat hook, or any hook of that size.

The white sea-bass swim in long lines, four or five in a column, move leisurely, and impress one by their dignity and beauty. I confess to never having caught one but I was tempted to release it. They rank among the fine table fishes of the Pacific coast, baked white sea-bass of a large size with a dash of port being a savory dish. The misnamed sea-trout are delicious. They should be served whole, broiled or baked. When cut into slices and disguised with some individuality-killing sauce, they might be called by any name and would be quite as unpalatable. 
The white sea-bass is eminently sociable, and if the angler remains quiet, the passing school will merely divide at the anchor rope of the boat: I have inadvertently touched one with an oar. At such a time, looking down, the water appears filled with the splendid fish, which resemble gigantic salmon, and often their utter contempt for all kinds of bait is maddening to the most philosophical angler.

In the Gulf of California a large species of this genus is found, known to science as Cynoscion macdonaldi and called at Guaymas totuava. It is a stouter, bulkier fish than C. nobilis, and exceeds it in size. An old boatman who had wandered up the Gulf informed me that he had caught these fish weighing two or three hundred pounds, but he probably confused it with the Gulf jewfish. There is a record of a fish which weighed one hundred and seventytwo pounds, hence two hundred pounds is possible. A friend who fished for them at San Jorgas Bay, not far from the island of Tiburon, considered them identical with $C$. nobilis, and supposed it was the same fish; but instead of averaging forty or fifty pounds the fish he caught tipped the scales at eighty pounds. At San 
Jorgas Bay there is a very high tide, and behind the flood follow the schools of white sea-bass which have been named by $\mathrm{Dr}$. Gilbert after $\mathrm{Mr}$. Marshall Macdonald, United States Commissioner of Fish and Fisheries. The marked difference between the two fishes that would be noticed by the angler appears to be that in the latter the snout is sharp, while in $C$. nobilis the head is long, snout long and sharp. In $C$. macdonaldi there are about fifty-five pores; in nobilis, seventy or eighty.

The Gulf bass is the giant of its tribe, and can be found in vast numbers on the shores of the east coast, even entering the mouth of the Colorado River. The young are dusky and silvery, and instead of stripes, as in nobilis, have, according to Dr. Gilbert, "coarse black specks along the lower part of the head and sides," there being no disposition to form streaks or bands. It is caught at San Jorgas Bay in April and May, and according to Dr. Gilbert is not known at Guaymas in summer, having probably migrated far up the Gulf, where vast schools of mullet afford an ample food supply. The angler who desires to take this fish will find San Jorgas hot in summer, but pleasant in the 
spring. The settling up the country at the mouth of the Colorado will undoubtedly develop a new field for the angler and sportsman in this section of California or Mexico.

A smaller species of white sea-bass, C. parvipinnis, is known as sea-trout and bluefish along the Californian coast, and has been found from Mazatlan to San Luis Obispo. At Newport, San Pedro, and Avalon it is a valuable fish, taken in nets and often caught by anglers. The largest specimen I have landed weighed about twelve or fourteen pounds, and was about two feet long. It differs in appearance from the other species. Its back is a decided blue, resembling that of the yellowtail out of water. The body is long and slender, with a striking resemblance to its cousin the Eastern weakfish. Altogether, with its vivid silvery belly, blue back, yellow lower fins, it is one of the most attractive of the Southern Californian fishes which fall to the lot of the man with the rod. It is not a common catch, and is taken with small sardines with rod, line, and hooks described for sea-trout. All these fishes are the Pacific representatives of the Atlantic weakfish, or squeteague, $C$. regalis, which every sea-angler has taken along the Atlantic seaboard. 


\section{CHAPTER III}

THE GRAY SNAPPER

"First let your rod be light and very gentle. I take the best to be two pieces." - IzAaK WaLton.

Where keys like emeralds in settings of silver seem to float on seas of lapis lazuli, where channels of turquoise wind in and about the coral reef and soft trade winds sough through palm, mangrove, and bay cedar, there is the home of the gray snapper of the outer reef, the most cunning and gallant fish in its mature condition, that swims in any sea, the most difficult to catch, and one of the most beautiful.

I first became a victim to the wiles and snares of the gray snapper far out on the Florida reef where the last key looks into the west. Here a maze of coral reefs once reached the surface. A mangrove seed came drifting in the stream, lodged in the shallows, took root and grew. To the angler coming from the east, following the sun, this resultant isolated grove forming Bush 
Key, rising apparently from the sea, is the first intimation that Garden Key and its satellites are in sight. Soon other keys appear, low sandy islands, capped with vivid greens - bay cedar and cactus - between which winds a channel so deep and narrow, so blue and beautiful in its clearness, that the angler in this out-of-the-way corner may well wonder by what trick of nature it was formed. It surrounds Garden Key, being in turn hedged by an outer fringing reef upon which the sea breaks; now in soft monotone, or when a norther rises, forming a vast semicircle of foam from which rise weird and terrifying sounds, the grinding and gnashing of the teeth of the reef, as the dead coral heads are rolled hither and yon by the incoming and receding waves.

In the nooks and corners of this channel the gray snapper makes its home, and that it has the love of locality strongly developed, the home instinct if you will, is evident from the fact that week after week, month after month, certain fishes are found in the same places. A certain wreck was a favorite spot where the gray snappers congregated. The old ship had long since disappeared below the surface, but her huge timbers still projected from the sand, forming a cover- 
ing or protected shelf about which the fishes delighted to lie in water from ten to twenty feet in depth. In general appearance the gray snapper resembles the black bass, but is longer and more slender. Its tints are a delicate gray, or green, in the shallows often adapted to the soft mauve of the bottom, or in deeper waters affecting in a general way the more brilliant hues of its surroundings - the reddish and yellow gorgonias or browns of the sea-plumes. Its eye is extremely beautiful; rich in browns with a brilliant flash of blue and at times red; an eye which follows every movement of the angler and is at once critical and expressive.

The first vision of these fishes was my undoing. I never rested until I had taken one, a consummation which came only after days of patient endeavor. I was drifting along shore, looking downward from the rail of the dinghy, when it floated over the old wreck, where, circling slowly about, were a dozen or more gray snappers. They ranged from one to two and three feet in length, well proportioned, graceful, the type of all that is beautiful in a fish. Their movements were dignified and impressive, and there was a suggestiveness of reserve power, as in the black bass, which 
made one eager for the contest. Stopping the dinghy, I anchored and cast my bait, a piece of white conch (Strombus gigas), the favorite grouper bait on the reef, in their midst. It was a striking dainty, standing out in the brilliantly colored water like ivory, and was at once seized by grunts, porgies, angel-fishes, and others, and jerked and bandied about in a manner that would have been irresistible to many fishes; but to my surprise, the snappers paid absolutely no attention to it. I could see every movement, being directly over them, and they were not disturbed in the slightest from the even tenor of their way. I then tried crayfish, breaking the tail shell sidewise and taking the meat out entire, selecting the lower end with its inviting tints of scarlet. Of all baits in tropical waters this is the most alluring and irresistible. Not a fish which I recall, save the barracuda, but can be seduced into biting it, and as it dropped slowly, out sprang a timid parrot-fish and seized it, dashing away followed by the grunts, chætodons, and other courtiers which constituted the train of the gray snapper, that seemed to look with scorn upon the smaller fry so easily deceived. I scattered crayfish bait over the water, arousing the 



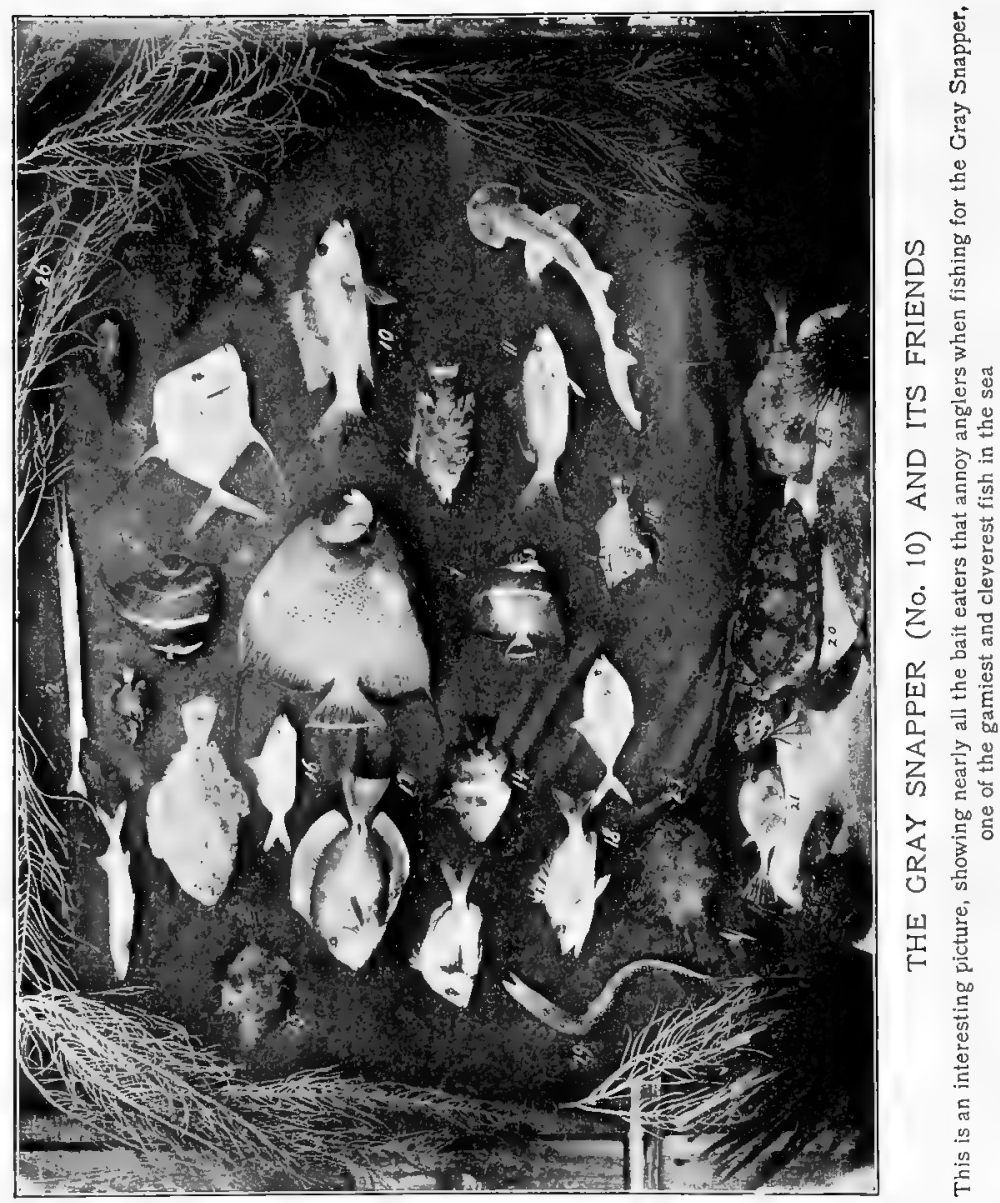


entire community of the wreck to a frenzy in their attempts to reach the bait. Staid old grunts performed miracles of agility, in vying with the parrot-fishes; the great black and white angelfishes, timid ordinarily to a painful degree, dashed at the delicious morsels; a long spotted moray dragged itself from the lower story of the wreck, and I could see by the rapid vibration of their whips that even the crayfishes, which were backed into sandy cells, were discussing the propriety of taking the chances and joining the mêlée.

I had been spending a part of nearly every day upon the reef fishing or floating over the beds of olive-green coral, but now gave up other piscatorial pursuits and devoted myself to the gray snapper. I fished early and late, even at night. I tried them at the flood and quarter ebb, with light lines and dark, with baits whose variety would have arrested the attention of the ghost of Walton. I laid at their shrine young mullets, live shad (Xystaema), gigantic shrimps; caught at great expense of time and patience luscious sea-worms; excavated from the deep mud the soft portions of the rare queen conch clams, - not the base-born bivalve of commerce, but a brilliant, radiant creature of dazzling hues. In desperation, I even 
whipped the glassy water with flies, but in these early days of strenuous endeavor I doubt if I once attracted the serious attention of the gray snappers. Briefly, they ignored me, and the iron was entering my very soul when one day as I lay prone upon the beach, my line in hand, a Sacrata boy named Paublo, who later became my boatman, came wading along with a cast-net slung over his naked shoulders, stopped, followed my line out, and as his bloodshot eyes rested on the snappers he innocently asked why I did not fish for them. There are times when the average angler finds solace in an appeal to high Olympus; whether I did on this occasion, or even added to my humiliation by taking Paublo into my confidence, is immaterial. My reply must have suggested that a doubt dwelt in my mind that a gray snapper could be caught, whereupon my companion proceeded to initiate me into the art. He waded up the beach and with his small bait-catcher, a cimeter-like iron barrel hoop, cut down a number of sardine-like fishes an inch and a half in length, which he called "hard heads." From his shanty near by, upon which roosted three tame asthmatic pelicans, he brought a line of a pale blue color of about twenty-eight strands, 


\section{The Gray Snapper}

soft and pliable, having been well stretched before and after use. To this he attached a leader of very fine and pliable copper wire over four feet in length, and upon the long-shanked 6/o steel Limerick hook, impaled through the eyes six or seven "hard heads"; then with a graceful movement he cast the bait, so that it sank gently eight or ten feet from the wreck where the gray snappers were poising. It had no attractions for the small fry which rushed at it, nosed it, and retired. Then Paublo began a manipulation of the line, imparting to the bunch of silver upon the bottom a tremulous motion. The bait appeared to be a small school of sardines feeding; the simulation was marvellous, and had immediate effect. A large snapper suddenly caught sight of the struggling mass and turning gracefully, moved forward, stopping within an inch of the lure, backing water with its caudal fin, its dorsal rigid, its eyes probably blazing.

Breathing hard, Paublo whispered, "Did yo' see datcher snapper, mawster?"

Again the bait rested, as the suspicious fish backed away and the long wire disappeared in the sand. The snapper now swam around, keeping its eyes upon it, moving nearer and nearer 
until a deep shadow took shape over it and a big dun-colored shark appeared upon the scene, passing over the bait, then stopping as it caught the scent, driving away every living thing in and about that particular wreck.

The lesson was not lost, and on the following day, with a fresh supply of "hard heads," which Paublo cut down for me with his sabre, I again essayed the gray snappers. I fitted my light rod with a new and approved line and the long copper leader, then cast into the magic circle of the gray poseurs. As the bait touched the bottom I worked the line and leader into the sand, imitating the methods of my sable mentor. It was now irresistible, and a large snapper moved at the lure, stopping as did the other, like a Mexican who rides full speed at a stone wall, turns on the instant and touches it deftly. I had witnessed the feat, and the rush and sudden halt of the snapper was a vivid imitation. Its movements were so forcible that the current of water partly turned the bait, which I could see from the high ledge of dead coral rock upon which I was standing five or six feet above. Never was more cunning, more diplomacy, displayed. The fish was fascinated, but it swam over the wire a score of 


\section{The Gray Snapper}

times, turning to scrutinize it, and failing to see it, returning to the bait, swimming about it again and again, a picture of grace and buoyant life. Now it deliberately approached and nosed the lure, lifting the "hard heads" slightly as though searching for the hook; then it swam away, to my despair, and joined the complacent school which poised and circled gracefully near by. But a vigorous movement imparted to the line summoned the snapper again, and with a single low rush of eight or ten feet, it seized the bait, which it shook as might an angry dog, and rose slowly, with fins en charge, while I overran the line. Higher it swam, rising slowly into the empyrean of the waters; then with a sudden gulp it attempted to swallow the bait, felt the wire, and charged the blue waters of the channel to the melody of the reel, that, like the baying hound on fresh scent, repays the hunter for hours of weary waiting.

The rush was out and away into the deep blue heart of the channel, every other snapper disappearing at the charge; and fifty or sixty feet of line were lost before I stopped the fish. Then it was a battle to the finish, with finesse, cunning, and wariness on the part of the game. I appre- 
ciated the delight of the old monarch at the discovery of a new pleasure, for here was something novel in sea angling. It was six or seven three- or four-pound black bass in one, rushing to the surface, breaking the water into crystal spray, plunging down, and bearing against the deadly reel in a long splendid lateral surge. Repeatedly the fish broke away from me, tearing the line from the reel, then dashing in, in an attempt to reach the old wreck, where on rusted iron it might sever the delicate line, - fortunately to be checked by my run up the beach.

In and out, giving and taking, I played this gamy creature; and it played me for twenty minutes, now near shore, again leading me out into the shallows until at one stage of the sport I was waist-deep, literally hanging over the edge of the channel, prepared to swim rather than lose this splendid fish which had unreeled every inch of the all too short line. But the gods which watch over the fortunes of the angler were with me, and I slowly backed the snapper into shallow water, then, having no gaff, and no gaffer to witness my triumph, reeled and led it inshore, holding it at short line, while I admired its beautiful proportions. It rolled its eyes at me in 
protest, I fancied, and it was beyond my philosophy to kill such a rare fighter; so I carefully cut out the hook and released my quarry as Paublo came running down the beach, grains in hand in lieu of gaff-hook. That he questioned my sanity I have no doubt, but that was not all.

"Why, mawster," he exclaimed, "datcher snapper gwine tell all de res'. Yo' ain't gwine to git no mo' fishin' dis day." Which was true for many a day at that spot.

But I was satisfied. I had outgeneralled and caught what must have been a twenty-five-pound snapper, at least Paublo, who saw it swimming off, placed its weight at nearly twice that figure, and when I pressed him for logical reasons for his assumption, he said it was "de scales on de snapper's back dun tole him."

There may be a difference in the game qualities of gray snappers in different localities. The deep-water specimens in fifteen or twenty fathoms are caught much easier, and at Marquesas and Key West I took them in shallow water with crayfish, when sardines or "hard heads" were not to be had, but always found them thoroughly game. Even the small fishes from two to four pounds afforded excellent sport, 
readily taking crayfish. All were cunning, and well deserved the name of sea lawyer.

The gray snapper, Lutianus griseus (Linn.), has a wide range, having been observed as far north as New Jersey, though it is not a common visitor, and as far south as Brazil, ranging east to the African coast. At Bermuda it is common and attains a large size, individuals from fifty to sixty pounds having been caught near Hamilton by friends of mine, and I have heard of larger specimens. The largest gray snapper I took on the outer Florida reef weighed thirty pounds, and this was exceptional, the average weight being from seven to fifteen pounds.

I believe with the gray snappers there is a certain but limited movement into deeper water in the winter months. In summer large individuals are frequently found about mangrove roots in from five to ten feet of water. Along the coast of Florida, the spawning season is from about June I5 to August 15. The young are found almost anywhere, as gamy as trout, I discovered, and among the most attractive and interesting fishes of the reef from the fact that they would allow me to approach so near that I could almost touch them. 
The fact that the gray snapper affects comparatively shallow water makes it especially available to rod fishermen. It frequents old wharves and similar places. It is difficult to describe the color of the living snapper. I have taken individuals showing great variety of tints, but, as a rule, the deeper the water the more brilliant the coloring. Some fishes are a dark greenish hue, the centre of the scales showing a burnished black, the lower portion being a reddish coppery hue, very brilliant, giving the entire fish a suggestion of red golden bronze. Others, and particularly large specimens, taken by me at Garden Key, where the bottom was gray sand, were almost pure gray, suggestive of the specific name griseus given the fish by Linnæus.

An interesting and very gamy snapper, a valuable food fish, at nearly all the West India Islands and Florida keys, is known as the dog snapper (Lutianus jocu). Its habits are similar to those of the gray snapper. The latter is at the head, so far as game qualities are concerned, of a large group of snappers, comprised in the family Lutianidae, and is the largest, but its many relatives - and the famous red snapper, Lutianus aya - afford excellent sport on the reef, 
and the red snapper as far north as Fernandina. The latter is a deep-water fish, found at various points in depressions in the bottom, and is not available for the rod unless one wishes to reel in a fish in water from seventy-five to two hundred feet in depth. With the hand or cast line it proves a hard-fighting and gamy fish. I have had excellent fishing for the red snapper north of Middle Key, Florida reef. The line was rigged with a heavy sinker, the hook with a strong six-inch leader being two or three feet above it, the reason for which was that if the sinker entered coral or gorgonias, the bait would swing clear above. At various points along the Gulf coast off Florida and off Fernandina, the mouths of the St. Johns and St. Marys, redsnapper banks are found, being well known to local and professional fishermen. The so-called red-snapper banks are met with all along the Gulf coast around to Texas and beyond. The "banks," which are really depressions in the sandy floor of the gulf, range in depth from ninety to two hundred feet. On the outer reef conch was a favorite bait, but the fish are by no means epicures, and fish bait is the ordinary lure. Off Middle Key fish were found in spawn in 


\section{The Gray Snapper}

May, but I never saw a young red snapper at this point. On the upper coast Silas Sterns has found them with well-developed ovaries in April, May, June, and July.

On the reef about Marquesas, between Key West and Tortugas, and at the latter key, I have taken large specimens of what the fishermen called the green snapper, Lutianus analis (Cuvier and Val.). It has much the-range of the gray snapper, and is a hard-fighting fish, attaining forty pounds, though I recall but one fish of this size, the average being much smaller. It is a very attractive fish, richly colored, the general tone a dark olive-green, but subject to much variation, red, blue, purple, rose, and even scarlet being conspicuous colors in its make-up. The iris is brick-red, the eye large, the head larger than in the gray snapper. The fins are also red in color, and at times the fish appears to be spotted blue, red, and white with indistinct horizontal bars and a black spot near the tail; again it is severely olive above and white below. The dorsal is often beautifully tinted, roseate at its base, golden green at the tips - altogether a radiant creature, yet lacking the grace of form of the gray snapper. It is a valuable food fish 


\section{8}

\section{Big Game Fishes}

at Key West and Porto Rico. It spawns in July and August and it is said to school; but I have never seen such propinquity in the sense of schooling mullets, jacks, or other tropical schooling fish. Snappers, in my observations, were always seen together; that is, where there was one, ten or fifteen would be observed in the immediate vicinity, perhaps poising, or moving slowly about, never conveying the impression that there was a school - rather a community, as they have the home instinct strongly developed, and, like all snappers, live in certain localities, remaining there during the day, but wandering abroad at night, like many tropical fishes, to feed in the shallow lagoons or flats, where they were never found during the day.

The habit of night feeding in shallow water was very marked at Garden Key, so much so that when it was necessary to catch rare fishes we invariably hauled the seine in the lagoon between ten and twelve o'clock at night, always taking many forms which were never seen there at other times. There was one drawback - large sharks and sting rays were particularly addicted to night strolling, and frequently became entangled in the nets. 
Of all the game fishes of Florida the snappers afforded me the most sport, as they were essentially gamy at all ages and sizes. The small specimens, weighing from two to six pounds, often found in the shallow waters of the lagoon, were the trout of the reef. In one locality, where a key had been battling with the hurricanes for centuries, the great gales had swept the key away from the roots of the mangroves, leaving many stumps isolated and completely submerged. Anchoring the dinghy near these shelters, and casting with a heavy trout rod, using crayfish bait, rare sport was always had. The snappers lived among roots with a horde of other fishes, and would rise as soon as the lure sank a few feet, not having the discretion and coyness which marked or characterized the adult snapper of this region.

The snapper family is very large, including twenty genera and about two hundred and fifty species, nearly all of which have a high economic value; and wherever they can be taken in water about twenty feet in depth, typify all that commends itself in a true game fish. In American waters alone, according to Dr. Jordan, there are about fourteen genera and thirty-five species; but 
including Porto Rico, now an American colony, the list would be larger. Among the small snappers, resembling the gray snapper, is the schoolmaster, Lutianus apodus, easily recognized by its reddish brown and orange colors and whitish stripes. I have taken twelve-pounders on the edge of a little channel near Bird Key, and have seen individuals on the edges of the channels which were doubtless much larger. As a hard fighter and vigorous fish it is unexcelled.

Another gamy snapper is the red tail, Lutianus synagris (Linn.), and seen directly from the water it is one of the most beautiful of all fishes. As it comes in on the line after a vigorous play, it appears olive-hued; then as it reaches the surface and the sun plays upon it, rose, scarlet, silver, gold, deep maroon, and almost every color flash and blend to add to its beauties. Even the lips are vivid red, its eye or iris a flame of scarlet, marking the fish as a fitting companion to the gorgeous parrot and angel fishes of the reef. 


\section{CHAPTER IV}

\section{THE LEAPING TUNA}

"First be the fisher's limbs compact and sound, With solid flesh and well-braced sinews bound;

Let due proportion every part commend, Nor leanness shrink too much, nor fat distend."

OpPIAN must have had this acrobat of the seas in mind when he pictured the physical requirements of the fisherman, as he who would try conclusions with the leaping tuna, with the rod, must be in good physical condition, and be skilled in the use of the rod and reel.

Tuna angling is purely a modern sport which I suggested ten or twelve years ago at the island of Santa Catalina, California, and, like many manly sports, it flashed into popularity and almost world-wide fame. The tuna is the horse-mackerel, the giant of the mackerel tribe, the doughty head of the family Scombrida; an ocean wanderer, a pelagic swash-buckler of the sea; now feeding upon bluefish, menhaden, or herring in 


\section{Big Game Fisbes}

the Atlantic, gorging itself with the great flyingfish or squid in the Pacific; everywhere a terror to the smaller denizens of the deep. For centuries it has been caught in great nets in the Mediterranean Sea, on whose shores it is considered a dainty; and from the mouth of the St. Lawrence to Cape Cod it is more or less common in summer and occasionally harpooned, its crescent-shaped tail being seen on many a longshore fish house from Cape Breton to Swampscott, a talisman of good luck.

The fishermen along the coast of Nova Scotia, especially in the vicinity of Cape Breton, the mouth of the Myra River, and the region about Sydney, have long been familiar with the big fish which they call the "albacore," and which chases schools of herring into the great bays in July, August, and September, often playing havoc with nets. From inquiries among fishermen, I believe that the Atlantic fish averages much larger than those of the Pacific coast, entire schools of which often range from eighty to one hundred and fifty pounds. In the Mediterranean, five hundred pounds is considered a large fish, and two hundred, according to Kingsley, is the average. At Cape Cod, near which they are often har- 
pooned for the oil, Captain Atwood states that "the average size is about eight feet in length." According to Goode, the fish attains the weight of twelve or fifteen hundred pounds; Cetti, the Italian naturalist, gives its maximum weight as fifteen hundred pounds. Dr. Storer describes one weighing one thousand pounds, which was fifteen feet in length, harpooned at Cape Ann in I $85^{8}$; and Captain Webb in 1878 killed thirty in Gloucester harbor, which averaged one thousand pounds each. Dr. G. Brown Goode records one weighing three hundred pounds, which was harpooned at Minot's Ledge, August 16, I856; another, nine feet long, weighing six hundred pounds, taken at Marblehead in the same year. In 1856 a horse-mackerel was taken off the town of Lynn, Massachusetts, which weighed one thousand pounds, was ten feet in length, and six in girth. It was harpooned and killed by three men in a dory, and the specimen was secured and presented to the Lynn Natural History Society by Dr. Joseph B. Holder, its president, father of the author. This was the first tuna ever seen in a scientific institution in America. In July of this year Dr. Holder reported another fish, nine feet in length, and a third, taken at Nahant, almost 
as large, nearly one thousand pounds in weight. Dr. Holder reported to the society that these fishes were very plentiful in Massachusetts Bay in 1850 , and that he had measured several which were ten feet in length. Another fish taken at Bass Point, Nahant, was examined by Dr. Holder and Louis Agassiz, who were then investigating the fauna of the bay; it was found to measure ten feet in length; girth, six feet; weight, six hundred and fourteen pounds. The discrepancy between weight and length in different fishes is one of the interesting features in controversial angling, the weight being a question of condition, not length.

On European shores the horse-mackerel or tuna reaches the Lafodin Islands in latitude $69^{\circ}$, and can be found well up on the Newfoundland coast in summer. It appears at Provincetown, Cape Cod, in June, leaving in October, and is harpooned for its oil, a large fish producing twenty-three or twenty-four gallons. Regarding the range of the fish in the Atlantic, Kingsley says: "Mr. Matthew Jones of Halifax, Nova Scotia, writes, "The tunny is very common on the eastern coast of Nova Scotia in summer, and is known to the fishermen as "albacore." The 
THE LEAPING TUNA 



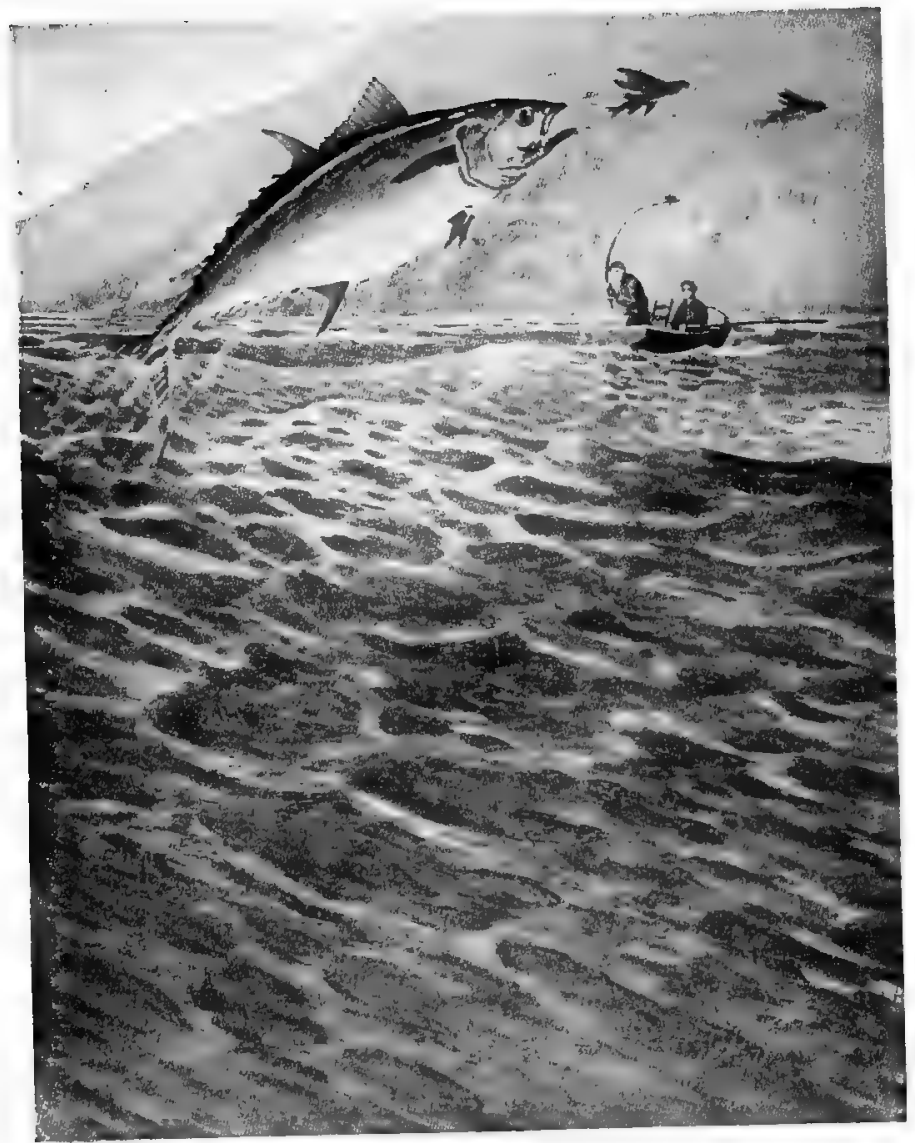



Rev. Ambrose informs me that it regularly visits St. Margaret's Bay every summer, several specimens being taken and rendered down for oil. They were particularly abundant in 1876 . They are never seen in the Basin of Minas."

That the Atlantic species, so far as seen, are mainly giants is shown by the condition of nets after their visits, Captain Atwood describing an eighty-yard net which had forty-seven round holes after a raid of these fishes; the tunas had gone through it as through paper. In the Canadian Fishing Report of 1863 Dr. Fortin states that the fish is "quite abundant in the Gulf of St. Lawrence, especially the Bay of Chaleur and off Gaspé, and also in the straits of Belle Isle and Blanco Sablon Bay. It is also taken at Caraquette." Dr. Fortin adds, "The fishing is quite exciting, although tiresome and requiring a good deal of skill (steel hooks are used, tied to solid lines), as in the efforts to escape they pull with such violence as to endanger the lives of the fishermen by dragging them overboard." In the Mediterranean, the catch is entirely by a vast net, known as a madrague, which is very successful at Favignana, where as much as seventy tons of the fish, here known as the tunny, is taken 
at once. Attempts have been made to take the tunny in these waters with rod and reel, but so far have failed. The game was found in great abundance on the Italian coast, but for some reason it would not bite.

I first conceived the idea and fostered the hope of catching a tuna with a rod when measuring a giant specimen which hung in Fulton Market some twenty years ago. It had been harpooned in Massachusetts Bay, was about eleven feet long, and weighed in the neighborhood of one thousand pounds - a type of all that is ponderous and massive in the true fishes. The following year I confided my ambition to a professional fisherman, a man of great intelligence, with whom I often fished at Ogunquit, Maine, and made various trips to the offshore banks near Boon Island Light in quest of the game which he assured me was there; but though I fished with patience, trolling and anchored, tried all kinds of bait from moss bunkers to live pollock, I could never lure the Atlantic tuna, and indeed never saw one, though my companion related tales of monsters which came around his dory, feeding almost from his hand, when fishing for dogfish. In these waters the tuna never or rarely was seen, 
as it did not leap for its prey, there being no flying-fishes. In 1887 or I 888 I began to fish the waters of Santa Catalina, and here saw the same horse-mackerel or tuna, now feeding on the California flying-fish, to capture which it sprang into the air in magnificent bounds; hence I called it the leaping tuna, to distinguish it from the nonjumper of the Atlantic. To take so large and powerful a fish smooth water was a desideratum, and so far as known, Santa Catalina, California, is the only locality where the fish has been taken with rod and reel; and even here the fishinggrounds are limited to about four miles of coast in the lee of the island mountains, which afford several open bays, generally smooth, the wind blowing only part of the day, thus giving the angler conditions absolutely perfect, without which tuna fishing, would be impossible and extremely dangerous.

It would weary the reader to detail my efforts to catch a tuna. I frequently hooked them, lost tips, rods, and lines, which were cheerfully offered at the shrine, and told the stories to incredulous listeners, all to no purpose. Horace Annersley Vachell, in his "Life and Sport on the Pacific Slope," who has written a delightful account of 
this sport, thus refers to this period of probation:-

"The following excerpt, from an article written by my friend Charles F. Holder, is worth quoting :-

" "The activity of the tuna is only comparable to that of the tarpon. I have seen them leap ten or more feet into the air, while they have been known to jump over the boats in pursuit of them. Sportsmen from the East have devoted weeks to this fish, hoping to win fame and honor by taking one on a rod; but so far the tuna has harvested the rods, reels, and lines, and is still master of the situation." "

At this time no large reels were obtainable. The rods were jointed and inadequate, and I recall one angler who devoted the entire season to an effort to take the elusive tuna. Finally a tuna was caught by Colonel C. P. Morehous, who used a reel made for the purpose, and immediately the pastime took its place, with that of tarpon fishing, among the most exciting of American sports. The advantage California has over other localities is that the tuna, being an oceanic fish, rarely if ever comes inshore nearer... than seventeen or eighteen miles. It is very 


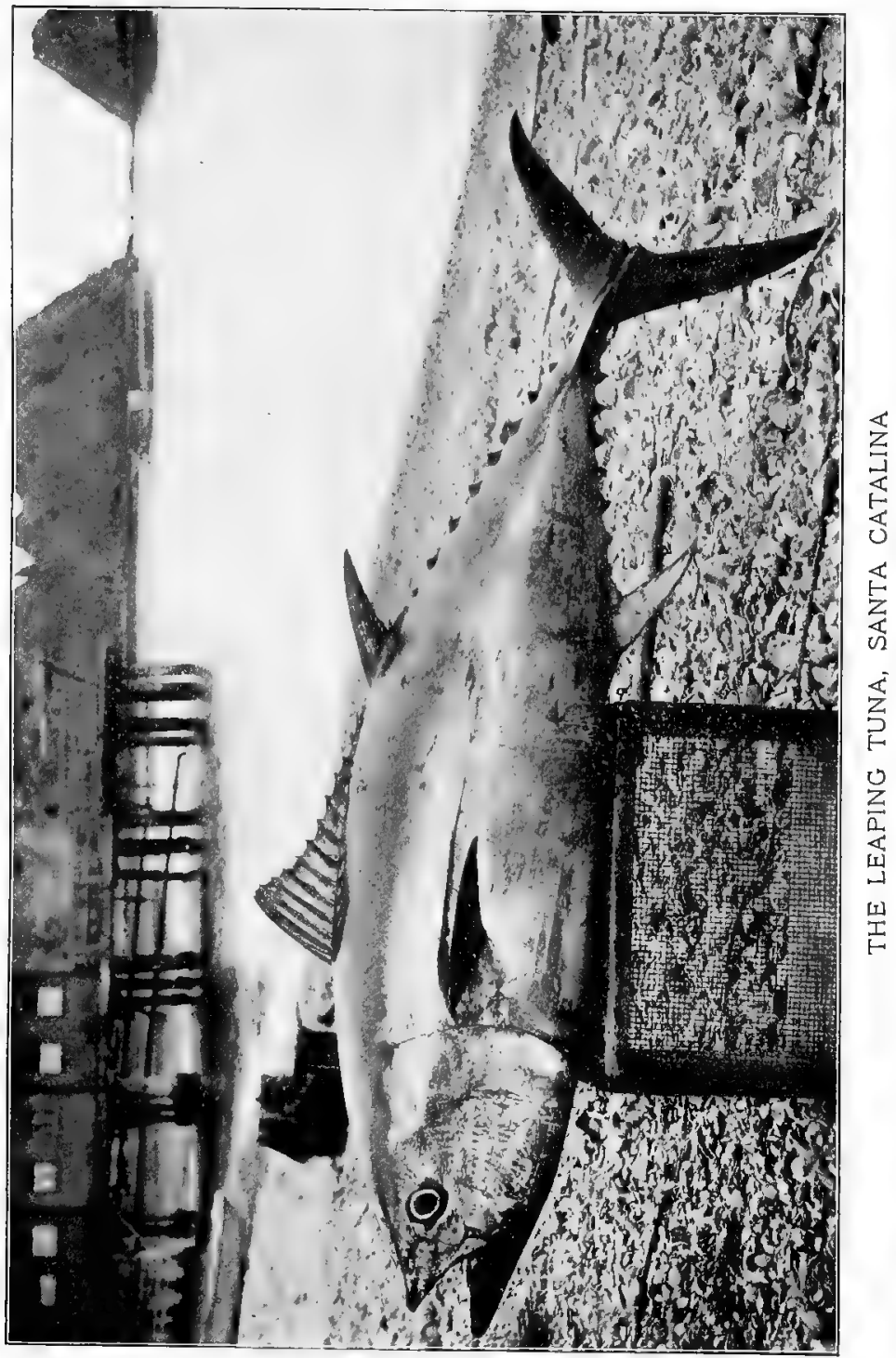




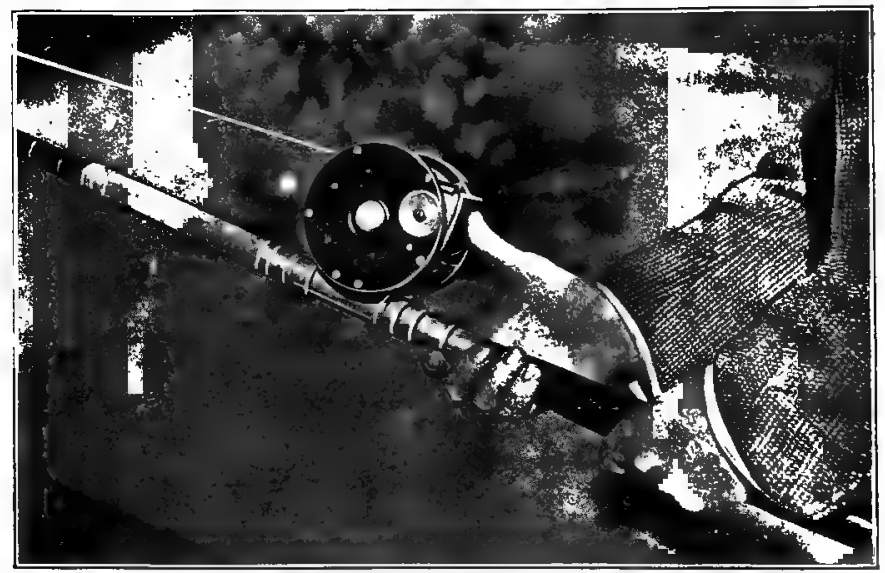

Figure showing Tuna reel and the position of, the thumb when using the leather pad brake. The silver disk on the reel indicates the patent brake to prevent overrunning during a rush. Above the reel seat is seen the cork grip for the left hand

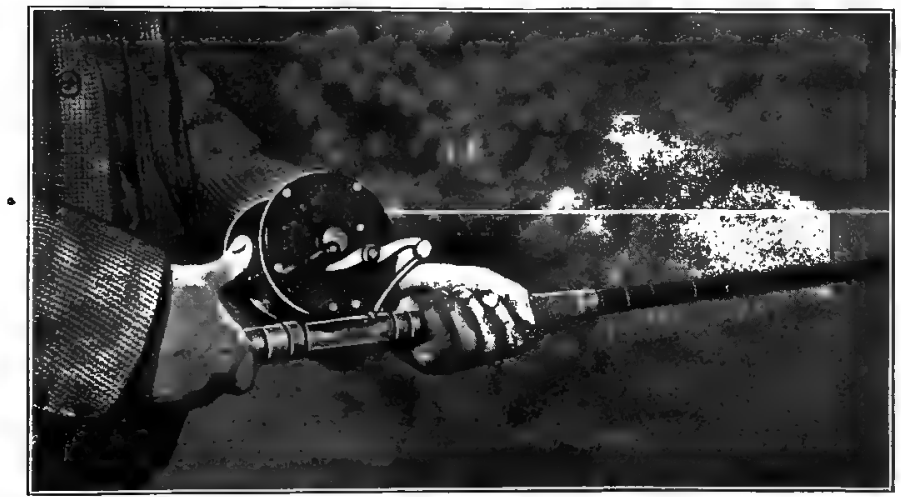

Tuna or Tarpon reel, showing position of hands "waiting for the strike," - left hand grasping the upper cork grip, the right thumb pressing gently upon the leather pad brake 
rarely seen near the mainland of California; the island mentioned is about twenty miles out to sea, and a natural feeding-ground of the fish in summer, the alert tuna using the open bays into which to drive its victims, the California flyingfishes. The tuna boats of Catalina Island are designed for the purpose, and are mainly stiff, broad-beamed launches, built for three persons: two anglers, who sit side by side in chairs facing the stern, and the boatman, who is helmsman, gaffer, and engineer of the three or more horsepower gasolene engine. Overhead is an awning, which is raised by the gaffer when the strike comes, and each boat has a flag bearing the figure of a tuna, which is thrown to the breeze the moment a fish is hooked, so that interested spectators ashore can tell several miles away whether good luck is in the wind.

There are two essentials in tuna fishing, a cool, intelligent, and practised gaffer, and perfect tackle; with these the novice can be assured that the responsibility for the loss of the fish rests on his own shoulders. As to tackle, I recall one angler who made a practice of never using the same line twice; at the end of the day he presented it to the boatman. This is unnec- 
essary, as a good line will last a season through if well used, but it illustrates the fact that some anglers take no chances. The reel most in vogue is made especially for the purpose; it is as well put together as a watch, and costs from thirty dollars upward. It is of rubber and silver, and is so perfectly adjusted that a whirl of the handle will cause it to run some time. It must have a capacity of eight hundred feet of number twenty-one line when wet. It should have a melodious click, and a drag to prevent over-running, and attached to the lower or upper cross-bar there should be a leather pad lined with moose hide. This is the brake par excellence, used by pressing it upon the line with the thumb, and it should never be used unless the line is wet, as the friction will burn the line. The reel should always be lashed to the rod. As to the line, there are several makes in use. What is known as twenty-one cuttyhunk and one or two others especially made have all been tested on the tuna grounds. One particularly good line is of Irish linen, hand laid; the twenty-one tested to pull forty-two pounds dead weight; the twenty-four, forty-eight pounds; the eighteen, thirty-six; the fifteen, 


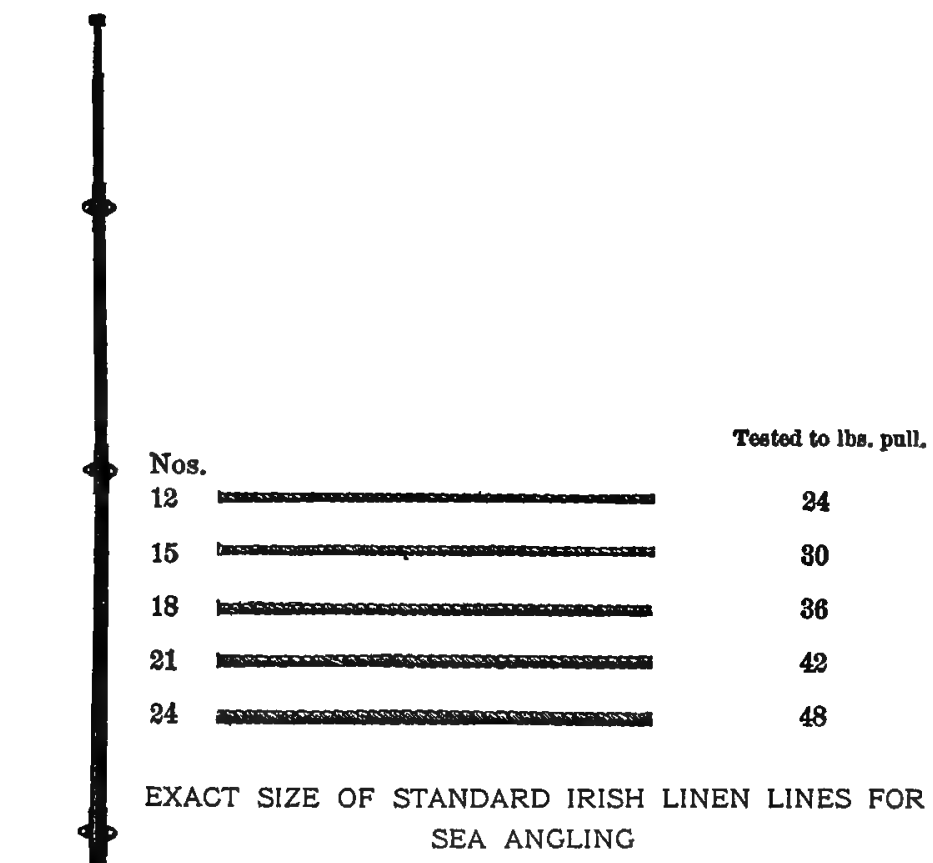

No. 12 , fish up to 20 pounds

No. 15 , fish up to 30 pounds

No. 18 , fish up to 60 or 100 pounds, and Tarpon

No. 21 , Tuna, Black Sea-bass

No. 24 , when heavy lifting is refused, as Jewfish, etc. 

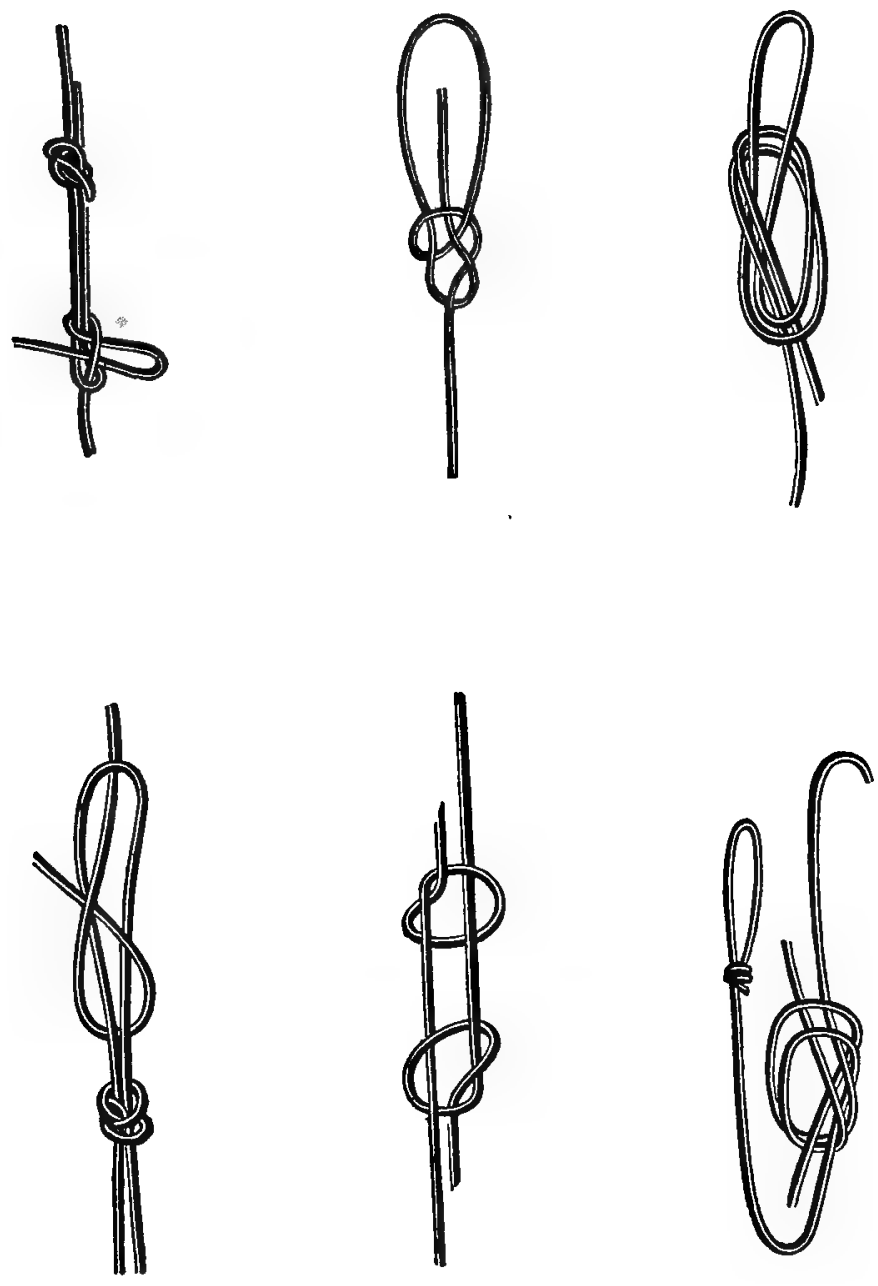

ANGLER'S KNOTS

(See chapter on Leaping Tuna.) 
thirty pounds. A line of this quality is indispensable. By such a thread a tuna towed me in a heavy boat ten miles, the perfect line saving the day. For practice a number twenty-four is commended, but after the novice has landed a tuna a number eighteen line is sufficiently strong for a cool hand. A new line should always be soaked before using and stretched for a day previous to use, and allowed to dry in this way. I am aware that an opinion prevails that this takes the spring from a line, but I have always made it a practice. In the words of an expert, "This sets the lay of the line, and not only lessens the liability of kinking, but helps to even its strength." This will be appreciated by those who have watched the mental anguish of a brother angler whose line has kinked while the fish were biting.

The selection of a rod is important. A poor rod, or a very cheap one, is an impossibility. Large fish have been taken on small and light rods, but the well-equipped angler will find solace and comfort in going into the fray with perfect tackle. A good greenheart rod weighing twenty-five or twenty-six ounces, with one long tip and agate guides, seven or seven and a 
half feet long, will be found equal to the demands upon it. The tip must not be so pliable that a heavy fish cannot be lifted, nor so stiff that the rod will not bend; a happy medium must be selected. A split bamboo rod, costing from twenty to thirty dollars, is eminently adapted to the sport. One of the best rods for the purpose has a patent hard rubber butt into which the tip fits, the rod really being one piece with a short butt. It is of noib wood - a species of greenheart of great tensile strength. This rod has heavy silver mounting, double bell guides, is six feet nine inches long, and weighs twentysix ounces; with an extra tip the angler is well equipped, though he should never go tuna fishing with a single rod. In the equipment of the line, especially in the question of knots, every angler has his fancy. My own preference is for a plain bowline in fastening leader to line or swivel. I have heard many arguments against it, but have never had the knot wear or chafe off in the heavy work of tuna fishing. To those who do not care for the bowline there are others well known to the angler. Number I shows a simple knot for tying leader to line, the ends being merely cut off after tying. Num- 

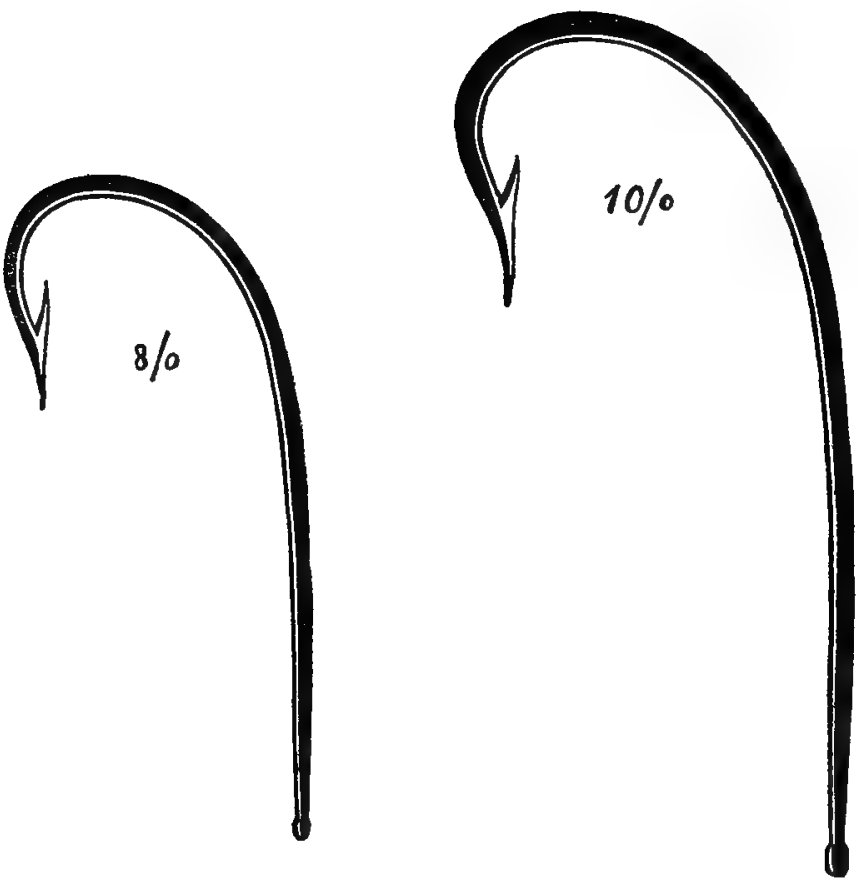

8/0. YELLOWTAIL 10/0. TUNA AND BLACK SEA-BASS

Needle-eye

TUNA OR BLACK SEA-BASS HOOKS, SHOWING SIZES USED BY THE AUTHOR 


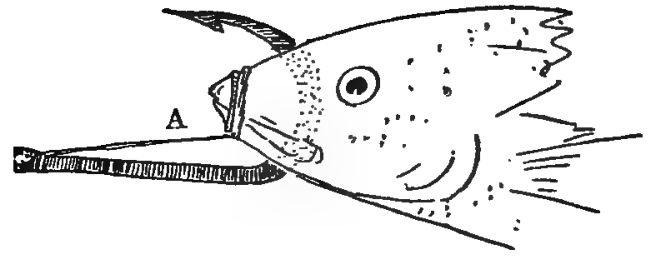

Ordinary way of baiting Tuna hook with flying-fish. $A$, wire fastening the mouth. The Tuna strikes at the eye

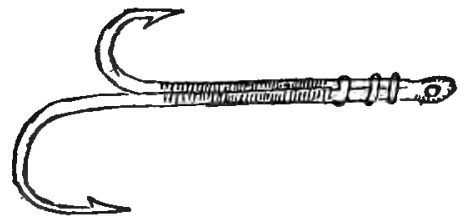

Hook suggested and used by Col. C. P. Morehous, Pasadena, Cal.

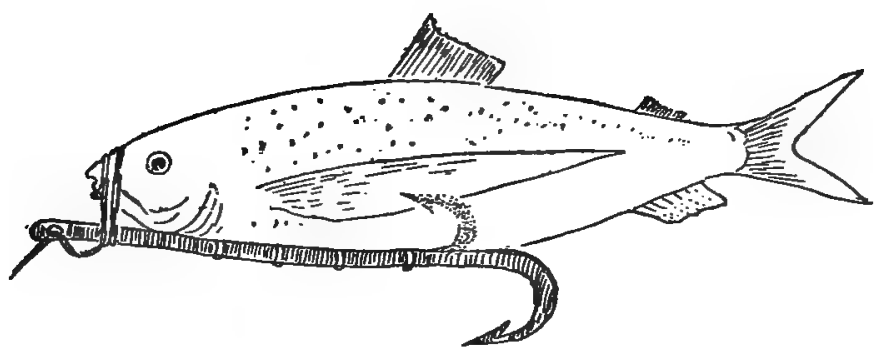

Morehous Tuna hook sewed upon ventral surface of 10-inch flying-fish 
ber 2 is for a similar purpose. Draw the knot tight and cut the ends. Number 3 is a good knot for fastening line to the swivel, one easily made and as easily unfastened. Number 4 is an excellent knot to conjure with, giving easily to facile fingers. Number 5 shows a knot easily untied by jerking the end of the loop.

The leader, or snood, in tuna fishing should be six or seven feet in length, of phosphorbronzed wire, and the next ten feet of line should be doubled. This will save many a fish, as in a long struggle the line is liable to chafe off on the back of the fish. To the leader is fastened a Van Vleck hook, supposed among tuna experts to be very killing; but a ro/o O'Shaughnessy is equally effective - a small hook for so large a fish. There should be at least three strong brass swivels between hook and line. The bait is a large flying-fish, which is hooked in various ways according to fancy. The tuna almost invariably strikes at the large black eye of the flying-fish, hence many hook the bait through the lips, barb up, and sew up the mouth to make the fish run smoothly. Others sew the hook along the body and have the point 


\section{Big Game Fishes}

project through the abdomen near the vent, while others again use two hooks, one with a long shank-a method which has nothing to commend itself. Another hook, suggested and used by Colonel Morehous, has a shank six inches in length and is double; that is, two hooks are welded together, back to back, one a little lower than the other [see Fig.]. In baiting this hook the long shank is laid along the belly and sewed to the fish, one hook penetrating the body near the vent, the other projecting. The mouth of the fish is sewed up and fastened to the shank. This is a very killing arrangement, and in view of the fact that the novice misses about eight strikes to one catch, it is admissible; but I am an advocate for the plainest and simplest tackle on the ground of fair play to the game. The use of two separate hooks, one in the head and one in the tail of the bait, often used, is an unpardonable sin, as nearly all the fish come in foul hooked, - one in the mouth, and one in the belly or side, - a result which can but totally destroy the pleasure of a capture after a four or five hour struggle with the noble fish. In a word, the tuna should be approached with all the advantages on its side. 
Such is the equipment, and the angler will do well to have several lines, at least two reels, and half a dozen baited hooks ready for immediate use, as it is the unexpected which invariably happens in tuna fishing, as in anything else. I have found besides duplicate rods a fishing valise of value. This contains the reels, lines, hooks and leaders, extra swivels, wire, pincers, pocket oiler, extra guides, chamois for the reel, compass, extra gaffs, hook; knife, rule, court-plaster, etc. At Avalon every boatman provides the wellequipped rods, but the angler who loves fishing as an art and a part of his life worth living, will own his tackle. The delights of angling are in a general way threefold. There is, first, the anticipation which lasts and is a solace through long winter months; then the possession of tackle is a delight in itself; and finally the catch. Of these the tackle - the old rods and reels - to talk over in the out season, to my mind, rảnk equally with the others. I retire my rods after adequate service full of honors, and as they hang on the wall, pensioned off, live over the incidents in their lives so deeply engraved on their responsive hearts. One, as a friend remarked, "is not much to look at," but beneath its scratches and 
weather-worn appearance lie a tenacity, spring, and strength worthy a rest for the remainder of its life, as there is "life" to a rod which departs in the course of time. With this rod I played a fish four hours; later, it landed a three-hundred-and-fifty-pound bass in the hands of a friend, and then was invalided. Another slender split bamboo trout rod, on the retired list, brought in after an hour's struggle a thirtyfive-pound amber-fish; and so on, one might go through the list of old rods which have a personality to the angler who really enjoys the sport in all its details.

It has been my fancy to experiment with comparatively light rods, and when fishing to use as nearly as possible a rod adapted to the fish; that is, so light that in the balance of chance the game has a decided advantage. In fishing for tuna, tarpon, and the black sea-bass, the trio which are the tiger and elephant hunting of the angling world, the temptation is strong to use robust and short rods; yet I took a one hundred and eighty-three-pound tuna with a three-jointed rod; have caught large yellowtails and sea-bass on a black bass rod; and a ninety-pound tuna, that threw us into the sea a mile from shore, 
was killed with a delicate jointed greenheart rod, built and intended for yellowtail. Even Walton assumed an apologetic air when he approached a big fish story. "Because you say you love such discourses as these, of rivers, and fish, and fishing, I love you the better, and love the more to impart them to you. Nevertheless, scholar, if I should begin to name the several sorts of strange fish that run into the sea, I might beget wonder in you, or unbelief, or both, and yet I will venture to tell you a real truth."

So with the leaping tuna. If I should relate the experiences I have been witness to, I should surely "beget wonder" in the reader, if not "unbelief," so extraordinary are they, so seemingly impossible; and it is perhaps fortunate for this truthful history that there are forty or fifty "blue button members" of the Tuna Club who have survived their initiative, the taking of a one-hundred-pound fish, all of whom have had experiences equally remarkable, which make up the chronicles of this organization devoted to sea angling and the protection of game fishes.

The tuna moves north and south, in or out, with more or less regularity. It is due at Santa Catalina from the $5^{\text {th }}$ of May to the $5^{\text {th }}$ of 
June, generally soon after the arrival of the flying-fishes. For weeks perhaps anglers from all over the country have been waiting, vainly fishing, when suddenly in the offing a black, arrowlike object is seen to rise into the air, A splash, a rush of waters, dozens of flyingfishes radiating like gigantic dragon-flies in every direction, and the tuna season has begun. Every boat and angler is in a short time in the midst of the fray, and many strikes there are, but few are taken.

As to the time for tuna fishing, there is a difference of opinion. Some anglers are on the ground at daylight; others follow the schools at all times. I have had better luck; that is, more strikes, early in the morning on a rising tide, but the tuna is fickle game. At times it bites vigorously, then will cease without rhyme or reason, during which exasperating period schools of hundreds may be passed and crossed, the fish absolutely ignoring the various devices of the angler. The fishing-ground may be said to be from the point of Avalon Bay to Long Point, a distance of four miles, and from fifty feet to a mile offshore. The tuna is a strategist, and this shoreline, with its numerous open bays, the mouths 
of cañons, constitutes a series of traps, into which they can charge the flying-fishes; and when they are feeding, they can be caught on the edge of the kelp within twenty feet of the shore. The tuna does not travel in a single large school. That they arrive in a body is doubtless true, but when once on the ground they divide into small squadrons of from fifty to two hundred and are apparently preparing to spawn, playing on the surface, and on calm days, which are the rule in spring, they can be seen for a long distance, the spike dorsal out of the water, followed by the upper lobe of the sharp crescent tail. They move in the general form of flying ducks or geese; a large triangular figure, with one or two large fishes perhaps in the lead. They are so tame that a boat can approach within fifteen or twenty feet of them before they sink, and it is an easy matter to follow and circle the school.

In fishing we are on the beach at daylight. To the east great bands of vermilion are piercing the sky, and the entire heavens are blazing with a rosy light, the advance guard of the sun that presently comes up over the Sierras on the mainland like a ball of fire. The boatman, who is just in with fresh flying-fishes, reports tunas all 
along shore, and a few moments later we are shoving off, seated in the stern of a wide-beamed yawl. She is rigged with a two-horse power engine, but the boatman rows out into the bay, stopping to fasten on the leaders as we overreel. This accomplished, he rows on while we unreel the entire line to soak it - an essential, as a dry line will burn off under the rush of a fish when the leather brake is applied. We are not out of the bay when a flying-fish is seen coming directly toward us, then another, and still another,

"Look out, sir!" cries the boatman.

Look out, indeed. Two fliers pass over the boat, my companion and I dodging them, catching one, and then, not ten feet from us, a torpedo seems to explode, and the still water flies into the air a mass of gleaming foam. Quickly another rod is taken, the living flier hooked on and cast. We are surely caught unprepared, yet zeee-ee-zee! a swirl of waters, a wail from the steel throat of the big reel, and the game is away. Gone? yes, gone, and if it must be acknowledged, two tuna men, who imagined they were cool under any circumstances, have been robbed of bait and one hundred feet of line, and all in a moment, now sit dumfounded, then laugh at this phase of 
fisherman's luck. Manifestly the tunas could not wait for any lengthy preparation; they came in to meet us; we have met the enemy and we are theirs. The moral is, not to start from the beach until everything is in readiness and to be prepared for a strike the moment the bait is over, and all the time. A school of half a dozen tunas has entered the bay charging the flying-fishes, and is off up the coast, where we follow. Once around the point the tuna ground stretches away from point to point, four miles or more, of as beautiful water as the eye ever rested upon, with high rocky cliffs and blue-tinted mountains to the left, and everywhere as smooth as glass. Tunas are in a short time sighted, some leaping into the air, and as we move down the coast a heavy sea appears to be breaking on the Long Point rocks. But it is merely tunas feeding, each tuna as it rushes creating a whitecap; and as hundreds are seen, the sight is a marvellous simulation of a storm on a sea of glass.

A flying-fish now comes soaring over the ocean a foot above it, and we know that just below is an eagle-eyed nemesis ready to pounce upon it like a tiger. We know that the tuna and its mate are swimming at an angle, canted, or, as 
the boatman says, with a "list," that its big, black, hypnotic eye may follow each move of the flier. The latter has soared nearly two hundred yards and begins to flag; its tail drops lower and lower, then touches the water to beat it furiously, at which there comes a rush of waters as the tuna attempts to seize its game. But the flyingfish in these few seconds of impact has stored a fresh supply of force, or inertia, and now soars away in a slightly different direction, a foot above the surface, the tuna still beneath it, uncertain whether to leap or to wait until the weary victim shall drop into its maw. It is here that we are treated to the lofty leaps of the tuna. If the latter is swimming deep in the chase, it occasionally dashes upward after the soaring fish, often missing it and rising ten or more feet into the air - a magnificent spectacle. Attaining its limit it turns gracefully and drops headlong into the sea. I have seen such a fish strike the flyingfish and send it whirling upward like a pinwheel. Again the tuna will seize its prey in mid-air, as will a man-of-war bird.

While we have been digressing on came the flying-fish, crossing our bait by a lucky chance, or by the strategy of the boatman. We could 
almost feel the premonitory crash; every nerve was tingling with expectation; then twenty feet from the bait there was a rush, the tunas had sighted them, and for several feet they raced along, for there were two (generally the case), hurling the water, arrows aimed at the baits. They had been deflected from the flier, and while the water swirled astern, the cry of two reels rose on the morning air. Vainly the leather thumb brakes were pushed upon the line; the latter slipped beneath it in feet and yards, then one reel became silent, the slack line telling the story of a flaw, or possibly too much thumb power, or a rusty leader. Despite every effort the tuna tore the line from the reel, the boatman backing with all his strength, endeavoring to force sternway on the boat before the line was fully exhausted. Five hundred feet had slipped away and the boat was sliding through the water at a rapid rate when suddenly the line slackened, the game was gone. No, the line was doubling in, and springing to my feet I witnessed a splendid movement of the gamy fish, one which I have never seen repeated. The tuna had turned and was literally charging the boat, el toro of the sea, coming on like a gleam of light, its sharp dorsal cutting the 
water. I reeled with all my speed, knowing that if I was caught on the turn with an unknown amount of slack line, the end might come; but. fifty feet had not been gained before the tuna was within fifteen feet of the boat, then seeing me it turned and was away like an arrow from a bow. The big reel groaned as the crash came, but the brake was thrown off and my thumb played upon the leather pad with rare good luck, with just sufficient force to prevent overrunning. I gained enough line during this spectacular performance to stop the fish at three hundred feet, and held it by the thread of line while it towed the boat out to sea. A mile it took us, now plunging into the deep heart of the channel, to rise again with. throbs which came on the tense line like heartbeats and found an echoing response. I gained ten feet to lose five, then would lose twenty to recover all, and more by vigorous "pumping," as the fish sulked and labored at the bottom of the sea. Suddenly I felt the line humming, vibrating like the cord of some musical instrument as the great fish rose, and as it reached the surface with a mighty swerve that gave the boatman active work to keep us astern to the game, it turned and again charged me. I rose, reeling rapidly as I 


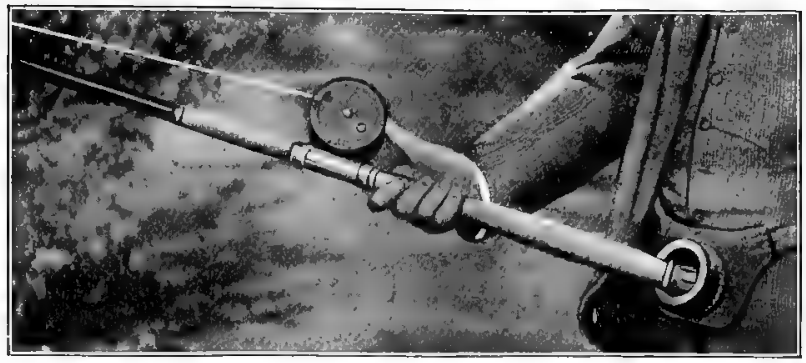

Figure showing size of reel used for Yellowtail, White Sea-bass, and any fish up to 50 or 60 pounds. Right thumb on leather brake: this is the fishing "position," showing also the "butt rest" "when used as a belt

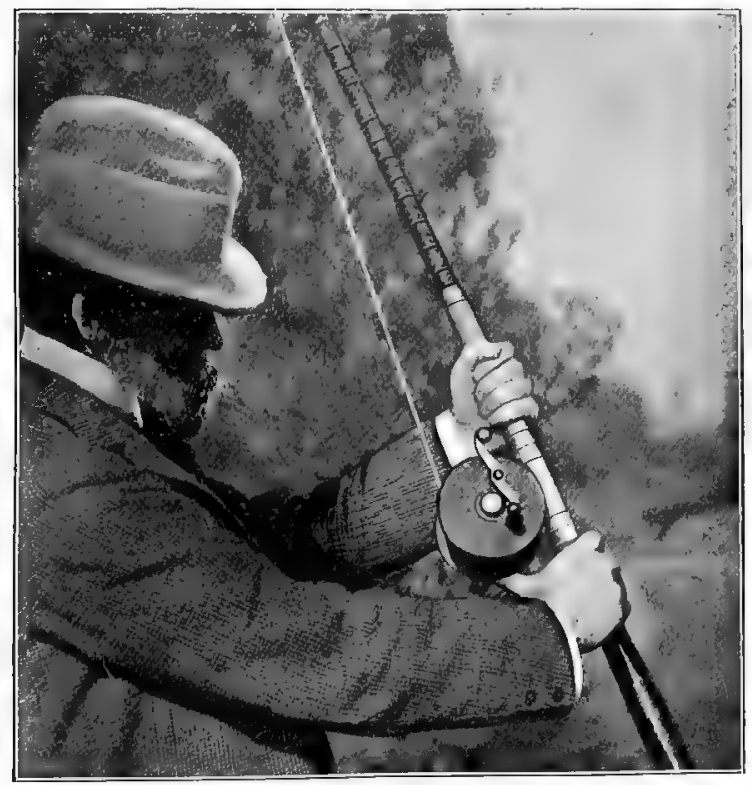

Showing position of the hands, giving a Tuna "the butt." Right thumb is on the leather brake, left hand grasping cork grip 

watched the splendid trick; for trick it was, an attempt to take me unawares, running in on the line to break it if possible in the outrush. Again the fish turned hard by the boat and dashed away, this time inshore, towing us a mile or more, and within fifty feet of the rocks and their beard of kelp where I succeeded in turning it, and now gained so rapidly that I had the fish within a short distance of the boat. The boatman was fingering his gaff, when, with a magnificent rush, the tuna tore from the reel three hundred feet of line, undoing the strenuous labor of nearly two hours. The fish appeared to be seized with a frenzy. It rushed around the boat at long range, plunged deep into the blue water as though searching the bottom for some obstacle upon which to rub the line, then rising with a strange bounding motion which was imparted to the rod, again charged the boat.

For three hours I fought this superb fish, during which it towed the boat from near Avalon to Long Point, then several miles in and out, repeatedly charging, never giving signs of weakening, always bearing away with its full force. At the end of three hours I again brought the fish to within fifty feet of the boat, when it again broke 
away and towed us four miles south, occasionally stopping to rush in, and once carried us out into rough water, towing the boat stern first against the heavy seaway so rapidly that I expected to see her fill; but by sheer good luck I turned the fish, and at the end of four hours brought it to gaff. Slowly it circled the boat and for the first time we saw that the fish was what we had suspected, of unusual size. As it slowly swam along, its big back of a deep blue, its white belly occasionally gleaming as it turned, its finarettes flashing gold, it presented a magnificent spectacle, a compensation for the hardest struggle I had ever made. Nearer it came, then it was turned at the quarter, the boatman's gaff slid beneath, and the big hook struck home. It was a clever gaff, but with a tremendous surge the tuna sounded, shivering the handle in the gaffer's hands, and was away taking the wreck with it. Fortunately I stopped the rush, and a few moments later again had the tuna alongside. This time a new gaff held it, the gamy creature, never conquered, never discouraged, lashing the water, hurling it over us, a last defiance. A nervous gaffer would have lost the fish at this stage, but the boatman held fast, and stepping 


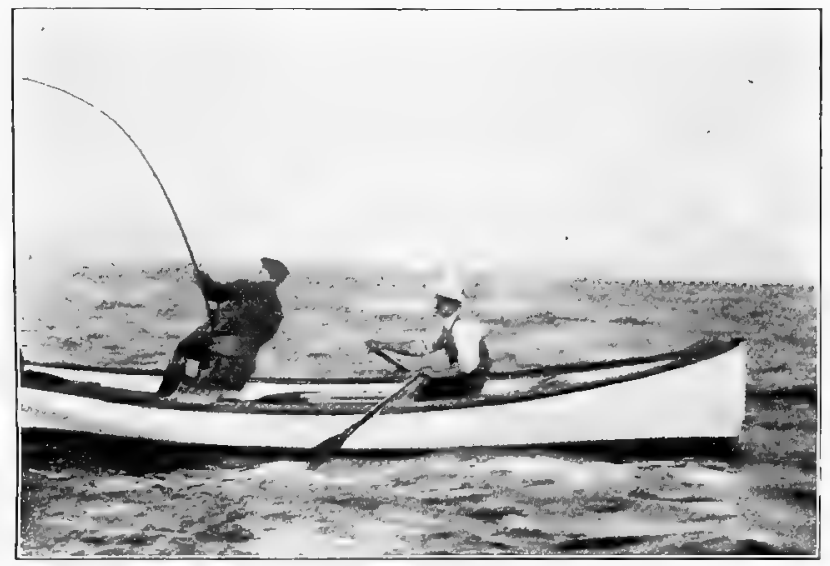

Playing a large Leaping Tuna from the boat used in California

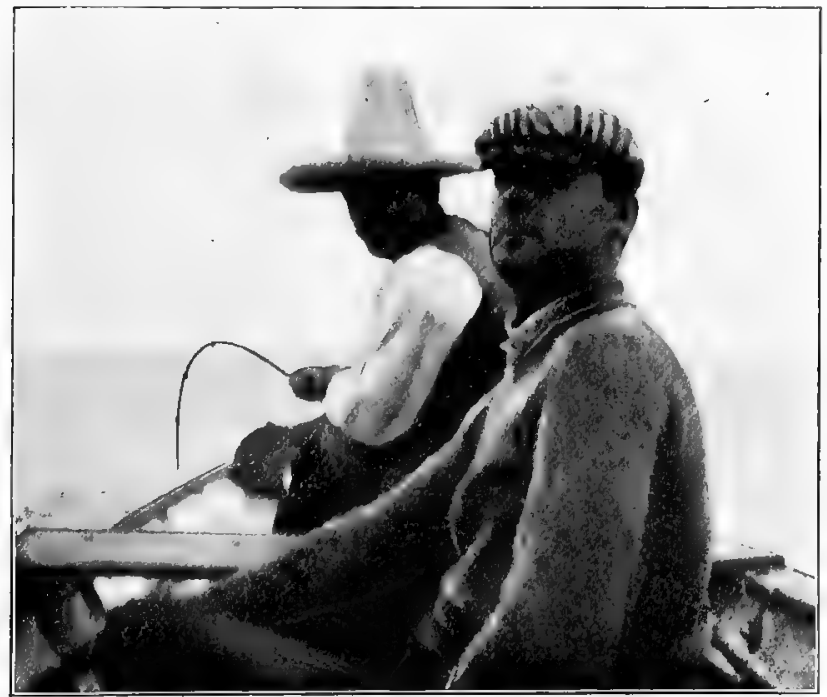

The rod as it looked after the fifth hour of playing a Tuna 


\section{The Leaping Tuna}

on the gunwale pressed it down to the water's edge and cleverly slid the quivering, struggling tuna into the boat, where it pounded the planking with such vigorous blows that the small craft trembled from stem to stern. As its fine proportions were revealed, I realized that we had landed the largest tuna ever taken with a rod. Its actual weight was about one hundred and eightyseven pounds; its scale record weight on shore after bleeding was one hundred and eighty-three pounds; its length was six feet four inches. This catch suggested the Tuna Club, and for two years this fish was the record catch of this organization. I have taken a number of tunas since, and have seen a large number caught, but have never known a fish that so thoroughly exemplified the word "game"; and in justice to this splendid fish which is now in the possession of a Chicago angler, I must confess that a few moments more would have placed me hors de combat.

For staying qualities and hard fighting the tuna in its best condition excels any game fish I have taken, and one secret of success is to fight it continuously without stopping, as when the angler is resting the fish is also recuperating. So fiercely do certain tunas fight that I have 
more than once seen them die suddenly, and a few moments after a desperate rush come up again dead. I have been one of three anglers to battle with a tuna five hours. This fish, though sorely wounded, towed the boat an estimated twenty miles; and had we not, seeing that night was coming on, and that we were out of sight of Avalon in an open boat, hauled it in by hand, I am confident that the fish, which weighed but one hundred and twenty-five pounds, might have towed us across the Santa Catalina channel or for an indefinite distance. Another tuna fought Mr. W. Woods and boatman fifteen hours and then escaped. Yet other fishes are caught in from thirty minutes to an hour. During the season of 1902 Judge Beaman of Denver, Colorado, fought a tuna of unknown size, which towed the twenty-two-foot launch from near Avalon, across the channel, to the vicinity of Point Firmin, an estimated twenty-one miles, in six hours and a half. The fish was lost at the gaffing; the line had chafed off at the swivel. Many tunas, as stated, are caught in a short time; but, as a rule, such fish are in poor condition, or have just spawned, and lack their normal vigor. 


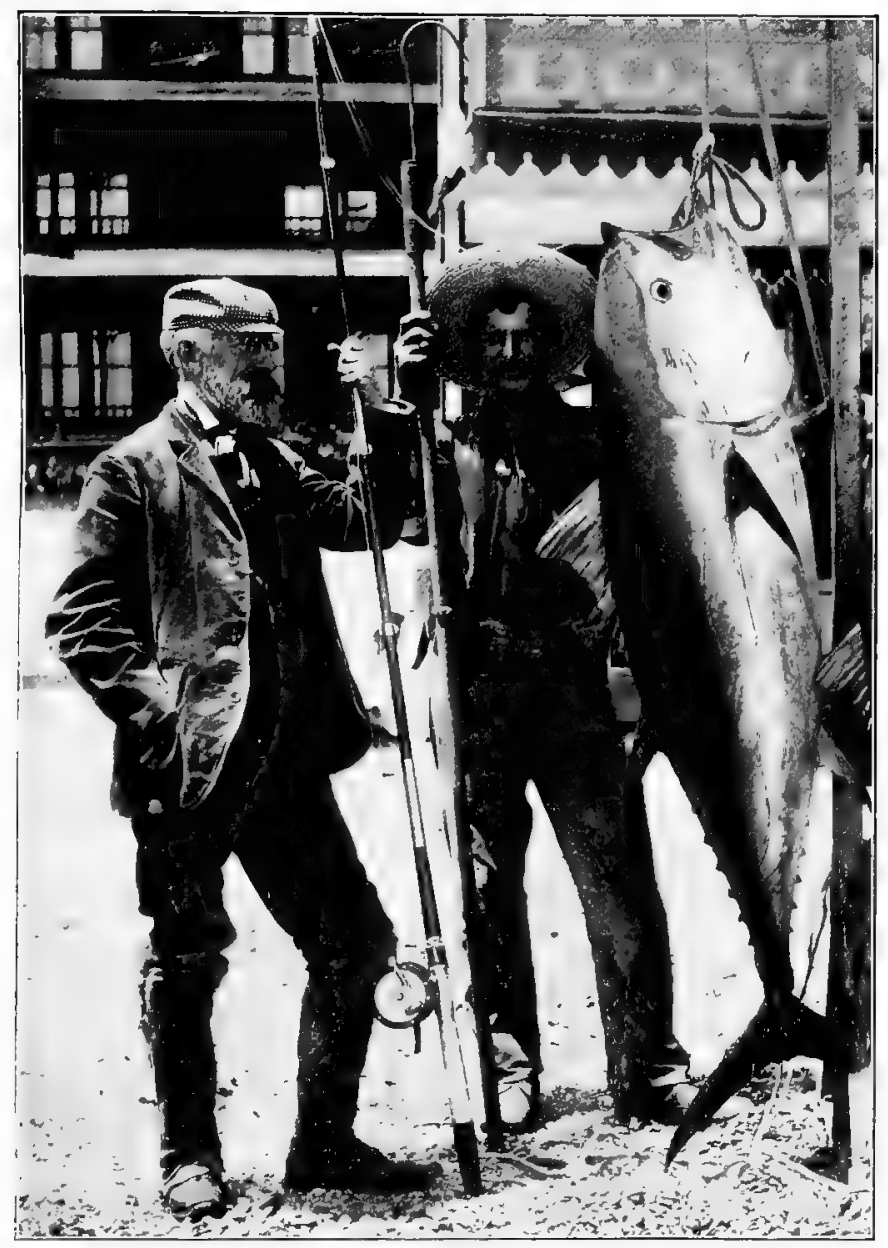

C. F. HOLDER AND HIS RECORD TUNA, 183 POUNDS

Time of catch, 4 hours. Fish towed the boat 10 miles. This was the first large Tuna that was caught 
$-$ 
The largest tuna ever taken with rod and reel was landed by Colonel C. P. Morehous of Pasadena, California, in four hours; it weighed two hundred and fifty-one pounds, and is the record to-day. Mr. H. Gray Griswold of New York succeeded in taking a number of fishes in less time than had been previously accomplished, and demonstrated that they could be caught at any time during the day. The largest number taken in any one season fell to the rod of Mr. E. L. Doran of Avalon, who has done much to make this sport what it is, having been one of the early pioneers in the strenuous pastime.

Among the exciting personal experiences incident to this sport which I recall was being capsized by a tuna nearly a mile offshore. I was trying the experiment of tuna fishing with a light jointed rod, seven and two-thirds feet long, weighing about fifteen ounces, which I used for yellowtail. I hooked my fish, and after a beautiful surface play of forty minutes brought it to gaff. Jim Gardner, the boatman, gaffed it cleverly and landed it, when the fish made a convulsive leap and fell upon the gunwale, capsizing the boat, which sank beneath us, rising bow up, covering the water with gaffs, oars, and other 
wreckage of the angler's art. My companion, Mr. Townsend of Philadelphia, could not swim, and was otherwise embarrassed by a heavy overcoat; and as the boat rolled over and evidently would not hold three, Gardner and I started to swim to the launch, which had been lying off, some distance away, and which was now coming up, while Mr. Townsend rested upon the bottom of the boat, assuring us that he was all right. As I neared the launch I heard the boatman's wife, who was aboard, scream that her husband was drowning, and turning, saw that Gardner had disappeared. Visions of certain big hammerhead sharks flashed through my mind; but as I stopped, endeavoring to look down into the blue depths, up he came, and I discovered that he still held my tuna by the gaff; in fact, he had never relinquished his grasp upon the handle, and was towing the fish, the latter, as it occasionally plunged downward, taking the plucky gaffer out of sight-a performance extraordinary in its nature, which was repeated three times. Each time Gardner, who was a professional swimmer previous to his boating career, dragged the tuna to the surface, and after an exciting and exhausting swim we were 


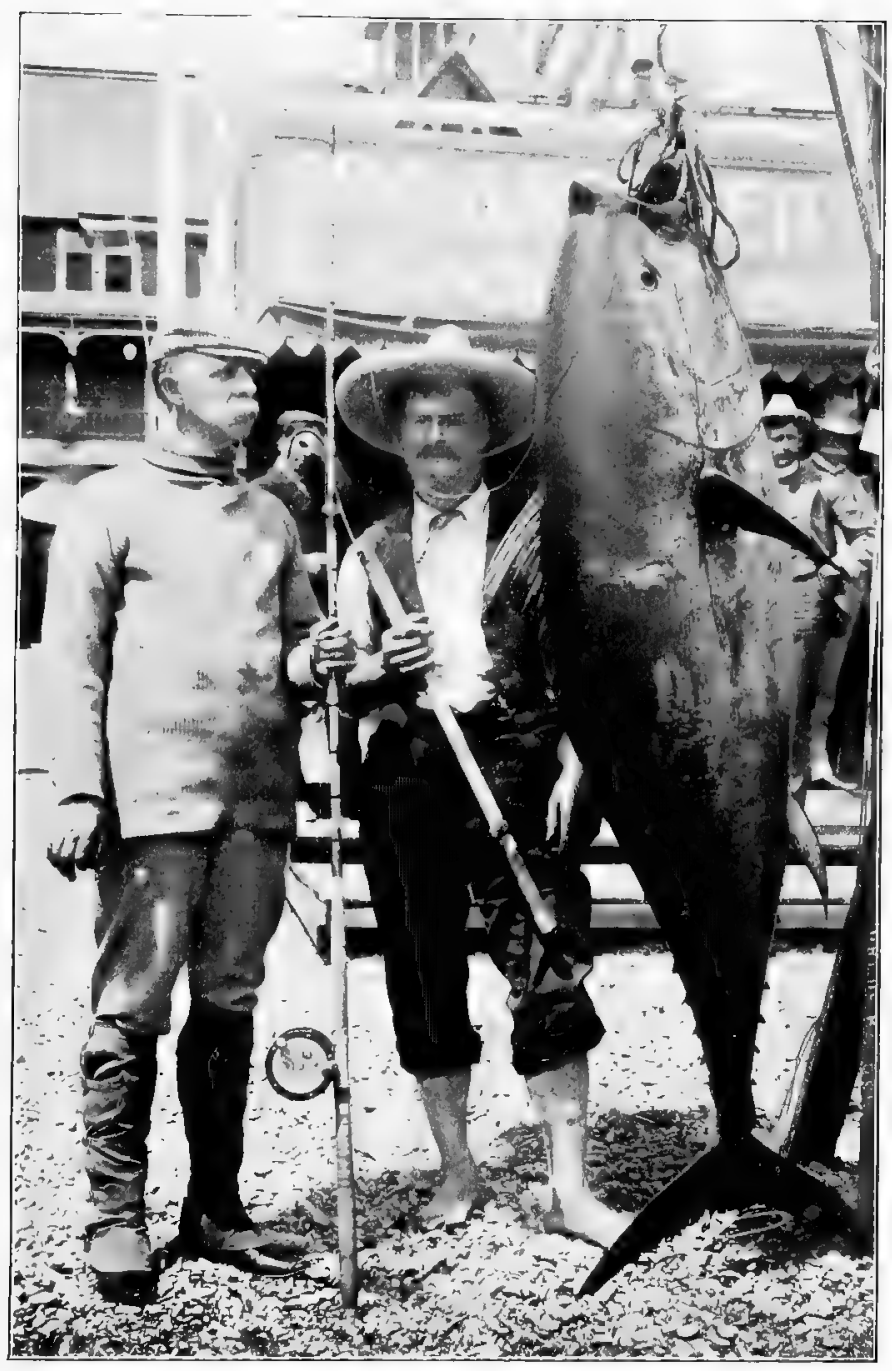

THE WORLD'S RECORD TUNA

Caught by Mr. C. P. Morehous, on rod and reel, 21 strand line; weight, 251 pounds 

picked up, the launch and a fisherman from shore reaching us about the same moment, Gardner securing a rope which his wife tossed him. I was burdened with a heavy corduroy hunting suit and leggings, and found that I could not lift myself aboard, nor could the two men haul me in, so I was lashed to the rail, Gardner throwing his legs about the propeller. In this position we rested a moment, then by a supreme effort I was hauled in, and while the crew held me by the legs I leaned over; and as Gardner lifted up the still struggling fish, I thrust my arm into its mouth and grasped it firmly by the gills; Gardner took a half hitch about its tail with a rope, and the men hauled upon my legs, and with a resounding cheer we dropped the leaping tuna into the cockpit - a laughable climax to a seemingly irrational and impossible fish story. The tuna, which hangs on my study wall, weighed but ninety-five pounds. It is needless to say that Gardner received the prizes of the Tuna Club for the first tuna of the season won in the angling tournament of that year.

The rush of the tunas as they drive in the frightened, demoralized flying-fishes is an exciting and dramatic sight. Droves of the fliers 
are forced out of the water, often to the beach, and the wind, catching their wings, will take them twenty or more feet into the air, where they soar away like a flock of gigantic insects, gleaming in the sunlight like silver. In this pastime the tunas are fearless. They dash into the kelp, high in air, or occasionally out upon the rocks; in the case of a friend one leaped over the stern of his boat. One evening at dusk a school of tunas drove the flying-fishes inshore, and as they passed over and struck our boat, one coming at full speed hit me behind the ear, nearly knocking me out of my seat. Such are some of the incidents, more or less amusing, in this strenuous sport among the Californian islands.

Of all fishes the tuna is the acrobat of the sea, though I doubt if the horizontal leap of thirty feet, accredited to a Texan tarpon, has been equalled by it; but as a high and lofty tumbler, a figure of grace, the tuna equals the tarpon. The leap of the latter is a wild bound into the air, accompanied by a vigorous shaking of its bony jaws, the object being to send the hook flying through the air; and the leap, though sensational, is not particularly graceful. That of the 
tuna is accomplished as a result of the attempts of the fish to seize its prey, the flying-fish, in the air, and is made almost directly upward at the flier, which is a foot or more above the surface. As a rule, the mark is missed, and the living arrow darts upward six, eight, ten feet at rare intervals, then turns with the perfection of grace and plunges headlong into the sea. It is manifestly impossible to measure such a leap, yet on one occasion I thought that I saw nearly fifteen feet attained, though I may have been mistaken, and freely confess to the excitement so often an aid to the imagination. At the time the observation was made I was drifting in the largest school of tunas I had seen. I had noticed the school sweeping up the coast of the island, the channel covered with whitecaps for acres, caused by the rushing, leaping fish, and had rowed out in a light skiff to meet it. Tunas were in the air on all sides; others rushing along the surface, while the flyingfishes soared in all directions in such numbers that I watched them carefully to avoid the winged projectiles. Looking down I could see numbers so terrified that they swam close to the keel to elude the savage tunas. The latter were leaping and plunging about me, and I realized 
that if one fell into the boat it would pass through it as though paper; hence believing discretion the better part of valor, I began to row out of the school, but not before I had attempted a mental calculation of the height of some of the leaps which were being made about me. As I stood upon the seat of the skiff, the rushes of the tunas into the air appeared to the excited spectator, who may in these few moments have seen things which did not exist, to reach a point five or six feet higher than his head.

The possibility of approaching schools of these fish suggests various methods of taking them. That most in vogue is to follow a school and endeavor to head it off, or so encircle it that the bait will cross the leaders; as a rule, two strikes are had if two lines are out, and several times both fishes have been saved. I have succeeded in obtaining a strike when tunas were not biting by heading off the school and casting into it, which is accomplished by reeling the line all in, having the heavy flying-fish as near the tip as possible. When the bait lands in the school with a splash, the tunas evidently consider it an exhausted flying-fish alighting, and forthwith charge it. When other methods have failed, 
they have been induced to bite by running a launch at full speed, with a large, brilliant bait, a white rag, or a large bone jig; this was the method adopted by the professional fishermen years ago, a fast sail-boat being used; but in this way only a hand-line can be employed to advantage. The tuna will readily bite up to eight o'clock at night, or until the phosphorescence becomes too brilliant, and often in the morning at Avalon flying-fishes are found in boats or on the beaches, where they have soared to avoid this rapacious fish.

The breeding habits of the tuna in this region are unknown. The Mediterranean is a breeding ground, and doubtless the Santa Catalina channel is a depository for the spawn, which is laid in the open sea floating on the surface, but young tunas have never been seen here; the smallest observed were about three feet in length, the average adult weighing about one hundred and fifty pounds. In 1902 schools of tunas were seen in February, several fishes being hooked and one caught in March; but this was unusual. It is supposed that they are offshore either in deep water or in milder regions to the south in the larger field of the open sea. In appearance 
the tuna, Thunnus thynnus of science, the king of the mackerels, is trim, attractive, a type of activity, a model of speed, and doubtless the giant of the true fishes, attaining a weight of fifteen hundred pounds or more; a well-equipped foeman for the angler who goes down to the sea after large game.

In the winter the fishes take to warmer water in the open sea; at least this is the supposition, as vessels report them at various times. The tuna was first described by Linnæus, and there is but a single genus and species, the fish being a world-wide wanderer in the warmer seas. In the water the fish appears green, with flashes of yellow; but when landed, the back or upper portion is seen to be a vivid, even iridescent blue, the lower portion silver, in some instances gray. The body is oblong, shaped like the model of some modern yachts, evidently built for speed. The tail has a decided fork, and is a powerful organ, upon each side of which are pronounced keels. The dorsal fin fits into a scabbard, and the side or pectoral fins in old individuals fit into shallow depressions. The scales are seemingly covered with an outer skin. The first dorsal is strong and powerful, and contains from twelve 
to fifteen spines; the second dorsal and anal bear a spikelike fin, following which are from eight to ten finlets, colored a vivid yellow. The teeth are very small, so that the prey - sardines, flyingfishes, or squid - is crushed rather than cut. The flesh of the tuna is excellent, dark and meatlike; but owing to the quantity of other kinds of edible fish it finds little favor among Americans, the catches being taken by Italian and Portuguese fishermen along the Pacific coast. On the Mediterranean it is greatly in demand, but in America its chief value is to anglers, who will go thousands of miles to take it, the sport and that of tarpon fishing well illustrating the importance of a mere pastime as one of the assets of a state. The tarpon brings thousands of dollars into Florida and Texas. The game commissioners of Maine estimate that sportsmen bring five million dollars into their state yearly, while at a recent trial involving the protection of the game fishes of California a commissioner testified that the game of all kinds of the state brought two million dollars to the coast per annum, which shows that sport has become one of the assets of the nation, to be carefully protected and conserved in the interests of the people. 


\section{CHAPTER V}

THE BARRACUDA OF FLORIDA

"Do but fish this stream like an artist and peradventure a good fish may fall to your share." - IzAAK WALTON.

IN the various works on game fishes in this country and Europe, I have never seen the barracuda included among those fishes worthy the angler's attention, and as the result of several years' sport with this long, rakish craft in the Gulf of Mexico, where it was taken with rod, cast-line, and grains, from one to six feet in length, I welcome the opportunity to do it tardy justice. My attention was first attracted to the fish by meeting a Conch on the reef, who answered to the name of "Barracuda." I learned later that he had earned the title as a result of a sanguinary battle with a very large barracuda which had attacked him when swimming, lacerating him so severely that he carried the marks for life.

At first glance the inland angler familiar with 
the muskallunge would possibly mistake the barracuda for this gamy fish of the lakes, as it is long, slender, and pikelike; a silvery arrow, a privateerlike fish, trim, alert, and possessed of remarkable cunning. Its head is long and pointed. The mouth wide, the lower jaw slightly protruding, giving it a bulldog appearance, which in old fishes becomes the support or base of a single large tooth, a companion to others of large size and bladelike shape which make up its armament. The first dorsal fin stands up alone like a leg-ofmutton sail, boomed out by five spines. The second is equally isolated, corresponding to the anal. The tail is forked and a powerful organ for propulsion, and very expressive in the sense of the tail of a cat, vibrating in a singular manner when the fish is about to pounce upon its prey.

There is a single genus, Sphyrana, and twenty species, S. barracuda (Walbaum) of the Gulf of Mexico being the subject of this chapter. It attains the length of between six and seven feet, and the weight of sixty or seventy pounds, this being my personal observation; and I have been informed by "reef combers" that larger specimens have been taken. The range of the fish 
appears to be from Brazil to North Carolina, but the outer Florida reef and the warm waters of the West Indies are its favorite haunts, where the large individuals enter the deep-blue channels of reefs and the smaller fishes frequent the shallow lagoons. The color of the barracuda is influenced more or less by its environment. I have seen them on the gray or nearly white coral sandy bottom of a lagoon when their simulation of the tone was almost perfect. The large specimens are frequently dark green above, or gray; the sides in the young splashed with black, occasionally having a decided black stripe; the sides and under portion of adults silver; some of the fins dark.

About the keys of the Tortugas group the fish is found in great numbers. The spawning occurs in early spring. Very young fishes are rarely seen; others from eight inches to two feet being common in the shallows. Certain barracudas school, this being particularly true of the Californian species, to be referred to; but the great Florida barracuda is a "solitary," an ugly, fierce, and threatening fish, and I can conceive of no "countenance" more savage and vindictive among fishes than this, coming, as I have seen it, out of 


\section{The Barracuda of Florida}

the blue as it followed, wolflike, stealthily in my wake when sculling a dinghy across the channel. All my catches were made from Key West to Loggerhead, within a radius of sixty miles, and most of them in the beautiful blue arterylike channels which encircle Garden, Bush, Sand, Bird, and other keys, where they could always be found. The fish is extremely curious, and so marked are its peculiarities that I was continually comparing it to land animals. In its curiosity it called to mind the antelope, as by certain actions it could easily be attracted within reach of the grains or so that I could cast a live "shad" (Xystama cinereum), mullet, or young garfish before it. This was accomplished in an absurdly simple manner, none less than by tying a bit of white cloth upon a string about four feet long and trolling it behind. As a result, sooner or later, I would see the ugly pointed jaw and black eyes of a barracuda come out of the gloom and approach to within a few feet, moving first to one side, then to the other, shooting ahead slightly, then dropping astern, but never making an effort to attack. The fish was merely curious, and would dash away at the first alarm.

By this it must not be assumed that it was an 
easy fish to take with the rod; quite the reverse in my experience, and I have frequently spent hours in attempts to beguile a barracuda. In fishing for large specimens I found the borders of the channels, where the coral had broken away, forming an opening into a lagoon, a favorite resort, and by sculling the boat along the edge, either with the rag out, or slowly manipulating the oar, a barracuda could almost always be "flushed." Then a hook, baited with live fish, shad ${ }^{1}$ preferred, - was slowly dropped over. In many instances the fish would dart away, but if it so happened that it was hungry, it would poise, its tail vibrating, its hypnotic eyes glaring upon the victim, its muzzle slowly sinking and following as though to charm it; then it would move on, never rushing or darting, but in measured movement, the personification of dignity, until its nose touched the bait, when it would snap it up so rapidly that the eye could not follow the motion. The bait was generally seized by the tail, and the great fish would rise very slowly, holding the struggling shad for a moment,

1 This is not the shad of the North, but a small, very silvery fish known on the reef as "shad," and in Porto Rico as Mojarra (Xystama). 


\section{The Barracuda of Florida}

perhaps two, apparently enjoying its struggles as it beat against its muzzle in desperate efforts to escape; then would come another gulp, and the silvery bait disappeared.

Such was a typical strike, the entire operation being distinctly visible from my position in the stern of the dinghy. When the bait was swallowed or taken entirely into the mouth, I would slowly reel in until all the slack was taken; by that time the barracuda would feel the fine copper-wire leader and would give a convulsive shake of its head, then fairly leap into motion, as it tore the line from the reel, becoming at once a type of activity. Fifty, one hundred or more feet of the line were taken before its rush was stopped, then like an arrow it circled the boat, hissing along the surface as I jumped for the bow and as I hooked it, whirling the light dinghy about and towing it up the channel as would a small shark. Slowly the reel would eat up the line, and finally, seeing the boat, the fish would dash down with an impetuous rush, making the click sing again, rising to circle the boat once more and again slowly coming in after a splendid display of strength and power. Such a fish would often defy a single man, trying to gaff his 
own fish, for an hour and then drench him, as it thrashed the water in a final struggle, snapping viciously and seizing the woodwork in its ugly teeth in rage or agony.

Another method of taking the large barracuda was to have a boatman row me along the channels, and troll, using mullet or sardine bait; but the most satisfactory method was to first attract their attention, then take them when all their movements could be observed. The capture of a six-foot barracuda is by no means an easy matter if the rod is used, and even with a cast-line the fish makes a long and vigorous fight, never giving up. The tackle employed in this sport was similar to that used in white sea-bass fishing; but the line should be light, a number twelve cuttyhunk; that is, if the angler wishes to fairly match his skill with that of the fish. The leader should be a long, slender, copper wire; the hook small (I preferred a 2/o O'Shaughnessy, though many use a larger hook); the bait proportioned to the size of the fish. For the largest barracuda a mullet four inches long is sufficient. It is a purely carnivorous fish, requiring bait with shining sides, like mullet, sardines, gar, young of their own kind, scorning, at least in my experi- 
THE BARRACUDA 



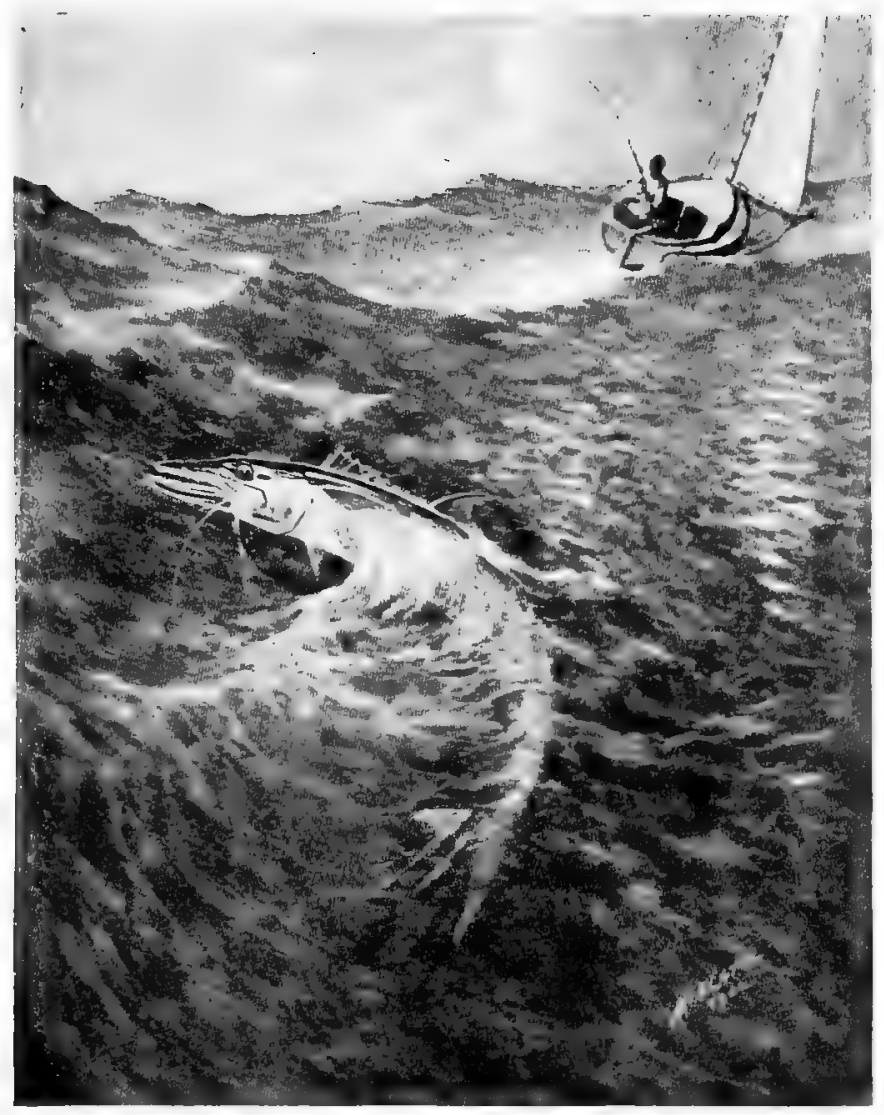



ence, crayfish, shrimp, worms, conch, and other baits in vogue on the reef for other fishes.

This barracuda affords excellent sport in all stages of its growth, the young, from one to two feet long, being very gamy and remarkably cunning. A favorite place for them was off the shores of a key from which I could distinctly see every object thirty or forty feet from shore. The fishes could be seen lying motionless a few inches from the bottom, so simulating it in color and tint, that they often appeared the very ghost of fishes or shadows, the latter, under the noonday sun, being more conspicuous than the fish. In this case I used live or dead bait and cast far beyond them, then manipulating the line with the greatest caution so that the bait could be dragged within their line of vision. The moment a barracuda noticed the dazzling silver of its sides, it would move slowly toward it. For this sport my rod was a nine or ten ounce bass rod slightly shortened, so that it would not be too pliable, as I found that a twenty-four-inch barracuda is the superior of a much larger lake trout. On would move the barracuda, as though propelled by some mysterious force, until its pointed muzzle penetrated the very sand beneath the bait, which, if 
dead, I now gently moved to make it simulate life. The fish would gaze at it for a few seconds, then back off to move slowly forward again, tipping it over, as though wondering what was the matter; and if there was anything suspicious about it, at this stage my fishing often ended. They confessed to an overweening curiosity, nosed the bait and moved it, when I succeeded in making it struggle, but often would not take it. Again my patience would be rewarded by the lightninglike snap, and the fish would rise proudly to later take me knee-deep into the water to save the slender rod or line.

The bait of baits is a live, vigorous sardine or the "shad" referred to, and frequently I had negro boys accompany me alongshore with a fine cast-net, or a long piece of mosquito bar, with which small fry could be taken and used fresh from the water when a good-sized barracuda was located. Such lures would rarely, if ever, be refused, though I have known certain fishes to scorn every attempt to attract their attention. In fishing in deep water, peering down into the channel to watch the graceful jellyfishes or the long purple anchor chains of the physalia as it moved along, I have seen the muzzle of a huge 
barracuda come into view, the arrowlike form moving gracefully, imperceptibly by, like some grotesque torpedo with staring black eyes. Such fishes are dreaded by old "reefers," and many stories are related, especially of the Bahama barracuda, which suggest that as regards fierceness, the fish should be classed with the shark. Yet it was my custom with others to swim across and through a deep channel daily where large barracudas were abundant, and so-called man-eaters more so; but we were never disturbed, and the only reliable instance of a barracuda attacking a swimmer, that came under my notice, was the one referred to. Regarding the vicious reputation of the great fish, Jordan and Evermann say that it is "sometimes dangerous to bathers, being fierce as a shark."

The barracuda is an edible fish. Outside what might be termed "pan-fishes," as yellowtails, grunts, and a few others which are excellent, I would give it the first place; yet on the Cuban coast and in some of the West India Islands the fish is supposed to be poisonous at times. This was certainly not true seventy miles from Cuba, where I caught and ate the fish every month in the year. At Bahama and along the reefs of the 


\section{Big Game Fisbes}

West India Islands and at our province of Porto Rico the barracuda attains, according to common report, a very large size, eight feet being mentioned as its maximum growth by the United States Fish Commission.

Of the habits of the great barracuda in its solitudes, little is known. The fish so interested me by its singular personality that I watched it whenever opportunity offered, and it was always the uncompromising foe to small fry, lurking near schools of sardines or mullets, creeping upon them with the slightest display of motion on the part of its fins, conveying the impression of a Machiavellian cunning, of ferocity coupled with "ways that are dark," its entire make-up being suggestive of the tiger which creeps upon its victim and delights in playing with it. 


\section{CHAPTER VI}

\section{THE CALIFORNIA BARRACUDA}

"Angling is somewhat like poetry, men are to be born so."

- IZAAK WaLTON.

IN May or June the picturesque, lateen-rigged boats of the Venetian and Portuguese fishermen of San Pedro, California, go out in search of the barracuda which is due at this time, coming in from the outer and deeper sea, or from "down alongshore," that mysterious locality where many fishes winter. They have two or more handlines boomed out to starboard and port, and before the stiff trade, fly over the Santa Catalina channel trolling for the California barracuda, probably the most valuable food-fish on this particular piscatorial horizon. The fisherman has a cord or sheet fastened to his boomed-out lines, and when a strike comes, or the bone jig is taken, he hauls the line aboard by this contrivance and brings in the fish hand over hand, without even luffing for courtesy. 
The discerning angler may read between the lines the truth. This barracuda is the antipodes of its Floridian namesake and kinsman, and its appearance in these pages is due to one fish, one of many taken, which made a gallant fight, and the fact that barracuda fishing is one of the sports and pastimes all along the coast of Southern California from San Diego to Santa Barbara and beyond. It comes in large schools, in this also being totally unlike its Gulf of Mexico cousin, and often tints the very waters a delicate yellow with its vast numbers. In looking down from the boat thousands of pointed muzzles and black eyes are seen, the fishes often lying so thick that they appear to be a solid mass; so closely packed that I have hooked a fish accidentally by jerking it up among them. At such times the barracuda will not bite. You may dangle the most luscious morsel at its very nose, but it will scornfully pass on; at others, especially in water slightly rough, the schools appear to break up, yet retain a certain continuity, and then they bite; not occasionally, but all the time, and seriously interfere with yellowtail fishing. This, with apologies to the devotees of the barracuda. 
Owing to its sharp muzzle, it is somewhat difficult to hook the fish, and it has an aggravating method of nibbling at the bait, or nosing it. The novice, thinking this a genuine strike, gives M. Barracuda the "butt" and misses again and again, reeling in to find that this inglorious sampler has bitten off a piece of the tail of the sardine as a souvenir; hence, the fish has become known as a promoter of invective on the part of the boatmen who are baiters as well. To obviate all this, the angler should not endeavor to hook at the first nibble but, if it is a decided strike, should slack off the line, overreeling for a few feet, thus affording the fish an opportunity to swallow the bait. If hooked some individuals surrender at once, refuse on any terms to be a party to sport of this kind. One fish, which I hooked, deliberately swam toward me, saving me the trouble of reeling, and I doubt not would have jumped into the boat, as they have been known to do, had not the dismayed boatman, with an ill-concealed "Well, I'll be dogged!" jerked it aboard with the gaff.

To offer this as a type of the California barracuda would possibly be a libel upon the species argentea, as nearly all fight as well as the average 
pickerel of seven or eight pounds. The fish referred to at the beginning of the chapter was taken on an eight-ounce split bamboo trout rod, with a number nine cuttyhunk line, and gave excellent sport; making fine rushes, swerving from side to side, and finally at the surface, lashing the water into foam, acting in so gamy a manner that the boatman expressed the opinion that it was insane. A trout rod is too light for the barracuda, which runs up to fifteen pounds and is often four feet in length. I would suggest a light greenheart, or a split bamboo, such as would be used for pickerel in Eastern waters. The barracudas are taken almost entirely by trolling, although the professional fishermen "chum" them up at times, and when they "get them on the run," haul them in as fast as the lines touch the water, using a white rag as bait, the barracudas, like mackerel, losing their heads and snapping at anything. The most satisfactory sport I have had with these fishes was to cast into a school where they were biting, and by reeling "quickly take them; in this way they will often follow the bait up to the boat, displaying no fear.

The California barracuda is Sphyrana argentea (Girard) and like its Gulf of Mexico relative 
belongs to the family Sphyranida. It is a long and very slender fish, the lower jaw projecting, the muzzle sharp and pointed, the eyes black and conspicuous. Its colors are brown or green above, the belly white. When taken from the water the back, like that of the yellowtail, often takes on a bluish, almost iridescent, hue. The fins are tinted a light yellow, so that when the fish is seen deep in the water, it is sometimes mistaken for the yellowtail. Along the mainland the barracuda rarely ventures inshore, most of the catches from San Diego to Santa Cruz being made from one to five or more miles from the surf; but at the islands, - San Clemente, Santa Catalina, Anacapa, Santa Rosa, Santa Cruz, and San Miguel,- - where deep water sweeps the very rocks, the barracuda is caught not one hundred feet from shore, great schools moving up and down the fringes of kelp - the fishes' highway - in search of anchovies, sardines, and squid, the food of its choice. There are several "runs" of this fish, which mean that large schools move in, or up the coast, at intervals. That they follow the general contour of the mainland is certain, as in the spring the barracuda is first reported from Coronado; then the fishermen catch them from 
boats off Redondo and San Pedro, and it will be often two weeks after this that it appears at Santa Catalina and other islands, where it is taken with more or less regularity up to August and sometimes later; in September it disappears.

The barracuda spawns in San Diego Bay and at San Pedro, and I have seen young barracudas about two inches in length in Avalon Bay and hence assume that this harbor is also a spawning ground. The young were in the kelp in schools of perhaps two or three hundred, and were remarkable for their shyness, it being almost impossible to catch them, and for the rapidity with which they moved. The entire school, as though prompted by a single thought, would dash away several feet and take up a position, all headed in one direction; and when alarmed, make a second move, always preserving a certain continuity, most interesting to the observer, peering down through the olive-green fronds of the kelp. I have never observed at any of the islands a barracuda between the very small specimens and the adult, but intelligent fishermen have informed me that barracudas of all sizes are found in the fine bay of San Diego. 


\section{CHAPTER VII}

THE BLACK SEA-BASS

\section{"Hugest of all fishes in the sea}

For they were formed by heaven's great king Before all other earthly thing."

- The Voyage of St. Brandon (Mediæval).

Around many portions of the Californian coast, éspecially its islands, there is a submarine forest of great density. The trees are represented by the so-called kelp, the Macrocystis, which attains a length of several hundred feet, rising upward in broad deep-green leaves of gigantic size, which swing in the current undulating like living things, forming a maze or forest, which, while easily seen, is a closed region even to the diver owing to the intricate convolutions of the plants. Looking down into this mimic forest when the sun is overhead, the scene, especially when observed through a water-glass, or a glass-bottom boat, is fascinating. Arches, loops, parterres, festoons, colonnades, every pos- 
sible conception which the imagination might devise, is seen, glorified by the sunlight and bathed in marvellous tints of green, while through every interstice the deep-blue water forms a matchless mosaic. At low tide the long fluted leaves lie like snakes upon the surface, the wind often lifting them, but at the flood they are submerged and swing in the current at an angle of thirty-five or forty degrees; now straightening up or turning, according to the whim or fancy of the mysterious currents which are found about these islands bathed by the Kuroshiwo, the great Black Current of Japan.

This submarine forest is the home of the king of the bass, Stereolepis gigas (Ayres), the gigantic black sea-bass, possibly the largest of all the serranoids. In appearance it bears a marked resemblance to the small black bass. Imagine a small-mouth black bass seven feet in length, weighing six or seven hundred pounds, and some idea of this monster, which is a common fish in the region described, may be conceived. It has been my good fortune to see the fish in its native haunts. Lying prone on the deck of a small boat, with my face within a foot of the water, I was watching my bait forty feet down among 


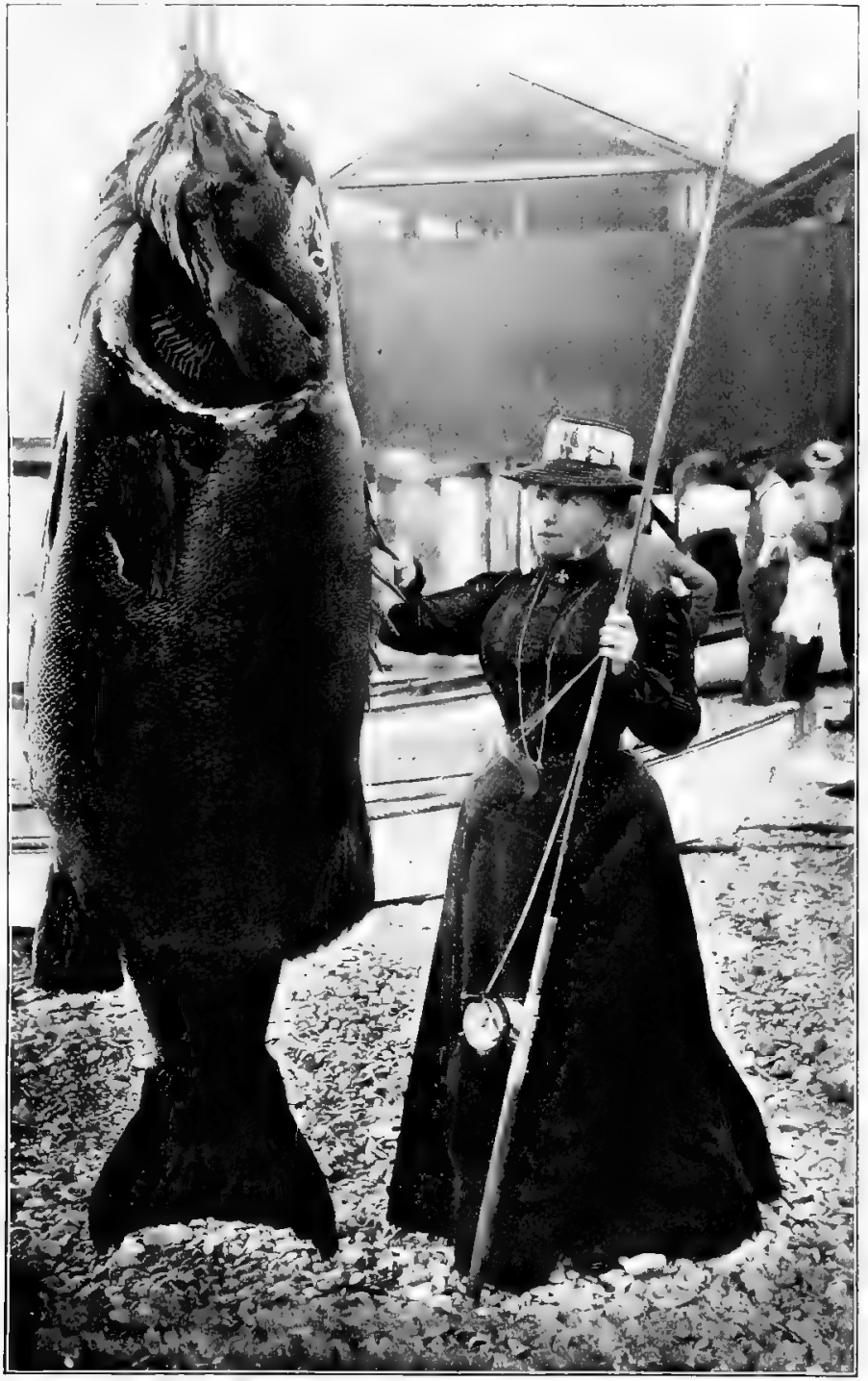

THE LARGEST FISH EVER TAKEN WITH A ROD BY A WOMAN 

the stems of the kelp, the water being so clear that every object could be seen. As I looked, into the range of vision, through a curtain of kelp which it seemed to push aside like a portière, came a mighty fish which I recognized as a black sea-bass. It was at least six feet in length, weighing possibly three hundred pounds, and simulated the color of the weed. At its approach the small fry and numerous sheepshead disappeared before the king. Its movements were slow and dignified, as became its size, and guided either by scent or sight it swam toward my small sardine bait prepared for yellowtail, gazed at it warily and passed on to return and view it from another position. A score of times this gigantic fish, which I had previously imagined a glutton that rushed at food and bolted it, played about the bait with tactful movements, the personification of caution and deliberation; then, as though satisfied, it poised directly over it, depressed its muzzle until it stood upon its head, tail upward, then took the bait and slowly moved off. When it felt the wire leader a whirlwind seemed to have struck the kelp forest, leaves and stems being tossed hither and yon in a vortex as the tail of the mighty bass swept 
through it beyond my range of vision. I had but two hundred feet of fifteen-thread line on my yellowtail reel, hence the end soon came. The reel uttered a vigorous protest, and the line parted. But I was well paid; I had seen a big sea-bass standing upon its head in the heart of this maze of kelp.

This fish makes its home in these dense lamarian forests and is found in-abundance from the Coronados and Cortez Bank, and doubtless farther south, to the latitude of San Francisco, lurking in the kelp beds around rocky points near shore from April to December. In July and August it spawns, and fishes caught at this time are filled with enormous masses of eggs which are deposited beneath the kelp in shoal water from twenty to thirty feet deep, near shore. At this time the fishes are very ravenous and bite eagerly, but on or about November I 5 they become scarcer, and are rarely caught, though they do not entirely disappear. There is reason to believe that they run in schools at this season, and go offshore to deeper water. They attain an enormous size. I have caught many specimens from one hundred and fifty up to three hundred and fortyseven pounds, and specimens weighing four and 
five hundred pounds have been taken, while the Santa Barbara Islands claim a bass which tipped the scales at eight hundred pounds, and fishes of this size have been taken in the Gulf of California. At Santa Catalina and San Diego the average bass weighs two hundred and fifty pounds, and small individuals are rarely seen. The smallest fish observed by me at the former place weighed thirty pounds, and fishes under one hundred pounds' weight are very rare. Where the very young go is a mystery, as they are never caught; possibly they frequent the deeper waters offshore. In 1870 there was a black sea-bass fishery at Pebbly Beach, Santa Catalina, and the Portuguese from San Pedro caught hundreds of these bass by employing the heaviest of hand-lines, small ropes, with which several men could soon master the largest fish. The fish were killed on the spot and their heads thrown into the water, resulting, according to local tradition, in so alarming the fish that they deserted the locality and have never been caught there since. The meat was dried and sold as boneless cod, but was found to be too tough and dry for this purpose.

Fishing for the giant as a sport has long been in vogue at the islands off Los Angeles County. 


\section{Big Game Fisbes}

Previous to 1895 the fishes were caught entirely with the hand-line, but about that time General Charles Viele succeeded in taking a large fish with rod and reel, and since then this has been the method employed - anglers landing fishes ranging from three hundred to four hundred pounds with ordinary tuna tackle. While the rod is to be commended as the most sportsmanlike, the fish gives the angler more exercise with the hand-line, and will easily jerk the absent-minded fisherman overboard. I took my first bass in the latter manner in 1886. My boatman provided a line which in the East would have been sacred to sharks; the hook was a small edition of a shark hook, while a chain served as a leader. The bait was a five-pound whitefish, hooked through the back so that it would swim. A half-pound sinker was attached, and this crude contrivance, an insult to the bass tribe in general, was lowered within six feet of the bottom and the waiting begun. "How poor are they that have no patience" is well exemplified in this pastime, as without patience no one ever landed a black sea-bass. Catches of four or five a day have been made, but the average is one, and often the wait is long and wearisome to the angler who has no other re- 
sources. On the day in question the strike came in half an hour. Some idea of the strength of this fish can be conveyed by giving the details of a catch made by me in I894. My companion had never seen the fish caught, and insisted upon taking the place of boatman for the exercise. In a weak moment I consented. The skiff, as I ascertained later, weighed one hundred and twenty-five pounds, our combined weight was three hundred and fifty pounds. After an hour's fishing we had by great good luck caught enough sheepshead, so we threw over the large hand-line for black seabass. The anchor was hauled up and the boat made fast to the kelp ready to cast off at a moment's notice, and within fifty feet of the beach we began to fish. It was not long before the line began to move over the rail, and I took it in hand while my companion cast off the big kelp leaf which held us. Out ran the line, slowly and deliberately, the "bite" of this colossus being a surprise to the novice. I allowed twenty feet to pass over, then assuming that the bait was well in the mouth of the fish, theoretically gave it the butt. The answer came on the instant in so terrific a jerk that I was thrown upon my knees and my arms hauled almost elbow deep in the water 
before I could release the line, while the impact had jerked the light boat around as though on a pivot, and thrown my companion down. In the meantime the line was rushing over the side. As I seized it, the fish surged downward, taking the stern of the light craft almost under water, dragging it rapidly and irresistibly along. We were carried two hundred yards out to sea before I succeeded in stopping the fish, my companion having shipped the oars, pulling violently against it. By rapid manipulation I brought the fish to within twenty feet of the surface and caught a glimpse of its huge form, the dark brown back and the flash of silvery belly; then seeing the boat it made a rush that nearly carried the skiff with it and took all the line I had gained, in the direction of the inner kelp bed just beyond where the sea was breaking heavily on a point of rocks. Once in the kelp I knew that the bass would escape, so redoubled my efforts while my companion lay flat, balancing the boat, as the fish seemed determined to carry it under water, so fierce were its rushes. The bass would plunge downward, then deliver a series of blows, armwrenching in their power and probably given by striking the head from side to side by convulsive 
lateral movements of the entire body; then, when hauled up with the greatest possible effort, it would circle the boat, endangering the craft, stop and lash the water and impress us with its immensity.

For nearly an hour this fish fought me, as the boat was so small that but one could play it; and had my companion not remained in the bow the bass would have sunk the frail craft. It was finally brought to the surface, and holding it with one hand I gaffed it with the other, when with a tremendous rush it was away, wrenching the gaff from my hand. Four or five times it repeated this, and when I finally held it by the gaff I could not kill it, so fierce were its lunges. A heavy swell was now coming in, and there was a rough point to turn at Church Rock. It was manifestly impossible to take the fish into the boat, so I held it while my companion rowed, its lunges almost swamping us in the seaway as we rounded the point. Three miles from here we met some fishermen, and by the aid of five men the big bass was hauled in, almost filling the boat and bringing it down to within a few inches of the water's edge. But the two boats convoyed us into port, where the big fish, which weighed between three hundred and four hundred pounds, 
was hauled upon the beach. It was not believed possible to land so heavy a fish with a rod, but I was fortunate in seeing the first one taken in this way. General Charles Viele and myself were fishing with rods from an anchored launch two hundred feet from the shore at the "fence," Santa Catalina. The General had a strike almost immediately, and springing into a small boat with the engineer as an oarsman was rapidly towed away. In about two hours he had mastered the fish and had it on the deck. When he was playing it I had hooked four or five, losing my lines and breaking two tips, it being impossible to stop the rushes with light tackle (twenty-one-thread line) from an anchored boat. Finally, my rod being entirely depleted, I tried a hand-line, and in less than an hour landed two bass. One weighed one hundred and fifty-eight pounds and another two hundred and seventy-eight pounds, the latter with the aid of General Viele. We returned to port with three bass, one weighing one hundred and fifty-eight, a second two hundred and seventyeight, and the third two hundred and fifty-eight pounds, before lunch. This was the initial rod catch of this fish, and since then scores have been landed with rod and reel, the record catch 
being held by Harrison T. Kendall of Pasadena, with a fish weighing four hundred and nineteen pounds. The second largest was taken by $\mathrm{Mr}$. F. S. Schenck of Brooklyn, New York, and weighed three hundred and eighty-four pounds.

The tackle in vogue for this athletic and vigorous sport is similar to that required for tuna fishing. The same sized hook is used, a twenty-one-thread line, and a long eight or nine foot wire leader to prevent chafing, while above the leader or snell the line should be either doubled or provided with a fifteen-foot upper leader of strong cod line. This is to give the boatman purchase when the fish has been brought to gaff, as it almost invariably lashes the water, hurling spray over boat and fishermen.

As to the standing of the black sea-bass as a game fish there is much difference of opinion. Some claim that it is superior to the tuna, but in this I do not agree. I have taken possibly twenty bass of various sizes in hard hand-tohand contests, and am fully impressed with their power; but in agility they do not compare with the tuna or tarpon. I should class the black seabass with the Florida jewfish and large black grouper, though it is much more active than the 
former and more attractive, having the general shape of a bass in the water. When hung up and distorted, no idea can be had of its shape. As to its qualities as a food-fish there is the same difference of opinion; the large fishes are dry and coarse, but specimens of one hundred or so pounds, if properly baked, are very good. If a fish is common, it is often despised, and if hideous in appearance, repudiated; this is exemplified in eels and sculpins, both fit for the gods if skilfully prepared; but the latter is scorned in the Atlantic, while in California it is esteemed very highly.

The method of taking the black sea-bass in California waters is to fish from an eighteen-foot launch or a boat light enough for the fish to tow readily, but still large enough to hold from one to three bass of two hundred pounds each, if the angler is so fortunate. The launch is anchored either at the inner or outer kelp beds, the anchor line buoyed so that it can be tossed over the moment the strike comes, as the fish invariably tows the boat until killed. On these grounds albacore bait is the best, three or four pounds being used, while live whitefish or half a barracuda are not to be slighted. This great bass 


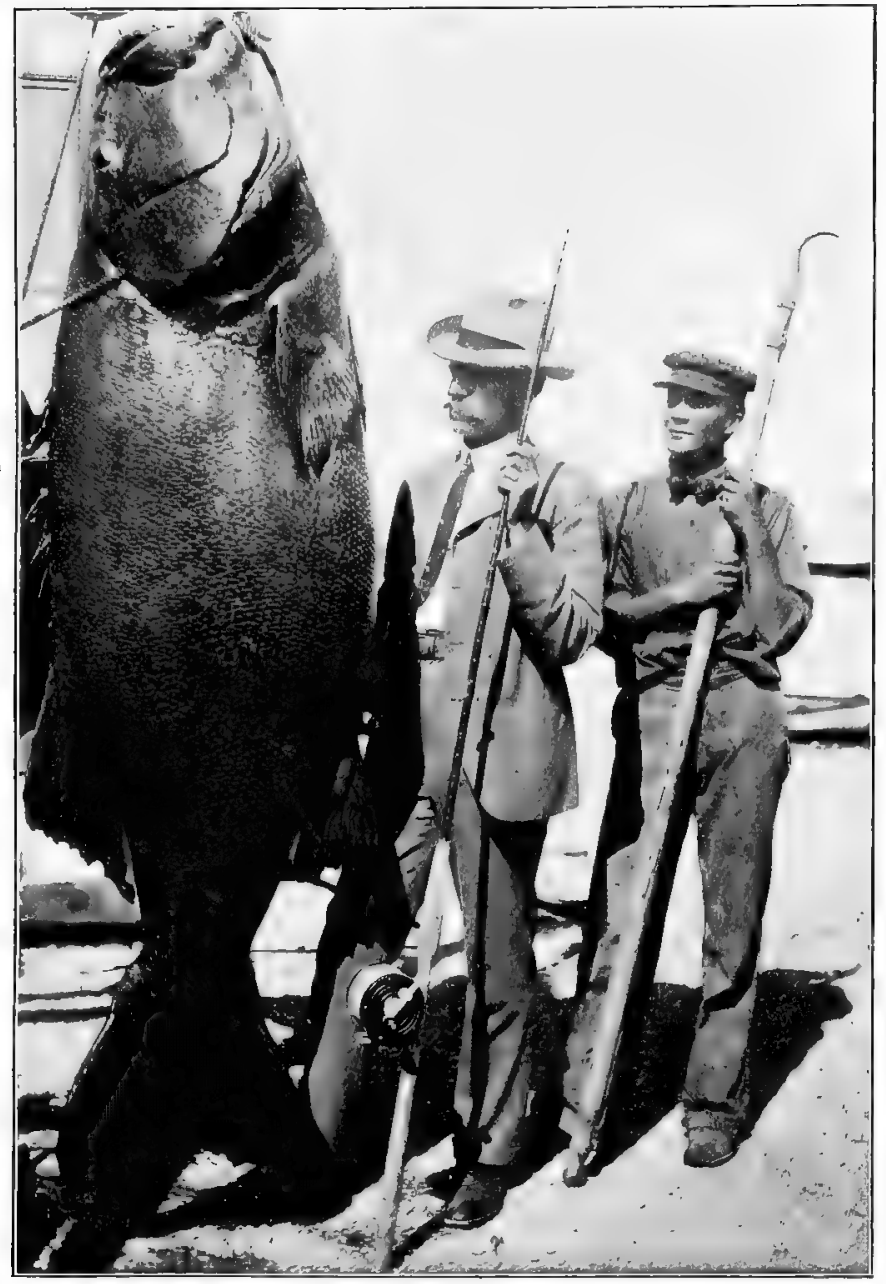

RECORD BLACK SEA-BASS, 419 POUNDS

Taken at Santa Catalina, Cal., by Harrison T. Kendall, Pasadena, Cal. 

has been caught when trolling for yellowtail with sardine bait, but this is exceptional, though I believe by trolling with a pipe sinker that would keep the large whitefish bait twenty feet under water, the bass could be taken in this most attractive way. There seems to be no choice in the position of the bait. If half of a barracuda is employed, or four or five pounds of albacore, a veritable shark bait, it is taken either on the bottom or a few feet above it. That the great fish has many of the attributes of the typical bass is shown by its habit of chasing whitefish to the surface; many times when reeling in a gamy whitefish, I have seen the gigantic form of a black sea-bass dash upward, snapping at it, causing the water to boil like a miniature maelstrom. Often the bass seizes the fish and makes away with it, line and all. The bass does not make the long rushes of the tuna. Four hundred feet of line is sufficient. A novice should never attempt the sport unaided. It is a sport for two men in a staunch boat, as large fish may tow a frail boat to sea or capsize it; yet expert anglers who delight in strenuous conflicts with these huge fishes have played them, brought them to gaff, and hauled them into the boat single-handed and alone. 


\section{CHAPTER VIII}

THE HOGFISH

"And there were crystal pools, peopled with fish, Argent and gold; and some of Tyrian skin, Some crimson-barred."

- Thomas Hood.

THE angler is a true lover of nature; were he not the gentle art would flag and die, as in his experience there come dark days when the game for some strange and unreasonable cause will not rise, or sink to the lure. By such periods you shall know the true rodsman, as when the fish refuse to bite he finds solace in a thousand and one objects : the soft sighing of the leaves along some favorite stream; the gurgle of the water as it flows from pool to pool; the call of the locust, which "stabs the still air with its shrill alarm" are all understood. If a sea-angler he can "call spirits from the vasty deep"; the deep blue of the ocean, its many moods, the shadow of clouds upon its surface, the delicate glasslike shapes that drift across his line; the sounds of 
the sea which come from far away, deep in the heart of some roller from the vast unknown, at first low murmurs, then the clash of cymbals as the silvery crest topples over, bursting into thundering crash all down the line, spreading out upon the sands, where the pebbles are castanettes, or leaping high upon the face of some rocky cliff with ponderous roar, - all these the true angler loves and understands, so never draws a blank in a day's fishing. To the world he goes a-fishing, yet the actual catch is far from being the sum total of his pleasure; he never fails to land his game, if not fish, some new delight in the appreciation of life and nature.

The haunts of the hogfish are among the most æsthetic of all fishes, and if the game is not found when sought the angler may pass the day taking the many-hued courtiers which make up the train and retinue of this radiant creature. My fishing-ground was a long submerged coral reef, which began with Bush Key of the Tortugas reef and extended southward, a barrier to the sandy lagoon to the west. The reef was made up of dead coral heads, which were bare at extreme low tide, but at the flood the sea rolled over it, pounding so furiously in storms that the roar could be 
heard far away. Out from the reef the water deepened so quickly that fifty feet to the east it was twenty feet deep and the bottom rapidly fell away, merging into the deep water of the Gulf Stream. In the shallows were many large heads of coral, some like huge vases, hollowed out, the homes of angel and other highly colored fishes, while the floor of the reef was covered with a forest of waving plumes of gorgonias, massive seatlike sponges and other forms. There were rich yellow reticulated sea-fans, three feet in height, with beautiful yellow shells clinging to them. Others were of the richest lavender hue, while here and there were plume-shaped forms in brown plush tints, long branchlike shapes in black, lavender, and yellow. Beneath these was a carpet of low-growing algæ, and patches of fan coral in large palmate branches of a rich olive hue, with round heads and clumps of branch coral everywhere, forming a garden in the sea of marvellous beauty.

Not far away a fine large ship had gone down, and part of the hull lay in this garden spot in deep water, while the rest, tossed by the hurricane like chaff over the sharp teeth of the reef, lay in the smooth shallow water of the lagoon. Peering 


\section{The Hogfisb}

down into what had been the hold, now filled with growing coral:

"Methought I saw a thousand fearful wracks;

A thousand men that fishes gnawed upon;

Wedges of gold, great anchors, heaps of pearl,

Inestimable stones, unvalued jewels.

All scattered in the bottom of the sea."

This ocean garden, which flashed every tint or color, was the home of the hogfish, one of the gamiest of the tropical fishes and, with its long plumelike fins and its coat of red, one of the most beautiful. Ordinarily, fishing was had by pushing the dinghy through a narrow channel, known as the "five foot," the only retreat through the great reef in case of sudden squall, and anchoring in three or four fathoms; but I often preferred to haul my boat upon the reef on the lagoon side at the ebb tide, wade out waist-deep, and climb upon a coral head, or a heap of dead heads, which had been piled up for the purpose, and fish standing in the water without the boat to alarm the game. On the average summer day the sea was glasslike, the heat intense, the water so clear that every object upon the bottom could be seen. Every head, fan, and bunch of coral was the home of some gaudy or beautiful fish. The radi- 
ant yellowtail, Ocyurus chrysurus, was most common and one of the gamiest. The angel-fishes, especially the black and white variety, would astonish one by their strength, while the great parrot-fishes in gorgeous tints should be included in any account of game fishes, affording good sport with light tackle.

Among these gorgeous creatures, which seemed colored to accord with their environment, the hogfish reigned supreme, its striking shape and brilliant color rendering it a conspicuous object as it poised beneath a lavender sea-fan, as though for effect, or slowly swam about followed by a train of curious and brilliant yellowtails. The hogfish ranges in weight from six to twenty-five and even thirty pounds, though the large specimens are rarely caught, individuals weighing twenty pounds being considered large. But this ocean park in summer was the home for fishes of extreme size, and the sport they afforded compensated for the pitiless heat that ashore made butter a liquid and life correspondingly miserable.

The best fishing was in the morning, and by poling over the lagoon in shallow water, just at sunrise, quantities of crayfish could be caught feeding, and grained, - the bait of baits for hogfish, 


\section{The Hogfisb}

the tail making three large baits, which were fastened upon the hook with soft copper wire or thread - a measure to outwit the small fry. I used a rod about eight and a half feet long, weighing sixteen ounces, a reel which held three or four hundred feet of a number twelve line. The leader was three feet of very light but strong copper wire, with no sinker; the tackle was exactly what I used for the six and eight pound yellowtails, the only difference being that for the latter often a trout rod was employed. A larger hook was necessary for the hogfish, its enormous mouth rendering a very small hook inoperative. With a big net to hold the bait and to bag the game, and sometimes a pair of grains, the coral head was mounted and a cast thirty or forty feet made out into deeper water, where the bait could be seen white against the blue, sinking slowly into the forest of plumes and fans. Up rose a cloud of fishes to meet it. Now "breathe soft ye winds! ye waves, in silence sleep," as attracted by the swarm of small fry that tosses the bait hither and yon, filling the water with flecks of white, comes a vision in red, a harlequin, or Mephistopheles of the sea, with flaunting plumes. It shoots ahead with a peculiar arrowlike flight, 
the yellowtails parting on either side, and presto ! the large bait disappears in the maw of the hungry hogfish. As it turns and attempts to descend the slender copper leader sags into the corner of its mouth, the point of the hook pierces its soft jaw, a streak of red and fading plumes and the fight is on.

The great height of the hogfish and the powerful tail enable the fish to make a fight which, when unseen, as is almost invariably the case, impresses the angler with the belief that a much larger fish is hooked. And so with my fish. At long range I estimated it at twenty pounds, as it nearly jerked me from my uncertain foothold, but no forty-pound kingfish or barracuda ever made a braver rush. Out it went, the silver reel singing a merry refrain, the fine threadlike line cutting the water with a hissing sound. The fish headed for the deep azure heart of the channel in some "dark unfathomed cave" to find shelter from this new and unseen enemy. Slowly pressure was placed upon the reel, down went the pliable rod, down to the danger point, the tip fairly at the surface, the reel giving way - ze - ze - ze! - to protect the line, then crying out z-e-e-e-e-e-e! as the fish made a strenuous rush. It was so far away now, 
that the line did not touch the water within thirty feet, and slowly rose with a peculiar rhythmical thrill. Forward went the butt and it was slowly lifted; down dropped the tip, the reel singing of victory, the multiplier eating the line with its marvellous appetite. The fish swam in a semicircle, bearing off, but losing ground, coming in steadily. It soon recognized the situation and, with a lunge forward, turned and plunged directly outward with an impetus that was irresistible, taking back the hard-earned line. The water was comparatively shallow and there was no deep sulking, and as the fish played midway between bottom and surface the sport was intensified by the insistent surging, the great curves, and the repeated plunging ever outward. Again and again the fish was turned by the pliant rod; now to the right, leading it into shoal water, again to the left. And now, as its strength was waning, the reel gained, and soon a great red spot against the blue grew larger, and still making a gallant fight, bearing hard against the marvellous thread which held it, the great fish came to gaff and was ignominiously hauled ashore, its queer little eyes gleaming, its tail beating the water in furious and impotent protest. As it was hauled into a little 
bay among the algæ-covered rocks, the home of the micramoc, it was a striking object; about three and a half feet in length, the body very deep, colored a vivid brick-red, the base of some of the fins black, a jet-black crescent at the base of the tail, a dark inky blotch on the forehead peculiar to the male, while the lower jaw was yellow. Other minor tints and differences between the sexes may be found, but the prevailing color is red, and the catch might better be called the flame fish, as it blazes its way with lurid scintillations, through the blue waters. It is known as hogfish because its mouth is supposed to bear a resemblance to that of a hog; at least, it is very large, and armed with prominent teeth which project outward. The first three dorsal spines are provided with long red streamers, while the first rays of the soft dorsal and anal are very long, which, with the outer spines of the tail likewise extended, give the hogfish a gay and festive air. Preserved specimens, individuals found in the markets, or even in the wells of smacks, convey no idea of the beauty and briliancy of the hogfish fresh from the coral groves, where aeration is perfect and the bottom highly colored. 


\section{The Hogfisb}

The deep-water forms, from forty or fifty feet, are the most beautiful; those which have been in shallows for some time are less pronounced. So marked is this variation of color and difference between the sexes, and old and young, that the unfortunate hogfish has, like others, been named so many times that with the channel-bass it might take the prize as a terrible example of the insatiate pursuit of names and new species. Leopold von Buch, the well-known geologist of Berlin, and friend of the lamented Agassiz, once said, "When I am at Neuchâtel and I knock at the door of Agassiz I am always afraid." "Why?" asked a listener. "I dread," said Von Buch, "lest he take me for a new species." It is only just to say that Agassiz never experimented with the nomenclature of the hogfish. Among other names it is el capitan, and in Jamaica and Porto Rico, perro perro; but among the Conchs on the reef, and the Bahamians, I never heard these names: it was always the hogfish. One of the finest table fishes in America, game in every sense, yet fate ordains it to be "yanked" in, by the smack fishermen, with grouper lines.

The hogfish, of which there is but one species, belongs to the family Labrida (the Wrasse- 
fishes), to the genus Lachnolaimus (Cuvier and Valenciennes), and is known to science as Lachnolaimus maximus (Walbaum). It is essentially a West Indian fish, being more or less common at Cuba, Porto Rico, Jamaica, and the various islands of the Bahamas, and north to the Bermudas, where, at the mouth of Great Sound, on Hogfish Shoal, stands a gigantic facsimile of a hogfish in metal, announcing that there, at least, the hogfish is sufficiently esteemed to be the only game fish in the world to have a monument. Key West and the immediate keys, west to Loggerhead, is a favorite ground of the fish, which for years has been a valuable catch, and always found in the wells of the American fishing-boats, which generally hailed in the old days from Mystic, which provided Cuba with a large part of its fish supply. Exactly why the Cubans should prefer fish from America when the same fish could be taken from their own waters, was difficult to understand by laymen; but formerly the hogfish was supposed to be poisonous and a law prevented its sale. Some fishermen informed me that not many years ago the Cubans believed that there was so much copper in their waters that nearly all the fish 
were poisonous, hence the demand for American fish caught one hundred miles distant.

The hogfish is found in water from four to six or eight fathoms. Where the reef dips rapidly into deep water, and is covered with coral and gorgonias, in a word, is a good browsing-ground, there the hogfish will be found by the discerning angler. While a swift swimmer when occasion demands, it is normally a slow-moving fish. I have often watched it through a water-glass, or from some point of vantage as it poised by some plume, or sea-fan, or slowly swam about, occasionally tipping down with a display of caracoling to take some reckless crab. It has been described as capturing fish, but I never found evidences of this diet in scores examined; the food of its choice is crabs, crayfish, shells of various kinds, as the fan-shell, which it takes from the gorgonias, seaurchins or echini, starfishes and hermit-crabs. In shallow water described, mullet bait would not attract the hogfish, but conch or crayfish, crab or squilla, was especially to its taste. The deeperwater fishes appear to be more democratic. The hogfish is always to be found in the localities of its choice. In winter it undoubtedly moves into water slightly deeper, at least in summer more 
were seen on the shallow reef mentioned; and as several were taken in seines at night in the lagoon, in water from three to five feet in depth, the fish doubtless came in at this time to feed upon crayfish, which were then in the open, and the large white short-spined echini found there. Little is known of its breeding habits. Young two inches long were taken in August in the lagoons, and it was supposed to deposit its spawn in water fifteen or twenty feet deep just outside the breakers; but this assumption was obviously not justified by actual observation. Females with spawn were taken in May and June.

The hogfish is rarely caught by anglers who fish with the rod, as almost the entire fishing is conducted or carried on in deep water, and it is necessary to go out in the smacks and fish for them, à la cod, with a hand-line - not a satisfactory proceeding to the man who has been trained to look upon the hand-line as a device of the pot-angler, which is hardly true. The strongest argument against hand, or cast-line methods is that by them the fisherman can take too many fish.

Found with the hogfish in the new American possession of Porto Rico is a fish known as 
robalo (Centropomus), which attains a length of three feet and bears some resemblance to a walleyed pike with the lower jaw of a barracuda. It is a gamy hard-fighting fish, and local sportsmen go to the Rio Plata for the purpose of taking it. On the Texan coast, on sandy bottom, is found another species, $C$. undesimalis (Bloch), which attains a length of four feet and a weight of twenty or thirty pounds. I fished in vain for it in the vicinity of Aransas Pass. Singularly enough, this fish is rarely found on the outer Florida reef, at least, I saw but one individual; but there were numbers of fishes there which undoubtedly were present all the time, for some reason seen but once or twice, even when fishing or drifting over the reef was a part of almost every day's experience. It is not safe to exclude a fish from a locality because it is not caught. Many of the game fishes described in contemporary works are underestimated as to size, for the reason that descriptions are often made from market specimens, or from specimens in alcohol, in either instance large specimens not being desirable. There are numbers of fishes on the outer reef from four to ten pounds in weight which, if taken with light rods, afford fine sport. In this class I would in- 
clude some of the grunts, all the small snappers, the parrot-fishes, the large angel-fishes, and large (sea) gars. I have had the latter on a fly-rod leap into the air and play with all the fervor of a trout; yet there is a prejudice among anglers against many of these fishes. 


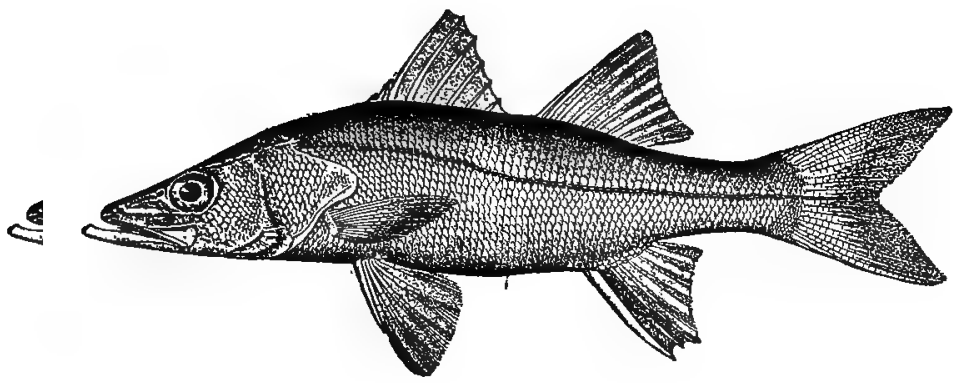

SNOOK; SERGEANT-FISH

Centropomus undecimalis (Bloch)

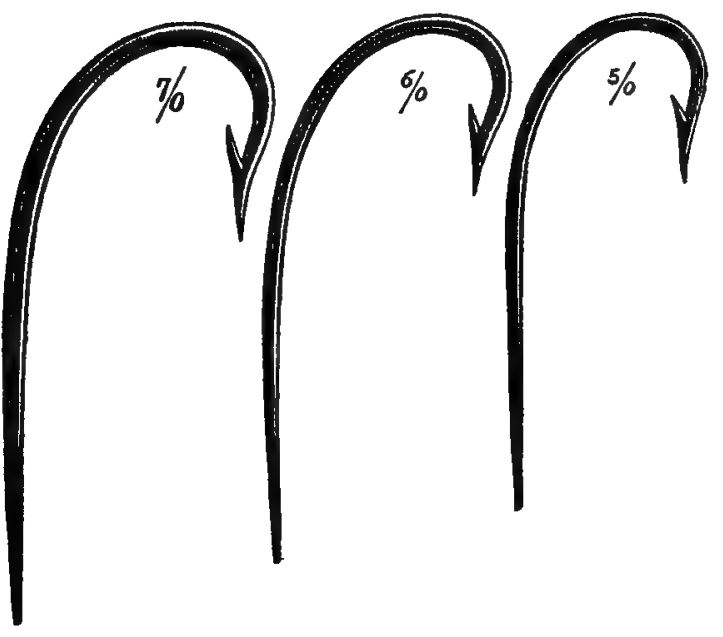

HOOKS FOR YELLOWTAIL OR WHITE SEA-BASS AND BLUEFISH 



\section{CHAPTER IX}

THE YELLOWTAIL

"The pleasantest angling is to see the fish cut with her golden oars the silver stream and greedily devour the treacherous bait."

- SHAKESPEARE.

When the green tones of Southern California merge into gray, and the islands alongshore rest like emeralds in settings of azure, the yellowtail, the gayest cavalier of these summer seas, often tints the ocean a golden hue as the vast schools tarry in the shadows of the island mountains following their short migration. The yellowtail is the fish of the people. It is willing to try conclusions with the veriest tyro when it is in the biting humor, and can be caught with almost anything; but when not excited, when in its normal condition, with a bold and unaffected camaraderie it disdains the arts of the cleverest wielder of the rod and literally defies him to his face, often at mere arm's length.

I have taken the yellowtail nearly every month in the year in the Santa Catalina channel and at 
Santa. Catalina and San Clemente islands, but this is exceptional, as the months of January and February, as a rule, know it not, at least in shallow water, and the angler who would take a yellowtail at this time must search the deep San Clemente channel, six hundred feet down, or the Cortez Bank south of Santa Catalina, where there is every reason to believe the yellowtails, or a certain percentage of the schools, lie not far from the sardine and smelt schools, which also mysteriously move out at this time. In March a few yellowtails appear at the islands, and in or about the first of April, sometimes sooner, sometimes later, what is known as the first run comes, and the bay of Avalon is often alive with fishes and boats, and the shouts of laughter and disappointment as the fish play havoc with the rods and lines of the tenderfoot. Not many years ago I was at Avalon when this spring "rush" occurred. Without warning a large school of yellowtails ran a small school of smelts in on to the beach, then out again, breaking them up in a masterly manner until the entire charming bit of water was a mass of foam. The yellowtails averaged twenty-five pounds at least, and a cyclone appeared to have struck the quiet bay. 


\section{The Yellowtail}

Men, women, and children were seized with that mad contagion, the desire to fish, and hurried to the beach with lines which were cast with shouts and laughter, and in a short time the shore was a beating, leaping mass of yellow, green, and turquoise. Then the excitement grew fiercer. The man with the rod determined to be a sportsman under all circumstances, and cast over the hand-lines. The fish of one angler ran around the lines of both and into the field of a third, and in a moment the line of fishermen and fisherwomen were engaged in a war of words. Every available boat was soon rowing about the bay in every direction, many of which would have one or two fishes on at the same time, presenting a most animated spectacle.

The feature of this unusual and remarkable scene, which found its prototype in the "jack beat" of a following chapter, which impressed me most, was the strength and game qualities of this particular school of yellowtails. Nine-tenths of the people were fishing with hand-lines, and so numerous were the boats on the little bay that it seemed impossible to use rods. The lines were of the codfish variety, ropes more or less, yet I doubt if a single member of this fishing 
babel failed to lose from one to five fish from broken lines. The heavy line would be broken fairly by the lunges of the fish, which jerked small boats about and turned them with incredible ease. For half an hour this commotion lasted, and when the counting came the fishermen, who had strikes as soon as the bait struck the water, found that some had secured four or five yellowtails; but the average fisherman had landed one or two and lost from five to six hooks and as many fish. This incident is introduced to give some idea of the yellowtail when at its best, and pound for pound it is one of, if not the best fighter in the Western seas; if it could be taken in shallow water, it would put the salmon to blush, as a past master in the finesse peculiar to game fishes. This was some years ago; to-day the splendid fish is rarely taken with a hand-line. I suggested the Tuna Club and its rules for rod-fishing with the lightest lines as a measure of protection to this fish as.well as others of these waters, and to the example of the members of this organization is due the high standard of sport which now holds.

We have seen that the first run of yellowtails comes in April. This may last, so far as the 
angler is concerned, two or three weeks, then will come a cessation of biting, though this is by no means a hard and fast rule, rather a general average in my experience. In May, and from then on, the yellowtails are about the islands north to Santa Barbara in vast numbers, and have come for the season, which is of about nine months' duration. They apparently come in small schools; then break up and are found in bands of greater or less size all summer; in the spawning time in pairs at the surface, refusing the daintiest lure. The fishes sweep up the entire coast, reaching offshore to San Clemente thirty-five miles, and occasionally are caught as far north as Monterey; but the approximate northern limit, so far as the angler is concerned, may be considered to be Santa Barbara, the fishing. ranging far to the south being particularly fine in the vicinity of Ensenada and the shallow bays of Lower California.

As the yellowtail enters the Santa Catalina channel the charms of the island of that name and San Clemente with their abundant food supply capture it, and the actual rod-fishing of Southern California may be said to focus about the region of which these two islands, twenty 
miles apart, are the centre, giving about one hundred miles of coast-line, bays, and coves for the angler, one-half of which will be found smooth water - that rarity on the Pacific coast. The yellowtail follows up the mainland coast-line and can often be taken two or three miles off the beaches from Coronado north; and at ports like Redondo, where deep water cuts inshore, it is sometimes taken from the high piers. At the islands offshore the north or east coast is the lee, and does not experience the heavy trade-winds; and here is the home of the yellowtail, the waters in which the angler finds conditions far out to sea which call to mind some inland lakes. A large percentage of the visitors to these angling islands try conclusions with the gamy yellowtail, and as a consequence, boats and boatmen peculiar to the place have developed. The typical fishing boat is a sixteen or twenty foot yawl or launch with a two or four horse-power engine run by the boatman, who is also gaffer and an expert in his calling. The boat has two chair seats at, and facing, the stern. Attached to the seat is a cup of leather to receive the butt of the rod when a large fish is being played, while overhead is an awning, lifted when the strikes come by the 


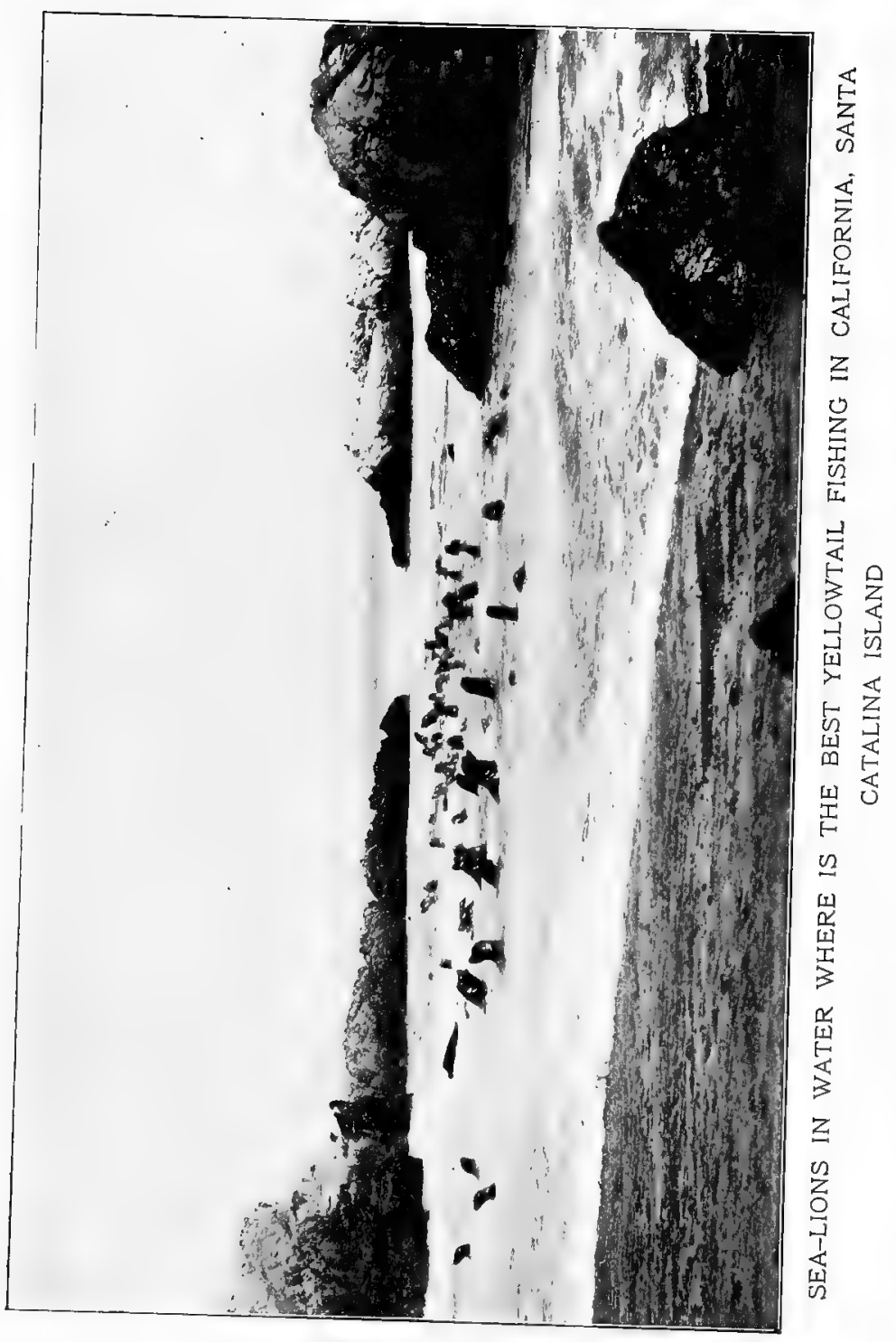



boatman, or if the angler desires he can stand and play his fish.

The shore of the islands is remarkably abrupt, rocky cliffs, rising sheer from the sea, and almost anywhere a ship would strike the rocks with her bowsprit before she would ground. To this is due the close inshore fishing, as it is all within from ten to two hundred feet of the shore. The island is skirted by a fringe of kelp at various points, and just beyond this is the yellowtail highway where the splendid fish sails up and down to the delectation or confusion of the angler. The equipment for yellowtail is one more or less of fancy. I give my preference, and can only say in defence that it has been eminently successful, owing perhaps to the proverbial fisherman's luck. The rod of noib wood, greenheart, or split bamboo is from seven to eight feet in length and weighs not over twentysix ounces, pliable, yet sufficiently stiff t) lift a sulker of thirty pounds if perchance the occasion demands. The line is a twelve or fifteen strand cuttyhunk, or some equally good make, and there should be three hundred feet of it; the hook, a 7/o O'Shaughnessy, though a larger size is more popular, with a six or eight incir 
piano, bronze, or copper wire leader in two links. The leader should be fastened to the line with a double swivel. The bait is either smelt or sardine four to six inches in length. The hook enters the mouth, coming out at the gill; then turned, is embedded in the belly of the fish, so that the entire hook, except the upper shank, is concealed. The mouth of the sardine is now wound or closed with a five-inch, very fine silver wire which is attached to the shank of the hook. This is an important feature, as it prevents the bait from whirling too rapidly, which often results in ruining the line by unwinding it. I have never been able to take the fish with a spoon. At times, when the fish are fickle, I have found a large flying-fish very effective as bait, trolling slowly with a light pipe sinker sufficient to take the bait down twenty or thirty feet. This is an extraordinary bait for the fish, being ten inches in length, but it frequently results in the capture of exceptionally large yellowtails that seemingly find it irresistible.

Thus equipped the lines are unreeled for fifty or sixty feet and the launch, or rowboat, moves slowly along the line of kelp with a rod out on either side. The fishing is best in the morning, 


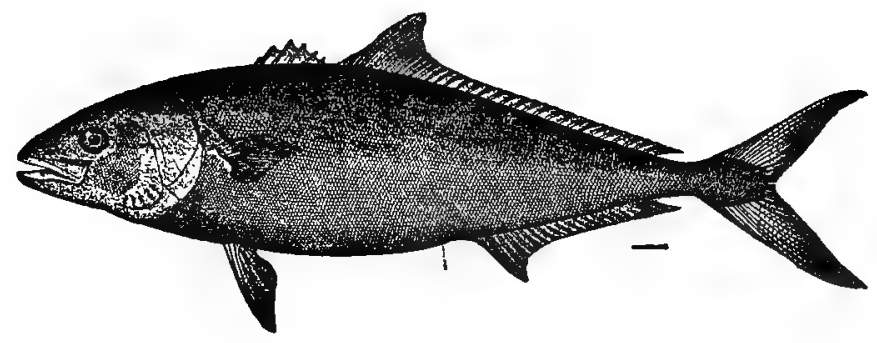

YELLOWTAIL, OR AMBER FISH

Seriola dorsalis

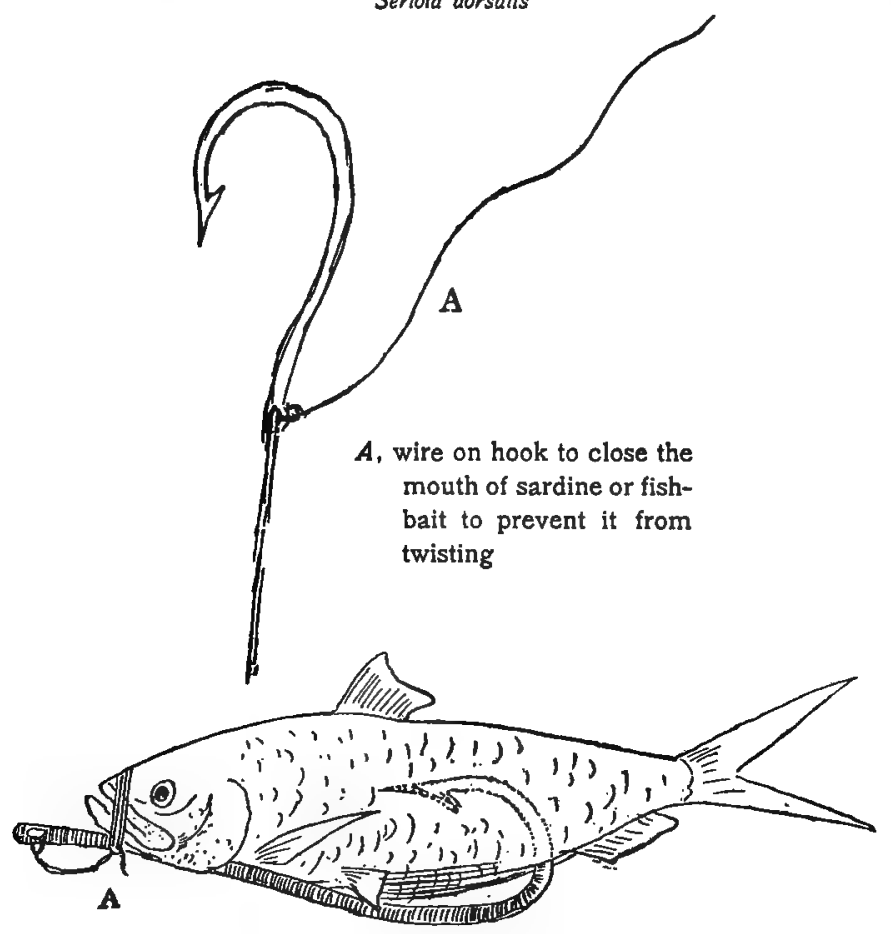

Sardine or herring baited for Yellowtail or White Sea-bass trolling, showing method of impaling fish.

(A) Copper wire for lashing the mouth of the bait-fish 

from sunrise to midday, on the flood-tide, and, as a rule, the angler finds smooth water, with ripples here and there breaking the surface, telling of vagrant schools of yellowtails or sea-bass. The water itself is a revelation; it has a splendid tint, dotted with living constellations of marvellous shapes and design: crystal chalices, jellies with fluted cometlike tails of maroon and deep lavender, while scattered about with a lavish hand are the gems of the sea, Sapphirince, flashing the tints of mimic rubies, emeralds, topazes, diamonds, and other gems. The angler must be callous indeed who is not charmed with this divertissement, captivated with these beauties which, like sirens, claim his attention until arrested by the loud zeee-zeee! of the reel as it gives tongue behind the rush of his first yellowtail. A shrill staccato, and fifty, one hundred feet of line have perhaps gone before the novice presses the leather pad, with which all reels are equipped, and essays to arrest the fierce outward rush. At the first click the boatman stops the engine, and the yellowtail now tows the boat around, as it rushes here and there making battle so desperately that the angler is easily wearied.

There is something so startling about the first 
rush of the fish that the nervous holder of the rod is sometimes stampeded. A fisherman is perhaps seized with "buck fever," under its influence, and drops the rod utterly demoralized. Others cannot take in the fish, and lose fish, rod, and line. The yellowtail makes a number of desperate lunges, so vigorous that there is really nothing to do but to give line. If the angler can withstand it, then the rod is too stiff for the code which holds and is most in favor. The line is kept taut and reeled when opportunity offers, but if the fish is a normal one and full of vigor the angler will find the latter impossible to reel in as one would a bass or lake-trout, and it is here that vertical or lateral "pumping" comes into play; and that it is absolutely necessary every one who has tried conclusions with the fish will acknowledge. I have seen a novice work upon a seventeen-pound fish for nearly an hour attempting to reel it in out-of-hand. At the end of half an hour the man was weary, while the fish appeared to be gaining in vigor if the click was a true prophet. Pumping, it may be explained to the uninitiated, is the invention of some unknown patron of the sport, which enables one to lift a deep-sulking fish, accomplished in the following 
way: The tip of the rod is lowered to the surface, then, pressing the thumb upon the leather pad, the fish is lifted with all the strength the line will bear, the angler always watching for the rush which invariably follows, and when the tip is raised three or four feet, it is suddenly dropped, the slack so gained being reeled in as rapidly as possible; then the fish is again lifted and the operation of "pumping" repeated indefinitely, or until the sulker is brought into sight. With experience or practice this becomes an easy by-play, and the fish can readily be brought up. The angler gazing over the side now sees a dazzling object of silver careening across the line of vision deep in the azure heart of the ocean. Up it comes, now dashing along, causing the boatman to row the boat around in desperate attempt to keep the stern to the fish. As it comes higher, or nearer, making gallant play, the old hand prepares for what is perhaps the most desperate rush of all, and it comes with a loud barcarole from the reel.

Ten minutes have slipped away before the boatman begins to finger his gaff, then the angler reels the fish "in short," passes his tip forward as the fish turns, protesting, ready for another 
rush, its heart still strong, the cruel gaff slips beneath it, is jerked into the silver throat, and the struggling fish lifted in. Such a moment is an epoch in some men's lives. Thirty-five pounds is the gaffer's report, and the fish he holds up to the admiring angler for inspection is a magnificent specimen, the type of a game fish, nearly four feet in length, well proportioned, with lines like those of a privateer, a large head, yet not too large for the body, a radiant and large eye. Along its back is a long dorsal fin; the tail is forked, powerful, and a vivid yellow which is carried out in a stripe along the median line. The upper body color is an olive-brown in the water, changing in the sunlight to the most brilliant blue iridescence, the belly silver. Such is the general appearance of this prince of game fishes that dominates the quiet seas along the isles of summer.

Like other popular fishes the yellowtail rejoices in a number of names, among which is the white salmon, a sad misnomer, the amber-fish, which has some significance, and cavasina, while its generic name, Seriola, is euphonious. Its nearest relative is the little pilot-fish, Naucrates, which bears a strong resemblance to the young 
Seriola. Seriola dorsalis (Gill.) is the large Pacific species. The fish attains a length of over four feet, and I have seen a specimen which weighed eighty pounds dressed, which suggests a one-hundred-pound fish as the maximum; but this is very rare, at least in the Santa Catalina fishing-grounds, where the yellowtail is best known. The average rod catch is from seventeen to twenty-five pounds, though I have seen a sixty-three-pound fish taken from the wharf.

The yellowtail spawns in August, that is, fish with spawn are seen and caught at this time; but the smallest yellowtail I have observed in these waters in sixteen years weighed about seven pounds, the very young never being observed there. I understand they are caught in the bay of San Diego and farther south. On one occasion only have I seen a school of young yellowtails, and these must have averaged ten pounds each. The very young yellowtail bears a strong resemblance to the little pilot-fish, and is banded with ten dark, more or less cloudy stripes. The fact that the young are not seen at the islands is by no means evidence that the fish do not spawn here, as a similar instance is seen in the black seabass. Almost every bass taken bears enormous 
masses of ripe spawn; but the very young have never been observed, at least by me or by any professional fisherman known to me.

Like others of their kind the yellowtail is fickle, and at times the sea will be fairly tinted with them, and vast schools divide as the boat moves along, yet the choicest bait is viewed with scorn. At such times the resources of the angler are tested. Bait is changed, pipe sinkers of various weight tried, the speed of the boat varied. The yellowtail will perhaps swim up to within a foot of the boat, following in the bait, then turn, saluting the angler with a blaze of color. A conscientious "chumming" may now be tried and, if the school is swimming about slowly, the boat may be rowed or steamed slowly in a circle, the boatman throwing over small sardines on either side, six feet apart. By the time the circle is completed a chain of yellowtails has been established, all feeding, as they will take "chum"; and if the angler is patient, he can in many instances break the charm, and once biting, sport is assured.

It is a theory among some boatmen at the islands that the yellowtail fishing is best from May to August on the south end of the island and trolling in order, and from then on, at the 
north end with casting or still fishing. In the latter the boat is allowed to drift and the yellowtails kept alongside by chum, short casts being made of thirty feet. In this way at the grounds off Ship Rock I have seen yellowtails hooked almost as soon as the line struck the water. Perhaps the most satisfactory method of yellowtail fishing I have observed was from the beach at the Isthmus, the shallow bay preventing sulking, the rushes and by-play being confined to lateral movements.

The yellowtails are omnivorous feeders, taking sardines, flying-fishes, smelt, anchovies, and squid as occasion offers, and in this way they are often "chummed" up and caught by casting, the boat being allowed to drift. The remarkable cleverness of fishes has often been noticed. Certain individuals will attach themselves to the wharf at Avalon at times, and one of the morning pastimes is to feed them by tossing over bait. A handful of sardines will sometimes attract a number which rush at them, picking up the fishes with avidity, invariably not noticing the hook which has been skilfully introduced into one sardine. It is only the extremely patient fisherman who can catch such fish. One veteran 
of the wharf was hooked to my knowledge five or six times, bearing two hooks proudly in its jaw, and trailed three feet of line. I hooked the same fish twice within two hours, and each time it broke the line by clever tactics. Its first rush was away, then, feeling the line, it invariably turned and came for the wharf like a race-horse, dashing about the piles and severing the line, almost immediately reappearing in its accustomed place by the side of the pier, up and down which it slowly swam in full view of the assembled anglers.

That some fishes have an attachment for one another I am confident. A hooked yellowtail, in its attempts to escape, after exhausting all methods dashed down and squeezed under a hawser in twenty feet of water, so completely fouling itself that it could not move. I could see the unfortunate fish distinctly, and close beside it poised its mate or comrade of the same size, apparently endeavoring to aid it in escaping; and during the long time I watched the two fishes, the free yellowtail remained by its entangled mate.

Singularly enough, the yellowtail, the commonest fish in the Pacific, is not in great demand as a food-fish, and few are eaten, owing to some unreasonable prejudice, as when properly cooked, 
especially boiled, it is excellent, and in any other section of the country would have a decided economic value.

The genus is well represented on the Atlantic and Gulf coasts of America by several fine game fishes. One, the amber-jack, Seriola lalandi, deserves especial mention. I have landed but a single specimen, which weighed forty or more pounds, taken at Long Key, outer Florida reef, since, I understand, washed away by a hurricane. The fish attains a weight of one hundred pounds and a length of six feet, and is a vigorous fighter. An acquaintance who caught one of these fishes weighing eighty pounds, at Palm Beach, informed me that he fought the fish two hours before it was brought to gaff. The amber-jack ranges from the region of the equator to New York, but is most common from Cape Florida to Key West, at least most available to the angler. Many are caught with hand-lines and mullet bait.

A smaller yellowtail, also called amber-jack, is found along the Gulf coast of Florida and down the keys, frequenting deeper water, and is occasionally taken when grouper fishing. There is another yellowtail, not to be confused with the above, yet essentially the yellowtail of the reef, 
known to science as Ocyurus chrysurus, and at Porto Rico as colirubia. It is a dainty, radiant creature, one of the most attractive of all fishes, nor only with yellow tail, which color constitutes the base from which radiate rays of golden lines, splashing and blotching it with color. Its eye, like that of the large Seriola, is an object of beauty, clear, bright, black, and vivid red. I have taken it off the great fringing reef of Garden Key by casting in among the waving gorgonias - a fitting home for so beautiful a creature, and can commend the fish, which attains a weight of eight or even ten pounds, to the angler with an eight or ten ounce rod, the lightest line, with a number three O'Shaughnessy hook with a three-ply twisted gut leader and no sinker. Such an equipment with fresh crayfish bait will afford the angler much delightful sport.

The relative game qualities of the same fishes of different size is an interesting subject. The yellowtails of all sizes are good fighters, and by varying the size of the rod and tackle the angler can obtain full enjoyment from all. In my experience the yellowtail of seventeen or twenty pounds is as a rule the hardest fighter, many very large fishes not possessing the agility and activity; 
and except in rare instances this holds good among all fishes, the fish of medium size being the gamiest. In fishing for yellowtails one is impressed with the truism that the act of capture is a very small part of the angler's pleasure. In the one case, he has in the California islands cool days, smooth and beautiful water, attractive surroundings, rugged cliffs, and the many beauties of nature as solace if luck is poor. On the other hand, when trolling, following the amber-jack along the Florida keys, he is floating over veritable gardens of the sea, which flash every color of the rainbow, along sands which form the settings for growing keys which, like pearls, are strung along the Mexican Gulf. 


\section{CHAPTER X}

\section{THE BLUEFISH}

"Fisherman. Master, I marvel how the fishes live in the sea. Master. Why, as men do a-land : the great ones eat up the little ones." - Pericles.

Not far from the isle of Patience, in Rhode Island waters, an old longshoreman and fisherman once informed me that he had taken one hundred and forty "horse-mackerel" in a single day. In Georgia at the mouth of the St. Mary's not far from Dungeness, my sable boatman told me of the delights of "skipjack" fishing in the proper season. The retired New Bedford whaler, who fishes near there, will show you a rod bent by "snappers," and the Jamaica Bay angler esteems himself in great good luck when he makes a catch of "skip mackerel." I offended the $\mathrm{Pa}$ tience Island fishermen by intimating that one horse-mackerel a season would be considered a good catch by some people, and then he produced the game. It was a bluefish. So, in Georgia, the 
bluefish was the skip-jack, and in all these localities it was the same hard-fighting, bluff, linebreaking, hook-taking, devastating bluefish, not travelling under an incognito, but having alias upon alias forced upon it by the fishermen and beach-combers alongshore from Maine to Florida. Even the most rigid adherents of the school of rod fishermen, who look upon the handline as a contrivance of the pot-hunter, will have to cry peccavi, when the bluefish is mentioned, as the largest number of these gamy creatures are taken with a hand-line, and find the ruthless slaughter which they carry on among the small fry turned upon themselves. No one can deny the fascination of the sport; the fresh wind, the rushing boat, the skipper sitting on the edge of nothing to windward, to hold her down, the angler from the city perchance lying in the lee scuppers holding on for dear life, his arms wrenched and chafed by the gamy fish which seems to be in league with the "old man" at the helm to complete his demoralization. But when the same ancient mariner has had his joke, and luffs at the strike, then there is sport for the hand-liner, who, seized with the lust for killing, plays and is played, with shout and laughter. 
No one can watch the bluefish amusing itself at the expense of a party of dry-land fishermen but is convinced that this blue-backed, slashing creature is the fish of the people. Off Newport and all along the coast the bluefish has been successfully fished for with rod and reel, and I have enjoyed the sport at Fisher's Island, off New London, and am convinced that if proper boats were employed, after the fashion of the yellowtail and tuna launches of California, bluefishing with a rod would become as popular as the quest of the striped bass among the islands of strange names, of which Cuttyhunk is the most familiar.

My first attempt to take a bluefish with a rod was disastrous to the rod. The current at Fisher's Island was particularly fierce where the fish were biting, so that a rowboat was impossible; and, with a stiff breeze, I had my boatman beat up and down across the tide-rip, which reminded me, in its intensity, of the "rip raps" at Old Point Comfort, or "Pull and be d- Point" at Portsmouth. The water was clear and beautiful, aerated with constant whitecaps, hence exhilarating to the fish, which were evidently feeding, breaking water here and there. I had the mainsail triced up so that the main boom, from a distance, looked like 


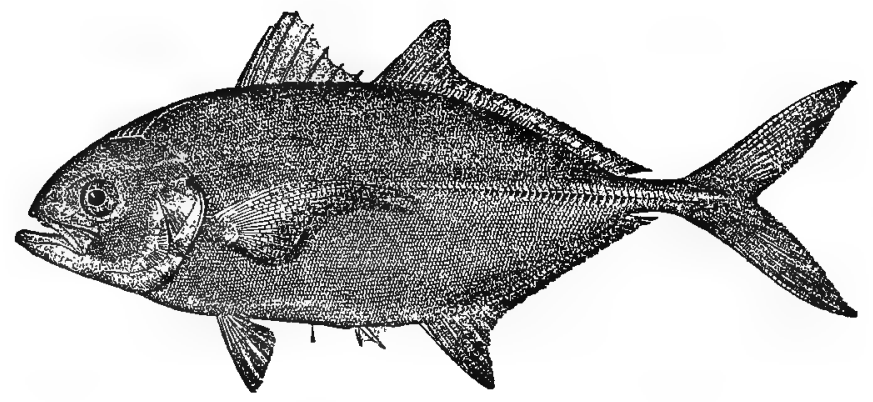

HARDTAIL; " RUNNER "

Caranx crysos (Mitchill)

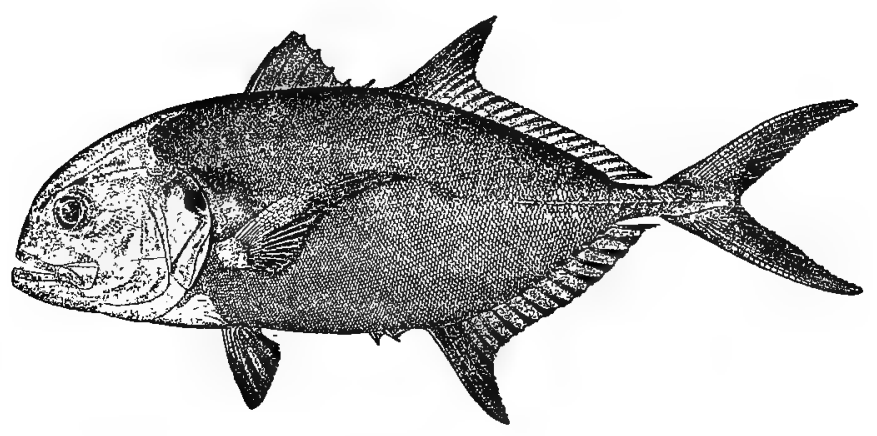

CREVALLE: "CAVALLY"; "JACK"

Caranx hippos (Linnæus)

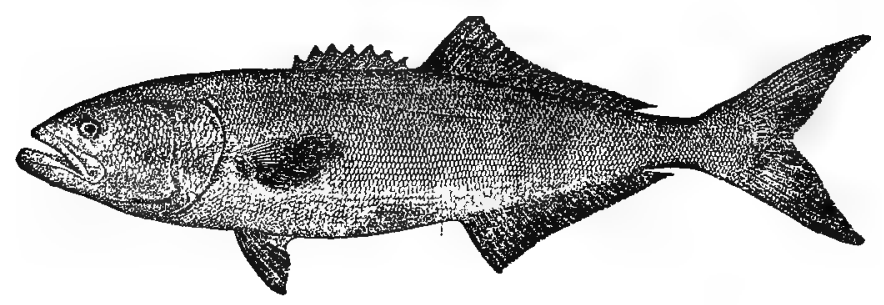

BLUEFISH

Pomatomus saltatrix (Linnæus) 

the topgallant yard of a three-master; at least, it cleared my head when it swung around. My rod weighed twenty-six ounces, was eight feet long, with a far too slender tip, and was rigged with a number twelve cuttyhunk line, which would pull a dead weight of twenty-two pounds. The skipper had orders to luff at the strike and hold her in the wind until I brought the bluefish to gaff - this is a well-planned theory, and, as the boatman said later on, "it looked all right." Presently we were bounding over the water, the silvery bait flashing from wave to wave sixty feet behind. We had reached halfway over the "rip," the little catboat flying along, lee scuppers under, with a big bone in her teeth, the skipper, with one hand on the tiller, and the other grasping the main-sheet, ready to slack away when the strike came - the reel screamed, "luff! luf-f-f-f-f!" shrilly, then madly, and up into the wind came the boat, caracoling, shaking her sails, and making a prodigious protest at being stopped in so ruthless a manner. But all was not well with me; the bluefish had made a prodigious rush, and aided by the speed of the boat, literally ran out my line, and, despite a desperate effort to save it, took line and tip. But there were more lines, more tips, and more 
bluefish, and the next time we close-hauled the cat-boat, ran her into the very eye-teeth of the wind, against the current, and at the strike pushed her into the wind, and let the main-sheet run; and then I was initiated into the delights of real sport with the rod. No fish makes a better or more vigorous fight, pound for pound. Amid the clanking of boom, the tattoo of reefing points, the jangle of the block along the traveller, I played the bluefish. How it played and bore away! What mad rushes it made in and around! now far away at the surface, where the dark green waters rolled in silvery laughter; now plunging off, forcing the fight, and making the reel sob and cry. For ten minutes I played this gallant fish, and when at last it came in, I was forced around the mast and under the sheet several times to meet its circling; finally it came to gaff, fifteen pounds of vigor and unsuppressible animation.

The bluefish is one of the gamiest of American fishes with a rod, but rods and a sail-boat rarely agree, and the strain on the nerves of the average angler, not to mention the skipper, who is expected to luff at the right moment, is too great. With an eighteen- or twenty-foot four-horse-power 



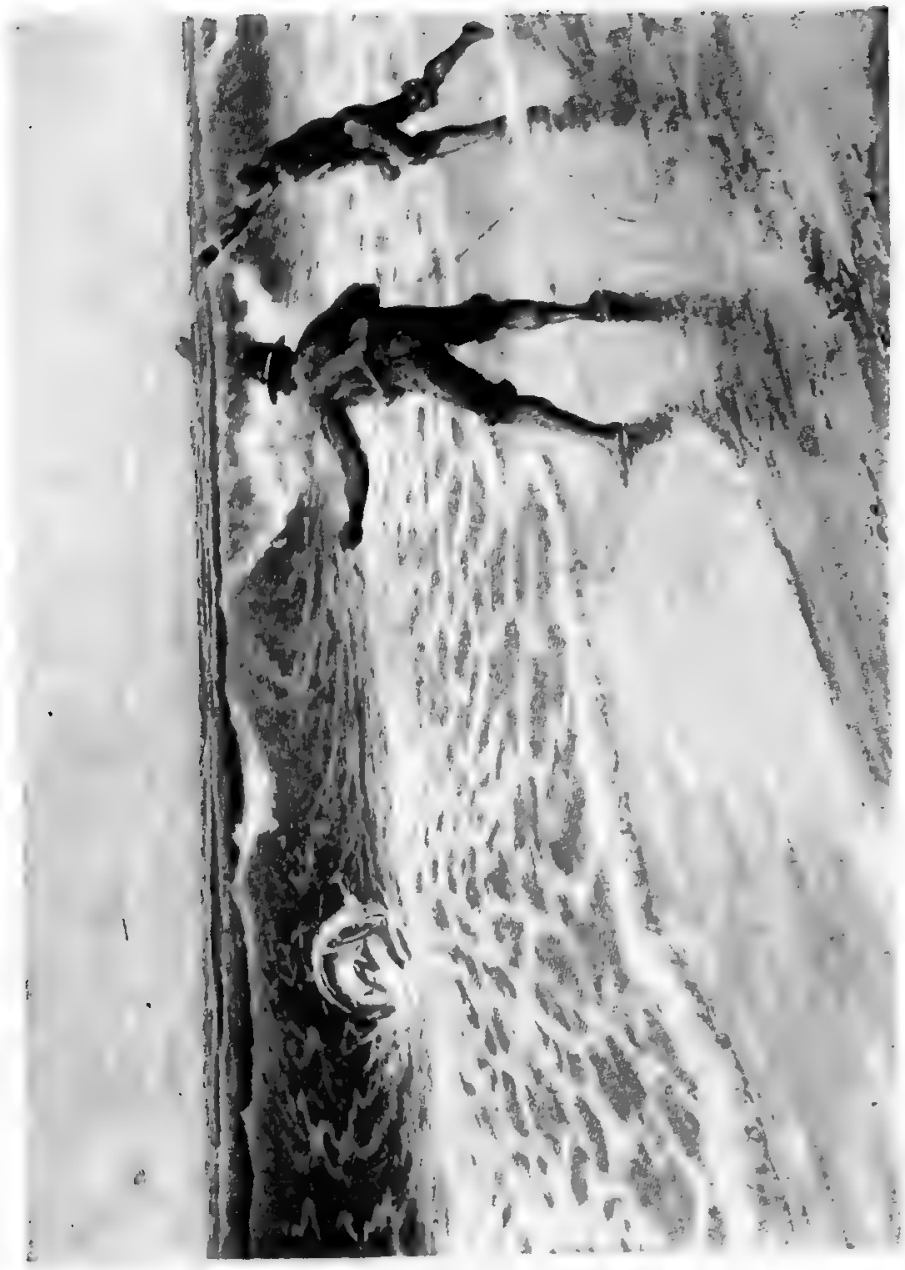




gasolene launch, built light, with a canvas hood, which can be used forward, rigged with two chairs facing astern, resting on a plank on the rail, bluefishing with a rod could be enjoyed, and would become a popular sport around southern New England, as such a boat can be stopped and reversed almost immediately.

There is something infectious and extremely exciting in bluefishing, no matter how taken. The big cat-boat off Nantucket, with two or three lines astern, and a large party of men and women all eager for the fray, bright eyes sparkling, red cheeks splashed by the dashing spray, the shouts of laughter, the hissing of lines through the water, the beating of powerful tails on the planks, are all features which add to the gayety and joy of life and in making it worth living, especially when fish are biting and bait is plentiful. The bluefish attains a weight of thirty pounds, possibly more, and the record catch with a rod, according to the Forest and Stream, is a twenty-five-pound fish, the fish being taken by L. Hatherway, from the bridge at Cohasset Narrows. The bluefish is now caught with rod and reel wherever found in this country, and as the young at nearly all ages are equally gamy, the 
angler has a wide range from "snappers" of two or more pounds with a fly-rod, to eight pounds with a bass rod, adapting his tackle to the size of the game at hand. In trolling, the jig is used - bone or metal, menhaden or any silvery fish, or even a white rag. Along the Jersey shore and many wide sandy beaches they are caught by casting far out beyond the breakers, the men running the fish in with the line over their shoulders as soon as hooked. Others, again, at very favorable localities, wade out and cast with rods, but the best rod-fishing is in some locality where the boat can be rowed by a boatman or anchored near a tide-rip, when the angler can cast his menhaden or sardine out into the water, and by reeling in hook the gamy fish.

The bluefish is a comely creature about three feet in length, long, fairly slender, with a robust, well-proportioned body, the dorsal fins low, the tail large and powerful. Its color, as the name indicates, is blue above, appearing green in the water, and bright silvery below, and altogether a beautiful fish, the embodiment of vigor, grace, and pugnacity. It belongs to the genus Pomatomus, and has many synonyms, twelve at least, and is now known as Pomatomus saltatrix (Linn.). 
It has a wide geographical range, being found from Nova Scotia to Brazil. It is a common fish in Australian waters, in the Malay Archipelago, and off South Africa. Its movements are singular and erratic. Thus, in the Mediterranean, it is caught at Algiers, but is rare on the Italian shore. It shuns the Atlantic coast of Europe in the latitudes in which it is common in America. It never crosses from Florida to the Bermudas, and it apparently avoids the islands of Cuba and Porto Rico. Doubtless it disappears from certain localities, reappearing again only after many years. Thus, so far as known, it was not chronicled north of Cape Cod prior to 1837 .

The bluefish moves north or south according to the weather. It appears along the shore of Delaware, Virginia, and New York in May, gradually reaching the higher latitudes as the summer approaches, and remains until October. During this period it moves in large schools, feeding on menhaden, squid, and various fishes allied to sardines, herring, and mackerel, and is so voracious that it is a factor to be considered in the depletion of bait fishes. I have seen bluefish charge a school of small mackerel, leaving 
the water filled with silvery fragments which sank like stars in the blue sky of the ocean, to be picked up by hungry dogfishes attracted by the slaughter. The bluefishes seemed, like "jacks," to eat what they wished, then, crazed by the excitement of the chase, amused themselves by biting the fleeing victims for the mere wanton pleasure of killing. Such a killing can often be recognized from a distance by the flying foam and the vociferous notes of gulls which hasten in that direction. The enormous numbers of bluefishes off the American coast in midsummer are beyond computation. Professor Baird refers to a thousand millions, and to afford some idea of their voracity he says that if each one eats ten small fish per day, then ten thousand millions of small fry are needed to supply the daily commissariat of this fast-moving army. The fisherman in "Pericles" who wondered how the fishes of the sea lived, doubtless had never been a bluefish fisherman.

Considering the vast number of bluefish very little is known regarding its spawning. On Cape Cod and at Nantucket the fishermen believe that it spawns in midsummer, depositing its spawn on the clear sandy bottoms. G. Brown Goode 
suggested that they spawned late in the year, as small bluefish were seen at Beaufort in December; but the question is an open one. About ten per cent of the young of each fish are supposed to attain maturity. When about fourteen inches long the weight is a pound. A fish two feet in length will weigh about seven pounds, and the early spring fish often range from seven to ten pounds in weight, larger and more robust specimens appearing later in the season. As to the spawning habits of the fish in the Gulf of Mexico there is more definite data. According to Mr. Stearns it is very abundant on the Gulf Stream coast as far west as the mouth of the Mississippi River. It arrives in April or the last of March, there being several distinct "runs." The first to arrive are smaller than those coming later. Then, every fish Mr. Stearns found in spawn, and that it is deposited at this time, in the months of May, June, July, and August, he is confident, as he has caught young bluefish in June and August not over three-quarters of an inch in length. In June nearly all the adults disappear from view, and in November and December the young fish are seen to pass through the inlets and go to sea. 
At this time fishes ranging from three and five inches to fifteen inches are observed. In observations covering six years I never saw or heard of a bluefish on the outer reef.

The bluefish is a valuable food-fish - one of the most delicious table fishes in America. After being kept or frozen, its delicate flavor is, to a certain extent, lost. Over eight million pounds of bluefish are consumed annually, valued at about half a million dollars, and all alongshore wherever found they rank high as game or food fish, or both. 


\title{
CHAPTER XI
}

\author{
THE JACK \\ "But why, good fisherman, \\ Am I thought meet for you, that never yet \\ Had angling rod cast towards me ?" \\ - Moll Cutpurse (r6rr).
}

Long John, Bob Rand, Paublo, and Chief, the Seminole, all clever with the grains at long range, and with the cast-line, were the authorities at Garden Key, on the Florida reef, and as I unfolded a rod one evening in their rangy quarters, and announced that I was going to fish with it, they looked at me in such undisguised amazement that I assumed that a piece of "machinery" of the kind had never before been seen on the key of the gulf. In the summer months particularly, the various channels of the reef were the favorite haunts of the jack (Caranx hippos), one of the gamiest fishes that swims the Southern seas.

The keys dotted the blue gulf like emeralds; masses of green bay cedar encircled with white 
coral beaches, apparently floating on the waters, possessing a charm peculiarly their own. The air was as soft as velvet to the cheek, the days clear and beautiful, and the atmosphere had a strange resonance as though the blue vault of the heavens was a sounding-board which made every sound bell-like and distinct. The distant roar of the surf on the outer reef, the grinding of the dead coral rocks as they were tossed hither and yon by the waves, the far-away "ha-ha" of the laughing gull, the crash of the big ray as its winglike fins struck the water, all were heard with extraordinary distinctness by the angler drifting in lagoon or channel. This explains why the jacks invariably summoned me to the sport, which for excitement and novelty it would be difficult to exceed.

In my initial experience $I$ was a fourth of a mile away when a sound like the pattering of rain came softly down the wind. Louder it grew, changing into a ringing, rushing noise, then into a roar.

"Don' yo' hear it, sah?" whispered Chief, resting on his oars, allowing the dinghy to drift.

I turned in the direction of the sound and became witness to my first "jack beat." The 
lagoon was a sheet of glass, a dead calm having taken possession of the gulf, as far as the eye could see. Here and there the knifelike fin of some vagrant shark cut the water, or a billfish went ricochetting along, the only disturbing elements; yet near the shore-line of a long attenuated key of white sand, the waters were beaten into foam, amid which scores of bodies were leaping. It was the jack, or cavally, the horse crevallé, as it is known from Cuba to the Carolinas and beyond, and the roar was made by a large school fiercely charging the ranks of a school of sardines, to capture which they sprang into the air, surged along the surface, all the while beating the water with their tails, creating a loud and peculiar sound called by my boatmen "beating" - a term which well applied. With lusty strokes, Chief now sent the dinghy flying ahead, and in a few moments forced her into the midst of the wildest and most remarkable commotion I had ever witnessed. The fishes had moved inshore, and for two or three acres changed the water into a foaming sea. They were in the air by hundreds, their silvery sides glistening in the sunlight, their fins flashing golden yellow - a most 
exhilarating spectacle. I had reeled in my line, but as I lifted it from the water a jack seized the bait, and broke it. As the bow of the dinghy ran up on to the sandy beach I saw scores of fishes, ranging from ten to twenty-five pounds, leap from the water out upon the shore. I sprang overboard knee-deep into the throng, and found that the sardines formed an almost solid mass two feet or more wide directly alongshore, with stragglers forming a dark streak for five feet out. Into this helpless cordon the jacks were plunging, maddened with excitement, long ago satiated, and now killing in wanton sport, for the mere lust of killing, filling the water with silvery bodies and their parts until a line of blood marked the mêlée.

The jacks paid no attention to us, and my Seminole boatman, himself seized with the desire to catch the fishes, carried away with the excitement of the scene, plunged his hands into the teeming mass and grasping the jacks by the tail tossed them upon the beach, where scores were leaping and beating their way down the sands into the water again. I was repeatedly nearly overthrown by being struck by them, and finally made my way to the beach to watch 


\section{The Jack}

this remarkable scene of carnage, to revel in which, gulls, pelicans, and man-of-war birds were now gathering from all over the reef. For ten or fifteen minutes the extraordinary spectacle was continued, until the low beach was lined with jacks, dead and dying; then the school drew off as suddenly as it had appeared, leaving the long, sinuous red stain to tell the story.

This, I learned, was the method of feeding most in vogue among jacks in this region. The school, composed of thousands, would sweep in from the gulf, follow up the narrow blue channels, the veins of the reef, and when a school of sardines was sighted, drive it bodily inshore, losing all sense of danger or fear in the wild excitement of the "beating." The remarkable leaps of the jacks, their quickness, evident strength, and agility, suggested a new field for the rod, nor was I disappointed. The school had left the lagoon, turned the point of the key, and was evidently now in the channel, where I found it the following day, and enjoyed sport that comes rarely in the experience of the angler, which even here could not always be counted upon, as the schools were constantly 
moving. Chief notified me that the jacks were in the channel, which ran so near the key that one could almost dive into the blue water. From the sandy beach I cast, having baited with a three-inch sardine, dropping the line, a number twelve, with its slender copper-wire leader, seventy or eighty feet from shore, then reeling quickly in. Hardly had the reel gained ten feet of the line when a jack shot along the surface taking it deftly, then rushed away throwing the water bravely, seemingly in search of others of the school; then it felt the line, and a reserve fifty feet went spinning off so rapidly that I was nearly forced into the water in my efforts to save something. I had not ten feet of line left on the reel when I stopped the rush of the valiant fish. No sulker he, but a constant fair fighter, a rush directly away, asking no favors, giving none; now up partly into the air with vigorous shake, now surging along the surface, to turn with a lateral rush, a very volley of tricks and stratagems hurled at the angler with a rapidity that could not fail to confuse the most phlegmatic veteran of the rod. The angler's poet, the late Isaac McLellan, writes :- 
"Swift speed crevallé over that watery plain, Swift over Indian River's broad expanse.

Swift where the ripples boil with finny hosts,

Bright glittering they glance;

And when the angler's spoon is over them cast,

How fierce, how vigorous the fight for life!

Now in the deeps they plunge, now leap in air

Till ends the unequal strife."

My light rod bent almost double and was tested in every fibre, as the long deep surges came thrilling up the line. Now my game had me fairly in the water, then I gained and backed up the sands, reeling when I could, giving, taking, drinking in the music of the reel, and anon catching a glimpse of the stolid countenance of the Indian boatman, who followed my every movement with amazement at the mysterious power of what seemed to him a whip, to control so powerful a fish. Gradually I worked the game up the beach into shallow water, that my sport might not be interrupted by the sharks, and for perhaps fifteen minutes played and was played and nearly outgeneralled by the fish; then waistdeep in the water, where it had forced me to save the delicate line, I finally reeled it within reach.

Every day in June, July, and August the roar 
of a jack beat could be heard, sometimes a dozen times from the reef, and so exciting was the incident that generally some one would pull off and join the gulls, pelicans, and other curious ones. At this time the fish would bite at anything. A handkerchief dashed through the water, a piece of coral thrown in, - indeed, any object would be seized; and I have seen several fishermen cast their lines into the throng, and become so excited that an inextricable tangle was the result.

The jack, like many other fishes, changes its name with the locality. On the reef where I caught it winter and summer, around Long, Sand, Bush, Garden, Loggerhead, and other keys, it was the jack pure and simple. On the Cuban coast it is toro. At Porto Rico it is jack, and jiguagua, but up the coast at Indian River it becomes cavally, while the South Carolinians call it horse crevalle. It ranges the waters of the Gulf of Mexico and vicinity, on the Pacific side of the isthmus, and is common in the region of Panama; but for some reason the fish does not range north on this coast, despite the warm water. In the Atlantic, specimens have been seen as far north as Cape Cod, but 
this is exceptional. The northern range of the fish, so far as the American angler is concerned, may be considered St. Augustine. I have fished for it unsuccessfully at Fernandina and from there alongshore as far south as New Smyrna, where it is caught. On the outer reef the jacks appeared in numbers and began the "beating" about the middle of April, sometimes a month earlier, the schools frequently being of large size. They apparently broke up into small bands and were caught until November in goodly numbers, the first norther ending what may be called the season, though some jacks were to be had every month in the year. They ranged in weight from ten to thirty pounds, but I am positive that I have seen jacks in a school off East Key which must have weighed much more. The smaller fishes, say of fifteen pounds, predominated. They spawned on the reef in June or July, nearly all fishes taken in May and April containing spawn, and a few weeks later young were found on the surface, every jellyfish being preëmpted by the young of some species

The best-known and the most available fishingground for the jack, or cavally, is from Cape Florida north on the West Florida coast, at 
Aransas Pass and other points on the Texan coast, and in the Indian River region. At the latter locality they afford excellent sport and can almost always be found from May to November, and few anglers in Florida but have tried conclusions with this fish. The jack is a convivial fellow, bold, daring, sociable, with a penchant for displaying its attractions around wharves and docks, darting along near the surface, a vision of silver, gold, and green, its " Roman nose," large head, and prominent eyes making it a conspicuous object, while the variety in size renders it game for the smallest rods. I have taken small jacks with a trout-rod with good results, and one can grade them up with rods adapted to their size, which is an essential in all fair fishing. In taking the large jacks I used a jointed greenheart rod eight and a half feet long, not over twelve ounces in weight; the reel held about three hundred feet of line corresponding to what is known as number twelve cuttyhunk; and for jacks weighing from ten to fifteen pounds, even a number nine line, providing three hundred feet was at hand, was sufficiently strong to enable me to land the game.

The jack is not an epicure; any lure is game 
for it. I have caught a fish trolling with a white rag, with crayfish, conch, cut to resemble a sardine, or mullet, and with a hand-line after a sail boat it affords all the sport of the bluefish when taken in the same manner; but for true sport the rod should be employed, casting or trolling with sardine or young mullet bait impaled on a $3 / 0$ O'Shaughnessy hook.

The jack, Caranx hippos, is a member of the family Carangida, a near relative of the mackerels and pompanoes; on the Atlantic coast alone there are twenty-five or more species, many of which afford prime sport with the rod. The only criticism one can make concerning it is that it is not a table fish of the first rank, though in the hands of an expert chef the dark meat is excellent. The hard-tailed jack, or jurel, Caranx pisquetus, though not attaining the size of the former, is of very similar habit and very gamy, its swift movements making its capture rare sport with a light rod. Once while turning green turtles on Loggerhead Key, a school of these fishes began to beat alongshore. I waded among them and threw out upon the sands as many as my men required by catching them by the tail, as they dashed into the almost solid mass of sardines. 
When seized they wriggled, or quivered, so convulsively that they imparted a series of seeming electric shocks felt as high as my elbows, and curiously enough some of the boatmen believed that this jack was an electric fish. I have noticed the same effect when holding a bonito firmly by the tail, and a dying tuna will sometimes impart a tremulous quivering motion to a small boat.

The jacks add greatly to the pleasure of anglers along the coast of Florida, especially in the Indian River country, down by Biscayne Bay and up the west coast, where they are easily caught, and at Aransas Pass, Texas, though I failed to take them at this interesting fishing ground. It is one of the highly esteemed game fishes; and at other localities in the Gulf states, its valiant habit commends itself to the man with the rod. 


\section{CHAPTER XII}

\section{THE CALIFORNIA SHEEPSHEAD}

"Out in the golden sunshine,

Throw we the net and line.

The silvery lines to-day

Flash in the silvery spray.

So throw the line, throw-yo, heave-ho!"

- Merivale. The Fisherman's Song.

THE region represented on the map by Southern California and its contiguous high seas is supposed by many to be a land of perennial summer, and to a certain extent this is true. The summer alongshore is a comfortable season, cooler than that of any Atlantic state; the winter a cooler summer, when the mercury drops into the roaring thirties and wild flowers insist upon coming into bloom. It is not a real winter, yet certain fishes, creatures of habit, insist upon their prerogative and make this floral, verdant winter an excuse for following the ancient and honored custom of their confrères in other and colder seas; in a word, they migrate. 
One could tell by the first glance at the sheepshead that it could not by any flight of the imagination be included in this class; that enormous white protruding under-jaw, the very archetype of determination and obstinacy, tells the story. The sheepshead remains winter and summer. True, it may move out a few fathoms in February or the preceding month, but it can be caught any day in the year from San Diego to Santa Barbara by boatmen who know the ways and haunts of fishes. In general appearance the adult sheepshead is one of the most remarkable of fishes, due to its enormous hump, or forehead, formed by a fleshy pad, which gives it a most pugnacious appearance, the fish resembling an animated battering-ram. The body is deep, the tail powerful, the pectoral fins ample; and in swimming the sheepshead uses them more than any fish that I recall except some of the kelp, and parrot-fishes. Its coloring is as remarkable as its shape. The head of the adult male, its dorsal and anal fins, the tail and the back part of the body are jet, often blue black resembling velvet, the remainder of the body brown, almost white or a deep crimson, the latter being the most prevailing color, indicating a perfect physical condition. In con- 


\section{The California Sbeepsbead}

finement I found that the rich crimson band faded in a few days.

The coloring of this remarkable fish is so arranged that it appears to have three large distinct bands; the head black, the mid-body crimson, the caudal portion black. In old males the underjaw becomes very prominent and is pure white. The fish has an enormous mouth, recalling that of the hogfish, which is armed with canine teeth so prominent that they give it a most ferocious appearance. The eye is small yet richly colored, and while lost in the enormous head, is an interesting organ giving character to the fish, due, perhaps, to its unusual power of motion. Thus a large sheepshead, which I kept in confinement, would follow me around as I walked by its tank, begging to be fed, poising and holding itself in position by delicate and dexterous motions of its side-fins. It would follow every movement with its eyes, tipping and turning about to an extraordinary extent. This fish became very tame, and with it I kept others of both sexes and all sizes, which were so varied in color and marking that they would be easily considered different fishes by those not familiar with them. The females were normally a dusky red or rose color all over; some 
almost white; the very young maroon barred with black.

Owing to this diversity of colors the fish is known by various names along the coast - the fathead, or redfish, being the most familiar; but at the islands, where it is taken with a rod as a game fish, it is known as the sheepshead, and to science as Pimelometopon pulcher (Ayres). The average fish ranges from ten to fifteen pounds, but I have seen large males which would weigh twenty or twenty-five pounds. The sheepshead spawns at the islands in June or July, depositing its eggs in the kelp beds near shore; and these ocean forests are its home, where, amid the most æsthetic surroundings, it poises in company with the colossal black sea-bass. The islands of Southern California and much of the mainland coast have this border of kelp, which is a fishes' highway, - a maze of vines (macrocystis) of enormous length, whose leaves, long, broad, and richly tinted in olive-green, rise from great depths and sway in the current, or at ebb tide lie along the surface, their fluted edges fluttering in the soft wind, often waving slightly above it.

This submarine forest is the salvation of the fishes. It forms an effective breakwater, without 
which many would be unable to live, owing to the surf, which would otherwise roll in strong and pitiless. On the South American coast the kelp attains a length of nearly four hundred feet, and without its protection it is easy to see that life on shore would be difficult to sustain. The kelp in rising upward forms halls, parterres, and colonnades through which the sun projects its rays, bringing out their many beauties, as each leaf is a study in itself, abounding in varied forms which constitute the food of certain fishes. White lacelike corallines cover them; crabs and shells, which mimic them in color, crawl along their stems, and delicate hydroids in many forms and shapes add to their beauties. The water is so deep along this highway of the sheepshead that blue water is seen through its interstices bringing out the leaves and stems in strong relief. In the watery atmosphere float countless living gems the Sapphirina-a minute crustacean, which vies with actual gems in its beauty. Some are like diamonds; others are yellow, blue, red, or crimson; and so rich and plentiful are they that, peering down, one might believe that some lavish Midas had sprinkled the water with jewels. Here float gorgeous jellyfishes, some with tentacles 
thirty feet or more long, tinted a deep lavender; others are crystal chalices, or chains of dainty design. If the scene along this forest is fascinating by day, what can be said at night, when myriads of lights appear. Every point and form then becomes a living light, while the water itself blazes out in silver radiance.

Such is the home of the sheepshead, the sly, cunning, jocular denizen of every ocean hedge and byway from San Diego and beyond to San Clemente, Santa Catalina, the islands of Santa Barbara on to Point Concepcion, which appears to be its northern limit. At the island of San Clemente it is particularly plentiful, the many caves lined with kelp affording it retreats to its choice. Looking down through the openings of the kelp, following some vagrant sunbeam, I have seen dozens of these poseurs and watched them, unsuspected. They were always deliberate in their movements, sailing in and out of the various halls formed by the kelp, accompanied by the dazzling golden angel-fish; now standing on their heads to pick up some object on the bottom, or darting down to rub themselves upon a mosscovered rock. I recall one huge fellow at this place which moved sedately about, proudly drag- 
ging three feet of what appeared to be a cod-line, the hook plainly visible against its white jaw.

At such localities the angler tarries to try conclusions with this doughty fish. The boat is anchored within the kelp, one of the leaves being hauled aboard as an anchor. The rods are taken out, put together, and the question of bait remains to be decided. When the fish is in the biting humor, sardines are readily taken, but when it is coy, crayfish, the long-whipped crustacean, which takes the place of the lobster in California and the tropics, is selected. But the sheepshead is no clumsy game, to be caught even on selected bait. At times it scorns anything; but it happens that to-day the fish is in the biting humor, and no sooner has the bait reached the bottom in twenty feet of water than it is taken. A good honest strike this. No nibbler to peck at the bait and examine it, like a customhouse officer, for hidden fish-hooks, but a strong, steady jerk to which you respond with as heavy a hand as the exigencies of the situation and the hard jaw of the fish require. There is no doubt as to the result; the fish is hooked, the water hisses before the line, the reel sings merrily, and the fight is on, with a royal foeman that tugs, rushes, plunges, 
hammers, and sulks, all in such rapid succession that the novice is fairly puzzled, recognizing the tokens of several fishes. With difficulty the fish is kept out of the kelp, but finally it rushes along the bottom, making for open water, and you have a clear field in which to play your strength against a very clever fish that shortly demonstrates its game qualities by taking the line in long and continued bursts of speed, which test rod, line, and the finesse of the angler, who wins only by careful work with the reel and thumb brake.

Finally, after having been repeatedly stopped, the fish begins to come in on the reel, fighting every step, taking long lateral runs to dash alongside with an impetuosity that so demoralizes your amateur gaffer that he misses, and so the fish has to be turned again. This time it is on the surface, its great bands of jet and red, its enormous head and white underjaw, making it an extraordinary object. It lies for a moment flapping its big pectorals and rolling its comical redrimmed eyes at you out of a sea of black - an appeal for mercy that is sometimes heeded by certain anglers who flatter themselves that they understand the language of fishes. Fishing in 
this manner on the west side of Santa Catalina and at San Clemente, I have known these fishes to bite so rapidly that they took the bait as soon as it reached the bottom. It would have been a piscatorial bonanza for a professional fisherman, as he could literally have filled his boat with sheepshead of the largest size. So much for taking this fish with a light rod where it has a fighting chance. If the fisherman really enjoys hand-line fishing, it can be had all alongshore.

The sheepshead is a valuable food-fish in California, many thousand pounds being dried or salted annually; but for domestic consumption it would be classed as a "chowder " fish, and is excellent for the purpose. While its praises probably have never been sung before, I commend it to the angler, confident that when taken with a fairly light bending rod and a number fifteen or eighteen cuttyhunk line it will repay the expert in the gentle art of angling.

With the sheepshead, living in its highway, is another gamy fish, the whitefish, Caulolatilus princeps (Jenyns), which attains a maximum weight of twenty pounds, that has afforded me such sport that I may refer to it. Small or medium-sized specimens may be caught almost 
anywhere alongshore, away from sandy beaches, and at rocky points, but the largest I have found after fishing at nearly all the islands were at the government island of San Clemente, about fifty miles from San Pedro, or opposite San Juan Capistrano. During a yachting trip around this island we anchored on the lee or east side where there was a rapid current, and in this I amused myself one morning casting for yellowtails. Instead of the latter, quantities of whitefish rose and began to follow the bait. At a distance they resembled and acted not unlike pollock, and taking a ten-ounce split bamboo rod, and using crayfish (spiny lobster) bait, I was soon participating in sport well worthy the name. The swift current carried the bait astern, and as it drifted twenty-five or thirty feet there was a struggle for it by scores of whitefish of large size, their attractive drab colors, with dashes of blue and yellow, flashing in the sunlight as they played upon the surface. When hooked they rushed away with force and vigor that tested the light tackle to its utmost, and as the sport grew fast and furious, and several anglers joined, the snapping of the delicate lines began. Some. of the largest fish made a determined battle, and an old 
trout fisherman of the party remarked that they equalled in game qualities any of these fishes he had ever taken. Ten or more minutes would be occupied in landing a fish, and with trout tackle it would have taken a much longer time to bring the largest to gaff or net.

The whitefish is one of the most valuable of the California food-fishes, and one of the most attractive, in its demure coat of gray, drab, or olive. It is not a migrant, being found about the islands from the Coronados north at all times. The attention paid to angling in Southern California is well illustrated at certain points, as Coronado Beach, Long Beach, Terminal, and Santa Monica, where long piers have been built out into the surf, upon which anglers who are satisfied with small fry can indulge in the pastime. Here the mackerel, halibut, and various kinds of surf fishes, Embiotocida, are taken, which, if it were possible to fish for with trout-rods, would afford fine sport, as the fish weigh from one to five or six pounds, and are gamy; but the exigencies of the case require stiff rods, and the long bamboo pole is chiefly used, as by it the fish can be lifted to the high piers. Large fish, if hooked, are led ashore and hauled upon the beach. The 
"surf" of these localities is particularly interesting from the fact that the young are born alive. I have kept the parents of the species known as shiners, Abeona minima, in a tank, where the young were born. The latter immediately "schooled," and formed interesting pets. They fed from my hand with avidity, displaying no fear, - the entire school following me as I moved around the tank, watching every movement with lively interest. The young were an inch and a quarter in length at birth, and were at once able to care for themselves, the parents paying no attention to them. As their name suggests, they are found in the surf, feeding upon the various crustaceans which burrow in the sand.

A gamy fish, for a black-bass rod and the lightest line, is the rock-bass and its many species of California waters. I have taken them up to ten pounds and found them gamy; but light tackle is a desideratum, as while they are modelled after the shape of the black bass they have not the staying qualities of this fish. There are many species, all found at rocky points, lying in the weed simulating more or less the general tone of the bottom. 


\section{CHAPTER XIII}

THE CHANNEL-BASS

"The blessing of St. Peter's, master, be upon all that hate contentions, and love quietnesse, and virtue, and go a-angling." -IzaAk WaLton.

INNES - RANDOLPH has described the channelbass or red-drum in verse:-

"Long as a salmon, if not so stout, And springy and swift as a mountain trout."

Any one who has taken the fish will recognize the faithfulness of the picture. The poet is too modest; the fish is often longer than a salmon, and far more active than a trout. In truth, the marine fishes have so long been caught with heavy hand-lines that their true game qualities have never been fully appreciated. Let the troutfly fisherman take a bonito of six pounds with the rod with which a six-pound trout has been successfully landed, or attempt to catch a seventeenpound yellowtail or kingfish with the correctly appointed salmon rod, which has taken salmon of similar weight, and the relative qualities of the 
two will at once be apparent. To land a twentypound yellowtail with a long salmon rod would be a matter of hours, at least such was the opinion confided to me by an old fisherman after a day's yellowtail fishing in California. Laymen are prone to scoff at the technical names of fishes. They care little that the channel-bass is of the genus Scianops, and that it is known among all nations as Scianops ocellatus, the latter term referring to the spots near the tail. The actual necessity of this common language name is emphasized in this fish, which has so many titles, local names from Virginia to Texas, that the would-be historian of the fish is amazed, and the travelling angler more so. Where I caught the fish at the mouth of the James River, the dug-out fishermen, who cruised around the oyster beds in their rakish crafts, called the fish the drum, and I at first supposed they meant the big drum, the bass drummer of the finny tribe.

At the mouth of the St. Marys, Georgia, my boatman, who was a city father of a neighboring commonwealth, took me "red-bass" fishing. The boy who collected fiddlers for me in the swamp on the way to Fort Marion, Florida, confided to me the best "spotted-bass" fishing-ground in the 


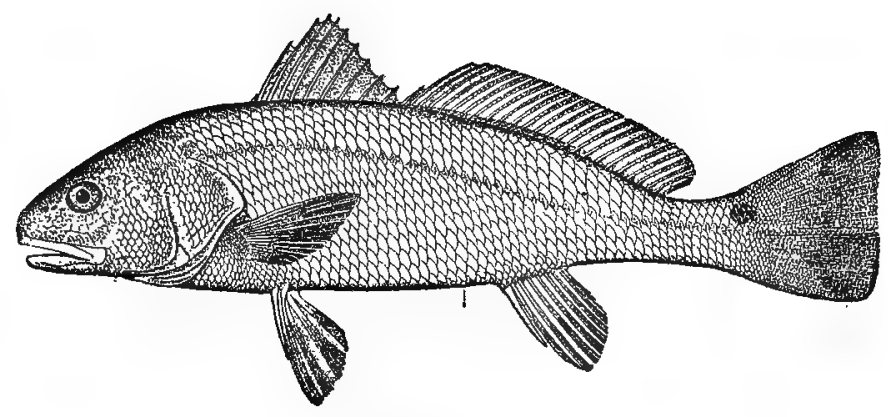

RED DRUM ; REDFISH; "CHANNEL-BASS" Scicenops ocellatus (Linnæus)

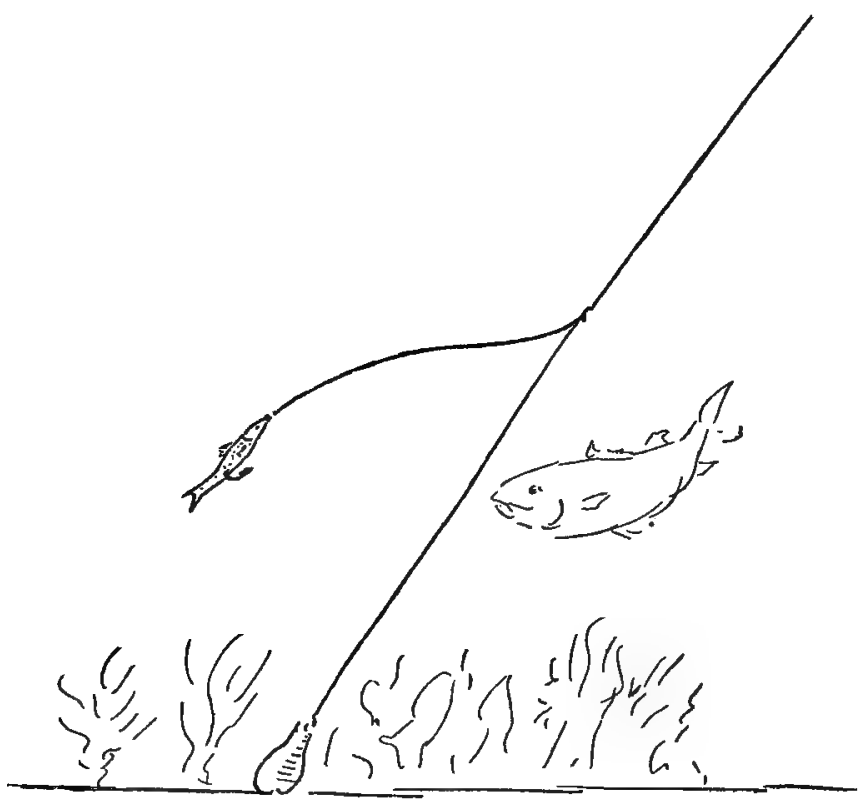

Rig for Grouper, Red Snapper, etc. ; fishing-hook above the sinker 

vicinity. When I reached the St. Johns and cast my luck among the genial pilots of Pilottown and the shadmen of Mayport, I was told that in the mouth of the river I would find the finest channelbass fishing in America. This was bewildering, but the end was not, as on a trip to Jacksonville I met an old friend, $\mathrm{N} \longrightarrow$, who had advised me by all means to take a run down through the Indian River country to catch "red-horse." Another friend who lived at Tampa invited me to go over and try the "reef-bass." While talking over the fishing outlook with an angler in New Orleans, he asked why I did not take a run to the coast and try the Poisson rouge; while at San Antonio, Texas, I was regaled with stories of the big Pez Colorado to be had down at Aransas Pass and all alongshore. What a diversity, what a plethora, of sport these titles open up to the mental vision of the insatiate angler! Yet everywhere I found the same fish was meant; namely, Scicenops ocellatus. It will come to this:-

\section{Scene, Indian River. Anglers Passing}

First Angler. What luck ?

Second Angler (a better fisherman than grammarian). Fine. Ten Scianops ocellatus.

[Boatman faints. 
The question what to term this fish may be argued elsewhere. I am going to call it the channel-bass, first, because this name appears not to be applied to other fish, and secondly, I have noticed that the majority of anglers and sportsmen prefer and use the term, which is the very best of reasons. In casting over in my mind the best channel-bass fishing I have enjoyed, the St. Marys and the mouth of the St. Johns rivers and the beach out from Pilottown, Florida, crowd and elbow to the front. The mouth of the river is an interesting place, especially at Mayport, where the sand-dunes at the time of my last visit were migrating, and one fisherman's house was almost completely covered. In the morning the housewives would be seen sweeping out the sand from the walk as they would snow. Some of the buildings were on stilts, and it was almost necessary to take a running jump to reach the door of one hostlery. The boatmen, Americans and some Minorcans, and their descendants, were nearly all in the shad business, and many fished the mouth of the river habitually. The water over the har was often very shallow, so that schooners laden with lumber were sometimes obliged to wait for a combination of high tides 




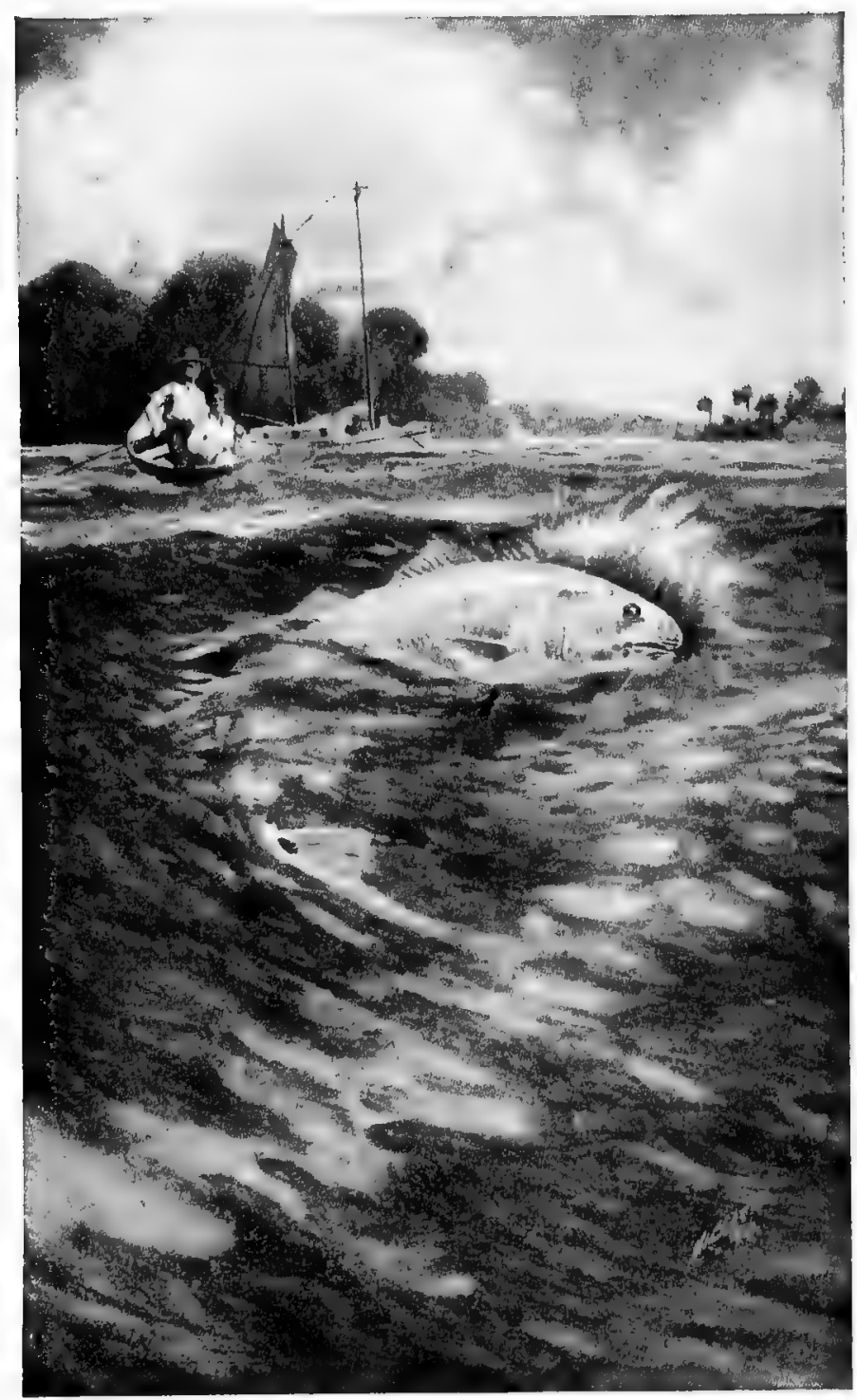



and an east wind to blow the water in and up; so shallow was it at low tide that I saw a gigantic sunfish ground as it wandered in, its struggles attracting so much attention that it was ultimately caught. This shallow water created a heavy sea, or rip, which was more or less uncomfortable at times; but by anchoring on the edge of the channel, and fishing at the slack tide, much sport was enjoyed, while, up the river, in smooth water, there was an excellent "channel-bass ground," very popular with the anglers who came through from Fernandina in boats or from up the river. So fierce was the tide that almost every one used hand-lines and sinkers, and even then the latter would often apparently rise to the surface; but at slack water I fished with my rod, which was about eight feet long, of greenheart, weighing twenty-four ounces; the line, a number twelve cuttyhunk, tested to pull twenty-two pounds, and hook about the size of a 7/0 Limerick, though the boatmen used something much larger. The bait was mullet and crab.

We started in at the ebb, and anchored in a place selected. In a short time the tide, rushing against the incoming sea, created a singular rip, unpleasant to look upon, which seemed to merge 
into a heavy-breaking sea farther out. We picked up a few small bass by casting up-stream, using pipe-sinkers, but in a marvellously short space of time the bait and sinker would pass the boat and lie at the surface. Several sharks followed up the mullet trail and afforded some sport. The shad fisherman, who had never seen a five-foot shark killed with a line of that size, confidentially informed me that "he'd have been dogged ef he'd 'a' b'l'eved it, ef he hadn't seen it."

Gradually the current slackened, and then suddenly my reel gave tongue, and in a few seconds I was engaged in sport that was sufficiently exciting to satisfy the most exacting angler. Out into the midstream the fish went in a splendid run, having all its own way, the tackle being too light for any immediate protest, and it was two hundred feet distant before the thumb brake began its deadly work and I turned it. Then it shot across the water in the opposite direction, never slacking or giving up. Now the reel would gain twenty or thirty feet, and the gamy fish would spring forward and turn downward, sounding with an impetuosity, that was irresistible, making everything hum with the soul-stirring zip-zip-zip! of the reel, which so truly echoes the exact movement of the stricken 
fish. The gamy creature would have joined forces with the current and towed us out to sea but for the strenuous efforts of the boatman; and so, ever fighting, making a brave show of resistance, the fish came in, cutting the water with splendid side rushes, growing shorter and shorter until I had it on the quarter, its burnished sides flashing in the sunlight, and as it turned and lay upon the surface, I saw why some call it the reddrum, as a red golden iridescence caught my eye as though for a second the fish had blushed. I passed it forward to the mercies of the gaffer, who, with a clean-cut lift landed and held it up for my inspection. It was a most attractive fish, weighing between thirty and thirty-five pounds, which had engaged our attention - a minute per pound, according to the boatman.

The channel-bass bears a strong resemblance to the California roncador. The body is long and well proportioned; the back perfectly arched from the tip of the nose to the base of the tail; the nose blunt, mouth opening parallel to the ventral line or bottom of the fish. The head is long; eye small; dorsal fins low, the second dorsal being long and beautiful. The tail explains the gamy nature of the bass, being a large and 
powerful organ. The color of the fish is pronounced bronze above, silver and grayish below; over all a reddish iridescence, caught when the fish is seen at an angle, making it a resplendent creature immediately after the catch. At the base of the tail is a single black spot, about as large as the eye. On some fishes there were several of them, and I noticed that some of the negroes called the fish "two eye" for this reason.

In the South the St. Johns is one of the best localities for channel-bass, though I have had excellent sport at Fernandina near Fort Marion. It is found in the deeper portions of the channel, and I took large specimens later from the beach on the Pilottown side, where the water is deep near shore. This locality was equally famous for large sharks, strikes from this game being about two to one of channel-bass. One hooked with a heavy shark line, which I had made fast to a heavy log, carried the latter down the beach and nearly dragged me into deep water, a lucky chance changing the programme. In a word, sharks are to be expected here. On the St. Johns the channel-bass appears with some regularity in June, and in this month, and in July, the angler may expect large specimens running up to fifty 
or sixty pounds, - the fish attaining, if current report can be relied upon, seventy-five or eighty pounds. The largest I have seen weighed sixty pounds. In August and September, in the St. Johns, the fishermen expect a second run of smaller fish; and the sport is good until November. Anglers are told that they can be caught later. Possibly individuals have been, but I have religiously fished the mouth of the river in January and did not take a channel-bass. My boatman insisted that they were there, and intimated that they had been taken, so I concluded that while luck was with me in the summer I was a poor off-season fisherman. The average-sized fish taken in the rivers of Florida is from twentyfive to thirty pounds, and there is a remarkable difference in size and tastes in different localities. I tried several "spinners" in the mouth of the St. Marys, but did not have a strike; yet on the Indian River I understand, on the excellent authority of Dr. Kenworthy, the dean of the angling fraternity of the South, that this method has been very successful. I have seen a yellowtail hooked with a tooth-brush handle metamorphosed into a jig; yet this fish refuses a spinner. There is no accounting for tastes even among fishes. 
Surf fishing for channel-bass is an exciting sport. One morning in riding down the long and beautiful beach of Amelia Island, Florida, which was seemingly covered with snipe and plover which rose into the air in silvery clouds as I galloped along, I came upon a group of anglers who had a tent in the brush and were fishing for channel-bass. The wind was offshore, the surf low at the point they had selected, and they waded out from shore at low tide, and with heavy cast-lines and sinker tossed their bait far out into what appeared to be a school of channel-bass, which made so gamy a struggle that more than once two men seized a line and with shouts of victory ran plunging over the waves up the sands. Doubtless the heavy normal surf here would not permit it, but if an iron pier could be run out over the breakers, the rod fisherman would have some remarkable sport. The admirer of this fish will find it almost everywhere along the Indian River, but I never saw it on the reef in the vicinity of Key West, or farther west. It is reported as abundant on the west coast of Florida and in the Gulf states. Mr. Silas Stearns states that they appear in this locality in March and April. They seem to congregate about the mouth of 
inlets at this time, sometimes going in at once, again hovering around outside. They come in large schools which soon break up. In October and November they leave. Following around the Gulf, we come to what is probably the greatest fishing-ground for channel-bass in this country the region around Galveston and Aransas Pass. Here the fish is omnipresent, the best fishing being from May to November. This section of the country is comparatively little known to the angling fraternity, but abounds in large numbers of game fish of many kinds, channel-bass being large and gamy and the common fish of the country.

I fished for them here in the inner bay of Aransas in shallow water, the bass congregating in the shallow holes, taking shrimp bait with avidity. Another excellent location was on the Gulf side of the island, where one could wade out and cast for bass in the surf with a light black-bass rod. I had good sport with small ones up to ten pounds. It is not necessary to go to Florida or Texas for fine channel-bass fishing. In South Barnegat Bay, at Harvey Cedars, some of the finest fishing can be had at times, especially in September, - the fish running large, 
catches ranging from fifteen to fifty pounds. The luck of Harvey Cedars is a trite saying among the anglers who know it well, and the fine fishes taken here illustrate the singular fact that there are many famous fishing resorts along the Atlantic coast near New York for some reason not so well known as far inferior places many miles distant.

As game, the channel-bass recalls the striped bass. It lives upon crustaceans, mollusks, and sea-worms, and has been seen to root and tear up the weeds in shallow water in its search for food. This explains its presence along the line of surf in the shallow waters of the great sandy beaches of the coast, the home of numerous burrowing crustaceans. While an oceanic fish, it enters rivers, being caught as far from the sea as Jacksonville in the St. Johns, and according to Dr. C. J. Kenworthy, in Crescent Lake and Lake George, Florida, where large fish are taken with a spinner. As to their spawning habits, Mr. S. C. Clark states that the channelbass spawn in the Indian River, Florida, in August and September, the young fish being found there at all times. The adults appear at the inlets of Florida in January and Feb- 
ruary, and remain until August, spawning there in the shallow bays, leaving or going to sea in October. Dr. Jordan reports young measuring two and a half inches at Pensacola in April. This gives the Indian River region a channelbass season, of nine or ten months, about equivalent to that of the yellowtail of the Pacific.

As a food-fish the channel-bass is of great value, those up to ten or fifteen pounds being of excellent quality, the older and larger fish better adapted to the angler, though I have eaten a large channel-bass, seined on the St. Johns, that was beyond criticism. The economic value of the channel-bass can be realized by a glance at the catch and returns of various states. In North Carolina, in I 888, I 40,000 lbs. were taken, valued at $\$ 3800$. South Carolina took out $50,000 \mathrm{lbs}$., valued at $\$ \mathrm{I} 600$ in the same time. Georgia, 20,085 lbs., valued at $\$ 470$. Florida, 404,557 lbs., valued at \$II,000. Mississippi, I 40,000 lbs., valued at $\$ 6000$, and Texas, 838 ,000 lbs., valued at $\$ 32,76 \mathrm{r}$. From this it will be seen that Texas, where the fish is known as redfish, is the headquarters for channel-bass and offers an interesting and profitable field for the angler. 


\section{CHAPTER XIV}

\section{THE ALBACORE}

"Vext with the puny foe, the tunnies leap,

Flounce in the stream, and toss the mantling deep;

Ride over the foamy seas, with torture rave,

Bound into the air and dash the smoking wave."

- OpPian.

THE albacore, the long-finned, big-eyed harlequin of the Santa Catalina and San Clemente channels, is the understudy of the tuna, following its mighty cousin, cheek by jowl, in many of its cyclonic rushes into the bays and harbors of the California islands. Owing to this habit, it is often a factor to be counted on in tuna fishing. Being more active and agile, it seizes the bait intended for the tuna, and the unfortunate angler, while surrounded by the big fish of his choice, catches nothing but twenty-fivepound albacores, which, while excellent sport, under the peculiar conditions becomes a deepseated injury. 
In watching a school of tunas at this time, the albacores are seen, types of activity, rushing hither and yon, in marked contrast to the larger fish, on the alert to steal the prey of the tuna or pick up the silvery morsels which often besprinkle the water after the larger fish has rushed through a school of smelt or mackerel. Like the tuna, the albacore is a pelagic fish, born on the high ocean and a rover in many seas, at home in mid-ocean, coming into shallow water and near island shores in spring to exercise its voracious appetite upon the small fry of its choice-herring, anchovies, squid, smelt, mackerel, and others.

So far as known the Southern California islands are the only localities where the albacores are caught with the rod; the conditions being particularly favorable, the fish coming in near the rocky shores from the Coronados to San Miguel Island where there is smooth water in the lee, permitting the angler to play them with pleasure and comfort. I have hooked the albacore within twenty feet of the rocks, but the favorite and most popular trolling-ground is half a mile off Avalon Bay, where large schools, or many small ones, are found, breaking the mirror-like water 
into foam, from May fifteenth to November or December, the fall fishing possibly being the best. At any time, but especially in the morning, the swift launches of the boatmen, with their gay tuna and other signals stretched to the breeze, may be seen in the offing, the two anglers sitting in the stern with rods out on either side.

A typical equipment may be described as follows : the rod of greenheart, noibwood, or split bamboo; if the two former, to weigh about twenty-six ounces, as the fish is often a sulker and has to be "pumped." The rod, if the angler consults his greatest convenience, is a single piece ; that is, a long tip with a short butt, and there are two long tips to such a rod, or better still, three - one stiff, for tuna, a second less so for albacore, and a third lighter yet, for yellowtail and whitesea bass. The rod has double bell guides of German silver that the line can be changed every day so that the rod will not assume a chronic curve in any given direction. The reel, which should always be lashed upon the rod, should be of medium size, to hold three hundred feet of wet number fifteen cuttyhunk line, which is tested to twenty-eight pounds, though some anglers use tuna reels and tackle for this sport, owing to the 
possibility of hooking one of these fishes at any time. A short phosphor-bronzed leader and an 8/o O'Shaughnessy, a Van Vleck; or any similar hook completes the equipment. Trolling at full speed the albacore can be taken with a bone jig, but there is no pleasure in this for the rod angler, as before the engine can be reversed the fish takes nearly all the line. Sardine, smelt, or squid are typical baits, but the latter is almost impossible to obtain, and smelt is the common lure. The hook is inserted in the mouth, brought out at the gills, the point turned and thrust into the belly of the bait near the vent; when pulled straight, or "set," it is almost concealed. The mouth of the smelt is closed with a wire fastened to the shank of the hook, or thread may be used, and the lure is complete. No sinker is employed, and each leader or snell should have two, if not three, swivels.

We are now ready for the sport. The launch is sent slowly along, the speed being governed by the exigencies of the occasion. The boatman and gaffer sees the schools from afar, as the albacores leap from the water two or three feet, and follows them up. The strike comes, - a long, sudden, tremendous strain or jerk, which has 
been known to take the rod from the hands of a not over-alert angler. There is little need to strike or attempt to hook the fish; in nine cases out of ten this is accomplished by the albacore itself, as it strikes on the run, with a fierce rush, and does not stop, bearing away and down as it feels the hook, with such irresistible force that the angler is often obliged to give and give, until his thumb loses nearly all sensation by the continual pressure upon the leather brake in the vain attempt to stop the fish, which plunges deep and yet deeper, sounding at times like a very whale; then, perhaps maddened by the reel, it sways and cuts the water to right or left and rises far away in so singular a manner that the angler fears that it is being chased by a shark, and so, ever fighting, ever bearing off with tremendous power for its size, the fish comes slowly in, the angler with the butt of the rod in the leather cap between his knees working his passage and paying fare as well. The multiplier is all-powerful, and far down in the azure waters a flash of silver is seen, circling broadside on. Slowly it rises, now showing a black eye almost as large as that of a plesiosaurus in its adolescence. At this stage it is well to count on a stupendous rush, as the 
silvery game, at the apparition of the boat, makes one of a series of final charges, any one of which might shatter the rod, or break the line if it was checked. The click gives tongue loudly with its short, quick ze-e-eing, "stabs the air with its shrill alarm," and again the reel moves and the fish comes in. This is repeated several times during the fifteen or twenty minutes' contest, and presently the angler sees the game at the surface, still full of fight, a finny fury. Bending the tip forward he passes it into the field of the gaffer, who ends the game by his clever movement beneath its silvery throat.

The strength of the albacore can be appreciated by the terrific tattoo which it now plays upon the canvas-covered planking of the boat, which, if small, it shakes from stem to stern. The boatman gives the fish its quietus and holds it up by the measuring scales, with his "Twentyfive pounds, sir!" And this is what we see: a plump, compact tuna, all but the long side or pectoral fins; about three feet in length, the muzzle sharper, the eyes larger, almost the same spikelike second dorsal and anal; a remarkable thickness and compactness in proportion to its length, and one would invariably "guess" under 
its actual weight; the tail is strongly forked, keeled, and here are the finlets of the tuna, seven or eight in number. Trim the side fins, and the average observer not skilled in fish lore would announce it a tuna ; but these remarkable fins distinguish it from all other fishes. Each pectoral fin is nearly half the length of the entire body, or to be exact, two-fifths its length, shaped like daggers, with a slight curve downward; the fins are very narrow and in every instance observed by me were held close to the sides of the fish when swimming, the real locomotive organ being the tail, a "screw" of tremendous power. Doubtless the long pectorals have more to do with the remarkable agility of the fish than is suspected. In its coloring the albacore is very attractive, garbed in resplendent tints. Its back is a vivid steely blue, and being broad and rotund it is a conspicuous object in the water. The belly is white, or silvery, the fins dark, gleaming with a blue iridescence or lustre.

Such is the catch, the albacore, the Germo alalunga (Gmelin) of science, the most active of all its congeners. It is one of the commonest fishes in the Pacific waters, found in nearly all tropical seas, but not caught on the Atlantic 
coast and rarely seen. In the Mediterranean Sea it is a familiar catch in nets. Germon is its French title, but the common name, albacore, was given it by the Portuguese, who undoubtedly took it from the Arabic al, a; bacora, little pig. The specific name, alalunga, by which it is known in Sardinia, means "long-winged." Many authorities give the maximum weight of the albacore as twelve or fifteen pounds, which is far too low. I have measured an individual which weighed sixty-two and a half pounds, and have been informed by reliable fishermen that they have taken albacores in the deep San Clemente channel, ten miles west of Santa Catalina, which weighed one hundred pounds; but these large fishes rarely come inshore. The one first referred to was caught by an acquaintance, not fifty feet from the rocks, and for three hours it fought, towing the boat during that period an estimated five miles, often against the oars of the boatman, and making such strenuous resistance that it was considered a tuna until the long sabrelike fins of the fish told the story. No tuna could have made a better struggle than this long-finned, big-eyed wanderer of the family Scombrida.

On the Pacific coast the albacore spawns in 
July and August; at least at this time fishes with ripe spawn are observed. The eggs are deposited presumably in the open channel; the very young fish I have never seen. The smallest observed weighed about five pounds. The young resemble the adult, except that the pecto-. ral fins are shorter. The adult fish, while it is caught near the island shores, never approaches the mainland, being found from two to five miles out. Always present in vast numbers, feeding or playing, the albacore is a feature of the angling life of the islands and affords no little amusement to visitors who watch its leaps, and the turmoil it creates; now here, now there, ever wandering, it is a constant menace to the small fishes. The average catch weighs from fifteen to twenty pounds, yet fishes of this size drive the large flying-fishes inshore and often afford remarkable exhibitions of ground and lofty tumbling, almost invariably coming down like arrows. The rush of a school of albacores, as they charge the flyingfishes, invariably arouses the angling community, as every one knows that here are bonitos, and possibly tunas, all forming a pack of sea-hounds crazed with the lust for slaughter.

"Ahoy!" comes from a launch over the water, 
and a boatman, with a camaraderie not always found where competition is keen, is seen pointing away to the south, where a scene is staged on the blue, glasslike sea well calculated to stir the blood in the veins of the most phlegmatic angler. A great patch of the ocean appears to be in violent commotion; the air is filled with flying-fishes, which dart along soaring, not flying, crossing each other's path, resembling great dragon-flies, glistening in the sunlight, while a roar like the sound of distant waves breaking upon the rocks is heard. Boats are turned in that direction, and anglers, rod in hand, are presently in the midst of the fray. In such a sortie it is not a question of catching fish, but how many will satisfy. Two anglers have taken forty or more with rods in a few hours.

The greatest demand for albacores comes from the black sea-bass anglers, who have discovered that this leviathan looks favorably upon the rich oily meat of the albacore. To the dwellers on the Mediterranean it is a choice dish, but to the average American albacore is neither

"fish, flesh, nor good red herring."

Despite this, the offshore commercial catch is large and important in all the seashore towns 
from San Diego to Santa Cruz. As sport it brings many dollars to the coffers of the boatmen, who go from five to seven miles out from San Diego, Coronado, San Pedro, Long Beach, Redondo, Santa Barbara, and all alongshore. The catch for 1895 , taking this year as an example, was one hundred and seventy-eight thousand one hundred and forty-five pounds, valued at $\$ 4600$. Nearly all the fish used in this way are caught by sail-boats, whose owners troll far from shore in rough water, using several lines, and bone jigs. 


\section{CHAPTER XV}

\section{THE GROUPERS}

"You strange, astonished-looking, angle-faced, Dreary-mouthed, gaping wretches of the sea, Gulping salt water everlastingly, Cold-blooded, though with red your blood be graced, And mute, though dwellers in the roaring waste."

- Leigh Hunt. The Man to the Fish.

IN visiting different fishing-grounds, hunting for new fields to conquer in the sea, or alongshore, the sea angler instinctively contrasts or compares the various fishes he catches with those of other regions which he has known, and frequently finds many points of resemblance. The bluefish is represented on the Pacific coast by the yellowtail, the latter completely filling its place to the sportsman but not to the epicure. In Florida, where the cod is not found, it has a representative in a number of serranoid fishes, the groupers, which as food-fishes are almost equal to, and as sport rank much higher than, the cod. 
The angler who visits the outer Florida reef and wanders from Biscayne Bay down the islands as far as Loggerhead will find at Key West and all alongshore smacks fitted with wells which are often filled with groupers, principally the red grouper, caught in fairly deep water. When the well is full, the smack squares away for Havana, where the catch is disposed of to the Cubans. The red grouper is a large ungainly fish, ranging up to seventy pounds in weight, this being the largest fish of the kind I have seen, its length being about three and a half feet. It is an omnivorous biter, living near the bottom, in water from twenty to one hundred feet deep, preferring the bases of the great coral reefs, where an abundant supply of food is assured. As a hand-line fish at such localities, it affords some sport. The grounds north of Sand, Middle, and East keys of the Tortugas group may always be counted upon, winter and summer, while other fishing-grounds are common all over the Gulf, the fish having a wide range, from Rio Janeiro to Maryland, individuals wandering still farther north. The tackle used is a stout cod-line; the hook (I used a ro/o Kirby Limerick) is gauged a foot or more above the sinker, the theory being that the latter 
may sink into the branch coral or a grove of gorgonias, while the hook or bait would in this way swing clear. Again, the strike, or bite, is felt much quicker when the hook is above the sinker. The bait most in vogue at this particular point is crayfish or conch, the latter being hard and almost indestructible; at other places fish bait is employed.

If the right ground is found, excellent sport may be enjoyed, the red grouper being the chief attraction; but the pleasure is intensified by the remarkable variety of fishes taken, of which the big porcupine-fish, which fills itself with air when reaching the surface and sails along on the water like a balloon, is not least. The red grouper when at forty or fifty pounds is, so far as its game qualities are concerned, like the cod, there being more than a suspicion of laziness, though some big fellows will give fair play; but the fish should not be wholly condemned. Hauling the best of fishes from a great depth is not the most exciting of pastimes, but such fishes, given other conditions, often prove worthy the term "game." So with the red grouper; I found that while a deep-water fish, a companion of the red snapper and a bottom lover, it came inshore in June to 
spawn and at certain places could be found and fished for from the reef. Such a locality was at Bush Key in the Tortugas group, where I caught red groupers weighing thirty pounds with a rod in twenty feet of water. They could not sulk, and the rushes away and around the boat made me a convert to the despised grouper if found under the conditions described. The fish spawns in May and June on the reef, but as I often found spawn in specimens taken miles offshore in deep water, I assumed that this is not a rule with all groupers. Probably those near the shore move in to spawn, while those living in deep water, away from land, spawn in deep water; in other words, I should not consider the fish a migratory one. I frequently caught small individuals two or three inches in length, with fly-hooks and crayfish bait, around the mangrove roots in the lagoon, where they consorted with young grunts, gray snappers, and angel-fishes. As a table fish, when properly cooked, the red grouper is unexcelled in the South. Boiled, served with shrimp or crayfish sauce, is a very acceptable method of serving.

The red grouper, Epinephelus morio, belongs to the family Serranida, which includes many of 


\section{The Groupers}

the most valuable food and game fishes, many of which are noted for their size. It has a large head, with wide buckler-like gill-covers, very large or deep where its neck should be, grading off gradually; not what would be termed a handsome or comely fish, yet with its red coat, bright and prominent eyes, long and full dorsal, it makes a brave showing. The young, especially when they weigh about ten pounds, are particularly attractive.

There are fascinations in angling in tropical seas not experienced elsewhere. The fishing is excellent all the year round. Sir Henry Wotton, the good friend of Izaak Walton, once said that "he would rather live five Mays than forty Decembers," and every angler will agree with him, as where is there good fishing in December? It is the season in the North for story-telling. The angler takes out his rods, his fly-book, or his trolling lure, large and small, and tells to some patient and loyal friend, who has heard the same tale fifty times, of the colossus that escaped on a certain day; and the friend, with the camaraderie of the true angler, smiles, expresses wonder, and enjoys it, and fails to note how the monster grows with passing seasons. But there is a 
region where every month is May, where life is a constant angling fiesta.

"A heavenly Paradise is that place,"

far down on the outer reef. Any day in the year I could row out beyond the lagoon, watch my chance, and run through the narrow five-foot channel that breaks the great barrier, and float over groves of coral and gorgonias whose grace and beauty defied description. Mounds of olivegreen coral, patches of lavender and gold gorgonias fanned by the current, with their reticulated surfaces, some like ostrich plumes in red or brown; seaweeds of varied hues, delicate vines, living cloths of green covering the dead coral rocks, all forming the home of scores of fishes, any one of which was game to the not too critical angler.

It was over such a region that I met another member of this family. I had been fishing for the captivating yellowtail, and was reeling in, when there came a swirl of waters, a vision of a mighty fish, and my yellowtail line and tip were gone. I could see that it was not a shark. Chief, the boatman, expressed the opinion that it was a jewfish; but the robber was blacker, trimmer, 
swifter than the huge jewfish, so I baited a suitable line with a living yellowtail and cast it over into one of the "gulfs enchanted" which I could plainly see. The bait was very active, and made a brave showing with its vivid gold and silver tints, and as it sank slowly, struggling, something like a great shadow came out of the depths, and the next instant I was dragged down flat into the stern, and the line was hissing, leaping over the rail like a living thing. So fierce was the rush, so vigorous the onslaught, that for a few seconds I lost the line, and when I did grasp it, Chief had cast off the buoyed anchor and we were away behind as lively a steed as one would wish.

"Man-eater shark, sa'," grunted the Seminole, sententiously, but he had not seen it. I had, and it was either a jewfish or some fish new in my experience.

But no jewfish ever looked so dark and black as did this mystery that turned and towed us directly out to sea. And as the water deepened rapidly, we were shortly off bottom with the fish directly beneath us, towing the clinker-built boat so swiftly that she had not one, but two bones in her teeth. It was only after much exertion 
that I lifted the fish to within twenty feet of the surface; then it turned and towed us directly in toward the reef, where a high sea was breaking. Chief now took the oars and pulled against the fish, while I labored strenuously, gaining a foot or two, then lying back and holding hard, while the fish made desperate rushes, displaying an indomitable spirit, making me suspicious that I had caught a tartar. From early youth having had a penchant for taking impossible fishes in various ways, it had often occurred to me that anglers were strange creatures, undergoing great fatigue, working, straining, being jerked this way and that, to conquer a big fish. Under the banner of sport, this was pleasure; but if one was rewarded like the ordinary daily fisherman, how prosaic, how monotonous, how hard the labor would be. It all depends upon the point of view, and as I controlled my fish after a particularly heavy rush, Chief stopped rowing, and gazing at my face, contorted with emotion, remarked, "Ef yo' had to do it, sa', it would be mighty hard work!" Chief could never understand why I insisted upon doing all the hauling while he was paid to do it. Chief was plainly not a sportsman; he had never experienced the thrill 
of joy of the angler at the supreme moment of vantage gained; and so it is worse than useless to argue with the man who does not care for angling; he cannot understand that the angler is, as a rule, born, not bred.

One cannot philosophize with a wild unknown, battering and hammering at your arms, plunging, then rising to the surface with convulsive bound to turn and plunge again. There is a "second wind" in sea angling, and if the fish secures it, it is a sorry day for the fisherman, and seeing that the fish must be fought without cessation, I played it, hauling and giving with all my power, and in a few moments had the pleasure of sighting a magnificent fish at the surface, where it turned and beat the blue water into foam, tossed the Portuguese men-of-war into pearly fragments, and ground up scores of delicate jellyfishes which swarmed the warm waters of the Gulf. I held the game while Chief cleverly inserted his big gaff-hook beneath the head, and we held the monster hard and fast and rested our eyes upon the beauties of the black grouper, Garrupa nigrita, which, when towed in and hauled upon the beach at Long Key, was estimated to weigh three hundred and fifty pounds. 
This grouper attains a weight of six hundred pounds, possibly more. It is found in Brazil, Cuba, Porto Rico, and the islands of the Caribbean Sea, ranging as far north as Pensacola and the mouth of the St. Johns River; on the western Gulf coast it has various names. The large individuals are called the black jewfish down the reef; smaller ones of one hundred and forty or fifty pounds, by some fishermen, black groupers. The term "black" is to some extent a misnomer, as, while the fish appears black as it rises, its real color, at least in specimens I have observed, is a deep grayish or orange brown, or olive. Along this reef, and particularly near an old wreck a mile from Bird Key in the Tortugas group, where the barrier reef deepened, I took numbers of a smaller black grouper, Mycteroperca bonaci (Poey), a fish ranging from twenty to forty-five pounds, and found them very gamy. Crayfish bait was the most alluring. The tail of a crayfish, which I grained on the open reef early in the morning, was crushed on the side, which splits the shell down the back and renders it easy to open. This was cut into two long baits. The line used was a number twenty-one, attached to a three-foot, slender, copper-wire leader or 


\section{The Groupers}

snood. A large bait was necessary, as it was at once attacked by parrot-fishes, angel, and other beautiful bait destroyers, whose actions attracted the groupers, which darted at it and made a fine play, invariably poising for a second, with dorsals erect with excitement, then feeling the hook, charged to the sounding of the reel.

Another really beautiful grouper which can be commended to the angler is the hamlet, cherna criolla, or Nassau grouper, called by my boatman the white grouper. It is Epinephelus striatus (Bloch) of science. Its color is at times almost white, more properly a pale gray, but its normal tint is a light olive-green most beautifully barred with white or pearl-gray, while the head is striped horizontally, giving it a dashing appearance. The eye is a rich blue, and all together this fish is one of the most attactive of the tropical game fishes. I have taken it at Key West and all along the reef to the west, and it is a common fish in West Indian waters, where it attains a weight of fifty or seventy-five pounds. The large size of many of these fishes is unsuspected, as the giants are not desirable for market and often cannot be transported. I never saw a black grouper, a "white grouper," or a red 


\section{Big Game Fishes}

grouper in the market at Key West which weighed over ten or fifteen pounds. The largest fishes were often rejected, as they could not be conveniently disposed of ; hence few except reef fishermen know that many of the groupers attain such large dimensions or are endowed with game qualities.

Another fine and attractive grouper, the spotted grouper, Epinephelus drummond-hayi, may be classed with the large game fishes, specimens of which have been caught which weighed forty and fifty pounds; but the average weight of the species caught by me off East Key was but twenty-five pounds. The young fish of ten or fifteen pounds, often taken about large coral heads, afforded good sport. There are numerous small groupers, snappers, and grunts, belonging to the Florida fishing-grounds, which while comparatively unknown, would repay the angler who spends the winter and spring along the Florida reef. 


\section{CHAPTER XVI}

THE TARPON

"But lo, each wave to silver turns."

- William Sharp.

FEw anglers forget their first view of the tarpon. One saw the fish make a thirty-foot horizontal leap. Another sprang aside as a large fish fell headlong into the boat, passing through the bottom. Another viewed the silver monster coming like an arrow over the edge of a seine and dodged in time to prevent a repetition of the tragedy which had happened before. An angler in a boat being towed behind a river steamer saw a tarpon leap over him; and still another, sitting on the deck of a steamer, was made a target by one of these fishes, which fell headlong into his lap. Others have had a shark rise with their first tarpon in its mouth, literally shaking the silver king in their face; and many incidents might be given in the yearly history of this grand sport, showing how deep an impression the initial 
appearance of the tarpon makes upon the man with the rod.

I saw my first tarpon under peculiar circumstances at Garden Key on the Florida reef. I had a platform built beneath a wharf, where I could fish and watch certain fishes unseen, protected from the terrific heat; and one day when creeping to this vantage-ground I was amazed to see directly by my side, in water so shallow that its long dorsal spine was at the surface, a huge tarpon. It was perfectly stationary, and a better opportunity to observe the great fish with silvery armor was never afforded. The fish was at least six feet in length, and as I gazed down upon it, its back had a deep blue tint. I did not dare to move, fearing that the fascinating vision within my very reach would disappear, and for several moments feasted my eyes upon its fair proportions, when it slowly moved down the sandy slope into the deep blue channel and disappeared. What induced the great fish to take this position I could not conceive. The following day, with a cast-net boy and fishing-tackle, I went to Long Key, which at that time, previous to a hurricane which I understand washed it away, was a sandy island, about four feet high, fifty feet wide, and 


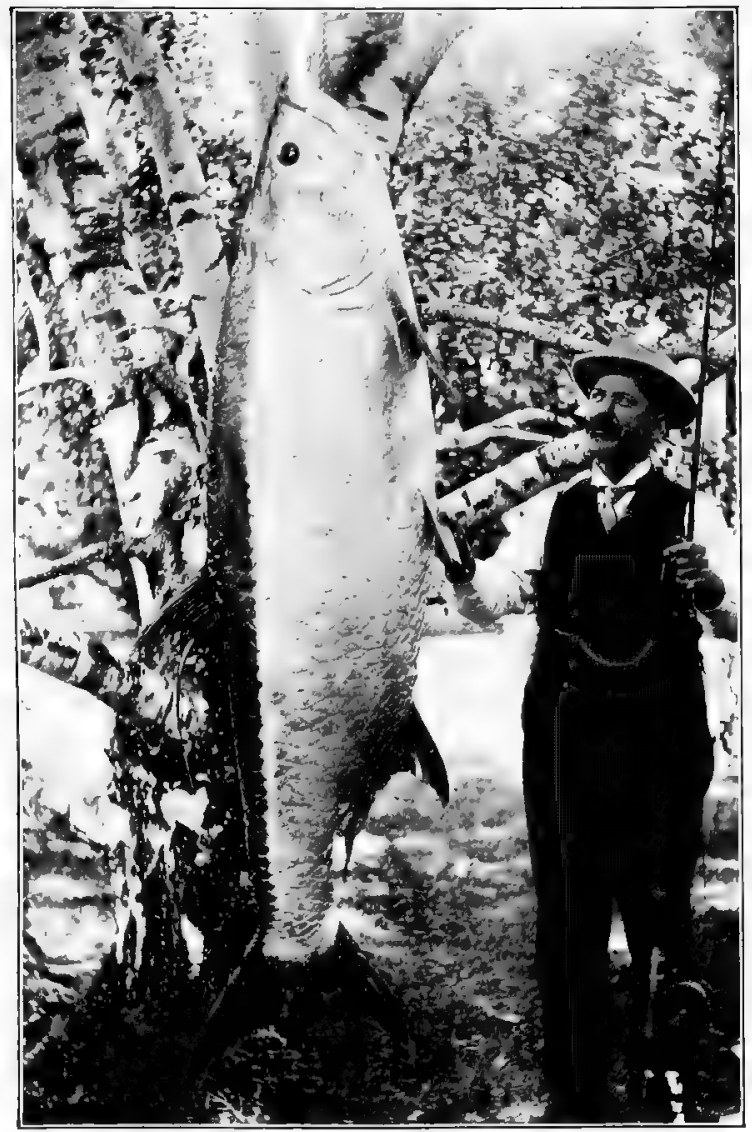

THE LARGEST TARPON EVER CAUGHT WITH ROD AND REEL

Caught by N. M. George, of Danbury, Conn, at Bahia Hunda, Florida, April 8, 1901. Length, 7 feet, 2 inches; girth, 46 inches; weight, 213 pounds full 



\section{The Tarpon}

nearly quarter of a mile long, which formed the western barrier of a large lagoon. Near the lower or southern end of this key the bottom rapidly dropped away from three or four feet into the deep channel. On the edge of this I cast a live mullet bait, which sank down into the channel, out of sight, my line resting on the sand over a windrow of shells, Portuguese men-of-war, Ianthinas, the purple sea-snail, and many more, tossed up by the sea. The coral sands were fairly alive with hermit crabs. Nearly every shell was preëmpted, and presently they were crawling over me with the curiosity of their kind; while out from myriads of holes came white spirit crabs, their glassy eyes alert, ready to dart back at the first alarm.

A strange place was this key, - not a tree or bush, nothing on or in the sand but crabs, and an occasional turtle's nest. While I was wondering how the young turtles escaped so many crabs, my line moved perceptibly, then ran into the water for a foot or two and stopped. By this time I was on my feet and had the line - not a moment too soon - as it ran swiftly out, I giving, hoping that it was a tarpon, yet fearing a shark. Perhaps fifteen or twenty feet of line slipped away; then 
thinking that this was enough for even the mouth of a tarpon, I allowed the line to come taut and hooked my fish, hooked it well, as up into the air, fifty feet away, rose a mass of molten silver, which, caught by the sun, flashed and scintillated in a thousand rays, and while in mid-air the splendid creature shook its massive head in a desperate effort to rid itself of the hook. Then down it fell, not gracefully, but like the swordfish, upon its side, tossing the water in every direction. Like a knife the line cut the water, throwing the spray as the fish shot away, taking the line, garnering it in yards. Only by mere chance was the fish turned to the right, so that its rush was up the key, upon whose beach we had been running and slacking to wed the fish from the deep channel. It could now be seen racing along near the surface in the great arc of a circle; now leaping into the air, shaking its massive head, endeavoring to plunge down, tossing its tail out of water, then falling, stopping aimlessly to thrash the water into a flurry of foam.

There was but one chance to save the fish, and this was to keep it in shallow water and gradually work it in; and as it rushed over the lagoon we ran, finally going out into the shallow water, 




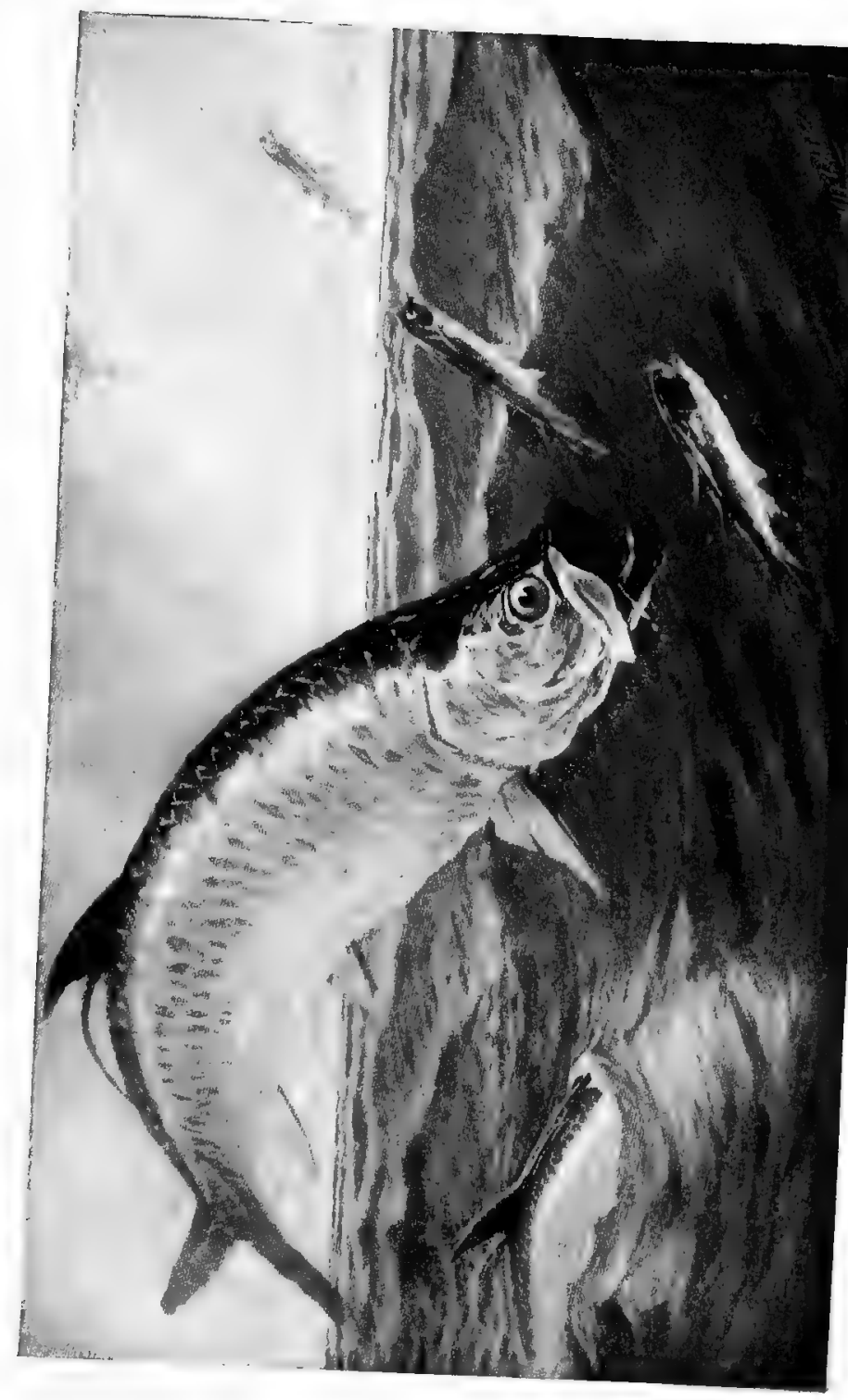





\section{The Tarpon}

waist deep, to save the line. The rush of the tarpon and our erratic movements started a school of large black nurse-sharks, which were sleeping here, into a wild stampede, which threatened the line. It was mere good luck that saved the tarpon, that now repeatedly left the water and sprang into the air, a glittering mass of molten silver, in the tropical sun. But foot by foot it was forced up the lagoon, and finally my baitcatcher, wild with excitement, literally threw himself upon it as I led it into the shallows, grasped it by the gills and dragged it out upon the sands, if not the same fish I had watched the day before, one of equal size, a thing of beauty, a joy forever.

It is difficult to convey an adequate idea of the regal splendors of the tarpon to those who have not seen it. Imagine a plain herring or sardine lengthened out six or seven feet. Imagine its scales newly minted silver dollars, frosted instead of stamped, silver dollars which have had the nacre of the whitest pearl in their composition, and some conception may be had of the glories of this radiant creature as the sun's rays flashed upon it, glancing and scintillating in every direction. The fish which lay upon the sands was about six feet in length and weighed possibly one hundred 
and twenty-five or thirty pounds; but this was an estimate. The tarpon is literally a gigantic cousin of the herrings, and its ties to the gamy ten-pounder, Elops saurus, and bone-fish, Albula vulpes, are still closer. It is included in the family Elopidæ, and after many nomenclatural vicissitudes is now, according to Dr. Jordan, Tarpon atlanticus (Cuvier and Val.), differing but little from an East Indian tarpon, Megalops cyprinoides.

In appearance the tarpon is long, slender, and thin, or compressed - the typical herring type. Its mouth is enormous and strikingly oblique, and when open, the gill-covers expanded, showing the blood-red gills, as often seen when leaping, it presents an extraordinary, grotesque, even cynical appearance. The lower jaw is very prominent, suggestive of a determination not to be caught; the teeth are minute, like velvet or plush (villiform), and the interior of the cavernous mouth is hard and difficult to penetrate. The eye of the tarpon is large and striking, and its glare has more than once given a novice a tremor, as the gigantic fish seemed to hang in the air dangerously near the boat. The dorsal fin is high but short, shaped like a lateen sail, the last ray long and 


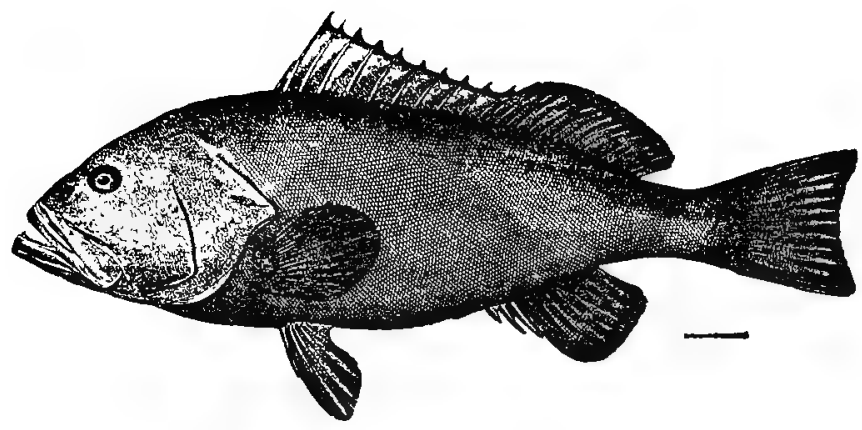

THE RED GROUPER

Epinephelus morio

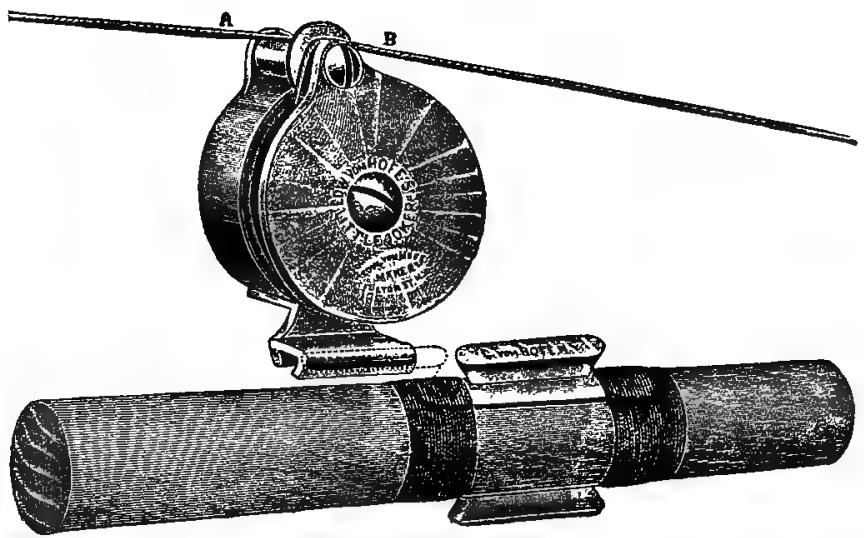

Actual Size of Joker

THE LITTLE JOKER

Used in Tarpon and Tuna fishing as a brake 

slender, reaching backward halfway to the base of the tail. The latter is deeply forked, a powerful organ by which the tarpon leaps. The most remarkable feature is the scales, which are enormous, the largest being three inches and a half in length. One in my possession measures three inches and a half by three, almost one-half seemingly covered with molten silver. The upper portion of the back has a metallic blue cast, appearing green in the water; the rest of the body is pure silver.

The tarpon is found along the Atlantic coast from Long Island to Brazil, but not in sufficient quantities north of Florida or the St. Johns River to assure sport. In the waters about the southern portion of the Peninsula, on both sides, it is very common, but is not plentiful on the extreme outer reef from Key West to Loggerhead. In six or seven years very few were seen. The localities famous for them on the Florida coast are in a general sense from the St. Johns to Biscayne, Indian River, Lake Worth, and Fort Meyer. Other localities made famous by anglers are Captiva Pass, Boca Grande Pass, Marco, Naples, Pine Island, and Homassossa. Here the fish is known as the tarpon or silver-king, but on 
the Louisiana coast it becomes the grand écaille, and along the Texan shore tarpon and savanilla. The tarpon is a migratory fish, moving north over the vast area of the Gulf. One pronounced migration is along the coast from Mexico, so reaching Louisiana; the other possibly passing up the Windward Islands, so reaching Key West or vicinity, following up the keys to the Cape, some following the west and others the east coast. I infer this from the fact that if the vast schools moved north in the centre of the Gulf, they would have been noticed at the Tortugas group, where, as stated, the fish is rare. Around Cuba and other islands some tarpon are found all the time, but they are more plentiful in summer at the Florida points; schools have been seen all winter between Key West and Cape Florida, particularly at Cæsar's Inlet. They appear in February, increasing rapidly in numbers in March, April, and May, entering rivers and streams as the Apalachicola, being seen, according to Stearns, eight miles from the mouth. I am indebted to W. S. Jenkins, chief engineer of the Aransas Pass Water Company, for much interesting data relating to the arrival of the tarpon in Texas. He writes: "The tarpon makes its appearance in 
Aransas Pass, lat. $27^{\circ} 50^{\prime}$ north, early in March of each year, coming from the south. During the months of March, April, and May they may be seen in schools of six to one hundred, coming up the coast from the south. Reaching the deep water of the Pass, they congregate in the gorge of the Pass for a while, as though to rest and feed, and then pursue their journey north along the coast to Galveston, Sabine Pass, and other points. From the middle of April to the middle of May they do not appear to take the hook or bait; during this time they are congregated in large numbers in the shallow bays and flats and can be approached easily in a small boat without displaying any alarm, and no lure will tempt them to take the hook. Apparently this is their spawning season. . . D During the latter part of May and in June the tarpon take the hook readily and seem eager for the mullet.

"The smallest tarpon I have measured was $2^{\prime} 9^{\prime \prime}$ long and weighed eleven pounds; but September 22, 1897, I hooked a tarpon which appeared to be but twelve or thirteen inches long. I lost it, so cannot say that I have seen the young taken. About the first of December the tarpon disappear entirely from the Pass. 
I believe that they go south or seek the warmer waters of the Gulf."

As to the spawning habits of the tarpon almost nothing is known, and the above information was in reply to some questions I propounded, hoping to obtain some definite facts. I watched the hauling of the seine several years at the Tortugas group, but never saw a young tarpon taken, so assume that it does not breed at this point. Mr. Barton W. Evermann found in his investigations among the fishes of Porto Rico, reported to the United States Fish Commission, that the fish doubtless made this region a spawning-ground. He says: "Common about Porto Rico, where it evidently breeds, as numerous immature individuals were taken at Hucares and Fajardo.

"The four examples are from Hucares, from 7.5 to 11.5 inches long, and were seined in a small, brackish pool of dark-colored water, not over 5 feet deep, in the corner of a mangrove swamp, and at that time (February) entirely separated from the ocean by a narrow strip of land scarcely 25 feet wide. The thirteen others are nearly all very young, of 2.25 to 3.25 inches, collected at Fajardo. No large individuals are seen." 


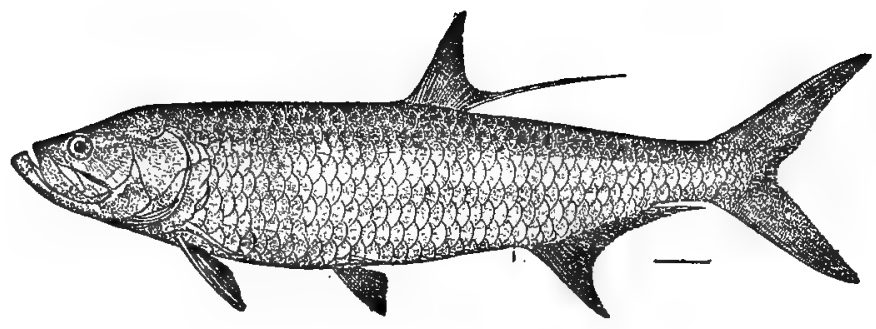

TARPON; TARPUM

Tarpon atlanticus (Cuvier and Valenciennes)

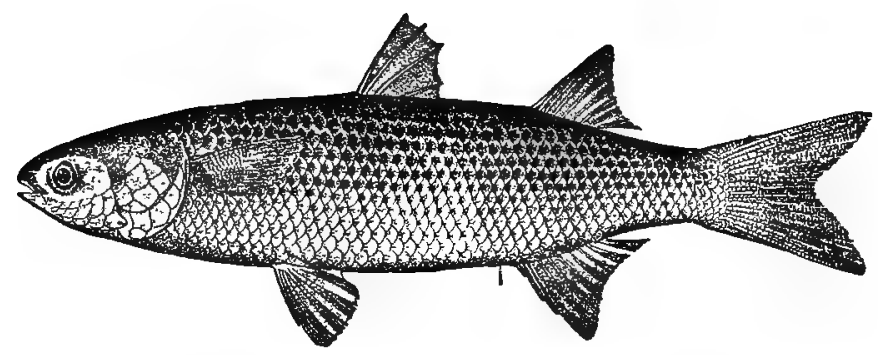

COMMON MULLET; STRIPED MULLET

Mugil cephalus (Linnæus) 



\section{The Tarpon}

The tarpon attains a length of seven or eight feet and a weight of four hundred pounds. Evermann states that a specimen weighing three hundred and eighty-three pounds has been harpooned, and from the descriptions of men who lived on the upper reef I am convinced that this is not the limit. In its habits the tarpon is a wandering, predaceous fish, preying upon sardines, mullet, and small fry of a similar nature. It devastates the schools, pursuing its course up the rivers into bays and over the flats, everywhere a rapacious fish, and by the fishermen where it is liable to be seined, considered dangerous, owing to its habit of leaping to escape. The tarpon is not valued in America as a food fish, and many fishes hooked for the sport are released, the large specimens being mounted as trophies. The tarpon has a value outside of its flesh. The beautiful scales bring from ten to twenty-five cents apiece in the market. Dealers use them for various purposes; and some anglers, as a piscatorial carte de visite, write their name, the date, and the weight of the fish on the inside, and send the alluring object to some distant angling friend, who is thus infected with the fishing-fever and made wholly miserable. 
The tarpon, ranked by its devotees as the greatest of game fish, is perhaps the only one which is utterly scorned as a food fish. I found my negro oarsman poring over an old geography one day at Garden Key, carefully measuring a map of Florida from Loggerhead up, with a foot rule. Finally he said: " Boss, disher's a mighty out-ob-de-way place. I's jes' reckonin', an' hit's jes' two hundred and fifty miles from a watermelon patch."

"Well, you have a tarpon, the finest-looking fish in the world," I said, referring to the one caught.

"Yes, sa', hit looks fine; so does hay. I'd rather eat hay dan tarpon, yes, suh, I would."

The great fighter is caught mainly for the sport it affords, its relations to the angler as game being similar to those of certain animals to the hunter, who often risks his life to obtain the skin. The tarpon season at Boca Grande, Captiva, Marco, Naples, and other places, is marked every year by remarkable sport, and now that railroads have opened up Florida and palatial hotels are found all alongshore, the angler can reach the best tarpon grounds with every comfort. At these places anglers from all over the civilized world congregate and try conclusions with this marvellous game, and as a result, boatmen have 


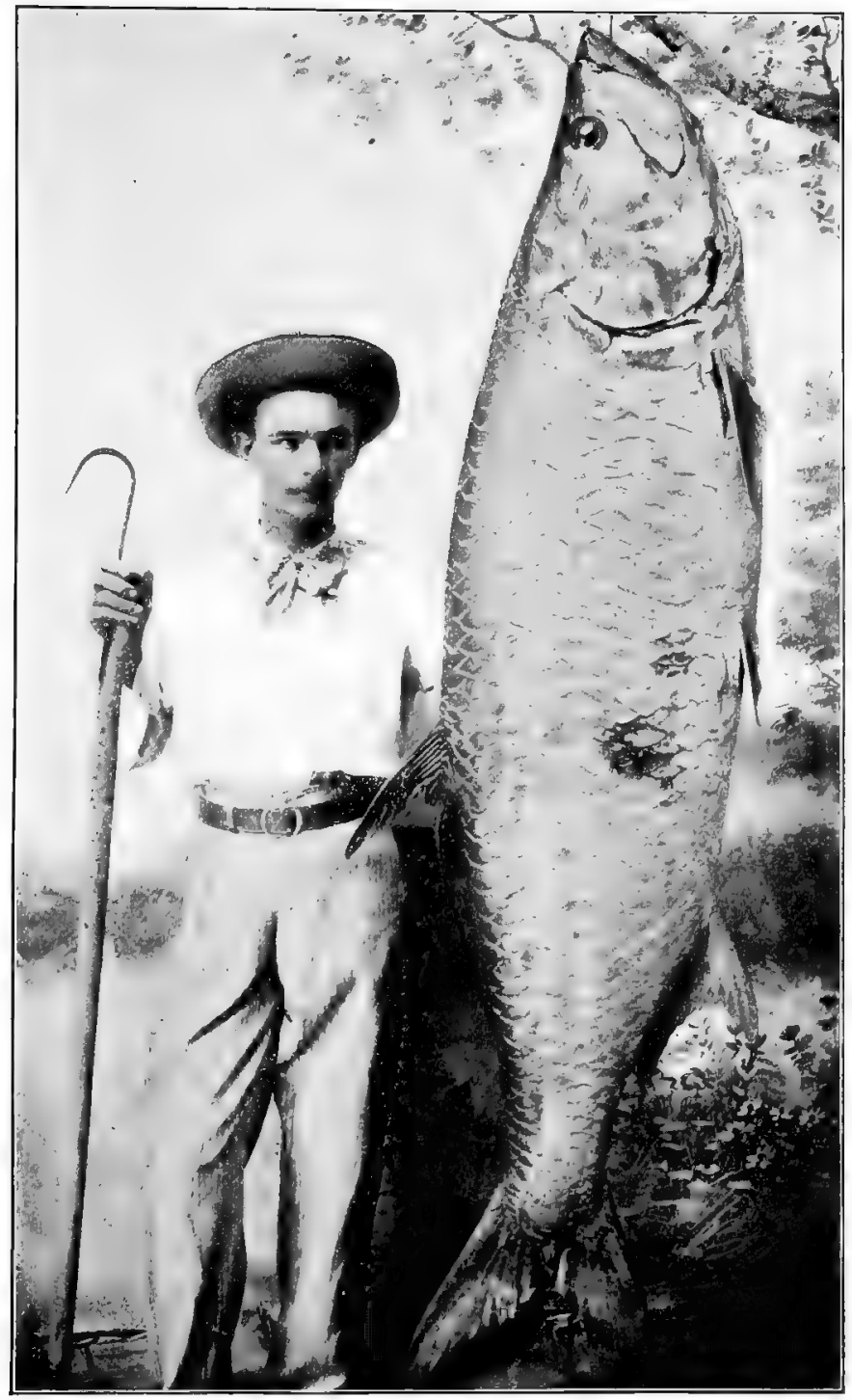

EDWIN VOM HOFE'S TARPON, 210 POUNDS, WHICH WAS THE WORLD'S RECORD FOR A TIME 


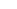




\section{The Tarpon}

developed, well schooled in all the requisites, and the sport can be fully enjoyed. Tarpon fishing with the rod is like tuna fishing - a modern sport - and was brought into public notice by Mr. W. H. Wood, of New York, the first tarpon having been taken in this way by $\mathrm{Mr}$. S. Jones of Philadelphia at Indian River Inlet. This historic tarpon weighed about one hundred and thirty pounds and was six feet in length, and fought the angler over two hours before it was brought to gaff. The fortunate boatman who shared the reflected honor was John Weier of New Smyrna. I well recall the interest aroused among anglers when it was announced that an angler wagered the expenses of any one to Florida who would take a tarpon with rod, reel, and light line. This was rash, as the fish had already been taken by Mr. Jones, but it was the introduction of this remarkable sport.

We will assume that the angler is at some of the resorts mentioned, or at St. James City, at Pine Islands, to reach which the train is taken from Jacksonville to Charlotte Harbor. Once on the ground, arrangements can be made to fish in the vicinity or any of the localities farther south. The question of tarpon tackle is important and 
is much a question of taste. It will be noticed that the men who have courted fame by bringing their fish to gaff in a short time use "club" rods, built, as a certain boatman sententiously said, for "snatching a tarpon bald-headed." But there are others who temper their methods with a modicum of humanity, and use longer rods and the lightest line that the conscience of the true sportsman will allow. Such a rod may be of snakewood, noib wood, or greenheart. It has a single long tip with a short butt, and when jointed is seven or seven and a half feet in length. The line is a number fifteen or eighteen, and the hook a ro/o Limerick, a Van Vleck, or an O'Shaughnessy of similar size. The snood, or snell, is a debatable question of vital importance along the tarpon belt. Some anglers use wire, but it is a shark country, and there are groupers, channel-bass, and various game which become vermin when the mind of the angler is concentrated on tarpon alone, hence a soft snood is preferred, that the shark may sever it and cause no delay in the real work cut out for the day. The hard jaw of the tarpon easily files off a slender line, so a compromise is effected, and a stout cod-line snood is used by some; others again employ a moose-hide snood, and there are 


\section{The Tarpon}

others. A large multiplying reel is necessary, one that will hold six hundred feet of wet line, and this should have a leather thumb brake. The regulation tarpon reels are fully equipped, and in point of fact the tuna and tarpon outfits are alike with the exception of the snood, which in tuna fishing is always of wire and very long. The boats employed vary in localities and are ordinary light, serviceable, lapstreak boats, with a seat for the angler or anglers to face the stern.

The boatman having secured a catch of mullet, you are off for the grounds, with a choice of methods depending upon the boatman, the place, or its traditions. You may anchor on the edge of deep water, anchor inshore, or your boatman may row, the gamy fish being taken in various ways. Some anglers refuse to have the boat cast off, preferring to fight to the finish from the anchorage. Assuming that the boat is anchored in a favorable position, the mullet is cast thirty or forty feet distant, and the waiting, that is an accompaniment of all sport, begun. If there has been a norther, if it is a late season, if cool weather has been the rule for some weeks, the wait may be a long one, and there is a tradition of a man who never had a strike, yet is fishing on and on, a 
piscatorial Wandering Jew. If it is very hot, there is more chance for an early strike, as the tarpon evidently prefers warm weather and the resultant warm water. Some wit has described this phase of tarpon fishing as sitting in a Turkish bath holding a string; but the heat in this part of Florida is cool compared to the still days where I have fished far down on the outer reef. Despite this uncertainty, the angler should take for his motto, Nunquam non paratus, and live up to it, as a strike is liable to come at any time. There are a thousand and one diversions in Florida to occupy the angler, who of course is a lover of nature, even if the fish are not biting; and again it may be the day of days when the game is in the Pass and fish are seen at once rising all about, flashing here and there. Such a day Mr. O. A. Mygatt of New York found at Boca Grande on May 26, I898, when he took twenty-two tarpons, which I believe is the record; while at this famous locality Mr. W. H. Grenfell of London took one hundred fish between April 19 and May 10, - both of which cases illustrate the possibilities in this sport of sports.

We may assume that it is a fishing day. Presently the line begins to run out, and you aid 
the big reel, overhauling the line, paying out, $z e-z e-z e-z e !$ until perhaps twenty-five or even thirty feet have gone. This is the method of many successful tarpon anglers, but not my own. By this time you fancy that the tarpon has bolted the bait, and you give it the butt as the line comes taut, forcing the hook into its big throat. Up into the air it rises, looking so big, shaking so fiercely, that you wonder if such a monster can be caught. At such a moment a tarpon has tossed the baited hook yards away, dropped to the water with a crash and leaped, wild with fear, pain, or astonishment, still believing itself hooked. A tarpon in such a frenzy has been seen to throw itself an estimated thirty feet along the water. Sometimes it rises near the boat, again fairly alongside. But your fish is headed away, and as your boatman has hauled up the anchor, you are off behind this silvery king. Now it threatens to take you out into the surf in its wild rush for the Gulf - now it is in the air, a splendid glittering object, the type of activity. Two or three hundred feet of line have been taken in the succession of rushes, and despite your utmost exertion, your pumping and fighting, the tarpon holds its own, is still king; but in the 
end you win, and after half an hour, or perhaps it is two hours, the tarpon is alongside. Your boatman gaffs it and deftly slides it into the boat, and as you lean back, worn, weary, dishevelled, a finger nail gone, perhaps, two knuckles bleeding where the handle of the reel caught you at the last rush, yet you are happy and delighted; and so far from being discouraged, you are now determined to hook a record fish if it takes all summer.

Such may be the experience of an angler in Florida. At Captiva Pass, Mr. Edwin vom Hofe of New York took his two-hundred-andten-pound tarpon, which was for many years the record, and I believe still holds for this particular region. It was exceeded by $\mathrm{Mr}$. N. M. George of Danbury, Connecticut, who took with the rod, at Bahia Honda, April 8, I90I, a tarpon which weighed two hundred and thirteen pounds. Its length was seven feet two inches and its girth forty-six inches.

This, then, is the record for American waters. This catch was exceeded by Dr. Howe at Tampico, Mexico, his fish weighing two hundred and twenty-three pounds. All these catches stand on a weighing basis. R. E. Farley of Aransas Pass informs me that C. W. McCawley of Dallas, 


\section{The Tarpon}

Texas, landed on July I 7 , I90 I, a tarpon seven feet ten inches in length, with a girth of forty-six inches. This fish, unfortunately, was not weighed. According to the formula given, this would indicate a fish weighing two hundred and thirtythree pounds, doubtless the record fish; but in a question of records weight alone is accepted. A fish taken in Corpus Christi Bay, near Aransas (on a hand-line, so I understand), was eight feet three inches in length and weighed two hundred and nine and a half pounds. I have seen a photograph of this remarkable fish, and it was very long and slender. If it had been in the best condition, doubtless it would have exceeded any fish taken with line.

The question of records is an important one to the angler, who has, it must be confessed, a single weakness manifested in pride in the capture of a large fish; hence certain safeguards must be thrown about the question. There are records with the harpoon, records with the handline, but the true record of the sportsman-angler is the rod record, - in a word, the catch made in a sportsmanlike manner, as that of Mr. George or Mr. vom Hofe; and there is an unwritten rule that the record weight must be that shown 
at the weighing, and shall be attested by witnesses. I made the draught of the original rules of the angling tournament of the Tuna Club, and suggested that the club demand that contestants use a fairly light rod, theoretically not over twenty-six ounces in weight, a line not larger than a twenty-four cuttyhunk; that the fish must be brought to gaff unaided, any breakage or assistance from boatman debarring the angler. This assures a contest between one man and the fish, the chances on the side of the latter. It is astonishing how a fish will grow in the hands of a determined and enthusiastic boatman. I recall one who always claimed that the scales were "shy four pounds." He then added two pounds for loss of blood while playing, two more for certain "shrinkages and evaporations" before it could be weighed; then this true and cheerful soul would throw in an extra pound for luck, and was prepared to take affidavit that the weight was correct. My catches were the envy of the reef when Billy — had the weighing. And then to hear him announcing the weight to others! Then it was that he soared to the very empyrean of the imagination. The arguments that he had to sustain his premise, the impressive manner 
in which he swore to the double weight, the evident fact that he convinced himself that he was right, were all delightful features in these fishing days when records were not thought of. I once caught with his aid a three-hundred-andfifty-pound jewfish and frequently told the story. After several years I met Billy, and in his presence related the experience; but when I mentioned the weight, his face assumed an expression of surprise. "Why, sir," he said, "you forget, sir, that I weighed that fish, and it weighed five hundred pounds, sir," this so seriously that no one could hold out against it; doubtless it was five hundred pounds, and I was mistaken. This boatman was an Irishman, a second Paddy Farriell of Kinsale, whose angling lines have made John Lander famous in the annals of angling poetry. You will remember that Paddy thus writes to his friend Thady Mullowny and beseeches him to come down and try the fish of Kinsale, sending him a hake through the mail as a sample of the big fish then biting:-

"We've a choice set of books for the student who wise is,

The eel of true science to seize by the tail;

At all seasons a skate you can have where no ice is,

Or a sinecure plaice you may get at Kinsale." 
Back to Paddy came this rollicking answer:-

" Dear Paddy - I got your poetic epistle,

Along with the hake that you sent by the mail ;

But what could bewitch you to sing, or to whistle,

In strains so melodious the praise of Kinsale?

"In all baits you're well skilled, you cod-dragging curmudgeon,

To hook every fish, from a sprat to a whale ;

But your lines shan't catch me - by my soul, I'm no gudgeon

To flounder or starve in the streets of Kinsale.

"I know your design is, as usual — sell - fish ;

For catch what you will, my old boy, I'll be bail,

You'll jolt off to Cork your best hake and best shell-fish,

And leave barely a claw for the town of Kinsale."

Texas should add the tarpon rampant to her escutcheon, as sooner or later the fame of this splendid fish and the remarkable fishing found along her shores will become one of the prime attractions of this region. That I might speak from first hand and describe the capture of the Texas tarpon from actual experience, I made the trip to the Gulf coast in July and August, I902, finding the fishing at Aransas Pass far beyond my expectations, and what was more surprising, the grounds tempered by a cool breeze which made the sport enjoyable and in every way satisfactory. 
The tarpon is found all along the coast of Texas, but the centre of interest is Aransas Pass, a narrow cut between St. Joseph's and Mustang. islands, eight miles from the mainland. On the former stands the fine club-house of the Tarpon Club, whose hospitality I enjoyed through the courtesy of Judge A. W. Houston, its vicepresident, a devoted tarpon angler of San Antonio. On Mustang Island is the little town of Tarpon and its one hotel, Tarpon Inn, where the angler will find excellent entertainment, good boatmen, and tackle, if perchance he is without it. Aransas Pass is reached from New York or California via San Antonio, the Sunset Route being the most direct in either case. At San Antonio the Aransas Pass road in a few hours takes one to Rockport, from which there is a daily mail-boat down the fine bay of Aransas fifteen miles, to the Tarpon Club or Tarpon Inn. The fishing season here is from April to December, and possibly the angler would find it cooler in October, when, I was informed, the fish are in the inner Pass; but I found the conditions excellent in August, a cool breeze blowing night and day and the fish biting. I fell into the hands of one Mateo Brujen, one of the many skilled boatmen here, and 
in ten minutes after reaching the Pass I was playing my first Texas tarpon; and of six boats which made up the party, all had fish or strikes soon after reaching the ground. I fished with a rod eight and a half feet long, a twenty-one cuttyhunk line, using a large tuna reel of Edwin vom Hofe make, containing six hundred feet of line, a Van Vleck hook with a three-foot phosphorbronzed wire leader, or snell, the boatman doubling the line for about a foot beyond this. The bait was a live mullet not over four inches in length, hooked through the lips, and with thirty feet of line out I began fishing.

My boatman rowed slowly along the jetty, not ten feet distant, where the water was shallow. The tide was slack, the water smooth in the channel, but breaking heavily on either side. That tarpons were plentiful was evident, as every few minutes the back of one would be seen; and as the boatman rowed out beyond the jetty I had my first strike, and with the best of luck hooked my fish. Up into the air four or five feet went a splendid mass of molten silver, to fall with a crash, only to go up again, this time tossing the bait at me with such force that it fell on the gunwale. As the fish reached the surface, it 
made a fine run of one hundred and fifty feet which was irresistible. The boatman shouted that a shark was after it, so I forced the fighting while he backed water. Up into the air went the silver king on the crest of a big roller, falling broadside and still hooked, as I had with the big multiplier kept a taut line; then it stopped and came toward me, sweeping around in the arc of a circle, making a splendid leap so near the boat that I fancied I heard the boatman gasp; perhaps it was myself. Nothing could be more gamy, more magnificent, than the play of this fish, as rushing, leaping, coming in, bearing off, always on the surface, it fought its gallant fight for fifteen minutes or more, until I brought it successfully to the boat. As near as I could estimate, the fish was six feet in length, as we lost it after having towed it nearly to the beach a mile distant.

By this time two other anglers were playing tarpons, and the scene was intensely exciting and sensational, especially as a gaffed tarpon very nearly wrecked a neighboring boat, overturning gaffer and angler in the mêlée. Tarpons were now leaping here and there, and I turned my attention to attempts to photograph them, one angler forcing his fish to jump for my benefit and 
with a thirty-seven cotton line endeavoring to trip or throw it in the air.

At times, when a dozen or more boats have been fishing here, six or eight tarpons have been seen in the air at the same moment, and the lofty tumbling productive of much entertainment. A large fish hooked by a member of the Tarpon Club leaped over the boat of Judge Houston; and a fish hooked by another angler leaped into the air and struck the chair of the occupant of another boat, almost knocking him overboard. In such a whirl of excitement it is evident that angler and boatman must be on the alert, not only to secure their own fish, but to avoid the air rushes of the frenzied game of some one else.

The second tarpon I hooked was kept at short line especially to observe the leap, in a hope to photograph it; but when the splendid creature went into the air higher than my head, not ten feet distant, hurling the spray over me, I confess that all thoughts of the kodak vanished. When in the air, the fish was apparently headed for me, but it dropped alongside with a crash, and as the warning of the boatman came, fearing that the fish would come aboard, it dashed by me three feet under water, canted upward at an angle that 
caught the sun's rays, a blaze of silver, and before the boatman could whirl the skiff about I saw it gleaming in the sunlight over my shoulder, high in air again; then, despite my pressure on the rubber brake, it was away, fifty, a hundred feet, literally to rise into the empyrean like a bird again and again, and with wide-open gills endeavor to throw the deadly hook from its jaws.

While I was trolling, ten-pounders, here called skipjacks, were darting into the air, their leaps being very similar to those of the crazed tarpons. For fifteen minutes or more this gamy creature fought and leaped, then coming to gaff with vigorous protest, and was only landed in the skiff after great difficulty, though only five feet three inches in length.

Having taken all the tarpons I desired, I devoted my time to observations of the vaulting feats of this gallant and spectacular fish. Those who have read the lines on tuna jumping will, perhaps, have noticed my reticence, as I realize how easily one may be mistaken; and in the case of the tarpon I have the same hesitation, yet fear I may do injustice to this marvellous jumper if I do not refer to it. I was particularly desirous to determine the effect of the side swing of the 
tarpon in mid-air on a taut line, and began trolling with a line not over fifteen feet out - a seeming absurdity; yet my boatman assured me that along the jetty this was often effective, and he was a true prophet. The strike soon came and I responded at once, possibly giving the fish the benefit of a foot by dropping my tip before striking, then repeating it twice at least; in a word, attempting to hook the tarpon as I would a tuna on the instant. In every instance this was successful, and I did not miss hooking a fish, trolling at a speed of two and a half miles an hour; those lost, with one exception, were while I was towing them in after I had brought them to the boat - a disagreeable process and one that would be unnecessary if a good raft was anchored in the lee of the jetty. When I hooked a fish with the short line, it went into air so near the boat that my boatman feared that it was coming aboard ; but, fortunately, I was able quickly to give the reel handle a twirl so that the fish was in mid-air with a taut line. The tarpon had its mouth and gills open, and as nearly as I could judge it made two convulsive lateral swings before it fell, merely jerking a foot of my line from the reel, the anti-overrunning drag coming into play here. The fish dropped heavily, 
and I held it with all my strength, right thumb on the reel-pad and left thumb and forefinger on the line above the reel, stopping the tarpon despite its struggles and resulting, as I had expected, in another frantic leap almost alongside.

This jump may have been seven or eight feet. I attempted to throw the fish from its position in mid-air merely as an experiment, but failed to effect it; with a heavy line this could easily be done, from all of which I deduce that with a good drag there is no reason why a taut line should not be kept when the tarpon is in air. As to the height the tarpon attains when leaping, Mr. Waddell states that he saw a fish, hooked by Mr. L. G. Murphy of Converse, Indiana, make an initial leap of twelve feet and follow it with six leaps all equally high. He says, "The ordinary height a tarpon leaps is from seven to eight feet." This agrees with my observations, and that the fish attains the highest jumps of the tuna is shown by the statement of Mr. Mason.

The time of my visit was considered an unfortunate one, owing to the fact that the recent floods had filled the water with mud, which seriously interfered with the fishing; yet, at its worst, I doubt if there is anywhere else such tarpon- 
fishing or so many fish constantly in evidence. This is best illustrated by some of the records of the Tarpon Club and the Tarpon Inn. Up to August 8, 1902, the rod catch of the latter place in the half season was over three hundred, and Mr. J. R. Wainwright of Pittsburg, Pennsylvania, had taken one hundred and seventy-four fish, ranging up to six feet in length, his best catch being thirteen in one day, the fish ranging from five feet ten inches to six feet three inches. A number of ladies have made records at the Tarpon Club, and Miss Houston, daughter of Judge Houston, vicepresident of the club, killed the record fish of the season of 1902 after a hard contest with the gamy silver king, which was six feet six inches in length. Miss Hampton, daughter of General Wade Hampton, brought fifteen tarpons to gaff during her visit to the club.

Not alone in Texas do ladies hold records, as previous to the capture of the two-hundred-andten-pound tarpon at Captiva Pass by Mr. Edwin vom Hofe, the record was held by Mrs. George T. Stagg of Kentucky, who, single-handed, brought to gaff in May, Igor, a silver king which weighed two hundred and five pounds.

From July 20 to August I7, I9OI, Mr. J. T. 
Mason of Denver took eighty tarpons at Aransas Pass, and his record for 1902 was even more remarkable. Mr. Mason observed a tarpon leap fifteen feet over a boat containing two men, clearing the men's heads by ten feet; and doubtless this is sometimes exceeded. If the records of this exciting fishing-ground could all be told, they would test the credulity of many who do not go down to the sea to fish. Judge Houston and a friend landed nineteen tarpons in two and a half days' fishing, which is a remarkable feat when the activity of the fish is considered.

The fishing at Aransas Pass is mainly trolling, and nearly all fish not desired as trophies are towed to the beach, hauled up, measured, and after a scale is taken, released. Few fish are weighed here. If the angler is curious as to the weight of his catch, he uses the following formula, which gives a good general average: Weight in pounds is equal to the square of the maximum girth in inches, multiplied by the length in inches, divided by eight hundred. The Texas tarpon is by no means particular as to bait. I found that live or stale bait was equally acceptable, and a variety of fishes can be used as lures. The tarpons begin to gather in the Pass in October, and the first 
"norther" in November sends them south, the season closing by the first of December, when tarpons appear to be crowded out by the ducks. To Dr. H. W. Howe of Mexico lovers of this strenuous sport are indebted for the discovery that the tarpon winters as far north as Tampico, and that there is excellent fishing here in January, February, and March; hence the travelling angler can find tarpon fishing if desired every month in the year, between Florida, Texas, and Tampico.

In an interesting and valuable series of articles in Forest and Stream, Mr. Waddell gives many interesting facts relating to this gamy fish in its winter home. He believes that it is more gamy at that season. According to Mr. Waddell, the Mexican tarpon ascends the river Panuco forty or fifty miles, and a small one was taken in the Papaloapam River one hundred and twenty-five miles from the Gulf. The Mexican tarpon record, according to the same authority, is a two-hundredand-twenty-three-pound fish, six feet eight inches in length, caught at Tampico by Dr. Howe of the city of Mexico.

This catch will stand as the world's record. In a letter to me Dr. Howe said: "My fish weighed 223 pounds six hours after it was caught. Its 


\section{The Tarpon}

length was only six feet eight inches, but it was built more like a jewfish than a tarpon [that is, very deep]. It showed its head above water but twice." Dr. Howe played this record fish from eight in the morning until half-past eleven, or three hours and a half, before it was brought to gaff.

The Texas tarpon, like other fishes, varies much, some medium-sized fishes making a fight that involves the angler in a long and arduous contest. One, despite his efforts, took Mr. Cotter of Tarpon down the Gulf coast through the breakers for several miles. Others are brought to gaff in from fifteen to twenty-five minutes, and if the shark was not a factor to be considered, a number fifteen or eighteen cuttyhunk line would be admirably adapted to the sport; but when a shark appears as a contestant, demanding its pound of flesh, sometimes the entire spoils, it is necessary to force the fighting, which can be done with a number twenty-one cuttyhunk line and a short rod.

The tarpon angler will be puzzled by the different weights of fish of nearly the same length. I brought to gaff a tarpon which I estimated was six feet in length, yet it was long and slender, and 
its weight doubtless not over one hundred and twenty pounds. Mr. vom Hofe's record fish was but six feet eleven inches, yet weighed two hundred and ten pounds; and Dr. Howe's tarpon, which weighed two hundred and twenty-three pounds, was three inches shorter than the above. The truth is, that the maximum length of the tarpon is about eight feet, a long, slender fish; but mature fishes, or those which have had very favorable food conditions, fill out, become exceedingly robust, thus materially adding to their weight without affecting the length.

The midsummer tarpon grounds of Aransas Pass are tempered by a cool, constant breeze. The health conditions are apparently perfect, with a complete absence of malarial taint and few, if any, mosquitoes. In fishing from eight to twelve, or four hours, daily, and sometimes in the afternoon, the angler may expect to take from one to five tarpons a day. In a month's fishing by Mr. J. T. Mason, referred to, he drew but two blanks. On nine days he took four fish and over. On eleven days he took either two or three daily. This, with the remarkable average of Mr. Wainwright, of one hundred and seventyfive tarpons for but half of the season of 1902 


\section{The Tarpon}

or up to August 8, will give the reader a fair idea of the possibilities of sport in this part of Texas.

This chapter gives experiences in fishing in Florida and Texas, but possibly the would-be tarpon angler and novice may desire some explicit directions, which, however, are naturally influenced by personal likes and dislikes. I have frequently in these pages voiced the sentiment that anglers obtain the fullest enjoyment in the possession of their own tackle, and that it often means the capture of the fish goes without saying. We may assume, then, that the layman has been enthused to the tarpon-taking point and looks about him for an outfit. Many experienced tarpon anglers advise the making of tackle, that is, the snell or leader, some even making rods. I note that $\mathrm{Mr}$. Mason made his own rod. A very successful rod can be made by selecting a good bamboo pole, cutting it down to seven feet, buying a reel seat and German silver guides and attaching them; yet I would not advise it. Good tarpon rods are works of art, and they are produced by experts in their line by the great tackle dealers of the country. In this sport one wishes to take no chances, hence I would suggest to the would-be angler to buy or order from some one of the old firms a tarpon rod 
complete. Personally I am an advocate of rods longer than those generally made for the purpose, and have demonstrated that tarpon can be taken with them; but the regulation rod is of noib wood, greenheart, or split bamboo. I would suggest the first - a species of greenheart of excellent properties. One which I have used has a short, hard rubber, silver-mounted butt, with a long tip with double bell-guides, and is six feet nine inches in length and weighs twenty-six ounces. With one tip the rod costs $\$ 17$; with two tips $\$ 22$. An excellent rod is made of split bamboo; indeed, Mr. vom Hofe took a six-hundred-pound fish with a standard tarpon rod of split bamboo seven feet in length. Another noib-wood tarpon rod is seven feet three inches and weighs twenty-four ounces. My best tarpon rod was eight and a half feet in length, but the novice should remember that the difficulties in landing a fish increase with the length of the rod. One rod of this kind is sufficient, though two are better, and they should be carried in a stiff leather rod case made for the purpose. How much depends upon a reel every veteran angler knows, and there is but one for this fishing, the best; not necessarily the highestpriced, but one of a make that has stood the test. 
A cheap reel will go to pieces sooner or later. The desirable reel costs from twenty dollars upward. It must hold six hundred feet of wet twenty-one cuttyhunk line, or some good line of equivalent size. It can be fitted with one of the several good drags on the market if desired, and should have a leather or rubber thumb-pad fastened to the cross-bar to press against the line. The line must be of the best quality; a number eighteen is large enough for a cool, skilful angler, and with it the largest fish can be killed; but for an angler in his novitiate a number twenty-one or twenty-four is better. Such lines cost from three and a half to four dollars - and the fisherman will do well to have several, especially if the fishing is away from the haunts of men or dealers. In the matter of hooks, quality and quantity both must be observed. The Van Vleck is a favorite with all tarpon anglers, and is the result of keen and intelligent observation on the part of an ardent tarpon angler. The ro/o O'Shaughnessy is an excellent hook. The latter is fastened to a leader or snell of phosphor-bronzed wire at least five feet in length, divided into three lengths, each connected by a swivel. The angler can make his own leaders. If so, a small vise and pincers of 
several kinds and a supply of wire are necessary. This gives one something to do on rainy or off days; but I believe I am offering good advice when I suggest that the angler lay in a supply of ready-made leaders, several dozen at least from the best makers. These will cost from fifty to eighty cents apiece complete. I would suggest that the angler have a box made by some dealer. which will hold the reel in the centre and on the sides the lines and mounted hooks. There should be room in this box for a revolver, several pincers, a set of miniature tools, - the kind which stow in the handle, - a flat file, a patent oiler, a piece of chamois skin for the reel, some sandpaper, a knife of bowie type, a few pipe sinkers, a brass line drier, some fine copper wire, a spool of silk for repairing, sticking plaster, and some simple remedy for abrasions, etc. These can be so stowed that the convenient "grip " holds all the necessary articles except the rod. If the angler is going away from well-known grounds I would suggest a gaff, spear, shark-line, and several hooks. On the reef my boat was equipped with all these appliances and I frequently found them convenient.

In making up such a box the novice can obtain the advice of the dealer, who should be familiar 
from personal experience with all the fishinggrounds. A leather rod-rest or socket is a convenience. They come for the boat seat or waist and cost from two to three dollars. One for the seat is not only a luxury but a necessity. Such an equipment, and it may be varied, will be a pleasure aside from its actual use, and if the fishing is in out-of-the-way parts of Florida, it is almost essential, though at some points good tackle can be purchased. At Aransas Pass the best tarpon tackle is for sale, but if the angler is starting from New York, he will have better "luck" to equip there, thus taking no chances, as small dealers are liable to be out of certain rods or reels.

Arriving at the grounds, the angler selects his boatman, a man of experience, in a short time learning the peculiarities of the grounds. On the morning appointed he finds himself in the Pass. The rod-rest is screwed on to the seat between his legs. The line which has been stretched, if new, the night before, is wet; and the boatman lashes the reel to the rod whether it has a patent fastener or not, reeves the line, fastens the snell to it, and baits the hook, while the angler, seated in a comfortable chair, reels off the line with his left hand the number of feet suggested by the well-posted 
boatman, - it may be forty and it may be fifteen. I hooked several tarpons with the latter length, and saw the magnificent leaps close aboard, too close for actual comfort if the truth were told. The angler now holds the rod across his lap, pointing over the quarter to port and slightly up, never astern, and at its best nearly at right angles to the boat. His right thumb rests upon the thumbbrake, the left grasps the cork-grip above the reel. The boatman is rowing at a speed of about two and a half miles an hour, and if he is the man I take him to be, he is rich in expedients in warding off ennui. At the exact moment the novice begins to be discouraged he invariably sees a tarpon, or hears one grunt or puff, and thus deftly carries the angler along, keeping him on the alert until the strike really comes. This is an epoch in the angler's life, a bright moment in what Byron terms that "solitary vice" of angling. What to do and how to do it well is the question. If the angler follows my suggestion, he will sway the point forward, then strike at once; but if he accepts the dictum of many others with possibly far more experience, he will give some line, on the ground that as the interior of the mouth of the tarpon is hard and bony, it must swallow the hook, which 
will become impaled in the throat. I may be hypercritical, but I would rather lose a fish than play it with my hook embedded deep in its throat. If the hook strikes an impenetrable portion of the jaw, it will, especially if two or three strikes are made, slide along and find a soft place in the angle of the jaw; at least I have rarely failed to hook my fish when trolling, by striking at once; and with apologies to other and better anglers, I commend the quick strike, and by strike I mean the retort courteous to the "bite" of the tarpon. It must not be a jerk but a powerful backward sway, the thumb pressing hard upon the leather brake. The fish will at once jerk away; but the angler can repeat the strike from one to three times, thus "setting" the hook in its jaw. The fish struggles violently, and the angler holds the rod up as firmly as possible, "giving the butt," then slipping it into the leather socket. At this precise moment the well-regulated tarpon should go into the air from three to twelve, or more, feet - a bewildering, dazzling vision, the silver king of vaulters, and fight and struggle

"Till floating broad upon his breathless side, And to his fate abandon'd, to the shore You gayly drag your unresisting prize." 
Despite all efforts to hold it, it breaks away, and to the merry jangle of the reel goes bounding along half across the channel, tearing the line from the reel, until the novice is amazed at the strength and power of the fish. Up into the air it goes, again and again, and with two hundred feet gone the angler stops it and begins to reel, and here often meets his Waterloo. The angler should be perfectly cool, prepared to transfer hand from brake to reel handle and back with great rapidity; he must not hold the fish by the reel handle - often a great temptation; the rushes must be stopped by the thumb and upper hand pressure, and the moment this is accomplished seize the reel handle and turn, then drop the tip to the water's edge, or very low; and with both hands, the right on the brake, lift steadily back until the rod is vertical, then lower the tip suddenly, reeling rapidly. This is "pumping," already referred to, and by it the angler gains several feet with ease; in fact, deliberately to reel in a hard-fighting tarpon out of hand, without resorting to this expedient, is at times almost impossible. By a series of short "pumps" the fish comes in rapidly, but the angler should be watchful, as the fish, if it is thoroughly game, 
will make many desperate rushes and leaps which seriously interfere with the best-laid plans of the most astute angler; but if all goes well, in from fifteen to thirty minutes the fish should be alongside. The angler holds it firmly, then passes the tip of his rod forward, on the port side if he is right-handed, and the game swims into the field of the gaffer, the angler's right thumb on the pad; the left hand may now steal to the reel to overrun a foot or two as the gaffer does his work, but he should hold himself well in hand, as the work is not complete until the fish is in the boat; at any moment it is liable to make a rush and escape. I have seen a large fish leap out of a barrel ten minutes after it had been gaffed and its capture supposed to be a closed incident.

If the fish is not desired as a trophy, the gaffer seizes the doubled portion of the line and holds it at the gunwale, inserts a short gaff just beneath the lower jaw and holds the fish while it is unhooked and cast off, perhaps to be caught again. If the fish is to be kept, the gaffer does not touch the line, nor does he attempt to gaff until the fish is in position; then the gaff is placed under the head and jerked heavily upward be- 
tween the gills and the tip of the jaw, and the fish's head held partly out of water against the boat, while it struggles. Some anglers kill the game with a revolver, or stun it with a club. It is a dangerous experiment to take a living tarpon into a light boat, as a lusty fish will wreck a skiff, and has been known to throw all hands overboard. Assuming that it is in condition to take aboard, the boatman steps on the rail, forcing it to the water's edge, and slides the fish in upon the canvas which should cover the bottom of his part of the boat and which, if the tarpon still struggles, can be thrown over it. If the fish is firmly hooked, the boatman now cuts the line, or unfastens it, and baits a new hook; hence no time is lost if fish are biting.

I have seen tarpon fishing described as requiring no skill, but no more laughable picture can be seen upon the high seas, no more helpless individual, than the man utterly unfamiliar with rod and reel trying to land a big game fish; he does not realize it, but the fish is having all the sport. I once came upon a Frenchman, off the bay of Avalon, who hailed me; and when we went alongside he was clinging desperately to a very pliable impossible bamboo rod, his back 
bent into a bow, and on his knees, holding on to a tuna which was somewhere down in the deep channel. The fisherman's face was red, the veins stood out upon it like cords, and perspiration rained down. " $Z$ e man who invented zis tunare fishing, he ought to be in zee jail," he cried. "Come and take me off heem, will you? For hours I have heem; he take my fingare nail, he take my skin; he take me next. $Z$ is is not fishing, zis is Hades."

The Frenchman would not allow his boatman to interfere, as he thought he had a record fish, and he had been trying for hours to reel it in; when it did come up, through the efforts of my boatman and myself, and was found to weigh but eighty pounds, the woe and rage of that Frenchman passed all understanding.

The angler at Aransas Pass will find the custom holds of towing the fish to the beach - a most laborious habit and unnecessary if the boatman has a large wide-beamed boat, when the largest tarpon can be held at the rail, the hook dislodged, or the game killed and taken aboard with ease by a boatman who understands his business. A green hand, or a nervous man, should be avoided, as such an one will lose his 
head at a difficult gaffing and strike at or down upon a fish, and so cut the line - a crime of sinister character, for which the code provides no adequate punishment, especially after a fish has been played for several hours.

One of the charms of tarpon, as well as tuna, angling is that it is preëminently a social pastime. Often fifteen or twenty boats are grouped within hailing or signalling distance, and the man who has no strikes is regaled with the vaulting fish of more fortunate anglers, and the sight of four or five tarpons in the air at once is a most exhilarating scene; yet Byron in "Don Juan" refers to angling as a solitary vice.

"... angling, too, that solitary vice,

Whatever Izaak Walton sings or says;

The quaint, old, cruel coxcomb, in his gullet

Should have a hook, and a small trout to pull it."

There were many delights which did not enter the soul of the great poet, almost the only man of distinction to denounce angling. Yet we may pardon him, as he appears to except the tuna and would probably commend the tarpon had he known this noble fish. His honest dislike for angling is well worth quoting, and in a note to 
the condemning lines in "Don Juan" he writes: "It would have taught him humanity at least. This sentimental savage, whom it is a mode to quote (amongst the novelists) to show their sympathy for innocent sports and old songs, teaches us how to sew up frogs and break their legs, by way of experiment, in addition to the art of angling - the cruelest, the coldest, and stupidest of pretended sports. They may talk about the beauties of nature, but the angler merely thinks of the dish of fish; he has no leisure to take his eyes off from the streams, and a single bite is worth, to him, more than all the scenery around. Besides, some fish bite on a rainy day. The whale, the shark, and the tunny fishing have somewhat of noble and perilous in them; even net fishing, trawling, etc., are more humane and useful - but angling! No angler can be a good man." After writing this Byron appears to have recalled the fact that he had a friend addicted to angling, and we find the following: "One of the best men I ever knew-as humane, delicateminded, generous, and excellent a creature as any in the world, was an angler. True, he angled with painted flies, and would have been incapable of the extravagance of I. Walton." In a 
third note he explains that "The above addition was made by a friend in reading over the Ms. Audi alteram partem - I leave it to counterbalance my own observation."

In tarpon angling when there are many boats in a small area there holds an unwritten code of courtesies which, indeed, applies to all fishing, and which may be mentioned. Thus it is the rule not to anchor near another boat unless requested. When a fish is hooked, other anglers should give the player the field. When two men are fishing in the same boat the other should reel in at once. To cross the line or foul that of a fellow-angler is a gross discourtesy, and it is equally criminal to talk to a man playing a fish, either to gibe or congratulate. Social amenities find no place at this strenuous moment. It is well not to borrow bait or tackle on the ground, as the average angler will gladly respond, and it has happened that the fishing days of two, instead of one, have been spoiled by the negligence of one boatman to secure bait; a boat should not put out without an abundance of bait and a perfect equipment. It need not be said that these suggestions are advanced to a wouldbe angler or novice. Nowhere in the world of 
sport is found a warmer fellow-feeling, greater hospitality, and more courteous camaraderie than among the gentlemen of the rod on the great fishing-grounds of America.

To Dr. H. W. Howe of the city of Mexico and Mr. J. A. L. Waddell of Kansas City, anglers are indebted for information regarding the midwinter tarpon fishing at Tampico, Mexico, an unsigned and interesting paper on the subject appearing in Modern Mexico in May, Igo I, to which I am indebted for the data herewith given. Dr. Howe wrote me that he has hooked several tarpons here which he could not handle; hence, the tarpons of Tampico are of large size. The season is from November I to April, the time when the tarpon practically disappears from Florida and Texas. The tarpons are not only very large but are found in vast numbers. Some mornings during his visits there could be seen hundreds of fishes within fifteen minutes by boat from the hotel. Mr. Waddell in eleven days in December at Tampico landed twenty-four tarpons, fifty-nine jack-fish, and two jewfish, weighing in all thirtyfive hundred pounds; the largest tarpon measured six feet ten inches. In March he landed six tarpons here in one day. Mr. A. B. Ross in 
six hours caught four tarpons. In the Forest and Stream of July 26, 1902, Mr. Waddell gives in detail much interesting data relating to the fishing here, and states that the Tampico tarpons "strike more voraciously than do those at Aransas, and I believe they fight harder and jump higher. One that I had on this last trip jumped fully twelve feet."

From this it appears that Tampico is a profitable field for the wandering angler during the winter season in the United States, and as thirteen of Mr. Waddell's fish averaged six feet in length, they do not lack in this important particular. Aside from good sport at Tampico the angler will find attractive surroundings. Tampico is a typical Mexican city of twenty-five thousand inhabitants. It stands on a bluff, overlooking the Panuco River, at which point this fine stream is fifteen hundred yards wide. The river enters the Gulf at Point La Barra, about five miles from Tampico, where there are fine jetties. The fish are found at their best from the mouth of the river to the city and where the Tamesi flows into the Panuco. The fishing-grounds are protected from the ocean here, and ideal conditions found. The winter climate of Tampico is described as being "all that could 
be desired, being neither warm nor cold." The tarpon season is not the rainy season, hence the visitor will find healthful conditions and, to quote the language of Modern Mexico, the climate during the season described is "delightful." Anglers proposing to visit Tampico should take their own tackle, and doubtless more definite information may be obtained by addressing the officials or consuls stationed there. 


\section{CHAPTER XVII}

\section{THE BLACKFISH}

"When chestnut leaves are as big as thumb nails, Then bite blackfish without fail,

But when chestnut leaves are as large as a span, Then catch blackfish if you can!"

THE blackfish, tautog, Tautoga onitis, is rarely referred to as a game fish, yet few members of the finny tribe, at least in New England waters and in Long Island Sound, afford so much pleasure to so many people. The tautog is omnipresent, and the angler catches the smaller members of the tribe whether or no; and when the water is fairly shallow and the fish run large, up to ten and fifteen pounds, the blackfish, if it is approached with light tackle, will surprise the angler. Such a location and such fish I found at Fisher's Island, Long Island Sound, and similar localities are known all alongshore. While the blackfish is in America a very democratic, not to say plebeian, crea- 
ture, it is of aristocratic lineage. The scarus of Europe is its foreign representative, and the ancient Romans gave it many high-sounding names, one of which was Cerebrum Jovis Supremi. Aristotle claimed that it slept. $\mathrm{He}$ wrote:-

"Scarus alone their folded eyelids close

In grateful intervals of soft repose

In some sequestered cell, removed from sight

They doze away the dangers of the night."

Pliny repeats this interesting statement, adding that it is the chief of all fishes. Ovid and Oppian sang its praises in verse, while Ælian claimed for it a surpassing love for its young. Elipertius expended vast sums in securing the fish for the wealthy epicures of Rome. Martial was so fond of it that he described it in verse, while Xenocrates writes of the viscera of the scarus brought directly from the sea. His favorite dish was the liver, which, with the milt of murries, the brains of peacocks and pheasants, and the tongues of flamingoes, was served under the high-sounding title of "The shield of Minerva," given it by Vitellius, the famous epicure. At a Roman dinner it was the custom to exhibit the living scarus to the 
guests, that they might be assured that it was fresh and directly from the sea. To-day the American scarus, the tautog, is disposed of in a few words - it is an excellent "chowder fish."

I have had rare sport with this fish at the Long Island Sound locality referred to. It makes a hard fight, though the greatest difficulty generally was to keep the bait intact until a large fish took it, so insistent were the small fish and their cousins, the "cunners" and "nippers." The tautog is taken at Cape Ann, and alongshore to Chesapeake Bay, where I have seen it at Old Point, and doubtless it ranges farther south, specimens having been carried to Charleston, South Carolina, in the well of a smack; but it is not found in great quantities. Around Newport it spawns as early as April, and from then on until August. I have heard from fishermen of blackfish weighing forty pounds, but a fifteenpound fish was very rare in my fishing experiences all along the coast. G. Brown Goode gives, as the largest specimen known, a blackfish which weighed twenty-two and a half pounds. This was three feet in length, and is in the collection of the National Museum. I have had fair sport with this fish from the 
rocks with a rod, off Salem, Massachusetts; and all alongshore, wherever rocky bottom and fairly deep water are found, and the conditions and bait are right, this sport may be enjoyed.

While the pollack does not come within the proper scope or range of this volume, and is not a large fish, I found it as gamy as a trout at Ogunquit, Maine. Casting from the rocks, I took them with a green fly, as well as bait; and several tips of my black bass split bamboo paid the penalty before I gauged the power of this active fish, not as well known or appreciated as it should be.

There is another blackfish, at least so called, in the waters about Martha's Vineyard, the sea-bass, Centropristes striatus, an entirely different fish. It belongs to the family Serranidæ, in which is included the splendid striped bass, which attains a weight of one hundred pounds, and affords rare sport off the islands of southern Massachusetts and in various localities, and since its introduction bidding fair to become the famous game fish of the San Francisco region. There are two species of sea-bass, ranging from Cape Ann to Texas, the northern species being found north of the latitude of Hatteras. The southern species is common at Cedar Keys, St. Marks, and other 
Gulf coast localities, but I never caught it out on the reef. It is a bottom fish, and yet affords many people a vast amount of sport in rod fishing of a peculiar kind well known to New Yorkers. One may read in the local press advertisements of certain steamers which in the summer months go daily to the fishing-banks outside of Sandy Hook. These banks range from the Highlands to Long Branch and beyond, the Cholera Banks being an exceptionally popular ground about twenty miles east of Sandy Hook. Going aboard one of these vessels, the angler finds an array of very short and clublike rods with heavy reels, stout lines provided with heavy sinkers, and abundance of clam or fish bait. Once on the ground, the steamer is anchored, rods are taken in hand, and the extraordinary sight witnessed of several hundred men fishing with rod and reel in deep water. The fish bite well, and the sport begins, sea-bass from four to seven pounds often being the largest catch.

There are a number of little-known fishes of the ocean which, if the angler could divest himself of certain prejudices, would be entitled to come under the term "game." Thus in Southern Californian waters the halibut of large size is often 
taken in shallow water, affording sport of an exciting nature. I have often seen the clumsy fish charging schools of sardines with all the zeal of a bass.

If sharks were to be included among the game fishes, some remarkable tales might be told of experiences between Florida and California; but probably Mr. Edwin vom Hofe holds the record in this field of sport, having taken a six-hundredpound saw-fish with a tarpon rod and line. Such catches with rods suggest an enumeration of strange creatures hooked while fishing for true game. While fishing for the eastern horse-mackerel off Boon Island, north of the Isles of Shoals, I hooked a sunfish (Mola), but it was accidental. On the Florida reef while trolling for barracuda I once caught a small hawk's-bill turtle. In Avalon Bay I hooked a sea-lion, which took my bait, and I played the large animal for several moments. I thought I could bring it to the boat, but the sea-lion evidently disagreed with me and brought the proceedings to a close by darting among some boats and breaking the line on an anchor rope. Few swimmers even can make headway against a man with a light rod and line. Other catches in California, which are often made by 
yellowtail anglers, are gulls and cormorants, and one fisherman distinguished himself by hooking a sea-eagle. Another played a young blackfish, which must have weighed half a ton, a second or two, while another angler's hook when trolling caught in the back of a fifty-foot California gray whale,-illustrating the variety that comes into the life of the rod fisherman in many seas. 


\section{CHAPTER XVIII}

\section{THE KINGFISH}

"By the way, old Cotton's instructions, by which I hoped to qualify myself for the gentle society of anglers, are not worth a farthing for this meridian." - Redgauntlet.

THE deadly monotony of a "dead calm" in the tropics can be appreciated only by those who have sailed the seas south of the tropic of Cancer where the sun's humor is fierce and uncompromising, and the wind god passes his summer days in a long siesta. Our trim craft, that could show her heels to any vessel on the reef, had literally been caught napping. The wind had gradually dropped until we floated on a sea of glass, the only motion on its surface being the long swell, the remnant of some recent gale, which served to swing the booms from side to side, - their jaws uttering weird moans, shrieks, and wailings, as they gripped the dry masts, which did not add to the pleasantness of the situation. The heat was pitiless, and the water pouring over the decks out 
through the scuppers did not even harden the tar which oozed up from every seam.

For twenty-four hours we drifted, the clear rich blue of the Gulf Stream offering every invitation; but the dusky shapes of a number of "maneaters" barred even this solace. It was while thus adrift, thirty miles east of East Key, that Paublo bethought him of a wind-raiser, and forthwith taking a belaying-pin, hammered vigorously on the foremast. I learned later that this was generally infallible; this day it failed, failed to raise the wind, but as the captain of the galley and clever boatman replaced the pin, the smooth water of the Gulf broke into foam not two hundred yards away: he had "conjured " up the kingfish. The dinghy was drifting astern, and it took but a moment to grasp rod and tumble in. Under Paublo's strong strokes we were presently in the heart of the school from which I took my first kingfish. The rod was so well fitted for the work that I can but commend it. It was of greenheart, eight feet in length, of two joints, and weighed about twenty ounces. The line was a fine linen, number twelve cuttyhunk - a mere thread to be broken at the slightest mistake; the hook, a 6/o Limerick, with a long copper wire 
leader of home make. The bait was a "sliver" of the belly of a salt kingfish, about four inches long; and as I overreeled and paid out, this ancient dainty was seized not fifteen feet from the boat, and about one hundred feet of line taken with a single rush. How the steel click told the story in metallic shrieks! finally settling down into a spasmodic zip-zip-zip! as the fish was checked by the brake. Like the bonito it played upon the surface not five feet under; now on the top, making side rushes; now circling the boat, bearing off until the rod bent to the danger point and the delicate line hummed a music of its own; and anon going into the air in splendid leaps. For five or six minutes, due perhaps to the exigencies of the situation, the lightness of the tackle, the kingfish played me, jerked my arms down, to release them as suddenly, shook its powerful tail at me in derision, plunging through a fleet of Portuguese men-of-war or cutting through the chalice-like form of some dainty jellyfish deeper down, but almost always on the surface, and moving so rapidly that the boatman was ever on the alert to keep the light boat stern to the game. The water was alive with fish of the largest size feeding on a vagrant 
school of small fry, and there was constant fear that the taut line would be cut by the dorsal fin of some fish.

Two hundred feet of line was forced, coaxed, torn from the reel, before I really stopped this roistering plunger, and then it was give and take, a long battle in which the banner changed sides more than once; the fish making a splendid display of its game and fighting qualities, which, to me at least, are utterly lost when the fish is taken with a hand-line after a fast-sailing boat, the typical method, due, perhaps to the fact that the kingfish is found in the open sea or where the water is more likely to be rough. Slowly it came in, leaving silvery flashes against the deep blue of the Gulf, fighting every inch until the gaff struck it and Paublo lifted it, quivering, upward, his eyes standing out in amazement at the size of the fish and the mysterious power of the rod and threadlike line.

"Why, mawster," he said, "while you workin' datcher wheel I could wif a cast-line [hand] ketch fo' or five kingfish."

It was our first day's fishing, and I suspect that Paublo thought that I "did not have all that belonged to my upper works," as the Conchs ex- 


\section{The Kingfish}

pressed it; but I lived to see him a derisive mocker of his compatriots, who "jerked in" game fish with a ropelike line, or did not give the game a more than fighting chance for its life.

The fish which Paublo held up in the sunlight for my inspection was one of the two or three fishes which the wreckers and fishermen along the outer reef called "king." It was between five and six feet long; as it was held up its tail rested on the boat and its head was even with Paublo's eyes, a splendid creature which we "guessed" at forty pounds, a long, slender barracuda-like fish of the mackerel type, a privateer, rakish, gamy in appearance, fitted for swift rushes and strenuous work among the small fry. The dorsals were two in number, the first low and extending from the base of the pectoral to nearly opposite the front fin of the anal, the upper portion colored almost black. The second dorsal was higher, with a jaunty effect; then followed eight finlets resembling those of the tuna; the tail was large, forked, and powerful. The sides of the fish gleamed like burnished silver; its back was dark blue, while across its sides pronounced black longitudinal stripes extended, represented above and below by dark spots, giving the fish a peculiarly attractive 


\section{Big Game Fisbes}

appearance. The eye was large, bright, and beautiful. Such was the kingfish, or spotted cero, Scomberomorus regalis, which later it was my good luck to catch all along the reef from Key West westward.

The fish attains a much larger size than generally supposed, and I am confident that I hooked specimens on the borders of the reef to the east of Garden Key which would have tipped the scales at over seventy pounds; yet it is well to bear in mind that it is the largest fish that invariably escapes. At all sizes this fish is a gamy catch, the small specimens making excellent play, while the large ones are game, always hard fighters. The fish is fairly common on the extreme outer Florida reef, increasing in numbers as one goes to the south toward Cuba.

The second kingfish, and the best known in our own waters, especially in the region between Key West and Biscayne Bay, is the cero, Scomberomorus cavalla. It has a striking resemblance to the former, but can be recognized by the angler at once by the absence of the spots or bands, its gray color, and by the lateral line which takes a sudden dip just below the second dorsal fin. This species is the fish of the people, the 


\section{The Kingfisb}

common catch offshore, ranging from Brazil to Massachusetts, but most plentiful in the region from Key West to Cape Florida. I have seen the water ploughed into foam by it in the open Gulf, and it is as gamy as its cousin. I never heard the name cero used by any men on the outer reef in connection with either of these fishes; all called them "kingfish." To the professional fisherman it is exceedingly valuable, and is caught in great numbers in the vicinity of Key West. In all the Gulf states about 400,000 pounds are taken annually, valued at $\$ 6000$. I often took it down the reef, off Sand, East, and Bird keys, where it came in near the great fringing reef that was submerged at high tide. The water here was perhaps fifteen or twenty feet deep, with a bottom of coral heads, plumes, and sponges, washed by the grand swell, and being on the edge of the Gulf Stream or in its very midst, seemed to offer the exhilarating conditions demanded by this active creature, which by trolling could almost always be taken here. The adults ran from fifteen to thirty or forty pounds, and there were legends of colossi which weighed up to one hundred pounds, but I never saw them. The young, from six to twelve pounds, were very gamy with light rods, calling to mind 
bonito, which in my experience is a surface fighter. I baited usually with young mullet, but the kingfish stands not upon the order of bait, but takes what is offered with a rush. I have caught them with rags white, rags red, and rags yellow; with a bone jig, with a piece of elongated conch, and a home-made spoon cut and filed from the tip of the big Strombus gigas, this by casting and reeling quickly. For a fish so extremely common very little is known regarding its habits. Specimens which I caught in the open water near Key West in December contained spawn, but I never saw a very small or young fish in the outer bays or reef. Smack fishermen state that they spawn in the shallow waters around Biscayne Bay. The professional fishermen of Key West have a hearty appreciation of the kingfish, which they follow in large and small boats, trolling for them in deep water, or on shallow grounds offshore, as the case may be, often literally filling the boat with the ceros which rank high as table fish.

A feast of the kingfish which I often attended is an experience long to be remembered. It would often be announced by the laughing gulls, whose loud and resonant "ha-ha" would come over the glasslike waters as the bird rapidly increased its 
speed. Others, recognizing the summons, joined it, and out from all portions of the reef came birds - the lumbering pelican, and last the man-of-war bird. What had been at first a few splashes was now a mass of foam, which, surrounded by smooth water in the heart of a dead calm, presented a strange appearance. The ocean seemed to be boiling, the patch of several acres moving slowly along. Once in this magic area, countless fishes were seen dashing along the surface, chasing a school of small fry. Long ago mere hunger had been appeased, and the kingfishes were slaughtering their subjects for the mere pleasure of killing. The foam was tinged with red, and from it, sinking into the sea, would be seen a shower of silver, the severed bodies of the victims attracting sharks and other prey.

Resembling the kingfish in many respects is the Spanish mackerel, Scomberomorus maculatus, a game fish in every sense, coming from southern and unknown seas in spring in vast numbers in search of food - menhaden and other small fry and to spawn. I have taken large specimens trolling to the east of Fortress Monroe near the capes, where large schools come in, and once ran through a school in the Florida Straits, which 
seemed to cover the ocean as far as the eye could reach. In the Gulf they were common, a few individuals being seen at all times in deep water around Garden Key in the Tortugas group. Here they frequently made splendid displays, beating the water much like the jack, only in deep water, never running in upon the beach. The sound of their feeding was like the roar of a heavy tide-rip, caused by the fishes dashing hither and yon into the air and back. At such a time I have run through a school with a sail-boat, the sport being comparable to bluefishing, a white rag being used. But the most satisfactory sport was to cast into the school from the outer edge. The fish played like the bonito, making no effort to sound, dashing around a fish of ten or fifteen pounds, towing a dinghy about as though on a pivot. If the Spanish mackerel could always be found, it would soon take its place as a fine game fish and be eagerly sought by the angler; but its movements are erratic, and often, when located, it will not bite. Such, however, is the masterly play of the fish that the angler who takes it once will return invariably to the often elusive search.

I found the Spanish mackerel fishing excellent at Aransas Pass, and every morning in August 


\section{The Kingfish}

during my visit a small fleet of boats would gather in the narrow pass and fish. Those who fished as a business had long bamboo poles which they kept moving up and down, landing a mackerel of small size every few minutes. I used a light blackbass rod, and baiting with shrimp, caught by a boy with a cast-net, enjoyed the sport, taking fishes from three to seven pounds; but the man with the fifteen-foot bamboo, with a short line tied to it, beat me ten to one, and gazed at my light tackle as the armament of a tenderfoot. While fishing here several skipjacks and a three-pound "tenpounder" jumped into my boat at intervals of ten minutes; then an alligator gar rose alongside apparently anxious to emulate the small fry, while a speckled sting-ray hovered for a moment in the air like a bird, astern. These and schools of mullets, constantly leaping in silvery waves on all sides in the shallows, gave the impression that all the fishes in this peaceful region were jumpers; and there was consolation in the thought that if the fish did not bite, they might at least jump aboard, which was much the same thing if dinner, as well as sport, was to be considered. I have seen the Spanish mackerel in many waters, but these Texas fishes, with their black and vivid yellow or golden 
spots, seemed more beautiful than any I had previously caught; and when my professional companion came ashore with sixty to salt down, the homely boat fairly glowed with the golden glint reflected from the brilliant throng.

The Spanish mackerel has a wide range from Brazil to Gloucester and on the Pacific Coast of America, everywhere held in high esteem as the finest of table fishes. It is usually caught by trolling, and is essentially a surface fish. Its schedule of migration may be considered as follows: It arrives off the western Florida coast in March and reaches North Carolina about the same time. In May I have taken them off the rip-raps, at the entrance to the Chesapeake, and large quantities are taken on the Eastern shores. The movement is northward, and by July they appear in the waters about New York, moving slowly up the coast, everywhere in demand. Mr. Earll states in his exhaustive monograph on this fish that it spawns near Sandy Hook, in Chesapeake Bay, and in Pamlico Sound, beginning in April in the latter and ending in August in the former. The eggs of a six-pound fish he estimates equal 1,500,000. As soon as cool weather approaches in the fall the Spanish mackerel moves, and by October it has 


\section{The Kingfish}

disappeared from the North, probably seeking warmer waters farther south.

In appearance the Spanish mackerel is very beautiful, especially when taken from the water. The upper portion is a deep, steely blue, the lower, silver, while over all is a sheen of delicate pinkish iridescence. On the sides are orange-colored spots. The dorsal fins are tinted black, white, and yellow, seemingly blended to increase its beauties. So far as its economic value is concerned, it ranks second to none, the fisheries being extremely valuable, amounting annually to about 2,000,000 pounds, valued at about $\$ 75,000$. The largest number are taken in pound and gill-nets.

The bonito, Sarda chiliensis, is, in my estimation, one of the gamiest fishes taken with a light rod on the California coast. It is the hummingbird of the sea, no description or word-painting being adequate to describe its beauties. An eightor ten-ounce split bamboo, with very light line baited with a two-inch sardine or smelt, or several anchovies, is the lure most telling at Santa Catalina. I anchored one day in a little bay not far from the isthmus and went ashore, giving instructions to the boatman to "chum" while we were at lunch. Half an hour later a signal came telling that the 
game had arrived. When I reached the launch the water appeared to be alive with forms dashing about with great velocity. When a handful of sardines was tossed over they charged them from the channel a few feet away, picking them up with great rapidity, then disappearing. Almost the moment a cast was made, almost before the bait was set in motion by the reel, the strike came, and a blaze of color dashed along the surface to the music of the click. Always on the surface, - no sulking here, - darting this way and that, in and out around the launch, this bonito, the skipjack of the sailors, was the peer of any trout in the world, and only after a struggle was it brought in; and then one could but regret the capture of so beautiful a fish. It was robed in silver satin below, merging into vivid blue above, with dusky stripes, and over all, flashing and scintillating, an iridescence in pink, blue, and yellow, which made it one of the most charming of the finny dwellers of the Californian sea. The bonito is short and very plump, and when lifted by the gaff or net (the latter is to be preferred, as the fish bleeds badly) it quivers so violently as to impart a disagreeable sensation to one who attempts to hold it by the tail. 


\section{The Kingfish}

The season for bonitos, on the California coast, is from May until December, the midsummer months being the best. The largest fish I have seen weighed twenty pounds, and was so powerful that it repeatedly towed the heavy boat around and around, making a more desperate fight than some fishes I have taken, of twice the size. The average size of the bonito in these waters is twelve pounds. The range of this species is very wide, covering all the Pacific from San Francisco to Chili, beyond and west to the shores of Japan. It doubtless spawns in the open Santa Catalina channel and in the vicinity of the islands; but extremely young fishes have never been observed here by me, though I have dredged and watched the hauling of seines and nets, surface and otherwise. This region is a spawning-ground for many genera. The flying-fish spawns here in July, yet I have never been able to secure a young one, though I confess to have chased them, about the size of grasshoppers, for hours with a scoop-net. The little creatures, about an inch in length, could "fly" or soar about a foot, and attempted to take to the air as I struck at them with the net. They well illustrated the ease with which the young of common fishes can escape obser- 
vation. The bonito is eaten on the California coast, but the flesh is coarse and very different from that of the delicious Spanish mackerel. It is well to remember, however, that there is only one cook in a thousand who understands how to cook a fish. In point of fact, every fish is a gastronomic study by itself; some should be eaten immediately after the catch, and this is particularly true of the mackerel tribe, - always excepting the salt mackerel of Marc Antony, which, we are assured by Plutarch, constitutes the theme for his true fish story, involving the caprice of Cleopatra. How many anglers have played this same joke on an unsuspecting friend! And lest there be some son of Ananias who claims it as new, the story may be recalled. It seems that Antony and Cleopatra, according to veracious Plutarch, were fishing, probably in the Nile; and wishing to make the noble Antony a victim to her wit, she instructed a slave to slip over and dive down and fasten upon his hook a dried salt fish, supposed to be a mackerel. The slave obeyed, and when the act was accomplished, gave the line a vigorous jerk, holding on while Antony tugged and played, until the slave lost his breath, then landed the salted and ancient fish. At this point the 


\section{The Kingfish}

victim, at least to-day, is the butt of gibes and laughter; but not so with Marc Antony. He held up his catch proudly that his mistress might look upon its charms, then said to an attendant: "Unhook it. True, it is not so large as I conceived by the play it made, but it is by far the oldest fish taken to-day." 


\section{CHAPTER XIX}

\section{THE FLORIDA JEWFISH}

"In gulfs enchanted where the siren sings, And coral reefs lie bare."

IT requires more than ordinary temerity to include the huge Florida jewfish among the game fishes, as the average individual is the type of all that is indifferent, a lazy, heavy "beastie," a finny Falstaff, the colossus of the nooks and corners of the reef. Yet several jewfishes which I have met have made a game struggle, and all afforded sport. On the coasts of Texas and Florida the fish is occasionally taken with rod and reel in true sportsmanlike fashion.

My first experience with the jewfish was in the vicinity of Marquesas, on the edge of a deep blue channel which blazed its way through the reef like a rope of turquoise. We had seen several so-called tiger-sharks with dark bars athwart their tawny flanks, and Paublo, the dusky boatman, had aroused my curiosity in this tiger of the sea by 298 
various incidents more or less racy, dragged, I fear, from the deep, unfathomable recesses of his imagination. One story apparently was true. A tiger-shark had leaped after a swimmer climbing aboard a yacht and had carried him down. The shark was plainly seen moving about, eight or ten feet away, doubtless awaiting the rejectamenta of the culinary department. I baited with a live yellowtail, as dainty and alluring a threepound fish as could be found on the reef, and almost before it had reached the bottom, the line stiffened out in a steady strain - in my experience the typical strike of the shark. I waited for the line to run out, but the shark evidently was peacefully swallowing the bait; then I saw it rising out of the depths dimly against the blue, and thinking that it was coming to the surface, struck with all my strength. No shark, nearly every kind of which I have caught, ever hurled back so sturdy a defiance. It was irresistible, and the line tore through the water with the peculiar hissing sound which carries a fascination with it. Fifty yards clear away the fish dashed, before it could be stopped, and all this time the tiger-shark was slowly rising, plainly not a party to the proceedings. I was in a light dinghy, my man cast 
off and at once we were rushing away, bow under, in a manner so sharklike that $I$ was convinced that the tiger-shark had a mate and we had hooked it; but this conclusion was dispelled by the sudden slacking of the line.

"Ole jewfish, sa', an' he done tuck to his hole!" cried Paublo, as the little boat came to a standstill.

Paublo was a true prophet, and investigation showed that the fish, in all probability, had run beneath a deep ledge of branch coral, and any attempts to lift it would result in chafing off the line; so we decided to "kedge off" the game. The dinghy was rowed into the channel three hundred feet or so, and while Paublo rowed vigorously, I hauled, with the result that the fish was forced from beneath its shelter, and after taking it in two hundred feet, it made a gamy rush around the dinghy. Owing to the length of line I was able to hold the fish, while Paublo pulled for deep water, where we held it before it sounded. Despite a piece of canvas as an improvised brake, I could not stop the fish; and only finally succeeded by lying flat back in the bottom and bearing on with the big line in the scull hole; I thought for a moment that the fish would take 
the dinghy under, so forcible were its downward lunges. For several minutes it plunged and sounded, then I passed the slack to Paublo, who, as I hauled, coiled the line, making everything shipshape for a big rush which might be expected. But the hand-line tactics were too much for the game, and I steadily gained, not without punishment, as the fish would ever and anon literally shake its head, giving such sturdy, dislocating blows that my arms ached again. Finally it neared the surface and Paublo leaned to windward that I might glance over and see the game that was putting up so desperate a fight. As I looked down, not twenty feet in the clear water, I saw my first jewfish, apparently as large as the dinghy, a colossus in black, with here and there a flash of a lighter tawny tint as it rolled and essayed to plunge. It must have seen me, as it made an upward rush, then around, whirling the dinghy as though on a pivot, so that she careened viciously. This was the last. I gave Paublo the word, and as he backed water rapidly, I soon had the big game at short quarters, and its mighty head triced up at the surface astern, while a short distance away the tiger-shark swam lazily about, its tall dorsal cutting the water. As 
the jewfish rolled from side to side, occasionally pounding the water with its powerful tail, it was a remarkable spectacle. Its length, as near as I could judge, was over six feet; its color a brownish olive with lighter spots, lighter upon the belly. The head seemed enormous, the eyes small and perched high up, and far down near the nostrils; the lower jaw projected slightly; the gill-covers were large. Perhaps the most noticeable feature was the rounded tail, which is the antipodes of that of the huge Stereolepis of the Pacific coast, with which it is often confused by anglers who apply the name jewfish to both. The bulk of the fish was overpowering, and what it weighed was a matter of conjecture. Those who saw it, estimated its weight at between five and six hundred pounds, Paublo being ready to make affidavit that it was an eight-hundred-pounder; but while there seemed to be no limit to its vastness, I think it would be safe to place it at three hundred pounds. Later I saw a jewfish on the beach at Conchtown, Key West, which, it was said, weighed six hundred and forty-two pounds. The fish attains a weight of over one thousand pounds and fully meets the estimates placed upon it by boatmen, whose imaginations are limited by no slavish bonds. 




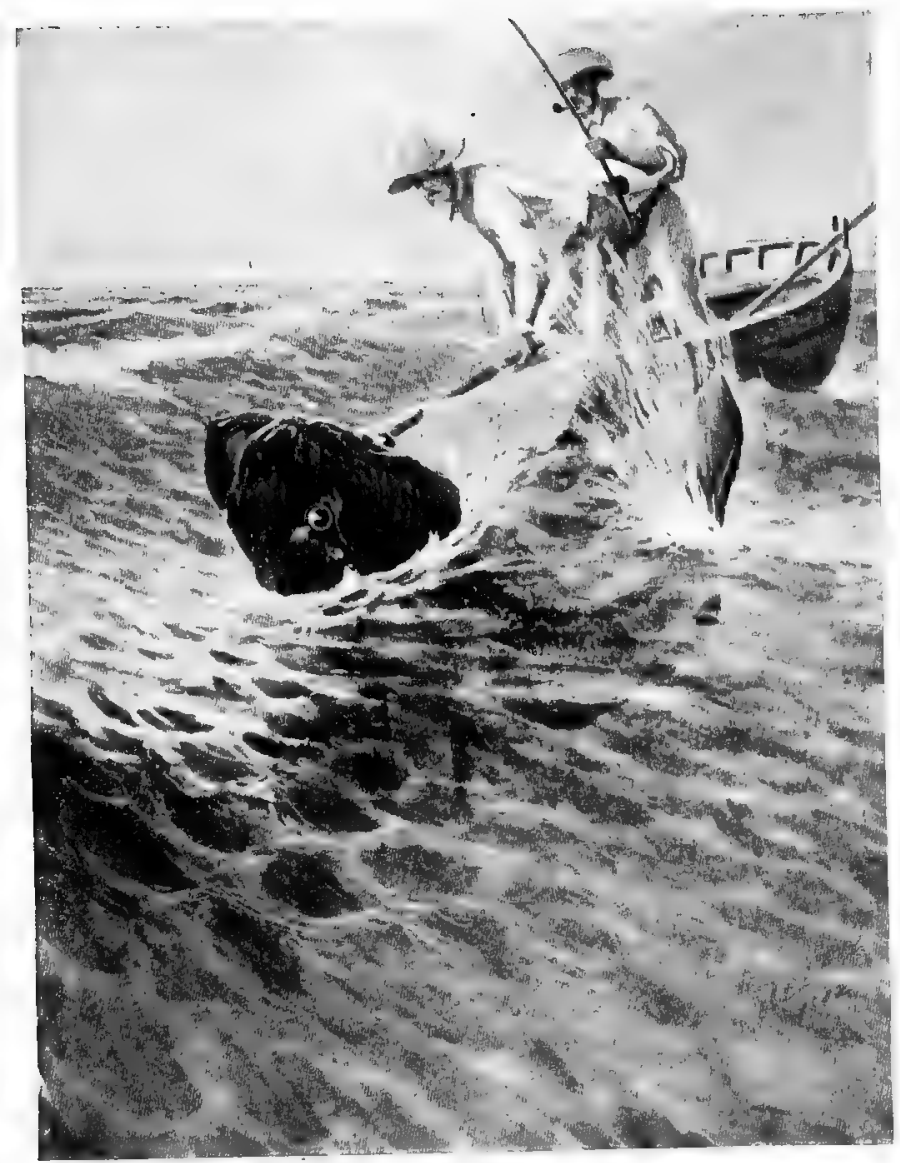



Our struggle with the jewfish attracted the attention of the skipper of a smack, and as I was about to cast off the fish, he hailed and asked for it. We towed it alongside while he ran up in the wind, then a barbless hook was inserted in its jaw, the crew manned the halyard, and the jewfish was hauled aboard. The skipper, who hailed from Mystic, quickly took a few stitches in its mouth to prevent it from eating the rest of his catch, then the fish was lowered into the well and later carried to Havana, where jewfish steaks were highly esteemed.

Within thirty miles of this place I caught a number of jewfishes, several giving me exciting contests before subdued. One taken in shallow water fought in a lagoon for three-quarters of an hour before it was landed. The tackle employed for this fish was an ordinary halibut line with a doubled leader six feet long, and a very large hook; the bait was hooked through the fish just under the dorsal fin, near the tail, so that it was practically uninjured; a small sinker was used to carry it down.

There are two genera called jewfish by the habitués of the reef: the black grouper, when of large size, and the "Warsaw," Promicrops itaiara. 
Not a few anglers profess to believe the two fishes identical, the huge Warsaw being the adult black grouper; but the consensus of opinion is against this, and the two adult fishes side by side certainly could not be confused. The jewfish proper, Promicrops, is found from Brazil to Georgia, possibly rarely straying farther north, and in the Gulf of California. I was assured that the fish was common at the mouth of the St. Johns River, Florida, but in three months' fishing there and at Fernandina I saw none, though it is fair to say that sharks were so plentiful at the time that they seriously interfered in the quest. The fish is fairly common at Garden Key; also on the Gulf coast of Florida, - in fact, the entire Gulf coast, where it appears to haunt the bayous, preferring "holes" and localities affected by the grouper, in comparatively shallow water. At Aransas Pass, Texas, and vicinity, the fishes of the largest size are taken by sportsmen with rod and reel.

Some exciting fishing for jewfish may be had at the town of Tarpon, Aransas Pass, where the fish attains an enormous size, and at certain times is found in what are apparently schools. In November they come in, or "run," for several days, by the Point of Rocks, and are fished for from 
the beach or near it. In 1902 the anglers at Tarpon had some remarkable fishing. Six huge fishes were taken in a day, and sixteen in two days, one of which, caught by Mr. J. A. L. Waddell, with Robert Farley as boatman, weighed four hundred and fifty pounds, and was claimed by the angler as the record jewfish of the world with rod and reel. This does not conflict with the Pacific coast record of Dr. H. T. Kendall, as the two fishes are generically different. Mr. Waddell's fish was a jewfish (Promicrops), that of Dr. Kendall, a black sea-bass (Stereolepis). The Texas record fish made a most gamy fight and redeemed the tribe. It measured seven feet three inches in length, its girth being five feet nine inches-a veritable colossus. According to the old fishing formula given elsewhere the fish weighed five hundred and eighteen pounds, sixty-eight pounds more than the actual scale weight of the fish, two days later. The largest jewfish landed in these waters was taken by some seiners at Corpus Christi Pass, Texas, several years ago. It weighed one thousand and fifteen pounds, suggestive that there is a field for the lover of such big game in these haunts of the tarpon. When in comparatively shallow water 
the great fish can be counted on to make a gallant play.

The equipment for this strenuous sport is a rod not over seven feet in length and of sufficient stiffness to lift the heaviest fish. The noib-wood tuna rod described is equal to the task by using a heavy tip. The line should be number twentyfour, the only difficulty being that the fish when taken in shallow water has a sorry habit of plunging into the equivalent of the "dark, unfathomed caves," where the best of lines often fails to dislodge it. Every sportsman fond of big game has a keen desire to kill an elephant. So, too, the big fish angler will be tempted to take a jewfish; and should it chance that they are all hard fighters, he may become enamoured of the sport. I rarely caught young jewfish and do not recall seeing one less than two hundred pounds in weight. They spawn in May, June, and July, and are found in the localities mentioned at all seasons of the year, but more frequently in spring and summer. It is believed that they retreat into deeper water in winter. It was not uncommon to take jewfishes from June to October on the edges of the lagoons or off the outer reef in water not over twenty feet in depth. They fed in the shallow lagoon at 


\section{The Florida Jewefisb}

night; but in the so-called winter months we sought them in the outer channels, hence the belief grew that they were slightly migratory.

On the mainland coast of Florida the jewfish can be found at Captiva, Palma, Sola, Charlotte Harbor, the Biscayne Bay country; and all alongshore, where there are sheltered nooks, where a channel runs in, and mangrove roots have rolled down the bank, forming a cheveaux de frise, are haunts to its fancy; but among the outer keys the fish is found along the base of deep coral groves. Such a home I well recall on the southern end of the great Tortugas lagoon so frequently changed by hurricane and storm. I had been in quest of the queen conch, - a rarity even in this prolific hunting-ground, - and was slowly drifting over the lagoon, eying the bottom through a glass observation box, when I suddenly came to the edge of the reef, where the coral began. The water was from twenty-five to thirty feet deep, now paved with luxuriant, long-pronged branch coral that, under the influence of the abundant food-supply, had developed to an amazing extent. It appeared to be five or more feet in height, surrounded by masses of lavender-tinted gorgonias and plumelike forms in rich browns, while dotting the bot- 
tom were great heads of coral, their surfaces sprinkled with the brilliant breathing organs of worms of all colors.

Poised in this garden were dainty yellowtails, parrot-fishes of lovely colors, angel-fishes, seaporcupines, and an endless train, - all courtiers of a huge jewfish which crouched or poised in a little bay, an enclosure of coral just large enough for it to enter and turn easily, the entrance being small and narrow. In this veritable bower, with asthetic objects of the sea on every side, the jewfish rested, only darting out as my boatman plunged over and swam downward, to rob the sea-fans of the yellow "fan" shells which clung to their reticulated sides.

The angler who does not care to go to the outer reef beyond Key West or to Texas, will find the fish all alongshore on the Indian River, the towns of Titusville, Cocoa, Eau Gallie, Fort Pierce, and others being centres for professional fishermen, now easily reached, while the west coast abounds in resorts from Cedar Keys south. Indeed, the entire region from Cedar Keys on one side and St. Augustine on the east coast to Loggerhead is an angler's paradise, winter or summer, abounding in the greatest variety of fishes. 


\section{CHAPTER XX}

THE DRUM

"His drumming heart cheers up his burning eye."

- Rape of Lucrece.

The good Bishop Paul Jovius, who flourished in $153 \mathrm{I}$, tells the following story, illustrative of the regard in which the epicures of olden times held a European representative of the drumfish.

In 1480 there lived in Rome a famous gourmand named Tamisio, who had a weakness for the maigre, the surmullet, and for murries drowned in wine. To such an extent did this passion carry Tamisio that it was his custom to station his servant in the fish-market to bring him intelligence of the destination of the finest fish. Learning, one evening, that a maigre of unusual size had been brought in, he instantly hurried to wait on the conservators, in expectation of an invitation to dinner; but as he ascended the steps of the capitol he met the head of the fish, adorned with flowers and borne, by order of the conserva- 
tors, as an offering to Cardinal Riario, nephew of Pope Sixtus IV. Tomasio, being well acquainted with this prelate, gladly joined the procession; but Riario, delighting in a play of words, said that the head of the greatest of fishes should by right go to the greatest of cardinals, and sent it accordingly to Cardinal St. Severin, who was of extraordinary bulk. St. Severin, in his turn, despatched it in a golden dish to the wealthy banker Chigi, to whom he owed money. This time Tomasio, in his eager pursuit, had to traverse the whole city and to cross the Tiber on his way to the Farnesian palace, which Chigi had built. Chigi, however, did not retain the much-prized head, but after replacing the faded garlands by newly gathered flowers, sent it to his mistress, whose abode lay a good way off. There Tamisio, who, though fat and unwieldy, had tracked the object of his desires, under a hot sun, over a whole city, was at length permitted to enjoy the luxury he had endured so much toil to obtain.

The persistence of Tamisio was a bagatelle compared to the journeys of modern anglers, who cross oceans and continents to take the fishes of their choice. The modern Tamisio is an angler, his object being to take a big sea-drum with light 
tackle. Its flesh is little appreciated, though it is fair to say that very few anglers know that the head of many fishes, invariably thrown away, is the bonne bouche.

The sea-drum is a very well-known fish, attracting attention by its ponderous size. It ranks next to the tuna, black sea-bass, Florida jewfish, black grouper, and tarpon in size among American game fishes, specimens having been taken which weighed over one hundred and fifty pounds; and fishes from forty to eighty pounds are not uncommon. In appearance the sea-drum is a large and attractive fish. The body is deep and oblong, rising in a decided "hump," the ventral outline being quite the reverse, so that when placed on the beach the lower surface of the fish will touch from the lower jaw to the tip of the tail. The dorsal fin is tall and prominent; the tail large and powerful, not forked; the anal fin long; the eye is large and striking, the head blunt. The teeth are small and arranged in bands; the pharyngeal bones provided with a crushing pavement, formed of blunt molar teeth, or "oyster crushers." The color of the fish is black or very dark in the adult, the young being silver gray with five or six vertical bands. On 
the under jaw are numerous short barbels. The range of the fish is from Long Island to Mexico, being almost everywhere a common fish, affording good sport to the angler.

The drum belongs to the family Scianida, which includes the weak fishes, the white sea-bass, and many others famous in European waters and among the ancients. The sea-drum, the object of our attention, is known to science as Pogonias cromis, but in various localities it has other common names. In some the striped young are considered separate fishes and called striped drums. On the extreme outer reef the men I fished with called it the "porgy," the drum being "big porgy" and the sheepshead "little porgy."

Its habits are similar to those of the sheepshead. It is a slow swimmer, frequenting shallow waters, preferring sandy bottom; affecting oyster-beds, or localities where it can obtain shell-fish. Its taste for these dainties renders it one of the enemies of the oystermen, the small succulent bivalves being crushed like paper in its powerful jaws. The trail of the drum along oyster-beds is easily followed by the masses of broken shells and the evidences of ruthless destruction, which can only be compared to that produced by the deadly starfish. 
So dreaded are these fishes by oystermen that the owners of beds have adopted many methods to frighten them, one being to anchor highly colored cloths over the beds, which move up and down with the waves; others, according to Ernest Ingersoll, drop pieces of tin on the beds, in the hope that the flashes and gleams of light will drive them off. At such times the drums are often found in vast schools, each fish weighing from forty to sixty pounds, and possessed of an extraordinary appetite for oysters in the shell. Such a devastating horde was caught in a school in Great Egg Harbor nine years ago, in a seine; the fish numbered two hundred and eighteen, and weighed nearly nine thousand pounds. A City Island oysterman reported to Mr. Ernest Ingersoll that drums had mulcted him to the extent of $\$ 10,000$ in a single season. Similar stories come from almost every locality where the fish is found.

The fish spawn in the latter part of March, in April and May, in different parts of Florida, those farther south spawning first. Thus down near Cape Florida the fish spawn in March. Upon the upper Florida and Alabama coast and alongshore, according to Silas Stearns, they spawn in 
April and May, and at Tortugas, as near as could be determined, the spawning season was in March. While an oceanic fish, the drum enters rivers, and I have seen six- or eight-pounders taken with a seine between Jacksonville and Mayport on the St. Johns, and have caught large specimens in the Nassau River near Fernandina, where the water was certainly more than brackish. I have also caught large sea-drums near Old Point Comfort, some localities being famous for them. Perhaps the most remarkable feature of the drum is the habit of "drumming," from which it derives its name. I first heard it when fishing in the Chesapeake, the sound being so loud and resonant as to be distinctly heard several feet away. On my speaking of the incident to the late Professor Baird, he told me that some years previous he had gone out with a fisherman on the New Jersey coast for the purpose of listening to the drums, and that the sounds they produced astonished him. A peculiar feature is that the drumming often sounds differently to different persons. To me it was a muffled boom - boom - boom, with a slight resonance, this from the open water; but later I had a number of large drums under my observation for several weeks in a large tank, and the sounds 


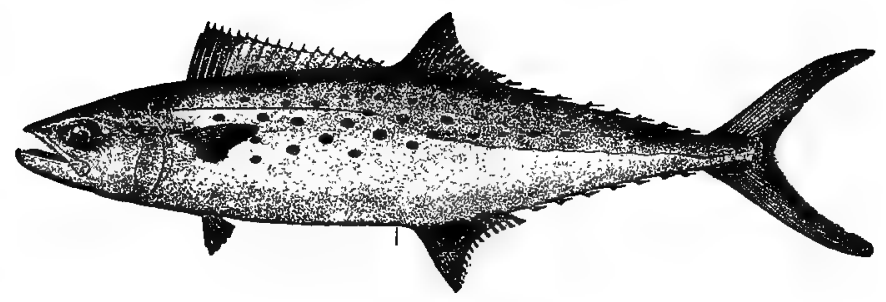

\section{SPANISH MACKEREL}

Scomberomonus maculatus (Mitchill)

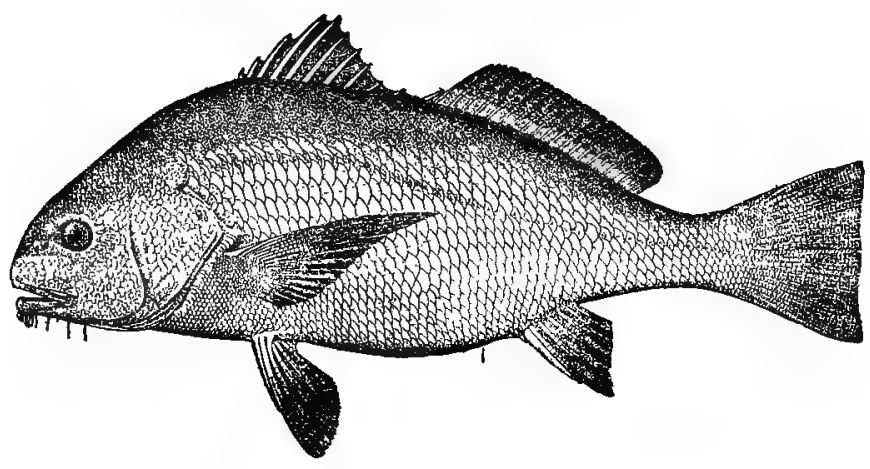

DRUM : GRAY DRUM

Pogonias cromis (Linnzeus) 

were deeper, a roaring boom so penetrating that it could be heard throughout a large room. It happened that I was looking at one of the fishes when the sound was made, and noticed a very slight opening of the mouth and gills, a convulsive movement. The drumming is possibly a sexual call, at least it is heard more in the spring when the fishes are breeding, both sexes uttering it; that produced by the male is the loudest, that of the female is said to be the most musical. The drumming sound is produced by the air-bladder, and whether it can be heard to any great distance beneath the water is a question unsolved. I have been fortunate in hearing the vocal accomplishments of a number of fishes, and several are certainly as interesting as the drum's and one as startling. The common grunt (Hamulon) of the Florida reef would always grunt and groan in a most despairing way when caught. The loudest noise I have heard made by a fish was uttered by a midshipman, a fish nearly a foot long, which I kept in a tank at Santa Catalina Island. This fish would utter a loud resonant croak or bark under water which could be heard with startling distinctness fifty feet away.

Nearly all of the Sciænidæ are sound utterers, 
and that the early Indians were familiar with the notes of the drum is shown by the legend of Pascagoula and its music, it being described as rich, soft strains which rise from the water on still nights, sounding like the notes of an Æolian harp. In the narrative of Bienville, who entered the Mississippi in 1699 , there is an account of the music of Pascagoula. The Italians give the name of covo to one species, which utters a croaking sound. El roncador of Central America has a similar habit, and Sir John Richardson states that upon one occasion he could not sleep on the coast of Carolina owing to the drumming of a certain species. Lieutenant John White of the British navy reported to his government that when anchored at the mouth of the Camboya River, his men were demoralized by strange sounds which came up from the sea, "resembling the bass of an organ mingled with the tones of a bell, the croaking of an enormous frog, and the clanging of an enormous harp." Humboldt also refers to a similar occurrence which is quoted by the same author: "About seven o'clock in the evening the sailors were terrified by an extraordinary noise in the air like the beating of tambourines, followed by sounds which seemed to 


\section{The Drum}

come from the water, and resembled the escape of air from boiling liquid. It ceased at nine o'clock." Not a few black boatmen who fish where the drum is found are terrified by the mysterious sounds.

The large drums are fishes of striking appearance, and while not quick of motion, when they find themselves hooked, they make a remarkable fight and afford good sport. The greatest catches are made with hand-lines; and near Fernandina, in a party of a dozen men fishing, but two had rods, the others being armed with lines which would have held a man-eater shark, and I was told by my sable boatman that even these were sometimes broken by big "sheepshead." But I found that a number fifteen line was large enough for any "sheepshead" up to seventy pounds, and the largest drum known can be taken with a light rod and a number twenty-one cuttyhunk line. So far as tackle is concerned, I should use for these fish the equipment employed for the yellowtail, that is, for large fishes, but the twenty-pound drum can be taken on a much lighter line. Crab and clam bait were used in the Chesapeake, fiddler crabs being a common lure at Fernandina. I used crab, a "fiddler" community affording 
excellent bait for channel-bass or drum. The capture of a drum of seventy pounds' weight will be remembered, if the fish is taken with the rod; and when the angler reaches that part of Florida where the people try to sell him all kinds of articles, from picture frames to impossible flowers, all made of fish-scales, he may accept it as a foregone conclusion that "drum" can be caught in that vicinity, and later on he will witness the extraordinary scene of a longshore Cracker, a Conch, or a " reefer," scaling drum with a hatchet, for the very good reason that the fish does not relinquish its scales with ease. One black oarsman I had, cleaned the large fish by nailing the tail to a scantling and, standing off, scraped off the scales with a sharp hoe.

One of the largest drums it was ever my good luck to catch was far out on the Florida reef and under peculiar conditions, - circumstances which demonstrated the fact that the big drum is possessed of Joblike patience. I was lying prone upon some staging beneath a pier, where I could observe the coming and going of fishes beneath me, unseen, and was intently watching the actions of a number of grunts, which were engaged in a game of some kind, when I saw a large, high- 
built, thick-set, "double-decked," dark grayish fish come slowly out of the gloom of the channel. It swam with great deliberation, and I quickly recognized the high forehead, the big dorsal fin, of the drum, or " big porgy." On it came, until it reached a pile not six feet from me, when it stopped and began, after the fashion of its kind, to dine upon barnacles and teredos incrusting the woodwork, making the rotten and disintegrating wood fly in every direction. As the fish poised and moved around the pile, I noticed something peculiar about it. It had several horizontal stripes which were not fixed, but undulating and wavy, and presently I saw that they were remoras, the peculiar fishes which attach themselves to sharks by the sucking plates upon their heads. There were four of these fishes clinging to the drum, which patiently towed them about wherever it went, bearing them not only without the slightest protest, but with absolute indifference. As the pieces of teredo-infested wood began to permeate the water with a dusky cloud, the remoras disconnected themselves and darted rapidly about, evidently feeding. The fish was one of the largest I had seen, and I determined to attempt its capture. Not fifty feet away, alongshore, were the remains 
of an old wreck, and judging that the fish would visit this, I carefully retreated, and having secured a rod hard by, baited the hook with a third of the crushed tail of a crayfish - the spiny lobster of the reef. This luscious morsel I cast from a high pile of dead coral rock which formed the intervening beach between the pier and the wreck in a highway which I knew the porgy or drum would pass in full view, owing to the remarkable clearness of these tropical waters; nor was I mistaken. The moment my bait sank in about fifteen feet of water it was surrounded by a motley throng of grunts, shad, young gray snappers, porcupine-fishes, angel-fishes, and others, which seized and tossed it about like a ball, creating a commotion that, as I surmised, attracted the attention of the big fish which in a short time appeared, still swimming slowly and with dignity, its jet-black followers trailing against its sides like the barbels or whiskers of a catfish. One broke away and swam ahead, and rushing into the throng, seized the bait. As the ponderous drum approached the lure it stopped, turned slightly upon one side, evidently eying it, while the swarm of small fry melted away as do wolves or coyotes when larger game approaches. The 
bait was evidently satisfactory, as the drum turned until it appeared to stand almost upon its head, then seized it. The remoras, which had been darting about, "got aboard," attaching themselves, and the drum moved on.

At this particular moment I became a factor in the proceedings. I had given the fish three or four feet of slack, and as the line came taut the big fish did not immediately notice it; then it gave a sudden jerk as though of annoyance, making the reel cry out beneath my thumb, and then with a steady bearing off I successfully set the hook into its ample jaws which so easily break large hooks by a mere crushing or grinding process. A streak of gray, with streamers of black, a cloud of sand sent rolling upward into the clear waters, a $z-e-e-e-e-e-e-e !$ long drawn out, and the game was away, a rush so fierce, so determined, that I fully expected to see all the line unreeled; so I descended from the pile of dead coral, my point of vantage, and ran along the beach to a dinghy, hoping to reach it. But the boat was high on the sands and I ran by it, as the fish was now going rapidly down the slope of the channel into deeper water, and headed out the channel. It carried me fifty yards up shore before I stopped 
it with my light rod, and then I had waded out, knee-deep, on to a little shoal which projected into the channel, from which vantage-ground, the home of the mullet, I played my fish and was played. I would gain ten or twenty feet, then lose it, then by turning the fish inshore and wading rapidly, I would regain the lost line. And so, giving and taking, the contest went on, every now and then the fish making a desperate rush; and the closer in I reeled it the more savage became its plays. It had one singular movement which appeared to be a rapid dive in a half-circle, bearing away on the line with all its power, then evidently turning suddenly, which gave a slack line for a second as it ran toward me, which was perhaps a trick to gain line. But I foiled it by more than ordinary good luck, all the time being carried slowly up the channel, but now moving gradually in so that $I$ at last reeled the fish up the steep channel slope on to the shoal and had it in three feet of water, where it circled me several times as I slowly and carefully backed inshore.

By this time one of the boatmen had appeared and now waded out; and, as well wearied with my bare-headed fight under a terrific sun, I brought the fish in, he grained it - a savage and barbar- 
ous method of gaffing, but possibly excusable under the circumstances - and dragged it out upon the sands, remoras and all, the four attendants refusing to leave until they were forced off. This fish weighed, if my memory serves me rightly, about seventy pounds, and was the largest "big porgy" ever seen at Garden Key, at least by the fishermen I knew. I gave it to the man I often fished with. He was not a Tamisio, and I fancied he looked at me reproachfully the next day when I asked him how it tasted. His reply was that it might have been "fine fishin', but it was mighty tough eatin'." So my biggest drum undoubtedly went to feed the sharks, which were the principal scavengers along the key of the Gulf.

Small drums, or "porgies," from eight to twelve pounds were highly valued and caught in the same localities as sheepshead, though in deeper water, one of the best places being on the edge of a deep channel opposite Sand Key, where "Long John " could soon fill the well of the "Bull Pup," as he called his old sloop, which went to the bottom one day in a hurricane. The fishes were probably revenged by using her as a retreat until the teredos reduced her to dust. 


\section{CHAPTER XXI}

\section{THE SHEEPSHEAD}

"I shall stay him no longer than to wish, ... that if he be an bonest angler, the east wind may never blow when he goes a-fishing." - IzAaK WALTON.

THE ancients long ago discovered the value of the sheepshead or its representatives, and the Chrysophrys of the Greeks, and Aurata of the Latins, was the gilthead of the English, according to Sir John Richardson. Sergius Orata, a famous Roman well liver, considered the gilthead the finest of all fishes, and it is said that his surname was derived from this fish. $\mathrm{He}$ introduced them into ponds, and cultivated oysters and other shell-fish that the giltheads might have the most delicate food. According to Pliny, he suggested and designed the oyster nurseries at Baiæ upon which were fed the sheepshead which were sold to the Roman epicures. Few fishes to-day excel the sheepshead when properly served, and as a game fish it ranks high when taken with a light rod and the lightest line. 
I have fished for sheepshead alongshore from Long Island to the Chesapeake, off the Georgia coast at Marion Island, and far out on the Florida reef, and have always found it a gamy fish.

It belongs to the family Sparida, to the subgenus Archosargus, and is known to science as Archosargus probatocephalus (Walbaum). Its head is large and high, the body deep, with a long dorsal fin; the tail forked but not deeply, a powerful organ. The mouth is large and provided with a curious array of teeth, those in front being conical or incisorial, for tearing or biting. Back of these are others, in two or three rows, which are crushers or grinders. These are suggestive of the habits of the sheepshead, which is equipped by nature to live upon shells and crustaceans, and wherever found it feeds upon young oysters, barnacles, cockles, and crabs of various kinds. With the front teeth it wrenches shells from rocks or piers, passes them to the grinders, where they are crushed as though passing through a rock breaker. In color the sheepshead is gray, with six or seven vertical stripes which make it very conspicuous. It is a slow-swimming fish, frequenting rocky shores in shallow water, piers, and old wrecks, the latter 
particularly being favorite resorts; and whenever a wreck can be located on the Atlantic coast, good sheepshead fishing will be found. There are several such ocean rookeries between Newport and Delaware Bay which have become famous. I have had excellent fishing near Old Point Comfort, where I have taken sheepshead from the wharf, and at Beaufort. The fish has never been seen north of Cape Cod, and some localities which knew it well several years ago, know it no more. I was informed by an old fisherman at Fisher's Island that when he was a boy sheepshead were plentiful, but faithful fishing there failed to obtain a rise; though not many miles away, on the south shore of Long Island, the sheepshead was the common fish. I once accompanied a party up the beach, near Cape May, who waded out into the breakers, which were not very high, and made long casts out over the supposed location of an old wreck, some exciting sport being the result. The fishes were large and extremely gamy, making an exhilarating fight, rendered the more exciting by the capsizing of an old angler by a sea as he was about to land his fish.

The oyster-beds of the Chesapeake are favorite localities for sheepshead, and I have taken the 
fish from the north beach at Old Point Comfort, where they were evidently feeding upon the crabs which fairly covered the bottom at times. The bait used was a single soft-shelled crab - a killing lure. There are numerous fishing-grounds about New York bay well known to boatmen at Staten Island, Fort Hamilton, on the New Jersey shore, Jamaica Bay, Fire Island, South Bay, and various other localities. All these places have their habitués; some fish with hand-lines, some with rods, who have the shallow mussel beds and other "spots" located off which they anchor, casting on to the bank with good, bad, or indifferent results depending upon tide and weather. The "beds" can be often recognized by the quantities of broken mussel shells. On the outer Florida reef the feeding-ground of the porgies, as they were called, could be determined by a dark spot on the otherwise clear sand of a shallow lagoon, surrounded by the broken shells of bivalves. The Hon. William Elliott, in his delightful "Carolina Sports on Land and Water," describes the sport in Port Royal Sound, where large enclosures were built out into the water to encourage the growth of shell-fish - the food of the sheepshead. Stands were also erected for the angler, who was a man 
after the heart of the salmon fishermen, the rod used being "twenty feet" long, probably a single bamboo pole.

Such an angler created a sensation in Southern California waters several years ago by advocating long rods. It so happened that I accompanied him one day and observed its working. He had a long bamboo pole, the longest and stoutest I remember having seen, and the method was to place the butt of the rod in the leather cap on the seat, and when a strike came merely hold on. I saw this long-rod philosopher play a thirty-pound yellowtail, while I was convinced that he was fast asleep; the fish seized the bait and plunged down, hooking itself, taking the tip several feet under water; but the tremendous strain was too much for even this gamy creature, and the rod gradually raised it, when the fish made another rush, and again the back spring lifted it. And so the fight went on until the angler awoke and reeled in the exhausted fish. Long rods are to be commended, but the rod which does all the fishing is an embarras de richesse.

Mr. Elliott baited one hook with a raw oyster, its attributes being an appeal to the fish's sense 
of smell, - in a word, to attract it; while on the second hook was a boiled oyster, strong and tenacious, which served as the killing lure. The fish is supposed to migrate, that is, it disappears from the eyes of fishermen in its northern haunts in winter, either moving south, out into deeper water, or lying dormant. At Old Point Comfort, Virginia, the sheepshead appeared in April, sometimes in March, disappearing in October. On the Florida reef, at Garden Key, it could be caught the year round, but was much more frequent in summer. Georgia is apparently the limit of the supposed migration; from here south it was found the year round, the fishing being merely affected by the question of bait. The sheepshead is common all along the coast of Florida in winter, the numbers increasing the farther south one goes. The Indian River region down to Biscayne Bay is a favorite locality for it. Mr. Stearns states that on the mainland Gulf coast the fish is found during the entire year, especially at St. Marks River, Cedar Keys, Homosassa River, and to the south. On the other hand, in the northern Gulf localities, as Appalachicola, St. Andrews, Mobile, and Pensacola, it is migratory, appearing in large numbers 
only in October and November. The fish spawns in April and May in these localities. On the outer keys spawning fish were found in the shallow lagoon east of Long Key in the latter part of February and the first weeks in March, and shortly after the young fish were seen, while several weeks later a seine hauled about the old mangrove roots would contain great quantities of young, easily recognized by the black stripes or bands.

The average fish I caught on the reef weighed from seven to twelve and eighteen pounds, while individuals weighing twenty pounds were frequently taken. Among New York fishermen stories of extraordinarily large sheepshead are often reported, but individuals weighing fifteen pounds are considered large catches. It is marvellous how a fish will shrink and shrivel when subjected to the deadly scales that have not been encouraged to make the most of things. I once saw a sheepshead which had been caught over an old wreck, near Asbury Park, which was hailed as the record; but it appeared later that the fish was "in ballast," having been made a repository for all the lead sinkers of the party.

The sheepshead is trapped and seined, taken with 
hand-lines, and looked upon as a mere commercial commodity alongshore; but it is a game fish in all the term implies when caught with a rod. In the question of tackle there is the greatest difference in taste, and most of the sheepshead are hauled in with heavy lines, the latter being anchored to the ground with a heavy sinker. Other fishermen use tarpon rods, or rods which sell as bait rods, made for use on the fishing steamers which run out of New York to the banks. They are stiff and heavy, to permit the hauling of a dead weight from a considerable depth. My own experience with the sheepshead has been with a light rod not less than eight and a half feet long and a cuttyhunk line as delicate as one's conscience will permit. I took my largest sheepshead on a number nine cuttyhunk line; and as the average fish weighs but six or eight pounds, a very light line can be employed. A sinker is necessary at times. I have fished at the mouth of the St. Johns, where my heavy sinker seemed to be always on the surface; but there is a lull in the current between tides which is a good time to begin to fish. Again, the bait can be cast up the current and allowed to drift down. There is more true 
satisfaction in taking a fifteen-pound fish with a single gut snood and a small hook than with a wire leader designed for sharks, or for large and powerful fishes which play so long that their fine teeth are very likely to saw and sever the more delicate equipment. An interesting fish sometimes found with the sheepshead is the triple-tail, Lobotes surinamensis. It is a large and powerful fish, reaching a weight of forty or fifty pounds. It has a remarkably wide geographical range, from China to America, and at many intermediate localities. I took a specimen at the "Rip-raps," Old Point Comfort, which weighed about twenty-five pounds, the fish making a very gamy fight, and later I saw specimens which had been taken on the St. Johns. In color it is silvery gray, very attractive when taken, and resembling the common "blue perch" of Santa Catalina waters. It is high, short, and "thick-set," the dorsal and anal fins extending so far backward as to give it the appearance of having three tails, hence the common name. It is taken all alongshore, from New York to Florida, but in such limited numbers that it has never been a factor in the catch of the anglers of any locality. 


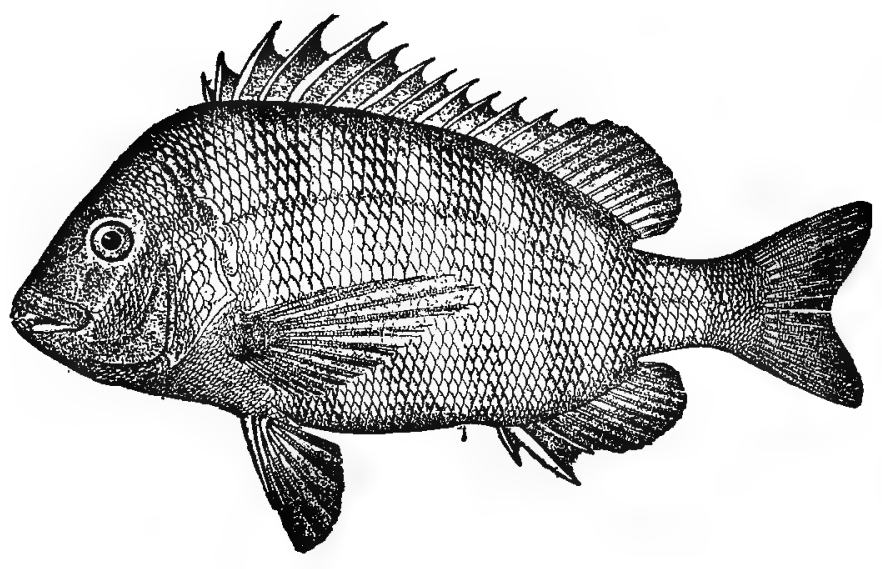

SHEEPSHEAD

Archosargus probatocephalus (Walbaum)

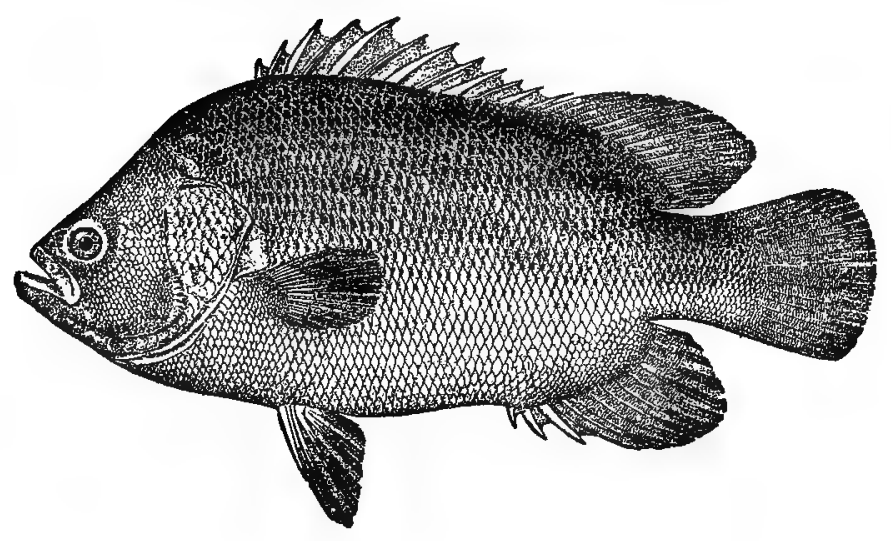

TRIPLE-TAIL; FLASHER

Lobotes surinamensis (Bloch) 



\section{CHAPTER XXII}

\section{THE PARROT-FISHES}

"And there crystal pools, peopled with fish,

Argent and gold; and some of Tyrian skin,

Some crimson-barred. And ever at a wish

They rose obsequious, till the wave grew thin

As glass upon their backs, and then dived in,

Quenching their ardent scales in watery gloom,

Whilst others with fresh hues rowed forth to win

My changeable regard."

- Thomas Hood.

IT is said that the gods held the scarus as first among fishes, and Pliny tells us that during the time of Emperor Claudius an epicure and angler of great wealth, one Optatus Elipertius, collected a large number of the most beautiful of these fishes and liberated them in the Italian sea for the benefit of posterity. The waters of the outer reef, and of our new colony Porto Rico, abound in these birds of the sea, which, in their fanciful coloring, brilliant, indeed dazzling, tints, are among the most conspicuous of the dwellers in these tropic seas. In my early days on the reef 
I at times fished from a small craft known by the euphonious title of the "Bull Pup," under the command of a genial character of the reef, "Long John." I frequently hooked a fish on the edge of the coral in fairly deep water, which bit the hook in two as cleverly as I could have cut it with a file, though it was only when I fished with the small I/o hook described in angel-fishing. I believed the unknown to be a small shark, but my Conch boatman, Long John, said it was a loro verde, a fish which had a beak like that of a parrot, - was, in fact, a parrot-fish. Acting on his suggestion, I changed the hook, putting on what he termed a "grunt hook," which had a leader, or snell, of silver guitar string. This hook was what is known to dealers as a number five, spring steel blackfish hook, and while small, was stout and inflexible, almost impossible to break. With this and a very light line and pliable rod I continued fishing, landing first, as though to show what bizarre game there was over this remarkable coral wall, a porcupine fish, which when brought to the surface expanded to a perfect ball covered with spines, and when cut loose sailed away on the sea like a balloon.

I next hooked a fish which made so gallant a 
rush that the reel sang again, and Long John, unused to rods, stared in amazement at the bamboo, and expressed the opinion that it was "dun fer." I can recall no North Atlantic fish, except a large bluefish, with which to compare this gamy creature. It made a clean dash of at least one hundred feet down into deep water, evidently following the sloping bottom, then circled around, coming back when checked, stopping and evidently shaking its head, imparting to the rod a most erratic series of motions which seriously threatened its future usefulness. At times the rod was more than outclassed by this fish, and I considered it good fortune more than anything else that I succeeded in holding it at all. Now it was away, deep in the blue channel, then came rushing in, plunging down the coral wall by the side of which we were fishing. A gamier, more keenly active fish I never had played. For sustained and powerful resistance, it was a royal fish, and when finally it was brought to the surface after a hard contest, I saw that I had been playing a despised and, so far as anglers are concerned, utterly neglected parrot-fish. I was amazed. I was familiar with the young, and of all fishes it is to the eye the slowest, the most 
easy-going, playing about the coral heads, lying in gorgonian snug corners, a gorgeous poseur, a scaled coxcomb of the fishes' rialto, perhaps the last individual of this gorgeous throng that would be selected as a hard fighter, a breaker of hooks.

The names given fishes are sometimes without rhyme or reason; but no better appellative could be chosen than the sea-parrot for this doughty creature which lay upon the surface, rolling its oddly colored blue and yellow eyes, flapping its broad pectoral fins, and occasionally lifting its big tail to scatter water over the boat, as though to emphasize the fact that while in the toils it hurled defiance at us. In color and general appearance it suggested some of the gaudy macaws, especially in color, as encased in an armor of huge scales it was painted a vivid turquoise blue from head to tail, and possessed a remarkable set of beaks, solid nippers, and biters also colored. Other fishes have more tints, are more beautiful; yet I recall none which made a more striking impression upon my mind than this seaparrot, which eyed me so intently, I fancied, wondering whether I was the kind of an angler who had a high appreciation of a good fighter and would release it, or whether I was merely 
a plain pot-hunter fisherman, who would murder it in cold blood, and stow it away in a bag to gloat over its size and weight with other barbarians ashore.

My catch was estimated at three and a half feet in length as it lay on the surface, for I would not allow Long John to take it in, much to his amazement; and that it would have tipped the scales at nearly thirty pounds, I am confident, having weighed several individuals taken in a trap or net for scientific purposes, which tipped the scales at twenty and twenty-five pounds. As it lay on the water it was a beautiful object, seemingly painted with the same brush used in decorating the marvellous turquoise channels of the reef; body, fins, tail, even the iris, was the same rich and radiant hue, giving remarkable expression to its eye. At the base of the fins the blue was deeper, more intense, bordering on purple; the belly was greenish blue; while upon its "cheeks," below the eye, this macaroni of the "gulfs enchanted" had touches of rouge, - at least a decided pink flush was seen that heightened its gorgeous costuming. The lower jaw was touched with yellow, the pupil of the eye had a narrow yellow band inside the deep blue iris; give to the 
fish a long, high dorsal, a ramlike "snout" extending beyond the mouth, and a faint idea of this fish may be had by the reader who has not seen it. My boatman announced it as "pizen," and proposed to kill it on general principles; but so rare a foeman, so gallant a contestant, never died by my hand unless it was strongly in demand, and to Long John's wonderment I cut it loose. In the years I spent on the reef I do not think my catches of large parrot-fishes would number over ten or twelve, and this was the largest, though I saw a crudely mounted specimen in a shop in Key West which must have weighed over forty pounds; but such fish are the exception, a twenty-five-pound fish being moderately rare, the average fish seen around the coral heads near in ranging from five to eight pounds. I unhesitatingly give the loro a place among the hard-fighting game fishes of our tropical and semi-tropical waters when taken with proper tackle.

This fish, known as the blue parrot-fish, loro, and many local names, is the blue scarus (Scarus coeruleus) of science. It has a wide geographical range from the coast of South America to Maryland. On the reef the fishermen and boatmen 
with whom I came in contact all believed it poisonous, and invariably killed and threw it away. It affected water of medium depth, but came in upon the lagoons at night to feed. At Porto Rico, according to Evermann, it is a more or less important food fish, the people not having the foolish superstition of many of the Conchs. Dr. Jordan states that "In Hawaii the parrotfishes, being eaten raw, are very highly esteemed and even once held as tabu, to be touched only by royalty." As near as I could determine, the men whom I knew, believed the fish to be poisonous because it was "green," when in point of fact it was blue, though another large green parrotfish and several small ones found here fell under the ban. Long John explained to me that on the Cuban coast there were "submarine ledges of copper," which certain fishes, like parrot-fishes, ate and so became poisoned. No argument could convince the men that they were mistaken, even though I ate the parrot-fish and others, and still lived to tell the story. Long John met this self-sacrificing experiment with the remark that "Some folks was pizen proof."

With the blue parrot-fish at Long Key another form, Pseudoscarus guacamaia, equally as large 
was occasionally caught in the manner described with a very small but stout hook on the face or at the base of a perpendicular coral cliff. The channels here were very deep and precipitous, and were often lined with branch coral which formed an almost perpendicular wall, a perfect cheveaux de frise, the interstices of which formed favorite lurking-places for the parrot-fishes of large size. This fish, though rarely caught with a line, was, when three feet in length and ranging from eighteen to twenty pounds in weight, a powerful, active fish. Large individuals were frequently taken at night on the edge of the lagoon, showing that, like many others, it came into the shallows to feed. It was held in no esteem by the fishermen, being considered poisonous; its only economic value lay in the "bills," which were a vivid blue when fresh, green later, and which were sold to visitors as curiosities. The remarkable feature about these fishes are the singular "bills" or teeth, which in the different species coalesce, more or less, forming a sharp, solid ridge instead of several teeth. This biting armament partakes of the color of the fish. In the large parrot-fish described they were pinkish and white; in another genus, green. The 
fishermen believed that this armament enabled the parrot-fishes to bite off the tips of branch coral, which constituted their principal food. When I expressed a doubt of this, Long John took me to a "grove" of branch coral and showed me the tips of countless branches where the polyps had been destroyed by the parrotfishes; but I found that the real "coral eater" was a huge marine worm, which literally drew itself over the tips of branch coral as one would pull the finger of a glove, swallowing it to a distance of four or more inches, thus securing the polyps. That the parrot-fish could bite off a coral branch there is little doubt, or that it does at times I would not venture to deny; but its principal food consists of crustaceans, seaweed, echini, and the ordinary game of the tropical shallows, - this from an examination of its internal economy.

But a few ardent anglers will have the temerity to spend a summer on the outer reef where my old boatmen, Long John, Bob Rand, Chief, and Busby, lie buried by the great current which sweeps silently on through these isles of eternal summer. 


\section{CHAPTER XXIII}

\section{THE DOLPHIN}

"A shoal of dolphins, tumbling in wild glee, Glowed with such orient tints, they might have been The rainbow's offspring, where it met the ocean."

- MONTGOMERY.

FEW anglers have taken this beautiful creature, whose home is upon the high seas, and whose presence often gladdens the heart of the mariner in the idle forties; hence few know the amount of power, force, exhilaration, and game qualities possessed by this gorgeous acrobat, this harlequin of the sea. It happened some years ago that I was caught at sea in a remarkable calm, which continued for nearly a week, during which period the ship drifted many miles, but sailed not one. We were in the Gulf Stream, so went on at a mysterious pace, yet without sails, to the measure of the eternal tapping and rippling music of countless reefing points and the nerve-rasping creaking of booms whose jaws, drying under the 


\section{The Dolpbin}

pitiless heat, seemed to scream in very agony at every lunge of the ship. All the expedients known to mariners were brought into play. The foremast was hammered by all hands. The captain of the galley, a jolly shipmate under some circumstances, whistled for the wind with a rare faith, while the good skipper swore and believed himself bewitched as the days sped by.

Such monotony became intolerable, and I began to occupy myself by rowing about in a boat, always keeping near the ship in case the welcome wind should come. We were on the outskirts of the famous Sargasso Sea. Great patches of sargassum, the gulfweed, covered the water everywhere, each islet forming, at least to me, a fascinating world in itself. They were floating islands with marvellous populations, - crabs, shells, shell-less "shells," and fishes, - all colored the exact tint of their surroundings, a rich green. Here was the strange antennarius, or walking fish, with its nest, a bunch of weed held together by a glutinous secretion and covered with myriads of eggs the size of a pin's head. So marvellous was this fish in its mimicry that I could hardly distinguish it from the weed when lying on it, even with my face but two feet distant. 
On these trips I took a rod, hoping to catch a bonito, and so it came about that one day, I think the fourth of our imprisonment, when every one was desperate, that I ran foul of the misnamed dolphins. I was sculling along to enter a little bay in the gulfweed, when I saw a number of large fishes come coursing along, charging the weed evidently in search of small fry. Quickly taking the rod, which was baited with a small flying-fish that had flown aboard ship in the night, I cast fairly among them, and I have reason to believe that every dolphin in the pack - and I say pack advisedly - dashed for it. One fortunate fish took it on the run and never stopped until two hundred feet of my line was unreeled, to such music as I had never heard before. The following day, when I took the reel apart to see what had happened, I found the interior flaked and covered with brass filings, which told the story of that rush. The fish was followed by the entire school, and when I finally checked it, they noted every move until I had the gamy creature in the toils. Such rushes in and out, such doubling, such sudden stops, were never seen. Suddenly with a wild rush the fish would encircle the boat, then dash into a mass of weed, 


\section{The Dolpbin}

and for fifteen minutes I did not gain thirty feet on this glorious fish, and I never would have caught it on my light tackle had not hard luck, the very hardest, fallen to the lot of this beautiful "offspring of the rainbow." I fought it, played it, turned it, but seemed incapable with my rod and line to bring it in; and finally, in one of its rushes in a circle, it dashed into a particularly dense mass of gulfweed, and with the line so completely involved itself that I took it with ease - the most bare-faced act of piracy ever perpetrated in this latitude, I dare say.

When I approached, stopping now and then to reel in the slack, the dolphin was lying flat upon its side almost entirely out of water, its efforts and struggles forcing it further out on the thick mat of weed. How shall I describe its wonders, its flashes of color, gorgeous changes from tint to shade, its dazzling effulgence? I have never seen anything to compare with it in suddenness of unexpected beauties, unless I except a large squid which I once kept in confinement alive for an hour, over whose surface color changes in all the tints of red passed with such rapidity that it could only be compared to heat lightning, which I have observed in the tropics 
when there was absolutely no cessation, but a never ceasing pulsating glare. I could think of but one comparison, - the interior of a large and brilliant haliotis shell with its marvellous shades of blue, yellow, red, pink, violet, black, and white pearl. This might convey in some degree the beauties of the dolphin as it changes color in the bright sunlight. The fish was nearly four feet in length, and I should judge weighed in the neighborhood of sixty pounds. Its head was large, mouth big, eyes radiant, and down the back to the sharp-pointed tail a long, purple dorsal fin splashed with other tints, itself a coat of many colors.

In general appearance the dolphin is one of the most attractive of all fishes. The prevailing tint is greenish olive, brownish olive above; the belly white with a golden sheen; but the most marked ornamentation is a series of vivid splashes of labradorite blue along the upper portion. Add to this, blue-splashed fins and a yellow tail, and some idea of this radiant creature may be imagined - a fish which, if available to anglers near shore, would take its place among the great game fishes of the world.

A few days later the "dead calm" gave way before the trade: a sleeper awakened, and the 


\section{The Dolpbin}

ship made her course again under the stiff breeze, with cordage whistling - the music of Arion in the Ægean Sea. The dolphins came in schools and raced along under the cutwater, darting by it, performing mighty feats of valor. It was an easy matter to observe and catch them, and swinging from an improvised seat on the dolphin striker the men supplied the galley with these splendid fishes.

Few fishes are better known than the dolphin, yet as rarely seen at close quarters, though I have often taken them from the bows of ships at sea, and the sport is a common one among sailors. The real dolphin is a well-known figure in mythology. It was Arion who, captured at sea by pirates, when sentenced to death, asked permission to play upon his harp. The notes drifted away over the sea so sweetly that they attracted a school of dolphins, and when Arion was tossed over he fell upon the back of one and was carried to the shore; hence we see in the heavens Arion's harp and the dolphin forming the well-known constellation of that name.

The dolphins (Coryphanida) are pelagic fishes living on the high seas and offshore on the American coast from Virginia to the Rio Grande, often 
venturing beyond these lines, but rarely if ever seen inshore. There is a single genus and but two species, the one described, $C$. hippurus, a large, powerful fish, attaining the length of six feet, and $C$.equisetis, from two to three feet. The name dolphin is an unfortunate misnomer; the fish might better be called harlequin, as the name dolphin is applied to the mammalian dolphins - small, whalelike animals, equally common and referred to in mythology. Doubtless few anglers have seen the real dolphin (Delphinus) landed. I once saw a bottle-nose dolphin, weighing about fifty pounds, which was taken with hook and line and sardine bait at Santa Catalina. The angler supposed he had a seal, and landed the animal only after a hard and consistent struggle; and knowing all the details of the capture, I am enabled to place this interesting creature on record as a very gamy catch.

While the fish dolphin is a gorgeous creature, it has been my good fortune to see at the California islands another fish, a cousin germane, whose glories cannot be adequately described. This is the butterfly-fish, the opah, Lampris luna, known as cravo, poisson luna, soho, and other names in all parts of the world. It attains a 
weight of nearly five hundred pounds, is an active, hard-fighting fish extremely difficult to catch, and may be considered the rarest of what might be termed the pelagic game fishes of the United States, which, though rarely seen near the mainland shores, are found about the adjacent islands of the Pacific from the Coronados to the Farallones, and on the high seas in general. Large individuals have been seen at Monterey on the California coast. I remember well when a fisherman at Avalon came to tell me of the splendid fish he had taken, and the beautiful object which met my eyes on going to the beach where the opha, a small individual weighing perhaps fifty pounds, was hung. Its normal or ground tint appeared to be dull silver, but over this was drawn a seeming fabric of rose-lilac hue, while dotted over the surface were round, pronounced, vivid silvery spots, giving the fish a most artificial appearance. The fins were vermilion; the eyes very large, larger than in any other fish I recall, and a deep blue, completing a make-up which was at once striking and beautiful. The flesh was a deep red, and recalled salmon in its flavor. If this shy fish of many glories was available, it would afford excellent sport to the lover of big game at sea. 


\section{CHAPTER XXIV}

THE MARIPOSAS

"There we sit

For a bit

Till we fish entangle."

- Walton. Piscator's Song.

Among the fishes of semi-tropical America there are many which are passed by with indifference by anglers for the very good reason that their limited time is wholly occupied with tarpon and the larger game. To know them all and know them well, it is necessary to spend the hot months of summer in the haunts where they are at their best. It was my fortune for several years to have the midsummer fishing on the extreme outer Florida reef - the land of the "tin cow" and the roaring nineties, where the heat at times was intolerable, and only cheerfully faced by youth or the most ardent lover of sport. I see the long stretch of water, the green-capped keys lying on its surface like gems, the clumps of graceful cocoa palms, through which the wind 
sighs and makes rippling music; the groups of mangroves growing in the water, the long submerged reef, the old wreck, the clouds of snowy terns. I recall the submarine garden, the coral groves cut by strange channels of turquoise-blue, the colossal heads of coral eaten out into curious, vaselike shapes, the masses of plumelike gorgonias floating, waving eternally in the restless current, the paradise of the southern seas.

In these gardens were some of the most beautiful of all fishes, known as mariposas and angelfishes, the various species being garbed in colors so brilliant and startling that one could almost believe that nature was masquerading. In the wealth of other game they are rarely noticed and rarely caught, so small are their mouths. Especially rigged tackle is necessary, at least the angler fishing for the gray snapper, yellowtail, or jack would never take a mariposa unless by accident; but once caught, they would always be included among the delight givers of the reef.

Anchoring just outside the fringing reef on which the sea was beating, over one of the beautiful coral plantations, with a water-glass myriads of these gorgeous fishes could be seen in water fifteen or twenty feet deep, some attaining a 
weight of twenty-five pounds, though represented about the wharves by very much smaller individuals. My first introduction to them was more by accident than anything else. I was fishing for yellowtails (Fig. 9), the gamy gold-tinted fish so common on the reef, when a huge barracuda came drifting in from the outer Gulf Stream, and hovered about, looking us over with its black staring eyes, which gave a suggestion of how the plesiosaurus might have looked. I had no bait, so dropped a "fly" hook over, hoping to catch a small grunt or yellowtail which could be used as a lure for the barracuda. Instead, I hooked a spadefish of three or four pounds, which gave me so spirited a contest that I determined to fish for them with intent to kill. An eight-foot bamboo rod was at hand and a delicate line comparing to a number twelve cuttyhunk; to this was added a gutsnelled hook equivalent to a number eleven steel sproat hook, a very small affair for so powerful a fish, but necessary on account of the small mouth of this game; briefly, the hook should be very small but stout. This I baited with the red meat of the crayfish, or spiny lobster, and cast a few feet out. Some manipulation was necessary to keep it from the smaller fry, but after a number 
of small catches I hooked a fish which soon demonstrated that it was essentially game. I had no thumb brake, and the fish took my line at marvellous speed, resisting all attempts to capture it, and putting the delicate tackle to the test more than once, coming in only after a well-sustained protest. The captive must have weighed between eighteen and twenty pounds; and on other occasions I took larger specimens of this interesting and conspicuously beautiful fish, shaped very much like the typical angel-fishes, with a high, elevated body much compressed, the upper or dorsal and anal fins extending back in graceful points suggesting plumes, giving the fish the appearance of having three tails. My boatman, Long John, called it a porgee, the third fish to which the name was applied on this portion of the reef.

The fish, which is Chatodipterus faber of science, has a wide geographical range. I have caught small individuals in the Gulf of Mexico, at Aransas Pass, Texas, at the Tortugas, Old Point Comfort, Virginia, and have seen it taken from a pound net in New York harbor near Coney Island. Dr. Jordan describes it from San Diego, California. The young are easily recognized by the six 
or seven pronounced stripes, one of which passes directly through the eye. In Florida I found this fish everywhere about the large coral heads, always in company with angel-fishes and yellowtails, adding to the manifold attractions of these submarine gardens. The most constant companion of this gamy creature was the black angelfish, which so far as shape is concerned closely resembles it. Very large individuals attain a weight of ten pounds or more, averaging much smaller about the wharves and docks; yet few fishes of their size present so brave a front and make so desperate and sustained a fight against capture. The struggles of a trout of the same weight or even a black-bass fade into insignificance when compared to this broad gray or black fish of extraordinary countenance and vivid white lips. The angel-fishes proper belong to the family Chætodontidæ, which includes nine or ten genera or about two hundred species, mainly found in tropical seas the world over, in some localities being known as coral-fishes, and everywhere among the most gorgeous and beautiful of the denizens of the ocean, their vivid coloring rendered more striking by the contrast of the sombre olive-hued coral. Flashing like gems in 
all the colors of the rainbow, this group is well named the mariposas, or butterfly-fishes.

The black angel-fish, Pomacanthus arcuatus (Fig. 9), might better be termed the gray angel-fish, as in thousands observed on the reef I never saw a black individual or one that approached black; hence the black angel-fish is black in the sense that the white elephant of Siam is white. Its color is a peculiar beautiful gray, some of the scales being very dark with white borders. The broad tail has a white border; the mouth is pure white. All these fishes, due to the lofty or elevated "forehead," the projecting mouth, and their faculty of moving the eyes more than many other fishes, have more of a "face" in the human sense than almost any other group of fishes; and to watch them in the home of their choice is an interesting, indeed, fascinating, occupation. In movement they are exceedingly dignified, spending much time posing among the branches of coral, and assuming many mannerisms which attract one's attention. I hooked them readily with the tackle described, and was always repaid. The first rush away of the fish is so violent that the novice almost invariably loses the delicate line and hook; and so impetuous is the dash, so 
determined the resistance, that one is easily overmatched.

In watching the fish I found that it made its sturdy resistance by keeping its broad side to me, fighting inch by inch; and when wearied it would bound upward and wear away round on the other tack, presenting its opposite front, all the time making a struggle that could but arouse the admiration of the angler. These experiences were, of course, with light rod and delicate tackle. With a twenty-five-ounce rod six and a half feet long, and a large line, the angel-fishes would drop back into the ranks of "bait stealers" and not be considered worth catching, nor indeed would a trout under the same circumstances. I have seen the black angel-fish taken in Virginia, though rarely, its home being in tropical seas, and on the Florida reef and the West Indies in general. There it is one of the commonest of fishes, and by no means a poor table fish, though there is a strong prejudice against it in some localities, many believing it to be poisonous.

Not so common, but a gamy catch, is the yellow angel-fish, Holacanthus ciliaris, with brilliant yellow margins to its scales, its body not so elevated as in the black angel, the tip of what 
might be called the dorsal and anal "plumes" extending beyond the tail with graceful sweep, making the fish a charming object in the gardens of the sea. It attains the length of two feet and is often seen, its curious face peeping from some crevice in the coral, from which it can be lured with crayfish bait. The young of nearly all these angel-fishes differ so in appearance from the adults that they would hardly be suspected as relatives, and often are far more beautiful. In the Southern California waters is found a form known as the golden angel-fish. The adult is a rich golden yellow with no break; but the young, which I have kept alive of all ages, present a singular contrast to them and are thought by the fishermen to be an entirely different fish, and are called "electric" fishes from the fact that the blue tints which mark them are so vivid that they appear to flash with an iridescence, or like an electric spark. The very young are blue over the entire surface, but as they grow this brilliant and beautiful color seems to give way and they become spotted, then striped, then faintly tipped with blue, finally losing it entirely to become golden angel-fishes in all the term implies. 
An interesting feature of the latter fish is its tameness. Through a water-glass I have watched a diver in armor at the bay of Avalon. who sat upon the bottom and crushed some black echini, whereupon numbers of these fishes swarmed about him, eating from his hand with great complacency. At my request he took down a wire box and placing some bait in it, caught several of the little creatures. On the Florida reef a brilliant assemblage could be collected by tossing over some crayfish at which the radiant creatures would rush, and amid them there generally would be the singular surgeon fish which carries its lance in the side of the tail (Fig. 9), which is freely used to enable it to hold its own in the struggle for existence. To land the game is not everything in fishing, or the chief end of the angler; indeed, these diversions, the study and observation of the habits of fishes, the unexpected glimpses of their home life, the view of their beauties and charm of coloring, are a part of the day's fishing, which are perhaps more compensating than to make a goodly bag. This is especially true on our southern borders, where vast reefs stretch away, embracing coral lagoons and shallows. 


\section{CHAPTER XXV}

\section{THE HALIBUT}

"Flat fish, with eyes distorted, square, ovoid, rhomboid, long, Some cased in mail, some slippery-backed, the feeble and the strong;

Sedaned on poles, or dragged on hooks, or poured from tubs like water,

Gasp side by side, together piled, in one promiscuous slaughter." - BADHAM.

That the halibut might be a game fish under certain conditions dawned upon me some years ago when hunting for the tuna off the Maine and New Hampshire coasts. My companion, a local fisherman of repute, had anchored the dory about six miles offshore, and standing upright, with a line to port and starboard, was "codding" after the approved method. Every few moments he would drop one line and haul vigorously on the other, and in due course of time "boat" a fine fish, during which operation I took the first line and so experienced some of the melancholy joys of the deep-water hand-liner. It was while 
relieving my companion in this way that I hooked something which bade fair to lift me out of the dory, then when I renewed my hold, the unknown jerked my arms into the water, whirling the dory about in the most spirited manner, so convincing me that I had hooked a ground shark that I was inclined to pass the line to the professional. But suddenly the fish began to rise and came to the surface nearly one hundred and fifty feet away, tossing the water into foam, following it by a dash around the boat that would have made the reputation of many a game fish.

"A halibut, I'll swan!" exclaimed my companion, "and a sockdolliger."

Now every real angler knows what a "sockdolliger" is, and it is hardly necessary to refer to it; but for the benefit of the layman, the unfortunate who has never fished, I may say that the term applies to those remarkable fishes of gigantic, even heroic size which constitute the main subject of conversation among anglers in the out season. It is the fish that always escapes, the record-breaker; every angler has hooked it a score of times, but has never landed it, and if the truth were told, never expects to.

It will be seen that I was in a most fortunate 


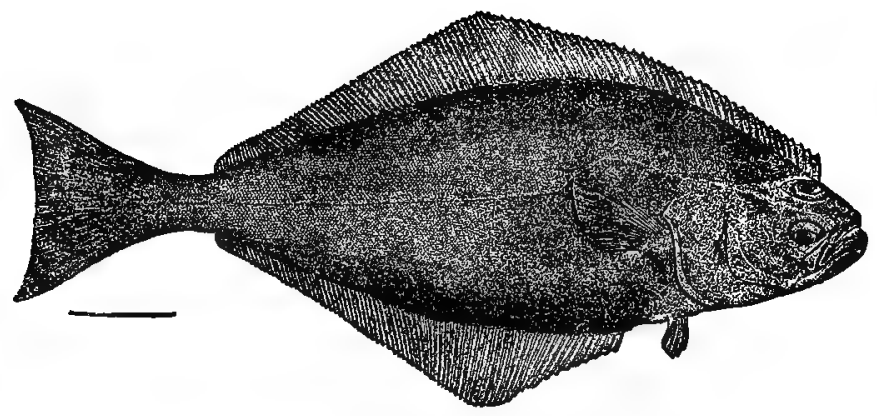

HALIBUT

Hippoglossus hippoglossus

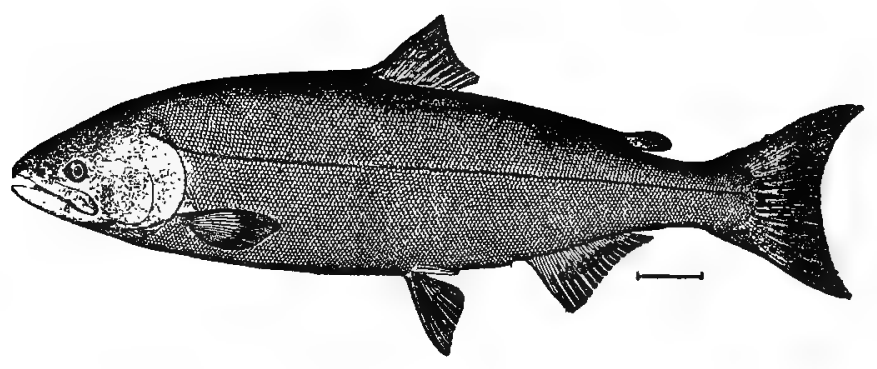

CHINOOK, KING, OR QUINNAT SALMON

Oncorhynchus chonicho 

and unconventional position. I had hooked the sockdolliger before a witness who had proclaimed it on the high seas, and I readily understood why he was so anxious to take the line, - he wished the credit. His argument that it might be a fivehundred-pound fish, which would be valuable to him, and that he knew just how to manage "such critters," fell on deaf ears. I had chartered the craft and skipper, the sockdolliger was my prerogative, and I ordered the envious boatman to haul in the float anchor, and taking my place in the stern of the dory prepared to land the fish if it took all summer. It is unnecessary to go into the details of this experience, needless to say that the fish plunged to the bottom again; it had come to the surface merely to "size me up," and had returned satisfied that it was merely a question of time with me. I had lifted sulking turtles on the Florida reef; had toiled with the big sunfish, side on; had labored with rays from the manta down; and had lifted seeming tons of coral when fishing for red snappers in the Gulf ; but all these "sulkers" seemed combined in this mighty fish, which moved slowly on, taking line foot by foot with such regularity that I began to realize that it was tipping over the side of some submarine hill and going 
down into the deep valley of Despair. My boatman lighted his pipe and asked me what I was going to do when the remaining fifty feet of line had disappeared. He was clearly in the sarcastic stage, and I retorted by suggesting that he take the oars and see what could be done. This stopped the run, and by the most heroic and muscle-rending labor I gained twenty feet on the line, then lay back while that awful weight dragged and surged and took the dory down deeper and deeper.

"Any of your folks ever have shocks?" sententiously asked my companion.

I ignored the suggestion and held back with desperation and hauled in vain; inch by inch, foot by foot, the fish took the line, and it gradually dawned upon me that the real fisherman was at the other end; the sockdolliger had indeed "sized me up," and was playing me. It jerked my arms almost out, took the skin from my fingers; it pulled me this way and that while ambling along, now stopping to hammer me with sturdy blows, then putting on a strain that nearly lifted me from my seat, and the iron entered my soul as I realized that I would have to ask for assistance. If I could only have gotten rid of the fish in 
some other way! If a shark would only take it; if the line would only break, or the hook ; but nothing of the kind happened, the sockdolliger was evidently enjoying itself, the season for man-fish.. ing had opened well, and the anglers among the cod, haddock, lings, and halibuts were doubtless watching the sport with open-eyed admiration at the skill with which the game in a boat was being played and made miserable. The end was near. My "second wind" had come and gone, there was no hope in sight, and theoretically I began to look for a "soft place to fall." I believe this is the correct expression.

"How much did you say this fish is worth?" I gasped, bracing my feet against the rail during a particularly heavy plunge.

"Why, I calculate a big fish like that's worth twenty dollars," was the reply.

"If that's the case, take the line," I said, to show my magnanimity.

"Oh, I don't want to spoil your sport," rejoined the boatman.

"That's all right," said I, airily. "I've taken the freshness out of him." How I wished I had! How I despised that sullen brute at the bottom of the sea! 
The boatman deliberately knocked the ashes out of his pipe, rolled up his sleeves, looked around the points of the compass, and then taking his place by my side picked up the line, while I went forward, took the oars, and prepared to enjoy his agony. At that precise moment the boatman attempted to haul vigorously and broke the line. It was cowardly, but I could not resist remarking, "You don't seem to understand these big fish," to which there was no answer. The fisherman couldn't do it justice and stood silent, merely looking at me.

This being a sockdolliger, it is an easy matter to estimate its weight, which was between five and six hundred pounds; at least the great halibut of these waters (Hippoglossus hippoglossus, Linn.) is known to attain this weight, and so far as mere size and strength are concerned, ranks with the tarpon, tuna, the great South American arapaima, and other huge fishes. It was very evident that could a medium-sized fish be found and hooked in shallow water, it would afford no little sport. As to the actual maximum size of this fish, Nilsson reports one from the Swedish coast which weighed seven hundred and twenty pounds; and Gloucester fishermen have a record 
of one taken at New Ledge, sixty miles southeast of Portland, Maine, which weighed six hundred pounds. I was told at Boothbay, near which the Cunner Club, to which I was once "grand chummer," was wont to meet, that a dead halibut had been found which weighed nearly six hundred and forty pounds, which was the record fish of New England waters. One of the largest halibuts ever brought into Gloucester weighed but three hundred and eighty pounds, and many catches have been made of over three hundred and fifty pounds. The fish of this weight are over seven or eight feet in length, and from three and a half to four feet in width, most difficult creatures to lift when the broad back is presented to the fisherman one hundred or more feet above.

On the North Pacific coast this fish is common, and is occasionally followed by Americans for sport. A friend who accompanied some Alaska fishermen offshore informed me that it was an exciting but very "damp pastime." The hook which these Indians use for halibut, one of which I have in my possession, is a most extraordinary object; few who have seen it understood its nature, as it resembles a wooden god, half being the totem of the tribe, and the barbless 
hook being in the most impossible and out-of-theway position.

If the capture of the great halibut is strenuous, there is one of the group which has afforded me all the gratification of a thoroughly game fish, for which reason is the flatfish, with "eyes distorted," admitted to this honorable company of game fishes. The islands of Southern California lie, as a rule, parallel to the mainland coast, long mountain ranges, - recumbent sea-monsters from seven to twenty-five miles in length, - lying at the surface twenty miles offshore; and as the prevailing wind is from the west, they have a perfect lee on the eastern shore, a region of calms, while on the west other conditions hold. At Santa Catalina, on the south and west coast, the sea often beats wildly against abrupt cliffs, which in storms hurl it back with loud discordant sounds. Coming down this coast one day from the black sea-bass fishing-grounds, we sighted, well in the surf, a school of fishes of large size, tossing the water in air, striking heavy blows, and evidently playing havoc with the small fry which, in rows of gleaming silver, shot from the water. I was trolling with a fifteen-ounce greenheart rod seven and a half feet long, hoping to pick 
up a stray white sea-bass; hence, was ready for the sport, and while I reeled in, the boatman backed into the surf as far as safety permitted, and held the boat head on to the not high seas, shooting ahead when they threatened to break, to drop back when they passed, allowing me to drop my small bait directly in the storm centre alongshore. On the instant came the strike, and as the light boat went careening over a breaking sea, I hooked the fish and presently was playing it from a fairly smooth vantage ground. My boatman suggested large rock-bass, but I was positive I had seen a flat tail waved in the air, and my inference was correct as a halibut came fluttering along the surface with a curious undulating movement for a moment, as though led by a line; then realizing that it was hooked, it plunged down and ran away with my line while the reel made wild music, ran away so effectually that I thought it would be exhausted, dashing by the kelp bed, disdaining this refuge which the black sea-bass always affects, and swimming for open water to make a splendid play, surging on the line that hissed like a knife as it cut the surface-now deep in the heart of the waters, rising with a singular bounding motion to encircle 
the boat, and as suddenly plunge down to sulk in angry protest and apparently present its broad surface against the rod, making the turning of the reel almost an impossibility.

Slowly the boatman rowed out of the surf, and if this fish could have been played in water as shallow as that familiar to the salmon angler, where its rushes would have been off instead of down, it would have commended itself to the ardent lover of purely game fishes. For fifteen minutes it fought me, and until I brought it within eyesight, my boatman insisted that it was a yellowtail - one of the most powerful and hardest fighting of all fishes; but it was a halibut, one of the despised flounder tribe which appeal to the digestion but not to an appetite whetted for sport. This gamy creature redoubled its fighting as it saw the boat, repeatedly broke away, and when gaffed was making a flying rush around the boat after various attempts to hold it; and when finally held, its white belly blazing in the sunlight, beat the water with powerful blows, and literally hurled watery defiance in our faces. When the boatman held the fish up, that I might observe its fine proportions, it was evident that it was built for such work and was an animated 
resistant. The fish, which was the bastard halibut, Paralichthys californicus, weighed between fifty and sixty pounds, was three and a half feet in length, a fine specimen of this genus common about the islands, though rarely caught of this size, possibly because bottom-fishing is seldom indulged in here except by professional fishermen on the so-called grouper banks. At Catalina Harbor, a California fjord, Empire Landing, and a few localities on the west coast, it can always be found. At San Clemente, twenty miles to the southwest, it is also common, and it is also taken at Coronado, in the bay, at La Jolla, San Juan, Monterey, in fact anywhere alongshore where shallow and protected water is found. The young fishes, when lying on the sandy bottom, so simulate it that it is almost impossible to distinguish them. I have taken them from the beach with an eight-ounce split bamboo, and found the sport enjoyable.

Of all fishes this group is perhaps the quaintest. When young they swim upright, as do others, but as they grow they fall over and lie flat, the lower side turning white as the pigment is found unnecessary, and then comes a change which, in its seeming impossibility, equals the 
most improbable fish story. The under eye begins to move, literally starts upon its travels, differing some in the various species in route and method of procedure, but moving, nevertheless, passing around in some, directly through the head in others, until in the adult fish we find both eyes on top, having travelled around from the left to the right side. I am indebted to Dr. Alexander Agassiz for a drawing showing the various stages of this remarkable journey of an eye. Nearly all these fishes commend themselves to the epicure, - the English sole, California sand dab, the New England turbot, the summer flounder, and many more being extremely valuable. The halibut of the Northwest coast has a pronounced economic value, and the "Halibut Express" from Vancouver to Boston is suggestive that the eastern coast cannot supply the demand. 


\section{CHAPTER XXVI}

THE LEAPING SHARKS

"Toward the sea turning my troubled eye

I saw the fish (if fish I may it cleepe)

That makes the sea before his face to flye."

- SPENSER.

IT requires more than ordinary temerity with an audience of anglers, to admit, even by inference, the shark to the select and honorable company of game fishes. I do not propose to commit this possible solecism, but merely to describe the play and action under restraint, of several sharks which I have caught, and others which I have seen caught, and leave the question, game or vermin? to the reader.

It has so happened that I have passed many seasons, winter and summer, in what might be termed "shark countries," that is, localities where the shark was always a factor to be considered. If a tarpon was played long enough to permit its blood to tint the water and reach away, 
a shark, like a hound, would follow it up and rise from the sea, shaking the fish in one's very face. I have had them on the extreme outer Florida reef, about my boat by the dozen, chasing the large barracuda that I had been playing, snatching it from the line, leaving me the head, perhaps, as a reminder that they were not altogether graceless. So plentiful were they, that I often fished for them single-handed, or with a companion, in a small boat; under such conditions a ten or twelve foot shark has the advantage, and on the Florida reef I frequently cut away, rather than be towed out to sea by some unseen monster.

Shark-fishing is a legitimate sport if the participator will approach the game fairly, and some of the most exciting days of my life have been passed on the Florida Keys or at the mouth of the St. Johns River in the shad season, where, alone, I endeavored to master large sharks; and I can commend the exercise to the man of sedentary pursuits.

There are two sharks which, in their play when hooked, are remarkable imitations of certain game fishes which deserve the attention of anglers. One of these is very common at Aransas Pass, 
Texas, and I have taken a similar shark from the beach of Loggerhead Key on the extreme outer reef. In the summer of 1902 I was fishing for tarpon at Aransas, and one day after making several catches I had my boatman row me to the vicinity of some fellow-anglers, hoping to photograph a tarpon in mid-air, - a feat that has been accomplished by Dr. Howe of Mexico, who at Tampico, the centre of the winter tarpon-fishing, succeeded in inventing a gun camera which accomplishes this work. While watching the leaps of the fishes, and snapping a kodak at them, generally taking the sky, the sun, and nothing else, I observed a fine leap accompanied by a most energetic thrashing in the air. The fish left the water bodily, and when three feet above the surface seemed to lash itself into a perfect curve before it descended, hardly touching the water before it went into the air again. I assumed it to be a very gamy tarpon, perhaps what was known here as "Yucatan Bill," a wily, long, slender tarpon, a "Yucatan bounder" that was supposed to return to this locality every summer for the purpose of amusing itself with certain innocent anglers. The "bounder" had broken lines and rods, shattered chairs, broken oars, 
towed boats down into the breakers opposite the jetty, and literally played havoc with the fishing fraternity, and as yet was uncaught.

I had been regaled with descriptions of this fish by the veracious wags of Tarpon Inn, who pictured him with scales as large as a dinner plate, a mouth full of big hooks, and wire which hung like a beard, and naturally thought it not improbable that my companion was being initiated by "Yucatan Bill"; hence I watched the play with much attention. Never did tarpon leap with more force or with greater zest than did this fish. Up into the air it went, whirling about, now landing on its head, now coming down broadside on, making a wave of foam, then stopping to rush to one side and encircle the boat; always fighting, bearing off with a force that kept the stiff rod of the angler bent and the reel screaming. For twenty minutes at least I watched the play, and then, to my amazement, saw the successful angler cut away the game, and later heard his shout that it was a "leaping shark."

I had been keeping out of the way that I might not interfere with the play of the game, hence had not recognized the outline of the fish. The ha- 
bitués of Aransas considered this shark essentially game. It was included among the "game fishes" caught by the members of the Tarpon Club, and certainly deserves the honor and the appellation if one can throw off the inherent dislike to sharks which holds with nearly all anglers. A similar leaping shark was not uncommon at Garden Key. I have had them leap out of the water, the entire body except the tail being clear, the subsequent rushes challenging admiration. In a word, the shark was gamy and a hard fighter; but when it came up snapping and biting at oars and gaff, and its disagreeable half-musky odor pervaded the air, only a shark after all, one's enthusiasm paled. At Catalina Harbor, on the island of that name, at its very head where the water is not over three or four feet in depth, is the breeding-ground of a small and attractive tiger shark, known to science as Galeorhinus. In July and August they are found here in such numbers that the water within a few feet of the shore appears to be fairly bristling with large dorsal fins. It chanced that I strolled up the beach one day with a light rod and hired an old fisherman to take my heavy bait out into the bay that I might hurl back the banter of a companion who 
doubted my ability to land one of the sharks with my light rod and number twelve line. In a short time I had a strike, and upon hooking the game, up into the air it went, clear of the water, a mauve-colored creature beautifully striped and gracefully formed, to fall with a crash and dash up the beach at a speed that rapidly exhausted my line and forced me to run along the sands some distance before I succeeded in turning and stopping the shark, which had reached fairly deep water, and was making a most creditable fight, bearing off heavily, darting from side to side, and now and then rising into the air and shaking itself bravely. Had it not been a shark, the miserable scavenger of the sea, the cousin of the tarpon killer, it might have been considered a very gamy fish, as for fifteen minutes it defied my efforts to bring it to gaff, coming in then reluctantly, being gaffed in an extremely gallant manner by a fair angler of the party. This shark measured nearly five feet in length, and weighed sixty pounds. The leaping habit is common to the species, at least in this locality.

The sharks which have been taken in various localities with the rod and very light lines often surprise the layman by their size, girth, and fight- 
ing qualities. Along the mouth of the St. Johns and from the beaches of the Florida Keys I have enjoyed many a bout with these doughty ruffians of the deep. I once hooked a large tiger shark, picking it out from a school which I had baited around the boat, and as it started off towing the boat, numbers of these ugly creatures followed me, some on one side of the bow, some on the other, and others just below and not five feet from the surface-a menacing contingent. Out of scores of sharks of different kinds which I have taken in the Atlantic, the Mexican Gulf, and the Pacific I would award the palm for hard fighting and strength in proportion to its size to the hammerhead, two of which I once saw off Capes Charles and Henry in the mouth of the Chesapeake, which were not less than fifteen feet in length. I have hooked them in the Pacific and played them with the rod, but have never landed a large one in this way. Other anglers have played them longer and seemed on the very verge of victory, but so far as I am aware no one has conquered a large hammerhead with a rod. To illustrate the courage and pugnacity and thorough fighting qualities of this shark, which is a foeman well deserving the attention of him who delights in 
hard and closely contested hand-to-hand struggles, I may describe a certain catch made by me off Catalina Island. I was fishing for whitefish with a light rod when something took the bait and cleverly cut the wire leader; the next moment the enormous fin of a shark appeared alongside the small boat and began to circle around it, so near that I could have touched it. My companion was demoralized, and demanded to be landed upon the rocks hard by. This accomplished, I returned and the shark took three baited hooks as fast as I could renew the bait and cast them; when I hooked it, it merely turned its head, cutting the hook or wire. It was apparently between nine and ten feet in length, and I could plainly see the extraordinary hammerlike head with the eyes upon the ends, hypnotic and ugly. Near me was a boat in which were two Germans fishing, and as they landed a fish they hung it upon a string overboard. This now attracted the shark. I called to them and they jerked the string of fish into the boat, not a moment too soon to save it. The disappointed and hungry fish darted about the boat, striking it with its big dorsal fin, so terrifying the men, who doubtless had never before seen a shark, that they lay down 
in the bottom of the boat; presently I saw the barrel of a rifle, and one of the men began pumping bullets at the big creature, some of which must have taken effect, as it swam off, but still on the surface, its dorsal fin looking like a miniature lateen sail.

I determined, if possible, to catch the shark, and followed it into the bay of Avalon, and while I hurried inshore to get a shark line it dashed into a fleet of small boats and endeavored to steal the fish. When I again reached my boat, which was a two-hundred-pound, flat-bottomed skiff, I found that the hammerhead was still swimming about, defying the entire floating community. The boats were following it, men shooting at it with revolvers, or striking at it with oars and boat-hooks; but I could not see that it paid any attention to these attacks except now to continue around the shore and so out of the bay on the opposite side. I had secured a long cod line with a jewfish hook, which I had baited with a ten-pound fish, coiling the line astern. A fresh companion rowed me directly out of the bay in order, if possible, to intercept the animal, and in ten minutes we were in its path. As it came on, I swung the bait at it. There was a swirl of 
waters, the line tautened, and allowing a few sećonds to pass, and as many feet of line to glide over, I jerked the hook into the shark. With all my care I was hauled to my knees, losing the line which rose from the carefully laid coil like a living thing. We were in water two hundred feet deep, and before I realized it the line was exhausted, and no flat-bottomed, broad-sterned skiff ever came so near being literally dragged bodily under water as did this. My boatman was utterly demoralized, and more than once I pressed the open knife which I had ready, upon the line, as the boat sank to the danger line.

All this time the boat was moving directly out into the channel, carrying a big wave beneath her, the shark having sounded like a whale, the line being so stiff and taut that I could not move it. My companion now shipped the oars and held them, trying to row; but this had no effect, and the shark towed us a mile at the top of its speed before I made any impression on the line, and then it became evident that we should have to cut line or gain on the fish; so I manned the line and hauled, leading the line forward between my feet, my companion coiling it as I hauled, the boat being so light and unstable that but one 
could work. It was most difficult and laborious work, - I will not call it sport, — though in its excitement and danger there was enjoyment of a certain kind, and time and again the lusty shark tore the line from my hands and threatened to sink us; but after half an hour I had it in hand. When it lunged I lay back and held on with my knife between my teeth, and presently found that I could hold it; hence the strength of the shark was on the wane, whereupon I played it with renewed courage, hauling it as rapidly as possible, holding hard when it rushed; in this way I soon brought the shark so near the surface that in glancing over the stern I could see it circling below. Looking back at the distant bay I saw that we were followed by a number of boats, yet we were still being towed at such a pace that the men had to pull at full speed to catch up to us, and by the time the first boat came up and threw us a line I had the shark within ten feet and saw that I could hold it; but it was evident that two skiffs were not a match for this doughty game, and it was not until five boats were in line, and ten oars pulling against it, that the victorious flotilla began to move inshore. The shark's head was now partly out of water, 
and I was holding it by the hammerlike projections while it writhed and lunged. In this manner this hard-fighting, gamy shark was towed in, its courtiers, the black remoras, clinging to it even when twenty men seized the line and drew the struggling animal upon the sands, a type of the utterly fearless brute of the sea-an animal that defied scores of men, swimming among their boats, paying no attention to bullet or club, sailing about with complete indifference, only going down before superior numbers. 


\section{CHAPTER XXVII}

\section{THE CHINOOK OF MONTEREY}

"Here, when the labouring fish at the foot arrive, And knows that by his strength but vainly doth he strive, His tail takes in his teeth; and bending like a bow ${ }^{1}$ That's to the compass drawn, aloft himself doth throw; Then springing with his tail, as doth a little wand That bended, end to end, and flirted from the hand, Far off itself doth cast; so doth the salmon vaut. And if at first he fail, his second somersaut He instantly assays, and from his nimble ring Still yesting, never leaves until himself he fling Above the streamful top of the surrounding heap."

THERE are many reasons why the sea-angler is a very lucky personage. One is, that often, when fishing, he has the charms and delights of both sea and forest, and nowhere is this better exemplified than at Monterey, the old California town so rich in historic associations. Here, or in the adjacent waters, is the true home of the chinook

1 This explanation of the leap of the salmon was entertained by some writers within the last fifty years. 
salmon, the gallant high jumper, the ultima thule of the angler's dreams and hopes, the Oncorhynchus tschawytscha of science. No more attractive country can be imagined than that contiguous to the waters of the bay of Monterey where it reaches north to Santa Cruz and south to the bay of Carmel, of happy days, with its old mission, its trout streams, and charming coast line, a natural park, to linger long in the memory. It appeals to the angler in many ways, and one can readily understand why the old Spaniards selected this spot as their stronghold in the north.

It is generally believed on the Pacific coast that, as a rule, the salmon will not rise to a fly, and it has passed into angling history that we owe our possession of Alaska to this fact; for did not a certain British admiral of sporting proclivities say when the question was being discussed by the nations of the world, "Oh, let the Yankees have it, the salmon won't take a fly!" And did not the English press immediately drop the show of opposition to the purchase which it had made? If angling history is to be believed, it did. Dr. Jordan states: "The chinook salmon does not take the hook [probably meaning fly] when in fresh water, though it is occasionally taken on the 
trolling spoon;" and the dean of this particular sport on the Pacific coast, Mr. J. Parker Whitney, writes: "None of the Pacific coast salmon take the fly. There may be isolated cases, but few and far between." One of these cases fell to the luck of Rudyard Kipling, who acquired merit in the eyes of all lovers of angling in an article to the Pittsburgh Dispatch, writing delightfully on his experiences: "The next cast, ah, the pride of it, the regal splendor of it, the thrill that ran down from finger-tip to toe. Then the water boiled. He broke for the fly and got it." Not alone with fly, but with spoon, did the genial poet conjure the gamy chinooks. Listen: "How shall I tell the glories of that day? Again and again did California and I prance down that reach to the little bay, each with a salmon in tow, and land him in the shallows. Then Portland took my rod and caught some ten-pounders, and my spoon was carried away by an unknown leviathan." Ah, that you and I could have been on the Clackamas when "Portland held the gaff and the whiskey," and Kipling held the rod. Happy "Portland"! lucky Kipling! what tales he must have told at night to "California," of the mighty Mahseer and the 
heathen but gamy Rohu; ah, the very thought of it! May good luck always avert calamity when he is fishing, be it on the Clackamas, Indus, or Irrawaddy.

Despite this unbending of the chinook to Kipling on the Clackamas, the sport with the fly on the Pacific slope is so uncertain that few anglers attempt it, and the principal salmon-fishing is in the waters of Santa Cruz, Monterey, and Carmel bays, where the splendid fish is certainly at home and affords sport of an exalted kind. Who landed the first salmon here is unknown to fame; but the angler who has made the sport the closest study is Mr. J. Parker Whitney of New York, who well deserves the following encomium from some appreciative brother angler, which I find in the Forest and Stream of Sept. 2, I893: "Salmon fishermen the world over owe a debt of gratitude to Mr. J. Parker Whitney for his extremely interesting accounts of sea-fishing for salmon on the Pacific coast. Though that fishing has been known for years to a limited number of anglers, Mr. Whitney, as the first one to exploit the sport in an adequate description for the benefit of the guild, may fairly lay claim to its discovery. Others may have known of it as the Norsemen 




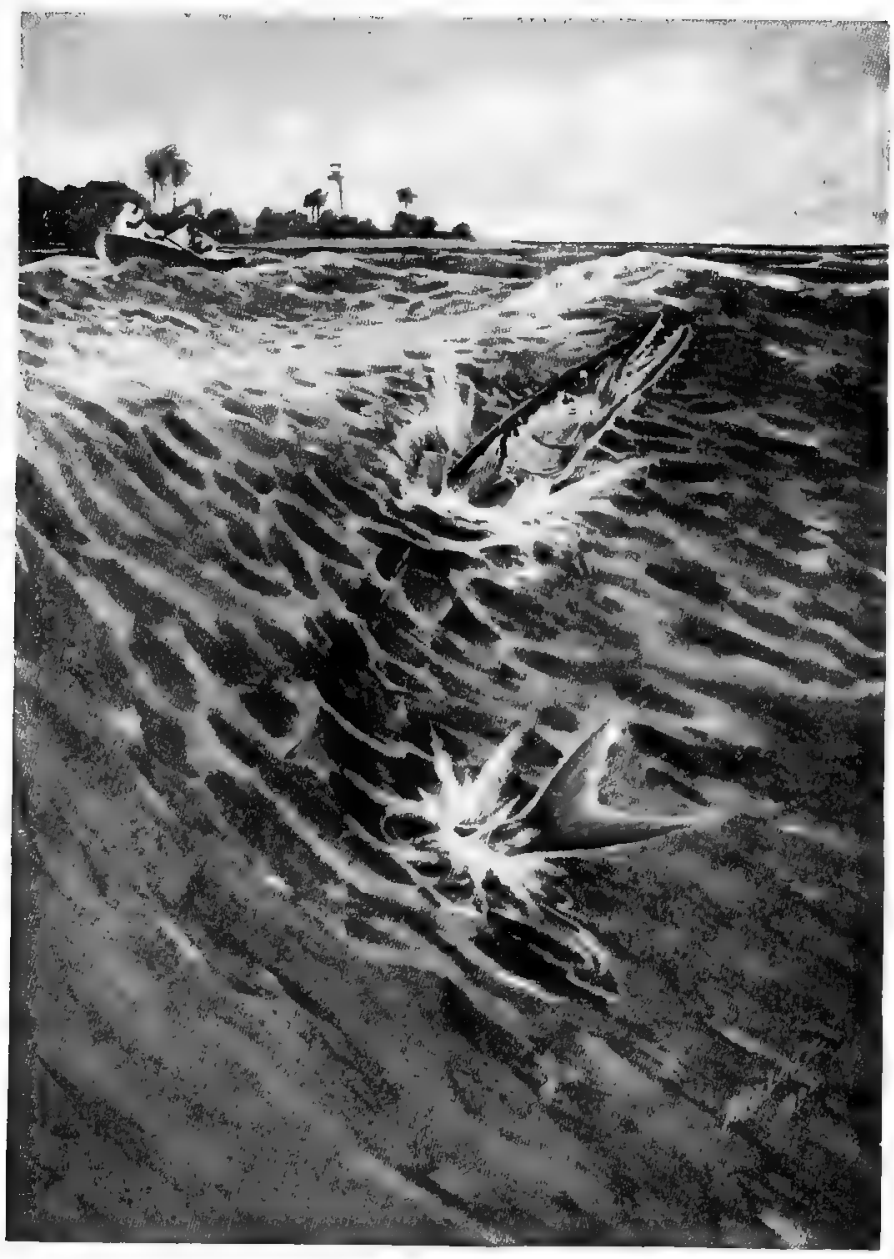



knew of America; Mr. Whitney has been the Columbus to proclaim the discovery to the world, and to command for it the attention it deserves."

As salmon-fishing the world over is in streams, from the beautiful pools of Canada and Maine to those of Scotland, the fish has come to be known as a fresh-water denizen. It is rarely thought of as an inhabitant of the ocean, yet the cool water of the Kuroshiwo, which sweeps down the northwest coast, is doubtless its home, and it goes up the streams but to deposit its eggs and die. Salmonfishing par excellence, with the fly, as well as the habits of the fish, is fully described in another volume of this series, hence I shall merely refer to the sport as it is found in salt water. The salmon live somewhere offshore all winter, - exactly where, is not known; but it is the belief of anglers that they do not stray to any great distance from the shore, probably haunting some bank where the herring and anchovies roam in winter. In spring they move north, or in, and by the last of May, - sometimes sooner, sometimes later, and generally about June $15^{\text {th }}$, - they enter the bays of Santa Cruz, Monterey, and Carmel, chasing in the great schools of herring, squid, and anchovies. For weeks the professional fishermen 
have been on the lookout for them, and when the assurance is given, telegrams to San Francisco, New York, and other places are sent, and anglers, devotees to this sport, are soon speeding to the various points, and the season begins.

The professional fishermen have no sentiment, and it seems a carnal sin to see hundreds of the finest fish. jerked in with literal ropes and beaten about the head with sinkers weighing a pound or more. They troll for them with heavy lines down thirty or forty feet, where the gamy fish bite eagerly at smelt or herring; and the men in the course of the season reap a rich harvest. The sportsman will have none of this; he approaches the game with all the deference worthy the king of game fishes. The angler who would take the salmon in its home must discard all the preconceived ideas he may have had from experience or reading regarding salmon in the rivers of the East, as it is another matter here and to all intents and purposes another fish; and the non-multiplying salmon reel, the delicate line, and long, beautifully bending rod are worse than useless, though it would be an interesting experiment to try this tackle on the fish in its haunts in the open sea. The tackle I would suggest is a rod of split bam- 


\section{The Cbinook of Monterey}

boo almost identical with that used for yellowtail, or a good noib-wood rod and long tip not to weigh over twenty-six ounces and between seven and eight and a half feet long, a number twelve or eighteen cuttyhunk line, with a 7/0 O'Shaughnessy hook and short wire leader with two swivels, baited with a three or four inch sardine or smelt. The angler trolls slowly, with bait twenty or thirty feet down, or at times he may try the surface with good luck; but a sinker, as a rule, is an essential. Mr. Hermann Oelrichs, a well-known expert in this sport, who has landed four hundred and fifty pounds of salmon in one fair morning off Monterey, representing thirteen fish, uses a seven-foot rod with ample reel. Mr. J. Parker Whitney, according to the Sunset Magazine, fishes with a steel Bristol trolling rod seven and a half feet in length, weighing but eleven ounces. His line is a linen sea-bass, number eighteen, with a large multiplying reel holding five hundred feet. His hook is a large Kirby soldered to a brass wire with a linked wire leader about a foot in length, all connected by swivels. The sinker weighs four ounces. With this outfit, with smelt bait, fishing thirty feet down, Mr. Whitney has had phenomenal luck, averaging eight salmon a day; the weight 
of his first sixty-nine fish, according to the authority quoted, being eleven hundred and thirty-three pounds, or an average of sixteen pounds each. The smallest fish weighed two pounds, the largest fifty-four; and that Mr. Whitney's methods are eminently successful it need only be said that his catch to date numbers four hundred salmon. Such are typical outfits by well-known anglers who have fished these waters for years, and many others may be seen on the grounds; all of which points to the moral that the typical fly-casting salmon rod is out of place.

Thus equipped, we may steal out of Monterey some morning before daylight, tool down the seventeen-mile drive to the melody of the surf as it piles in upon the rocks, finally reaching Carmel Bay before sunrise, or just as the sun is coming up over the distant Sierras, a ball of crimson. We have made arrangements for a boat, and the boatman is waiting; and in a few moments we are drifting over as fair a sheet of water as I have seen, one that with the charming surroundings must appeal to the most phlegmatic nature. The open bay is like a lake, save where some affrighted anchovies are rushing, or some vagrant finny sunworshipper rises in air to greet its mistress. A 
shining sardine is fastened on the hook; the line twenty feet from the hook is looped for a few inches and held in place by a thread upon which is hung a pipe sinker, - that is, a sinker two or three inches long, slender and perforated; the loop and thread should be very little longer than the sinker. The philosophy of this is apparent when the strike comes, as the full force will come upon the thread, which, when it breaks, liberates the sinker, giving the angler the fish alone to play without the leaden annoyance. Mr. Whitney has made an improvement on this device, often used in seaangling, which is as follows, and which I take the liberty of copying from his valuable article in the Sunset Magazine:-

"I have lately adopted a better method of attaching and liberating the sinker, by having the four-ounce lead round in tapering form with a small ring soldered in one end; up the line six feet from the hook and part of it I tie in two swivels nine inches apart. I then tie a short piece of weak cotton twine to the bottom ring of the upper swivel and to the upper ring of the swivel below, having threaded the cotton twine through the ring of the sinker; shorten the cotton twine to four inches in length between the two 
swivels, which loops up four or five inches of the regular linen line. The salmon, striking and holding the baited hook and giving the consequent strong pull, breaks the cotton line, and the sinker, liberated and of light value, drops away in the sea, leaving the salmon free and unimpeded for his vigorous and gallant fight, except for the fine line and rod strain."

As in white sea-bass fishing, the game is often discovered by the birds, shags and others, which are plunging down and swimming through schools of anchovies, playing havoc with the small fry, beneath which the hungry salmon often lie like these bass, picking off the stragglers, or at times chasing and driving them in upon the rocks or into the surf. On this day the fish bite well, and the angler's patience is not exhausted. The strike comes, and if you are an old salmon fisherman from the Restigouche country or elsewhere, this doughty chinook will treat you to some remarkable surprises and possibly to a new sensation. What is the splendid creature that seizes the bait and shakes and worries the line like a bull terrier, giving blow for blow; this tremendous surge down, down, deep into the heart of the bay, with irresistible force? Surely this is not the fish, or 
its cousin, that you have cast flies for in some Eastern pool, but a deeper sulker, a down-plunger, as there is water in which to plunge, calling to mind the yellowtail, and illustrating the point that almost any fish when hooked will "sound" if the water is deep; and I venture the statement that if tarpon were not taken in shallow water they would not leap so well or so continuously. They leap partly because they cannot go down to any great depth; and if the tuna could be taken in water twenty feet deep I am confident that it would dash into the air and take its place with the ten-pounder, tarpon, leaping shark, black bass, kingfish, and others which leap at the strike. Mr. H. Gray Griswold endeavored to test this with the tuna by towing one into shallow water, but doubtless the fish by this time was too fatigued to leap.

Our sulking salmon is raised by pumping and other means, and when it nears the surface bears off, running and making a gallant fight. But possibly a soupcon of disappointment enters the soul of the angler at the few leaps of the salmon, but wait. As the noble fish comes up and the gaffer fingers his weapon, the salmon springs into activity, the reel screams ze-e-e-e-e-e-e-e-e, a long 
wail. Did ever a salmon of the pool make so splendid a rush? Your line is melting like the snow on the distant Sierras in this morning sun. You have been playing the fish for ten minutes, but the sport has just begun, and two hundred feet, perhaps three hundred, away, after a desperate leap, the chief of the chinooks is hammering away, dealing you lusty blows, and preparing to dive deep into the azure waters. Down it plunges. You feel the throbbing of the line, and reel and lift, making line slowly against this marvel of game fishes which, when again at the surface, alternately rushes and plunges, and sometimes - tell it not in Gath!-hurls the hook from its jaws, to eye you a second and slowly disappear. But you wear the talisman of good luck, and the gallant salmon comes in, fighting every inch, a splendid quarry, the type of all that is best in the angler's score, a perfect game fish in play and edible quality.

On such a day and in this very place, Mr. Whitney took twenty-seven salmon from daylight to five o'clock in the afternoon, weighing four hundred and eighty-two pounds, a record which if it has been exceeded in the beautiful bay of Carmel has not been recorded. I can conceive 
of no more attractive salmon fishing ground than this or Monterey bay, and in the vicinity are some of the finest trout streams in California, Carmel River running up into the Coast Range with sixty-five miles of fishing, and entering the bay near the old mission. Not far away is the Del Monte preserve of twelve thousand acres for sportsmen, well stocked and well protected, and along the upper banks of the Carmel one finds the Potrero, Garcia Creek, the San Clemente, the Dionicio, the Cachagua, the Chupines, - all suggestive that the salmon angler has but to row ashore at the old Carmel mission, and in the same day transfer his allegiance to the trout, the gamy cousin of the salmon of the deep sea, and wander through some of the most charming regions of northern California, sylvan scenes so opposite to those which form the background of salmon-fishing that one may well doubt that the limitless Pacific rolls and stretches away so near that its voice blends with the song of birds and the rustle of forest leaves.

Santa Cruz, an attractive town several miles north of Monterey, is equally famous for its salmon, and near one of the noblest forests of the world, while the bay of Monterey is an attractive and 
prolific fishing ground, better known and more often fished than Carmel. The salmon in its habits presents many remarkable features-living in the ocean in its adult stage; taking to rivers to spawn; impelled by a marvellous instinct to seek the high waters of streams; leaping high falls; swimming up cascades which would be considered impossible had not the leap been seen, photographed, and measured; overcoming all obstacles, to reach at last a spot hundreds of miles from the winter home, to deposit their eggs only to die. The movement of these fishes, their remarkable ascent of streams, in fact, the complete cycle of their lives, with their many conditions, constitute one of the most fascinating pages in the history of game fishes of fresh or saline water. 


\section{CHAPTER XXVIII}

\section{GAME FISHES OF THE COLONIES}

THE colonial possessions of this country, especially those of the Pacific, abound in a number of interesting fishes which, when thoroughly investigated, will doubtless add to the list of large American game fishes available to anglers. Very little attention has been paid to angling as a sport either in Hawaii or the Philippines, and as in the present volume I have confined my description of catches to those personally made, I shall pass them with but brief reference, and turn to the game fishes of Porto Rico, all of which I have brought to gaff or net.

About Honolulu the opah, referred to in a previous chapter, is taken, and I have seen a photograph of a large specimen of this fish claimed to have been taken in these waters with rod and reel. Dr. Jordan, who in I 902 made a visit to Samoa and the islands, wrote me: "Game fishing is almost unknown about the islands, 
although there are a great many fishes - probably two hundred species - which take the hook and might come under that head. There are several large species of Caranx, but we are not sure what any of them are." This latter genus includes the jacks or crevalle of our southern waters, which undoubtedly would afford good sport. An eastern angler, whose name I have unfortunately mislaid, showed me a photograph of a large fish which weighed at least one hundred and fifty pounds, taken at one of the Hawaiian Islands with rod and reel, which he claimed was as gamy as the tuna. I recognized in this fish a very rare and interesting species, one specimen of which has been found at Santa Catalina, which weighed about fifty pounds. Dr. Charles H. Gilbert of Stanford University kindly identified this latter specimen for me and wrote regarding it: "I find now that it represents an undoubted specimen of a form hitherto known only from the Mediterranean and neighboring waters (Luvarus imperialis). It is said to be rare in its home waters, and is as yet unreported from our Atlantic coast."

This fish bore a striking resemblance to the " jack," but was very large and powerful, and if 
available to anglers would doubtless take its place with the tarpon, tuna, and other big game of undoubted standing.

So far as the angler is concerned, our new colony Porto Rico presents a field that can, as regards game, be compared to southern Florida, the environment being more tropical and charming; but the conditions for fishing are in many . respects different and vastly inferior. Porto Rico is about fifteen hundred miles from New York, or it can be reached by train to Florida and boat to Key West or Havana. It has a coast line of three hundred and sixty miles, faces the north bravely, and while tropical, is really cooler than any other island of the group. Frederic A. Ober has explored its waters and mountains and painted its charms perhaps more vividly than any other American. The island is deficient in good harbors, San Juan being the best one on the north, about which some good fishing is to be had; to the westward are found Puerto Real de Cabo Rojo, Añasco, Rincon, Aguadilla, and others available for the angler. On the south side are Ponce, Jobos, Guanica, and many bays and inlets in which the angler with North American tackle will find solace and amusement. There is one 
peculiarity about the island, it is exposed on almost every side to winds and as a result a heavy surf prevails at localities which under other circumstances might afford excellent sport. The angler will find numbers of professional fishermen at San Juan, but no good small boats regularly adapted for sport, sail-boats being used.

Among the fishes the robalo will interest the angler - a gamy creature three or four feet in length, very common here and referred to in a previous chapter. A good ground for it is the Rio Plato and the various lagoons, the fish affecting shallow and smooth water wherever it can be found. Near San Cristobal the jurel and cherna fishing is excellent. The former, Caranx, is a gamy fish though of small size, rarely exceeding two feet in length, but very gamy, as I can testify, having often taken it in Florida waters where the conditions are more favorable, so far as wind is concerned. The cherna next to the tarpon is perhaps the largest game fish found here and very common, large individuals weighing fifty or more pounds. Equally as large, if not larger, is the black grouper, common at many points and a fine fish, especially when it can be found in shallow water. Here is the familiar hogfish, 


\section{Game Fishes of the Colonies}

now known as the perro perro, and often ignominiously caught in pots, and there are a host of bait-eaters, as doncella, a beautiful little parrotfish, chætodonts, and many more. The Porto Rican waters abound in parrot-fishes, found on the coral reef, the cotoro verde, loro colorado, and vieja colorado being particularly common, some attaining a weight of twenty pounds or more. Among them is found the familiar spadefish, here known as paguala, tipping the scales from eight to twenty pounds. The tarpon is a very common fish about Porto Rico, but I cannot learn that any one has ever taken it there for sport, and as the flesh is very poor there is no incentive for the local fishermen to catch the sabalo, as it is sometimes called. Barton W. Evermann, who is the authority on the fishes of Porto Rico, and who has made an elaborate and valuable report to the government on the subject, entitled General Report on the Investigations in Porto Rico of the United States Fish Commission Steamer Fish Hawk, in 1889 , made some interesting discoveries at Hucares relating to the young of the tarpon, finding several young fishes ranging from two to seven inches in length at the former place and at Fajardo. I have made many attempts to learn $2 D$ 
something regarding the breeding habits of this fish, but beyond ascertaining that females taken at Aransas Pass in summer bore spawn, could learn nothing, fishermen at this point never having seen the young. The angler visiting Porto Rico will find another fine game fish, the "ten-pounder," a cousin of the doughty tarpon called here "piojo," "matajuelo real," chiro and "lisa francesa," according to Evermann. For rapidity of motion and remarkable acrobatic feats, this fish stands at the head of all game fishes. The leap of the tarpon is stupendous and impressive, but it is deliberation compared to the erratic and rapid rushes of the ten-pounder. I can only compare the leaps of the fish to an animated flashing beam of silvery light. The first one I hooked dashed out of the water in every possible position, fairly dazzling the eye. At Aransas Pass this fish is very common.

The attractive yellowtail of Florida is found here plentifully and known as the colirubia, a delight giver with light rod.

A number of grunts, Hæmulon, are found in Porto Rico, ronco, arraydo, corocoro, jallao, being some of the Spanish names under which the sailors' choice, the black grunt, striped grunt, and 


\section{Game Fisbes of the Colonies}

margate-fish of Florida are known; but not much can be said for their game qualities, at least in my estimation. They are famous bait-eaters, excellent pan-fishes, and among the loudest of all the grunters, or "talkers," of which there are many among fishes. I well remember the first grunt I ever caught. It was such a good-naturedlooking little creature that I unhooked it carefully, feeling that its large and expressive eyes were watching me with more earnestness than is usual among fishes; and as I held it, it began to grunt, so loudly that I surrendered at once and tossed it overboard, quite convinced that the extraordinary sounds were pleas for mercy. Nearly all of the grunts are attractive, even beautiful fishes, - the common grunt of Porto Rico, Ronco arará, being one of the most striking in its range and combination of color. In some of the parrot-fishes the singular joined teeth are blue or pink, and this quaint and familiar grunt has the inside of its mouth colored a vivid red; and when hooked it comes pleasantly up with its mouth wide open, ready to fairly grunt its way to liberty if the angler is sentimental or soft-hearted, as without doubt certain anglers are. 
An excellent fish here is the pompon, Anisotremus surinamensis, which attains a length of nearly, if not quite, four feet, and bears a superficial resemblance to the drum. Another species, though small, calls to mind the porgy, the profile being vertical, giving the "catalineta" an appearance of solidity and strength. With it is seen the "pluma," or jolt-head porgy, Calamus kendalli, a lusty twelve or fifteen pound fish, capable of making a vigorous fight. Its large head, prominent eyes, and masklike face make it a conspicuous form among the Porto Rican fishes. Porgies have the faculty of expressing their emotions with their dorsal fins to a certain extent, recognized by those who have kept them in confinement. I watched this fish in an enclosed aquarium on the reef for a year. It became very tame, would eat from my hand, and in swimming invariably kept the sharp spines of the dorsal fin flat upon its back; but when I approached, up they would go, and if I made a very quick movement, they would stiffen out like quills upon the fretful porcupine, forcibly reminding spectators of the hair on a cat's back, or the tail of a cat or dog.

The gamy white sea-bass and the weak-fish are 
represented in Porto Rico by the "corvina," Cynoscion jamaicensis. Many striking rays are found about here, the list in all probability being similar to that of Florida. One popularly known as the eagle ray (AEtobatus) is a most graceful and attractive creature, as I recall it, literally flying ahead of my boat over shallow lagoons on the reef, the back dark with vivid light spots - a veritable leopard of the sea. Its side fins move up and down with a singularly graceful movement, the fish appearing to fly along. Trailed behind this birdlike creature is a tail like a whip-lash, longer than the extreme width of the fish, a most dangerous and effective weapon. Just above its base are from one to three spines set one above the other, and about six inches in length, a quarter of an inch in width, and closely serrated. One in my possession, a souvenir of the adventure to follow, is a very good saw if soft wood is employed. If this creature could by any means be considered a game fish, no one capturing it would gainsay it, as a more gallant fighter does not sail the shallow seas, and as a ground and lofty tumbler, a leaper of high degree, it holds high rank. The leap is a most graceful movement, 
and one of these fishes sprang into the air so near my boat at Aransas Pass that I intuitively dodged. Even the big manta, seventeen feet across, leaps, and I have heard the thundering crash of its fall or return, sounding like an explosion on a hot summer night on the Florida reef. One of my boatmen, Paublo by name, a negro prone to the siesta at any and all hours, was very fond of fishing, and frequently when I was fishing for small barracudas from the beach of the Florida Keys, and he had caught my bait, he would fling down his cast-net, take from his pocket a long cotton line, and baited, send it swinging out into the channel; then lying down, crossing one leg over the other, he would take a turn with the line about his big toe, and forthwith fall asleep. On one occasion I heard his yells, and looking back saw him on his back, one leg in the air, being nearly hauled overboard by a large whip ray. I have referred to the whip as a weapon, and a most effective one it was. In poling my dinghy over the reef a companion, who was sitting in the bow with legs overboard, was suddenly struck by a ray which darted up out of the high weed, not only cutting his naked legs, but lacerating his 
foot across the instep with three deep cuts to the bone, made by the serrated spines.

In Porto Rico the kingfish, or "sierra," occurs with the Spanish mackerel and the great picuda, and on the reef the moray, or "morena verde," an ugly creature often six feet in length. One which I inadvertently brought into my boat in Florida charged me so ferociously that I sprang up the mast to avoid it, while my companion went overboard, the water being shallow, leaving the monster in full possession, which finally made its way into the water again.

So far as mere angling is concerned Porto Rico offers no advantage over Florida, indeed, is not to be compared to it. The fishes are about the same. On the reef of the latter the weather conditions are more favorable, the heavy winds which pile the sea in so continuously at Porto Rico are lacking; yet in both localities in midsummer the angler may expect heat of an intense and monotonous variety. 


\section{CHAPTER XXIX}

\section{BAIT AND GROUNDS}

To the sea-angler the bait and often the bait-catcher is an important factor to be considered, especially in Southern seas, on the great reef which reaches out from Cape Florida and trends to the west as though determined in ages to come to enclose the Gulf of Mexico and make it an inland sea. The bait-taker is an interesting personage, and the collection of bait, at least on the reef, a fascinating pastime. Paublo, his naked black shoulders half covered by the castnet slung over them, the heavy sinkers or weights - leaden beads - clanging as he strode along the shore, his keen eyes on the watch for mullets, was a most picturesque figure. The newcomer would wonder who or what he was, as in one hand he bore a huge cimeter-like object with a cloth bound about the end as a handle. With the cast-net he took mullets, bait for barracuda, jack, and amber-jack. With 


\section{Bait and Grounds}

the "sword" he crept upon schools of small sardines or "hard heads," which hugged the shore, and which were intended to lure the gray snapper to its death. Sighting a school, he would drop the cast-net on the sands and wade out into the water knee-deep, then coming slowly in, apparently not moving, creeping upon a brown spot six feet across, directly at the surface. When within reach the cimeter was raised, coming down with terrific force, cutting through the school, and maiming thirty or more fishes, all that were needed. At the upper end of the lagoon, really the interior of a growing atoll, where the water was shallow, the ripple on the surface told of schools of mullets, and the net was taken from his shoulders and manœuvred for several moments as he slowly waded out in their direction. The cast-net when spread out represented a circle from six to ten feet in diameter. The circumference of the circle was lined with lead beads or sinkers, each an inch in length, and from the circumference to the centre extended six or eight stout cords which passed through an orifice lined with leather; these met and joined; to this was fastened another cord eight or ten feet in length: 
Such a contrivance was utterly impossible to a novice, and in my novitiate I afforded the habitués of this portion of the reef no little amusement. I succeeded in catching myself, throwing myself over, and nearly losing my teeth by forgetting to let go at the proper moment. But in the hands of Paublo the casting of the net became a scene worthy the brush of an artist. The object was to toss the folded net so that it would radiate over the school; and to accomplish this he spread it out in some way over his left arm, holding a portion of the edge between his teeth and the coil of cord in one hand. In this position, crouching, moving step by step, stealthily, toward the school, he reached a casting distance, perhaps eight or ten feet, then would stop, give a slight swing to the left, a long turn to the right, and with all his force launch the net into the air ahead of him. At once it assumed a circular shape, dropping upon the school, the lead weights sinking it to the bottom, holding the mullets in its toils. He now approached and began a series of twitches upon the cord, which imparted a like movement to the radiating cords, which presently hauled the sinkers together, completely enclosing the fish 
in a purse or bag, in which the entire catch was easily lifted and hauled ashore.

The mullet, Mugil cephalus, is the most important bait fish in the Gulf region and is found with another species, the silver-mullet, Mugil curema, in vast numbers from the lower Florida keys northward, - Biscayne Bay and Key, Indian River, and the Gulf states all having their quota, caught in seines and cast-nets at the various points alongshore. The average mullet weighs about half a pound to a pound, adults reaching seven, eight, or even twelve pounds, according to fishermen.

Fishes of various kinds constitute the common bait of the Florida region, but on the outer reef crayfish and conch were equally important. Before the singular destruction of the coral at Tortugas, some years ago, nearly every branch and head was the home of one or more crayfish, pronounced "craw," on the reef, really the spiny lobster, Palinurus. They dug out the sand so that their tails could be inserted, and backed in, leaving their whips or antennæ to wave to and fro. It was an easy matter to grain them. The grains was a two-pronged barbed spear not unlike a fish's tail in shape, with a long, yellow 
pine handle. By going out upon the lagoon or inner reef by sunrise the crayfish could be caught, as at this time they came in and spread over the reef, feeding upon the various kinds of algæ. So plentiful were they at times, that a boat could almost have been filled if necessary. This was the most killing bait on the reef except for bonito, barracuda, and jack of various kinds. Another bait used for red snapper and grouper was conch, Strombus gigas, the rich pink-lipped shell so common in collections. These could be found crawling over the lagoon in vast numbers, "hitching" themselves along by their sword-shaped operculum. The Conchtown of Key West in early days took its name from the Bahamians and others, who, it was supposed, lived more or less upon conchs, a diet as tough as unpounded abalone. The method of taking conchs was to pole the boat along, a negro accompanying it, who jumped overboard and threw the conchs in as fast as they were sighted. They were opened with a hatchet by cutting around the small end of the shell, upon which the animal could be unscrewed. Owing to its toughness this bait was in high esteem among the professional fishermen. 


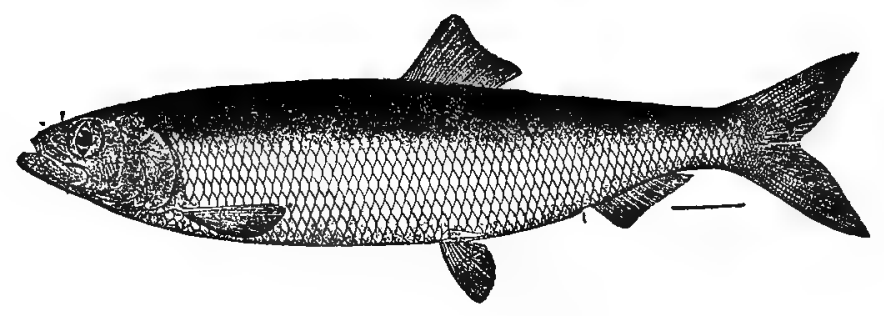

CALIFORNIA HERRING

Clupea pallasi

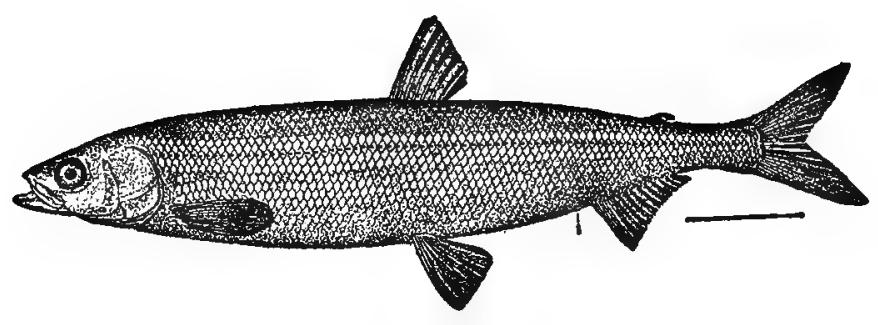

SURF SMELT

Hypomesus pretiosus 

Mullet is the popular bait for tarpon and a killing lure for almost any fish which preys upon its kind. At Fernandina, Florida, fiddlercrab is a valued bait, and I often drew on the preserves on the way to the fort, where there was always an endless supply, the struggling crab being a dainty that drum, sheepshead, channel-bass, or sea-trout rarely refuse. At Aransas Pass, shrimp, taken with a fine-mesh cast-net, is a favorite bait for channel-bass, Spanish mackerel, and others.

In New England clam bait, both hard and soft, is popular, and the title "high-tide clam-digger" was a term of derision applied by an old beachcomber of my fishing acquaintance to indicate the stupidity of a "tenderfoot." Menhaden is excellent bait for various fishes in this region. In the Chesapeake crabs are so plentiful that they are often used, the common edible crab preferred, and various shellfish.

In California waters baits of several kinds are used. Many fishermen use the meat of the beautiful shell abalone, Haliotis, which is tough and eaten only after being vigorously pounded. The California crayfish, Palinurus, ranks next, and is a killing lure, but already it is so rare 
on account of over-fishing, that it is an expensive bait. At the islands, for trolling, the principal baits for yellowtail are the California herring, Clupea pallasii, and the California smelt, Atherinopsis californiensis, - the latter preferred on account of its firmness. The California flying-fish, Exocotus californiensis, is the only bait in vogue for the tuna. It is caught in gill-nets, and numbers are frequently found in early morning in the fleet of fishing-boats and upon the beaches where they have "sailed" to escape the midnight raids of tuna and white seabass. The flying-fish is migratory, arriving at Santa Catalina in April, - sometimes earlier, sometimes later, - spawning in Avalon Bay in May and June. In July I have found the young half an inch long. They resemble grasshoppers in their attempts to "fly," hopping from the water six or eight inches with fins extended, and remaining on the surface like the gar. All reports to the contrary, the flying-fish does not fly. When alarmed it whirls its tail about like a screw, which drives it from the water with great force. The convulsive motion of the tail extends up the body toward the head, imparting to it a wriggling motion, which in turn imparts to the "wings," 
fins, a tremulous or flapping motion, at the same time they are "flapped" in an attempt to aid the fish in getting out of the water; but the moment the fish clears the water the fins are fixed and do not move; they are mere supporters, the fish being an animated parachute, or aëroplane. The only motion the winglike fins have is a fluttering of the edges when the wind is strong and ahead. The pectorals may be said to be locked; so are the ventrals, which also present a wide surface and aid in bearing up the fish. The latter moves until its inertia is exhausted, then the tail drops until it touches the surface, whereupon it is whirled furiously about again, forcing the fish into the air; and in this way it can travel for a fourth of a mile, then falling heavily with a crash, not entering the water head first. The fish has a very limited power of changing its direction. I have repeatedly had them pass over my boat, have been struck, and have seen them strike others; have watched the fish in passing a few inches from my face, and have waved my hat at it, all of which had no effect upon its movements or the direction in which it was soaring. From a large steamer I marked the course of flying-fishes as they rose, and several struck it. 
The flying-fish is an excellent bait for yellowtail or white sea-bass, as well as tuna. Along the California mainland, wharf fishermen fish for small fry, using clams and the various crustaceans found along the beaches, the natural food for "surf fishes." Squid, if it could be obtained, would be excellent bait for tuna, as in July I have found the stomachs of tunas filled with squid; and as they stop biting very suddenly, it is due possibly to the fact that they change their diet.

The various fishing-grounds for the great oceanic fishes of this country are so well known that it is hardly necessary to refer to them, but for the convenience of the angler they may in a very broad sense be divided into three classes: the region from Maine to Georgia, including the striped bass, bluefish, blackfish, sheepshead, drum, etc.; the Gulf region, including the snappers, barracuda, jewfish, groupers, kingfish, channel-bass, hogfish, black grouper, etc.; and the California region, including the yellowtail, white sea-bass, black sea-bass, albacore, tuna, California sheepshead, and California barracuda. Fishing-grounds for the first mentioned are found on various parts of the New England coast. The islands south of the Cape 

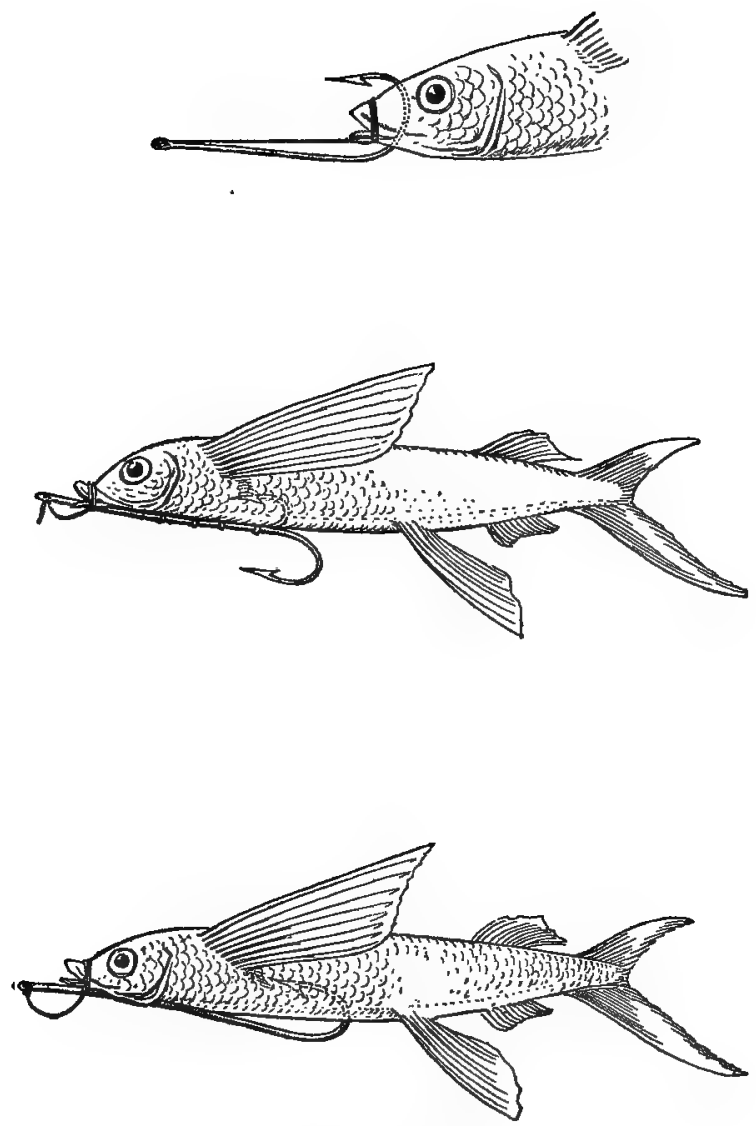

BAITED HOOKS 
- Martha's Vineyard, Nantucket, and others are all famous, especially Cuttyhunk and others, many being preserves for striped-bass fishing. At Fisher's Island, off New London, I have found excellent fishing for blackfish and bluefish. Block Island and vicinity is a famous fishing-ground. In the vicinity of New York the various grounds are well known, and professional fishermen can be found all alongshore from Hell Gate to Fort Hamilton, and on the Jersey coast; while in the summer daily steamers take ardent anglers to the fishing-banks. Old Point Comfort and vicinity is a prolific ground, and at all the seaports - Beaufort, Charleston, Savannah, and Fernandina - the angler will find more or less excellent fishing for sheepshead, drum, and "sea-trout." At Fernandina, in the mouth of the river, channel-bass and sea-trout are found, and I have had good sport at the mouth of the St. Johns with channelbass and sea-trout, not to speak of exhilarating shark-fishing. Pilottown is on the north side; Mayport on the south, reached by boat from Fernandina or from Jacksonville; or a pleasant trip is by small boat from Fernandina on the "inside." From here south the fishing increases, and the angler can now reach extreme Southern Florida 
by rail and find palatial hotels alongshore affording creature comforts, a marked contrast to the conditions which existed twenty-five years ago, when Southern Florida was comparatively unknown and the angler reached St. Augustine from the St. Johns River by an uncertain mule route, making his way to the Indian River as best he could. The latter is one of the most interesting and fertile regions in America for certain fishes, channel-bass, crevally, snapper, bluefish, sheepshead, sea-trout (Cynoscion), mangrove or gray snapper, Spanish mackerel, and sawfish. It is now readily reached by rail from New York via Jacksonville and St. Augustine. It is not a river, but a stretch of salt water one hundred and thirty-five miles in extent, separated from the ocean by a low sandy beach, and ranges in width from a few feet, at Jupiter Narrows, to six miles at Titusville. It is a shallow lagoon, with a depth of from three to seventeen feet. It has several inlets connecting it with the ocean, as Haulover Channel, Indian River Inlet, Fort Pierce Channel, Baker Cut, and Garfield Cut. There are several rivers running into it, as Gallie Creek, Sebastian, St. Lucia, and Jupiter.

The bottom of this "river" is in the main hard 


\section{Bait and Grounds}

and sandy, with some sandstone and coquina, well covered with algæ, - an ideal place for fish and fishing. The temperature of the water in January ranges from $59^{\circ}$ to $65^{\circ}$. Along the Indian River are a number of places, headquarters for the professional fishermen, where the angler may obtain information as to boats, boatmen, etc. Some of these are Eden, Titusville, Eau Gallie, Cocoa, Melbourne, Sebastian, Fort Pierce, Jensen, and Stuart, all in Brevard County and on the line of the Jacksonville and Indian River Railroad. Titusville, with a population of about one thousand, is the principal town. Following down the coast we come to Biscayne Bay and its many keys, and from here the angler may make his way down the reef and find a most interesting country at Key West and the keys and channels to the north and west. Key West has a large fishing fleet. The Tortugas group can be reached by chartering a smack, or by the government vessel. The winters here are delightful, but in the long summer the angler may expect intense heat and mosquitoes, - this pest not comparing, however, with that of the Florida mainland shores and rivers in the hot months.

The fishing localities of the west coast of Florida, 
more or less famous for tarpon, are well known, and include Tampa, Cedar Keys, St. James City, Charlotte Harbor, White Water Bay, Captiva Pass, Homosassa, Punta Rassa, and others - all reached via the railroad from Jacksonville. Other resorts on the north Gulf coast may be found at Pensacola and Mississippi Sound. The tarpon country of the coast of Texas is reached via New Orleans from the east and San Antonio from the west, and from Galveston to Aransas Pass fine fishing is to be had. The country calls to mind the Indian River region, being protected from the sea by a long sandy ridge. The town of Tarpon is situated on Aransas Pass, reached by the Aransas Pass Railroad to Rockport, where the mail boat may be taken to Tarpon, or to Sport, the headquarters of the Tarpon Club of Texas. The climate at the Pass is excellent in summer, insect pests are absent, and continuous breezes from the Gulf make the angling particularly enjoyable.

The fishing at Galveston is worthy of special mention. Here we find the Galveston Tarpon Club, whose members have fine sport with tarpon, jack, Spanish mackerel, and redfish. G. E. Mann, Esq., president of the club, writes to the Forest and Stream as follows, which, as I have 


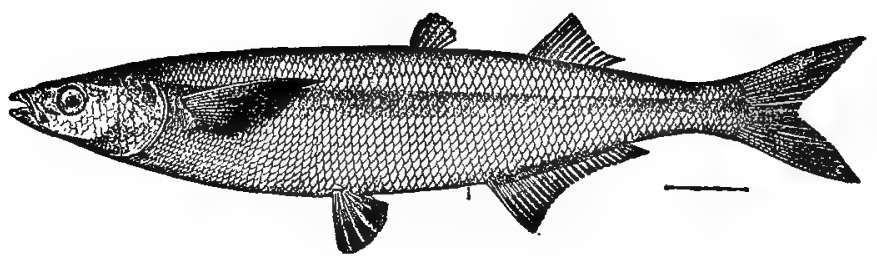

CALIFORNIA SMELT

Atherinopsis californiensis

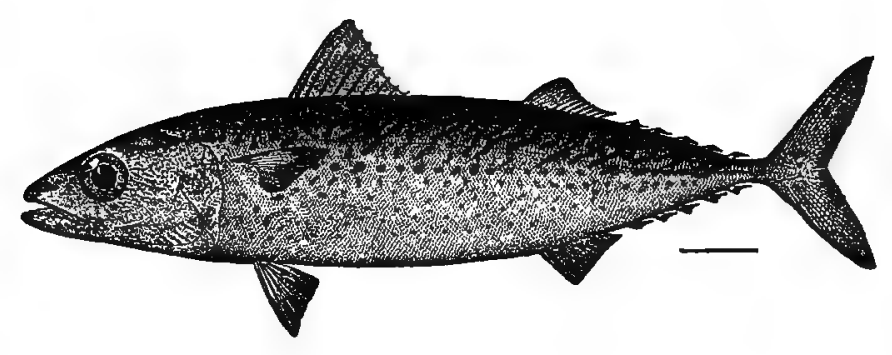

BULL'S EYE, OR CHUB MACKEREL

Scomber colias 

never visited the grounds, I take the liberty to copy :-

"There is many a man who, if he knew of it, would be glad to come a thousand miles to wrestle with a jackfish or shark or tarpon, standing on a granite rock six miles out in the Gulf of Mexico.

"It is strange that so few fishermen know of the fishing we have at Galveston. There is no other place in America that deep-sea fishing can be had for the rod and reel from a comfortable footing on a flat rock, many of the rocks from six to eight feet square, and so adjacent that you can follow along for a hundred yards if you wish. The jetties are some nine miles from the wharves, just far enough to keep out the pot-fishers, yet within an hour's run for a good launch. The Tarpon Club is small and has only one boat, but it is a fine seaworthy launch, carrying a dozen fishermen. It leaves for the jetties every day at one o'clock when the weather is suitable for fishing, and nearly every day some of the members go at four o'clock in the morning and get back in time to do a day's work. We have an enthusiastic set of fishermen who are always glad to welcome the stranger within our gates, who is of 
the rod and reel craft, and to give the best advantages we can for fishing."

The coast of Louisiana abounds in localities where the tarpon and other fishes can be taken; New Orleans having many ardent anglers who are devoted to the rod and reel.

Los Angeles is the central point for anglers going to the fishing resorts of Southern California. The tuna grounds are at Santa Catalina Island, twenty-five miles offshore, reached from San Pedro, twenty miles by rail from Los Angeles, by the Southern Pacific, Salt Lake railroads, and an electric road, there being from one to three steamers daily in summer and one in winter. Avalon, the port of Santa Catalina, is three and one-half hours from Los Angeles and has a summer population of five or six thousand and about fifteen hundred in winter. Hotels, cottages, boarding-houses, and numerous professional boatmen make this the best-equipped angling resort in the country, comfort being considered, there being no hot weather, mosquitoes, or pests of any kind, winter or summer, and that essential for tuna-fishing, - smooth water.

San Clemente Island, twenty-two miles distant to the southwest, can be reached by chartered 


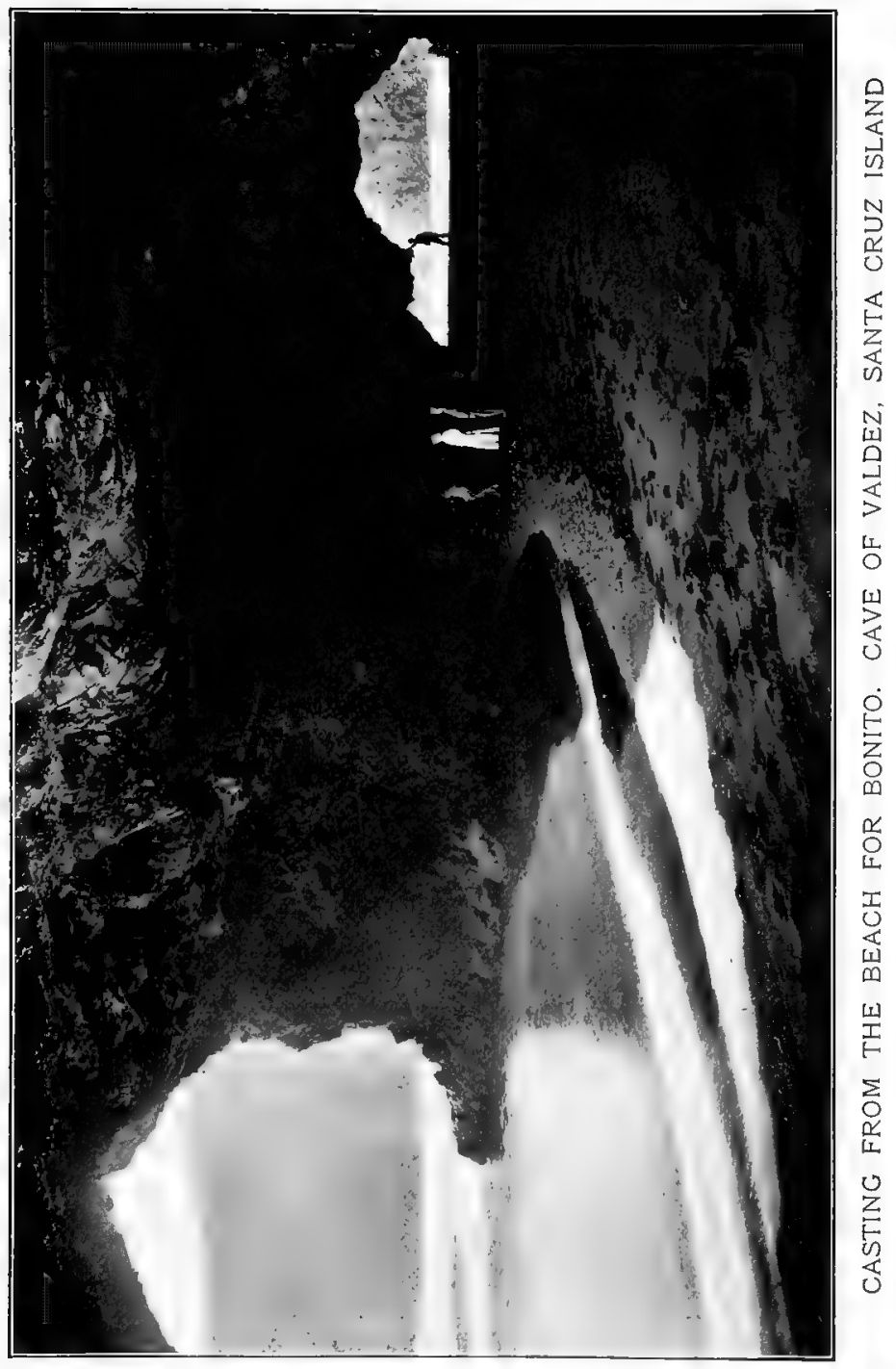



boat. It is government property and rented to sheep herders, and permission must be obtained to camp. The fishing is identical with all the island resorts, only better, if we except the tuna. Yachts can be chartered at Santa Catalina or San Pedro for the trip to the islands of Anacapa, Santa Rosa, Santa Cruz, San Miguel, and San Nicolas, or one can go from Santa Barbara. All are private property, and there are no towns and no regular connecting boats. Larco, a Santa Barbara professional fisherman, takes parties to the islands, which are large, picturesque, and beautiful. The only comfortable way to make this trip is to charter a commodious vessel, using her as a base of supplies, and cruise about the islands. Permission must be obtained to go ashore. Professional fishermen will be found at San Pedro, Long Beach, Redondo, Santa Monica, Newport, Laguna, Coronado, and San Diego, who take anglers out into the channel for large fish. San Diego is reached from Los Angeles by the Atchison, Topeka, and Santa Fé Railroad, and by a line of steamers from San Francisco, stopping at Santa Barbara, San Pedro, and Redondo. The coast line of the Southern Pacific will take the angler to San Luis Obispo, where 
bass and other fishes are to be had, while at Monterey and Santa Cruz in the summer great schools of salmon are found. Along the coast of Oregon and Washington are many charming fishing regions and gamy fish, which if the great halibut is excepted, which is always caught offshore, do not come within the scope of this volume. 


\section{INDEX}

Abalone, shell, as bait, 4I 3 .

Abeona minima, shiners, 186.

AEtobatus, eagle ray, 405.

Albacore [Germo alalunga] -

Fishing for, 200-209.

Food, 201.

Game qualities, 201.

Range, 20r.

Season, 202.

Strength, 205.

Tackle, 202.

Value, 2 IO.

Amber-jack [Seriola lalandi] 149. Angel-fishes -

Black, 355-356.

Family, 354.

Yellow, 356-358.

Angling, see Sea-angling.

Anisotremus surinamensis, pompon, 404.

Antony and Cleopatra story, 296.

Aransas Pass -

Jewfish sport, 304.

Shark fishing, $37^{2}$.

Spanish mackerel fishing, 290.

Tarpon, 253, 256, 261.

Archosargus probatocephalus, see Sheepshead.

Arion, dolphin story, 347 .

Atherinopsis californiensis as bait, 4I4.

Atlantic, tuna range, Kingsley on, 54 . Avalon -

Angling resort, 422.

Sea-lion catch, 279.
Bait -

Barracuda of Florida, 91, 92, 96.

Blackfish, 276.

Black sea-bass, I10, 116.

California baits, 414 .

Clam bait, 4I3.

Collection of bait, 408-4I r.

Conch as bait, 412 .

Crayfish as bait, 411 .

Drum, 318.

Fiddler-crab as bait, 413 .

Flying-fish as bait, 4I4-4I6.

Gray snapper, 36, 37, 43 .

Groupers, 213, 220.

Hogfish, 118.

Jack, 173.

Kingfish, 283, 288.

Mullet as bait, 4I I.

Sheepshead, 327, 329.

Shell abalone as bait, 413 .

Shrimp as bait, $4 \mathrm{I} 3$.

Tarpon, 237, 253 .

Tuna, 59, 63, 414, 416.

Varieties of bait, 41 1-416.

White sea-bass, 20, 26, 27, 28.

Yellowtail, 140, 414.

Bait-taker, 408.

Barracuda of California [Sphyrana argentea] -

Fishing for, 99-102.

Food, 103.

Habitat, 103.

Spawn, 104.

Tackle, 102.

Weight, I02. 
Barracuda of Florida [Sphyrana barracuda $]$ -

Bait, 9I, 92, 96.

Curiosity, 91.

Description, 89.

Ferocity, 88, 90, 98.

Fishing methods and experiences, $91-96$.

Flushing, 92.

Food, value as, 97.

Game qualities, 88.

Giants, 98.

Habits, 98.

Range, 89.

Spawning, 90.

Tackle, 94.

Young, 95.

Bass -

Channel-bass, see that title.

Sea-bass, see that title.

Striped bass sport, 277 .

Bastard halibut [Paralichthys californicus ] 369.

Black angel-fish [Pomacanthus arcuatus] 355-356.

Blackfish [Centropristes striatus] 277.

Blackfish [ Tautoga onitis] -

Bait, 276.

"Chowder fish," 276.

Fishing, 276-280.

Food, value as, $275-276$.

Range, 274, 276.

Spawning, 276.

Weight, 276.

Black grouper [Garrupa nigrita] 216-221.

Black sea-bass [Stereolepis gigas] -

Bait, I 10, 116.

Color, I06.

Fishing for, 106-II5.

Game qualities, II5.

Haunts, 105, 106, 108.

Length, I06, 107.
Black sea-bass [continued] -

Season, 108.

Species, 108.

Tackle, I I5, I 16, I I7.

Towed by, II 2.

Weight, 108, rog.

Bluefish [Pomatomus saltatyix] -

Description, $\mathbf{1}_{58} 8$.

Family, 158.

Fishing for, $\mathbf{1}_{53}-\mathbf{1} 58$.

Food, value as, 162 .

Game qualities, 156.

Migration, 159, 16r.

Number, 160.

Range, 159, 16r.

Rod record, I57.

Spawning, I6I.

Synonyms of, 152 .

Tackle, 155 .

Voracity, I60.

Weight, 157 .

Blue parrot-fish [Scarus coruleus] 338.

Boatmen, see names Long John, etc.

Boats -

"Bull Pup" sloop, 323, 334.

Tuna fishing, 59.

Yellowtail fishing, I40.

Bonito [Sarda chiliensis] -

Beauty, 294.

Range, 295.

Season, 295.

Sport, 294.

Bottle-nose dolphin catch, 348 .

"Bull Pup" sloop, 323, 334.

Butterfiy-fish [Lampris luna] 348.

Butterfly-fishes, name for mariposas, 355.

Byron, dislike for angling, 268 .

Calamus kendalli, pluma, 404.

California, Gulf of, white sea-bass habitat, 30 . 
California barracuda, see Barracuda of California.

California crayfish as bait, 4I3.

California flying-fish as bait, 4I4.

California herring as bait, 4I4.

California sheepshead [ Pimelometo-

Coloring, 177 .

$$
\text { pon pulcher] - }
$$

Description, $176-178$.

Fishing for, $181-183$.

Food, value as, 183 .

Game qualities, 182 .

Range, I76, I 79, I80.

Tackle, I8I.

Weight, 183 .

California smelt as bait, 414 .

Caranx hippos, see Jack.

Caranx pisquetus, hard-tailed jack, 173.

Caulolatilus princeps, whitefish, 183 .

Centropomus, robalo, I3I.

Centropomus undesimalis, found on Texan coast, I $3 \mathbf{I}$.

Centropristes striatus, sea-bass, 277.

Chance in sea-angling, 14.

Channel-bass [Scianops ocellatus] -

Description, 187, 193, 194.

Fishing for, 191-193.

Food, value as, 199 .

Game qualities, 198.

Names, 189.

Range, 188, 190, 198.

Size, 195.

Spawn, 199.

Surf-fishing, 196.

Tackle, I9I.

Value, 199.

Cherna criolla grouper, 221.

Chief, grouper fishing, 216.

Chinook of Monterey [Oncorhynchus tschawytscha] -

Fly-fishing, $384-386$.

Habits, $3^{87}, 396$.

Kipling's fishing experiences, 385 .
Chinook of Monterey [continued] Season, 388.

Sport, 388, 390-395.

Tackle, 388-390.

Whitney, J. P., study and writings, $385,386,389,39 \mathrm{I}$, 394 .

Chatodipterus faber, see Mariposas.

"Chowder fish," blackfish, 276.

Clam bait, 4I3.

Cleopatra and Antony story, 296.

Clupea pallasii as bait, 4I4.

Colonies, fishes of, see Hawaiian Is]ands and Porto Rico.

Conch as bait, $4 \mathbf{r} 2$.

Coryphanicia, see Dolphin.

Crayfish as bait, 4II, 4I3.

Cuban hogfish, 128.

Cynoscion macdonaldi, species of white sea-bass, 30.

Cynoscion nobilis, see White sea-bass.

Cynoscion parvipinnis, species of white sea-bass, 32 .

Deep-sea fishes and water pressure, I I-I 2.

Digestive organs of game fishes, 8 .

Dog snapper [Lutianus jocu] 45.

Dolphin [Coryphanida] -

Beauty of, 345 .

Bottle-nose dolphin, 348 .

Color changes, 346 .

Description, 345-348.

Fishing, 342-347

Game qualities, 13, 345 .

Range, 343 .

Size, 346.

Species, 348.

Tackle, 344 .

"Don Juan," quotation from, 268.

Drum [Pogonias cromis] -

Bait, 318.

Description, 3 I I.

Drumming, 314. 
Drum [continued]-

Fishing, 31 7-323.

Food, 312.

Game qualities, 322.

Habits, 312.

Names, 312.

Range, 312, 314.

Scaling, 318.

Size, 311 .

Spawning, 3I3.

Tackle, 317.

Value, 323.

Eagle ray [AEtobatus] 405.

Eggs of game fishes, 9 .

Elliott, Hon. W., sheepshead sport, 327.

Epinephelus drummond-hayi, spotted grouper, 222.

Epinephelus morio, red grouper, $212-$ 215.

Evermann, B. W., fishes of Porto Rico, 40I.

Eye movement of halibut, 370 .

Feast of the kingfish, 288.

Fiddler-crab as bait, $4 \mathrm{I} 3$.

Fishes, see Game fishes.

Fishing grounds, 416-424.

[See also names of places.]

Florida barracuda, see Barracuda of Florida.

Florida fishing grounds, 417 .

Florida jewfish, see Jewfish.

Florida reef -

Bait, kinds of, 4 II .

Drum fishing, 318.

Groupers, 212.

Grunt, 315.

Mariposas, 350.

Shark fishing, 372 .

Snapper sport, 33-49.

Tarpon fishing, 224.

Flying-fish as bait, 414-416.
Forests, submarine, 105, I78-180, 351.

Framework of game fishes, I- 5 .

Frenchman, tarpon fishing anecdote, 266.

Gaffing -

Kingfish, 284.

Tarpon, 264.

Tuna, 79.

Galeorhinus, tiger shark, 375 .

Galveston, fishing resort, 420.

Game fishes of United States -

Albacore, see that title.

Angel-fishes, see that title.

Angling, see Sea-angling.

Barracuda of California, see that title.

Barracuda of Florida, see that title.

Blackfish, see that title.

Black sea-bass, see that title.

Bluefish, see that title.

Bonito, see that titte.

California sheepshead, see that title.

Channel-bass, see that title.

Chinook of Monterey, see that title.

Colonies, fishes of, see Hawaiian Islands and Porto Rico.

Cooking, 296.

Deep-sea fishes, II-1 2.

Dolphin, see that title.

Drum, see that title.

Eggs, 9.

Fishing grounds, 416-424.

Florida jewfish, see Jewfish.

Gray snapper, see that title.

Groupers, see that tille.

Grunts, see that title.

Habits, II.

Halibut, see that title.

Hawaiian Islands, see that title. 


\section{Index}

Game fishes of United States [continued] -

Hogfish, see that title.

Jack, see that title.

Jewfish, see that title.

Kingfish, see that title.

Literature, pp. viii-x.

Mariposas, see that title.

Opha, 348.

Phosphorescence, 12.

Pollack fishing, 277 .

Porto Rico, see that title.

Pressure of deep water, 12.

Reproductive methods, 9, II.

Robalo, r31.

Rock-bass, 186.

Scientific investigation by specialists, p. vii.

Sea-angling, see that title.

Sharks, see that title.

Sheepshead, see that title.

Shiners, 186.

Snappers, see that title.

Sockdolliger, definition, halibut fishing, 360-364.

Spanish mackerel, see that title.

Spawning, 9-II.

Structure -

Deep-sea fishes and the pressure of water, 12 .

Digestive organs, 8.

Framework, 1-5.

Illuminating organs, 12.

Internal parts, 6-9.

Locomotive organs, 3-5.

Scales, 9.

Tarpon, see that title.

Triple-tail, 332.

Tuna, see that title.

Varieties in many seas, 279-280.

Vocal abilities, 315-317.

Whitefish, 183 .

White sea-bass, see that title.

Yellowtail, see that title.
Garden Key -

Gray snapper resort, 34, 45.

Spanish mackerel, 290.

Gardner, boatman, tuna fishing, 79.

Garrupa nigrita, black grouper, 216-22I.

George, N. M., tarpon catch, 240.

Georgia, sheepshead range, 329.

Germo alalunga, see Albacore.

Gilbert, Dr. C. H., identification of Luvarus imperialis, 398.

Gilthead, ancient cultivation, 324 .

Golden angel-fish, name for yellow angel-fish, 357 .

Gray snapper [Lutianus griseus] -

Appearance, 35 .

Bait, $36,37,43$.

Cunning, $4 \mathrm{r}$.

Fishing method, 39, 40.

Florida reef sport, 33 .

Game qualities, 42.

Haunts, 44, 45 .

Migration, 44 .

Night fishing, 48.

Range, 44.

Species, 45 .

Weight, 43, 44.

Young, 44.

Green snapper [Lutianus analis] 47.

Groupers [Serranida] -

Black, 216-22I.

Red, 212-2I 5 .

Sport, tackle, etc., 2I 2-222.

Spotted, 222.

White, 22 r.

Grunts -

Florida reef, 315.

Porto Rican waters, 402-403.

Gulf of California, white sea-bass habitat, 30.

Gulf of Mexico, barracuda fishing, 88.

Gulf Stream, dolphin fishing, 342347 . 
Halibut [Hippoglossus hippoglossus] -

Bastard halibut sport, 366-369.

Eye movement, 370 .

Fishing, 357-368.

Game qualities, 360 .

Hook used by Indians, 365 .

Size, 364 .

Sockdolliger, 360-364.

Sport in Southern California waters, 278.

Strenuous sport, $365-366$.

Tackle, 365,366 .

Weight, 364,365 .

Young, 370 .

Haliotis as bait, $4^{1} 3$.

Hamlet grouper, 221.

Hammerhead, fighting and strength, 377-382.

Hard-tailed jack, caranx pisquetus, 173.

Hawaiian Islands -

Angling in, 397.

Luvarus imperialis specimen, 398.

Parrot-fishes, 339 .

Herring, California, as bait, 4I4.

Hippoglossus hippoglossus, see Halibut.

Hamulon, common grunt of Florida reef, 315 .

Hofe, E. vom, tarpon catch, 240.

Hogfish [Lachnolaimus maxi-

Bait, I 18. mus] -

Cuban, 128.

Deep-water forms, 127, 129.

Description, 122-127.

Fishing for, 122-132.

Food, 129, 130.

Game qualities, 124.

Haunts, 119, 128.

Migration, 129.

Monument to, 128.
Hogfish [continued'] -

Names, 127.

Poison, 128.

Species, 127.

Tackle, I23.

Holacanthus ciliaris, yellow angelfish, 356-358.

Holder, C. F., leaping tuna, 58.

Holder, Dr. J. B., tuna specimens, 53,54 .

Horse mackerel, name for tuna, 54.

Howe, Dr. H. W. -

Gun camera, 373 .

Tarpon fishing, 240, $27 \mathrm{r}$.

Illuminating organs of game fishes, 12.

Indian River, fishing resort, 418.

Jack [Caranx hippos] -

Bait, 173.

"Beat," 164, I70.

Description, 172.

Feeding, 167 .

Fishing for, 164-1 73 .

Game qualities, 169,172 .

Haunts, 163, I71, 177.

Names, 170.

Porto Rican caranx, 400.

Spawning, I7I.

Species, 173.

Synonyms, 170.

Tackle, 168.

Texan, I 2 .

Weight, I 1 I.

Jenkins, W. S., tarpon migration, 230.

Jewfish [Promicrops] -

Fight with, 305 .

Fishing experiences, 298-303.

Genera, 304.

Kedging, 300 .

Range, 304, 307-308.

Record, 305. 
Jewfish [continued] -

Run of, 304 .

Season, 306.

Sewing mouth, 303 .

Size, 302, 305.

Spawning, 306.

Status, 298.

Stories of, 299.

Tackle, 303, 306.

Texan, 304 .

Weight, 305 .

Jordan, Dr. -

Chinook fly-fishing, 384 .

Samoa and Hawaiian Islands, fishing in, 397.

Jovius, Bishop Paul, fish story, 309.

Key West, fishing resort, 419.

Kingfish [Scomberomorus regalis] -

Bait, 283, 388.

Beauty of, 285 .

Feast of, 288.

Fishing, 282-285.

Gaffing, 284.

Game qualities, 283 .

Giant, 287 .

Leaps of, 283 .

Size, 286, 287 .

Tackle, 282.

Value, 287 .

Kingfish, second [Scomberomorus cavalla] 286.

Kingsley, Atlantic range of the tuna, 54 .

Kipling, Rudyard, chinook fishing, 385 .

Lachnolaimus maximus, see Hogfish.

Lampris luna, opha, 348.

Leaping sharks, see Sharks.

Leaping tuna, see Tuna.

Lobotes surinamensis, triple-tail, 332.

Locomotive organs of game fishes, 3-5.
" Long John," commander of the "Bull Pup," 323, 334, 341, 353.

Loro, blue parrot-fish, 338 .

Louisiana fishing grounds, 422.

Luminous fishes, 12 .

Lutianidla, see Snappers.

Lutianus analis, green snapper, 47.

Lutianus apodus, schoolmaster, 50 .

Lutianus aya, red snapper, 45 .

Lutianus griseus, see Gray snapper.

Lutianus jocu, dog snapper, 45 .

Luvarus imperialis, Hawaiian specimen, 398.

Mackerel -

Salt mackerel of Marc Antony, 296.

Spanish mackerel, see that title.

McLellan, I., poem, I69.

Mann, G. E., fishing at Galveston, 420.

Marc Antony and Cleopatra story, 296.

Mariposas [Chcetodipterus faber] -

Family, 354.

Fishing, 35I.

Game qualities, 354 .

Range, 353.

Size, 353 .

Tackle, $351,352$.

Mexico, tarpon fishing, 271, 272.

Mexico, Gulf of, barracuda fishing, 88.

Monterey chinook, see Chinook of Monterey.

Mugil cephalus as bait, 41 I, 4I3.

Mugil curema as bait, $4 \mathrm{II}$.

Mullet as bait, 4III, 4I3.

Nassau grouper, 221.

Oceanic fishes, see Game fishes.

Oceanic fishing, see Sea-angling. 
Old Point Cornfort, sheepshead fishing, 326, 327, 329.

Oncorhynchus tscharoytscha, see Chinook of Monterey.

Opha [Lampris luna] 348.

Orata, S., gilthead cultivation, 324 .

Palinurus as bait, 4I3.

Paralichthys californicus, bastard

Parrot-fishes -

$$
\text { halibut, } 369 \text {. }
$$

Blue parrot-fish, 338 .

Description, 336, 337 .

Fishing, 333-338.

Hawailan esteem, 339 .

Poisonous, 339.

Pseudoscarus guacamaia, 339.

Pascagoula and its music, legend,

Paublo 316.

Bait collecting, 408-410.

Gray snapper fishing, 38 .

Jewfish sport, 300 .

Kingfish sport, 282-285.

Siesta while fishing, 406 .

Phosphorescence of game fishes, 12.

Photographing tarpon in air, 373.

Pimelometopon pulcher, see California sheepshead.

Pluma [Calamus kendalli] 404.

Pogonias cromis, see Drum.

Pollack fishing, 277.

Pomacanthus arcuatus, black angelfish, 355-356.

Pomatomus saltatrix, see Bluefish.

Pompon [Anisotrenıus surinamensis] 404.

Porgies in Porto Rican waters, 404.

Porto Rico, game fishes -

Conditions of fishing, 399.

Eagle ray, 405.

Evermann's report, 401.

Fishes in Porto Rican waters, 400-407.
Porto Rico, game fishes [continued] -

Grunts, 402-403.

Pluma, 404.

Pompon, 404 .

Tarpon, 40I -402 .

Promicrops, see Jewfish.

Pseudoscarus guacamaia, parrot-fish, 339.

Rays, Porto Rican waters, 405.

Red grouper [Epinephelus morio] 2I 2-215.

Red snapper [Lutianus aya] 45 .

Red tail [Lutianus synagris] 50.

Reproduction of game fishes, methods, 9 , II.

"Rip-raps," triple-tail specimen, 332.

Robalo [Centropomus] I3I.

Rock-bass of California waters, 186.

Rod-fishing, 12-13.

Rods for sheepshead fishing, 328 .

[See also Tackle.]

Salmon, chinook, see Chinook of Monterey.

Salt mackerel of Marc Antony, 296.

Samoa, game fishing, 397.

San Clemente Island, fishing, 422.

San Jorgas Bay, white sea-bass fishing, 30-3I.

Santa Catalina -

Fishing resort, 422.

Halibut sport, 366 .

Tiger sharks, 375 .

Tuna fishing, 57 .

White sea-bass catch, 18.

Santa Cruz, famous for salmon, 395.

Sarda chiliensis, see Bonito.

Scales of game fishes, 9 .

Scarus, name for blackfish, 275, 276.

Scarus corruleus, blue parrot-fish, 338.

Schoolmaster (Lutianus apodus) 50. 
Scianops ocellatus, see Channel- Sharks, 371-382.

bass.

Scomberomorus cavalla, second kingfish, 286.

Scomberomerus maculatus, see Spanish mackerel.

Scomberomorus regalis, see Kingfish.

Scombrida, see Tuna.

Sea-angling -

Artful discernment of fish, I7.

Bait, see that title.

Boats, see that title.

Byron, dislike for angling, 268.

Chance, element of, 14 .

Courtesy code, tarpon angling, 276.

Fishing grounds, 416-424.

Gaffing, see that title.

Modern pastime, p. v.

Nature, anglers' love of, I 18.

Rod-fishing, I 2-13.

Season, 215 .

Stories of ill-luck, 18.

Superstitions of sea-anglers, I4.

Tackle, see that title.

Trolling, see that tille.

Varieties in many seas, 279280.

[See also Game fishes.]

Sea-bass [Centropristes striatus] 277.

Black sea-bass, see that title.

Species, 277.

White sea-bass, see that title.

Sea-drum, see Drum.

Sea fishes, see Game fishes.

Sea-lion catch, 279.

Second kingfish [Scomberomorus cavalla] 286.

Seriola, see Yellowtail.

Seriola dorsalis, Pacific species of yellowtail, I45.

Seriola lalandi, amber-jack, I49.

Serranida, see Groupers.
Hammerhead fishing experience, $377-382$.

Sport, 372-382.

Tiger shark, 375 .

Sheepshead [Archosargus probatocephalnes] -

Ancient cultivation, 324 .

Bait, 327, 328, 329.

Description, 325.

Family, 325.

Fishing, 328-332.

Habits, 325 .

Range, 326, 327, 329.

Rods, 328 .

Size, 329, 330.

Spawning, 330.

Tackle, 328, 33 .

Value, 324 .

Sheepshead, Californian, see California sheepshead.

Shell abalone as bait, 413 .

Shiners [Abeona minima] 186.

Shrimp as bait, 413.

Silver mullet as bait, 4 I I.

Skeleton of game fishes, I-5.

Smelt, California, as bait, 414.

Snappers [Lutianide] -

Characteristics of family, 49.

Dog snapper, 45 .

Florida sport, 33-49.

Gray snapper, see that title.

Green snapper, 47.

Red snapper, 45.

Red tail, 50.

Schoolmaster, 50.

"Sockdolliger," definition, halibut fishing, $360-364$.

Spanish mackerel [Scomberomorus maculatus ] -

Aransas Pass, 290.

Beauty, golden glint of fish, 292, 293.

Fishing, 289-292. 
Spanish mackerel [continued] Garden Key, 290.

Migration, 292.

Range, 292.

Spawning, 292.

Tackle, 29 .

Spawning of game fishes, 9-Ir.

Spotted cero, name for kingfish, 286.

Spotted grouper [Epinephelus drummond-hayi] 222.

Sphyrana argentea, see Barracuda of California.

Sphyrana barracuda, see Barracuda of Florida.

Squid, tuna bait, 416 .

Stereolepis gigas, see Black sea-bass.

Striped bass sport, 277 .

Strombus gigas as bait, 412.

Structure of game fishes, sec Game fishes.

Submarine forests, 105, 178-180, 35 I.

Superstitions of sea-anglers, 14 .

Surf-fishing for channel-bass, 196.

Tackle -

Albacore, 202.

Barracuda of California, I02.

Barracuda of Florida, 94.

Black sea-bass, II 5, II6, 117 .

Bluefish, 155 .

California sheepshead, 181.

Channel-bass, I9r.

Chinook of Monterey, 388-39o.

Dolphin, 344.

Drum, 317.

Groupers, 212.

Halibut, 365,366 .

Hogfish, 123.

Jack, 168.

Jewfish, 303, 306.

Kingfish, 282.

Leaping tuna, 59-67.
Tackle [continued] -

Mariposas, 35r, 352.

Sheepshead, 328, 331.

Spanish mackerel, 29 r.

Tarpon, 236, 237, 257-26r.

White sea-bass, 24, 25.

Yellowtail, 139.

Tamisio, maigre fish story, 309 .

Tampico, tarpon fishing, $271,272$.

Tautog, name for blackfish, 274 .

Tautoga onitis, see Blackfish.

Tarpon [Tarpon atlanticus] -

Aransas Pass, 253, 256, 26 I.

Bait, 237, 253.

Courtesy code in angling, 270.

Description, 227, 228.

Fighting, 255.

First view of the tarpon, 223.

Fishing, 224-270.

Frenchman anecdote, 266.

Gaffing, 264.

Game qualities, 226.

Habits, 233 .

Jenkins, W. S., on, 230.

Leap of, 239, 247, 248, 251, 272.

Mexican fishing, 271, 272.

Migration, 230.

Name, 228.

Photographing in air, 373 .

Playing, 264, 265.

Porto Rican waters, 40I-402.

Pumping, 264.

Range, 229.

Rapacity, 233.

Records, 240, 24I, 252.

Scales, 233.

Season, 234 .

Size, 233.

Skill required in tarpon fishing, 266.

Smallest, 23r.

Spawning, 232.

Tackle, 236, 237, 257-26r.

Texas, 23I, 244-246. 
Tarpon [continued] -

Trolling, 253, 263.

Weight, 255.

Winter fishing, 271.

"Yucatan Bill," 373, 374.

Tarpon atlanticus, see Tarpon.

Texan Jack, 172.

Texas, tarpon fishing, 231, 244-246.

Tiger shark [Galeorhinus] 375 .

Triple-tail [Lobotes surinamensis] 332.

Trolling -

California barracuda, 99, 102.

Tarpon, 253, 263.

Tuna [Scombrida] -

Bait, 59, 63, 414, 416.

Boats, 59 .

Breeding, 85 .

Charge of, 73 .

Exciting experience, 79.

Feeding, 5 I, 69, 7x.

Fighting abilities, 75-78.

Fishing for, $59-82$.

Gaffing, 79.

Game qualities, 77.

Giants, $55,78$.

Hooking, 2.

Leap of, 72, 83 .

Migration, 67 .

Play of, 73, 77 .

Record, 58, 66, 77 .

Size, 53 .

Tackle, 59-67.

Weight, 53 .

Vocal abilities of fishes, 315-317.

Waddell, J. A. L., tarpon fishing at Tampico, 271.

West Indies, hogfish range, 128.

Whitefish [Caulolatilus princeps] 183 .
White grouper [Epinephelus striatus] 221 .

White sea-bass [Cynoscion macdonaldi $] 30$.

White sea-bass [Cynoscion nobilis] -

Appearance, 22-23.

Bait, 20, 26, 27, 28.

Food, value as, 29.

Habitat, 18, 21, 23, 26, 30 .

Habits, 29, 30.

Length, 22.

Santa Catalina catch, 18.

Species, 23, 30, 32.

Tackle, 24, 25 .

Weight, 22, 23, 24, 28, 30 .

Young, 29, 33.

White sea-bass [Cynoscion parvipinnis] 32.

Whitney, J. P., chinook fishing, $3^{85}$, $386,389,391,394$.

Winter, tarpon fishing, $27 \mathrm{I}$.

Xenocrates, scarus, 275.

Yellow angel-fish [Holacanthus citiaris] 356-358.

Yellowtail [Seriola] -

Bait, 140, 414.

Description, I44.

Fishing for, 133-148.

Food, 147 .

Haunts, 138 .

Inshore, I38.

Relations, 144.

Rush of, 134 .

Spawning, 145 .

Species, 145, I49.

Tackle, 139.

Tameness, 147 .

Value, 146.

"Yucatan Bill," 373, 374. 



\section{AMERICAN SPORTSMAN'S LIBRARY}

\section{The Water-fowl Family}

By Leonard C. SANFord, L. B. Bishor, and T. S. VAN Dyke. Illustrated by L. A. Fuertes, A. B. Frost, and C. L. Bull.

\section{Bass, Pike, Perch, and Pickerel}

By James A. Henshall, M.D. Illustrated by Martin Justice and others.

\section{IN PREPARATION FOR EARLY ISSUE}

\section{Big Game Fishes of the United States}

By Charles F. Holder. Illustrated by Charles F. W. Mielatz and others.

\section{Guns, Ammunition, and Tackle}

By A. W. Money, W. E. Carlin, A. L. A. Himmelweight, and J. HarRINGTON KEENE. Illustrated.

\section{The Bison, Musk=ox, Sheep, and Goat} Family

By George Bird Grinnell, Owen Wister, and Caspar Whitney, Illustrated by CARL RUNGIUS and others.

\section{Photography for the Sportsman Naturalist}

By W. E. Carlin. Illustrated.

Further volumes will include articles on The Bear Family; The Cougar, Wild Cat, Wolf, and Fox; The Sporting Dog; American Race Horse and Running Horse; Trotting and Pacing; Riding and Driving; Yachting, Small Boat Sailing, and Canoeing; Baseball and Football; Rowing, Track Athletics, and Swimming; Lacrosse, Lawn Tennis, Wrestling, Racquets, Squash, and Court Tennis; Skating, Hockey, Ice Yachting, Coasting, and Skate Sailing.

\section{THE MACMILLAN COMPANY}

66 FIFTH AVENUE, NEW YORK 


\title{
AMERICAN SPORTSMAN'S LIBRARY
}

\author{
Edited by CASPAR WHITNEY \\ Crown 8vo. Cloth. Each \$2.00 net
}

\section{The Deer Family}

By Theodore Roosevelt, T. S. Van Dyke, D. G. Elliot, and A. J. Stone. Illustrated by CARL Rungius; with map by Dr. C. HART MerRIAM.

"The illustrations by Carl Rungius are excellent and appropriate, and the entire contents of the book bear evidence of having been written by men who have a loving and educated interest in their subjects."

- New York Evening Post.

\section{Upland Game Birds}

By Edwyn Sandys and T. S. Van Dyke. Illustrated by L. A. Fuertes,

A. B. Frost, J. O. Nugent, and C. L. Buld.

"It is a creditable work, written with care and intelligence, and will be found very entertaining by those who pursue feathered game. There is a good deal of instruction to be found in the work, which is likely to add considerably to the success of the sportsman when hunting the birds described."

- Shooting and Fishing.

\section{Salmon and Trout}

By Dean Sage, W. C. Harris, and C. H. Townsend. Illustrated by A. B. Frost and others.

"A distinctly valuable and authoritative contribution.... Will be found to contain interesting material and reliable information for the enthusiastic fisherman, who would know how, when, and where to fish for these gamy denizens of our lakes and streams."

- The Fishing Gazette.

\section{THE MACMILLAN COMPANY}







